ASIAN BORDERLANDS

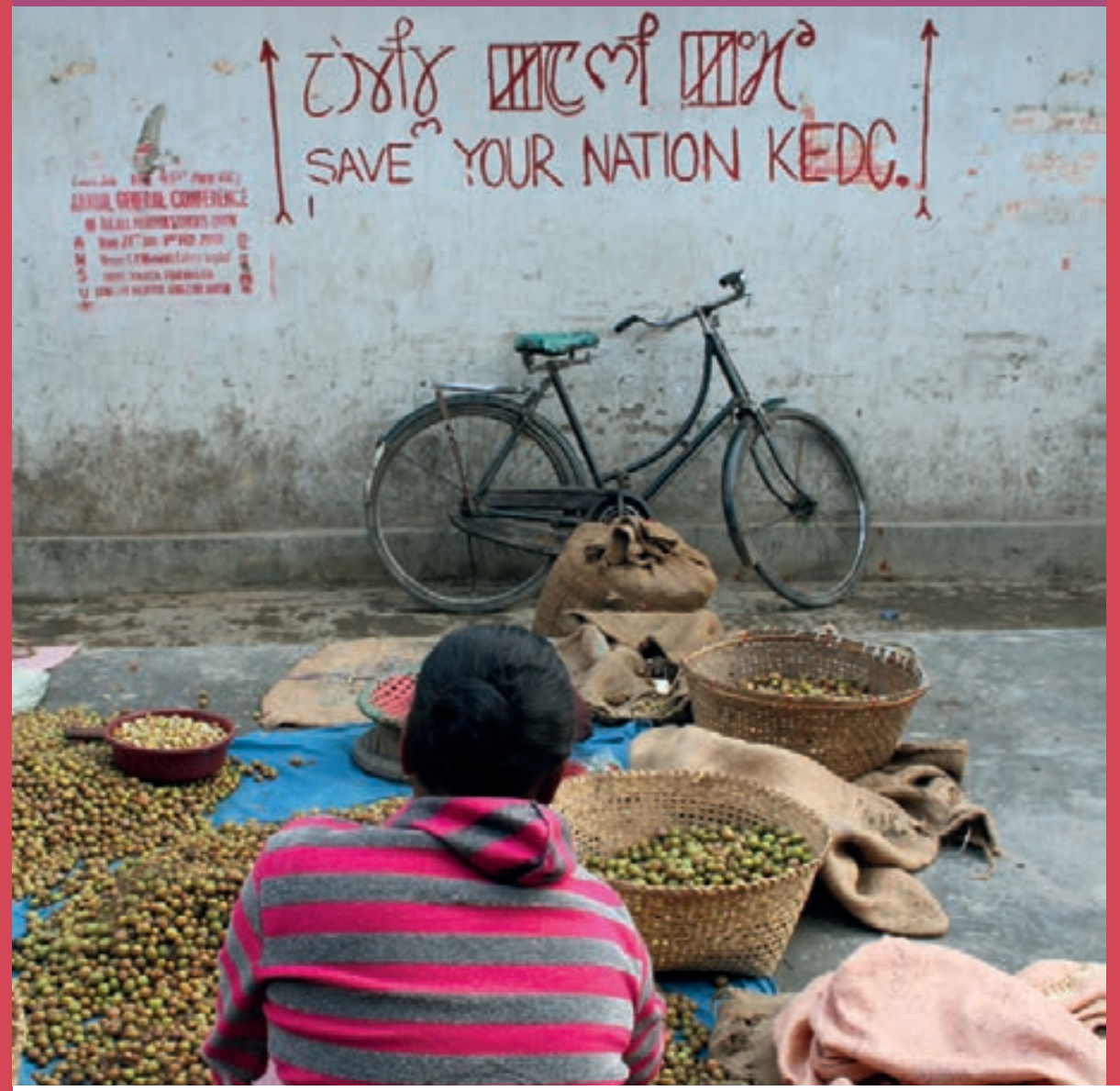

Duncan McDuie-Ra

\title{
Borderland City in New India
}

Frontier to Gateway 
Borderland City in New India 


\section{Asian Borderlands}

Asian Borderlands presents the latest research on borderlands in Asia as well as on the borderlands of Asia - the regions linking Asia with Africa, Europe and Oceania. Its approach is broad: it covers the entire range of the social sciences and humanities. The series explores the social, cultural, geographic, economic and historical dimensions of border-making by states, local communities and flows of goods, people and ideas. It considers territorial borderlands at various scales (national as well as supra- and sub-national) and in various forms (land borders, maritime borders), but also presents research on social borderlands resulting from border-making that may not be territorially fixed, for example linguistic or diasporic communities.

\section{Series Editors}

Willem van Schendel, University of Amsterdam

Tina Harris, University of Amsterdam

Editorial Board Members

Franck Billé, University of Cambridge

Eric Tagliacozzo, Cornell University

Yuk Wah Chan, City University Hong Kong

Duncan McDuie-Ra, University of New South Wales 


\section{Borderland City in New India}

Frontier to Gateway

Duncan McDuie-Ra 
Cover illustration: Khwairamband Bazaar, Imphal. Photo: author.

Cover design: Coördesign, Leiden

Layout: Crius Group, Hulshout

Amsterdam University Press English-language titles are distributed in the US and Canada by the University of Chicago Press.

$\begin{array}{ll}\text { ISBN } & 978 \text { 90 } 89647580 \\ \text { e-ISBN } & 97890485^{2} 53^{6} 2 \text { (pdf) } \\ \text { DOI } & 10.5117 / 9789089647580 \\ \text { NUR } & 740\end{array}$

(C) Duncan McDuie-Ra / Amsterdam University Press B.V., Amsterdam 2016

All rights reserved. Without limiting the rights under copyright reserved above, no part of this book may be reproduced, stored in or introduced into a retrieval system, or transmitted, in any form or by any means (electronic, mechanical, photocopying, recording or otherwise) without the written permission of both the copyright owner and the author of the book.

Every effort has been made to obtain permission to use all copyrighted illustrations reproduced in this book. Nonetheless, whosoever believes to have rights to this material is advised to contact the publisher. 
Dedicated to the journalists of Manipur 
Map 1.1 Manipur and surrounding states and territories

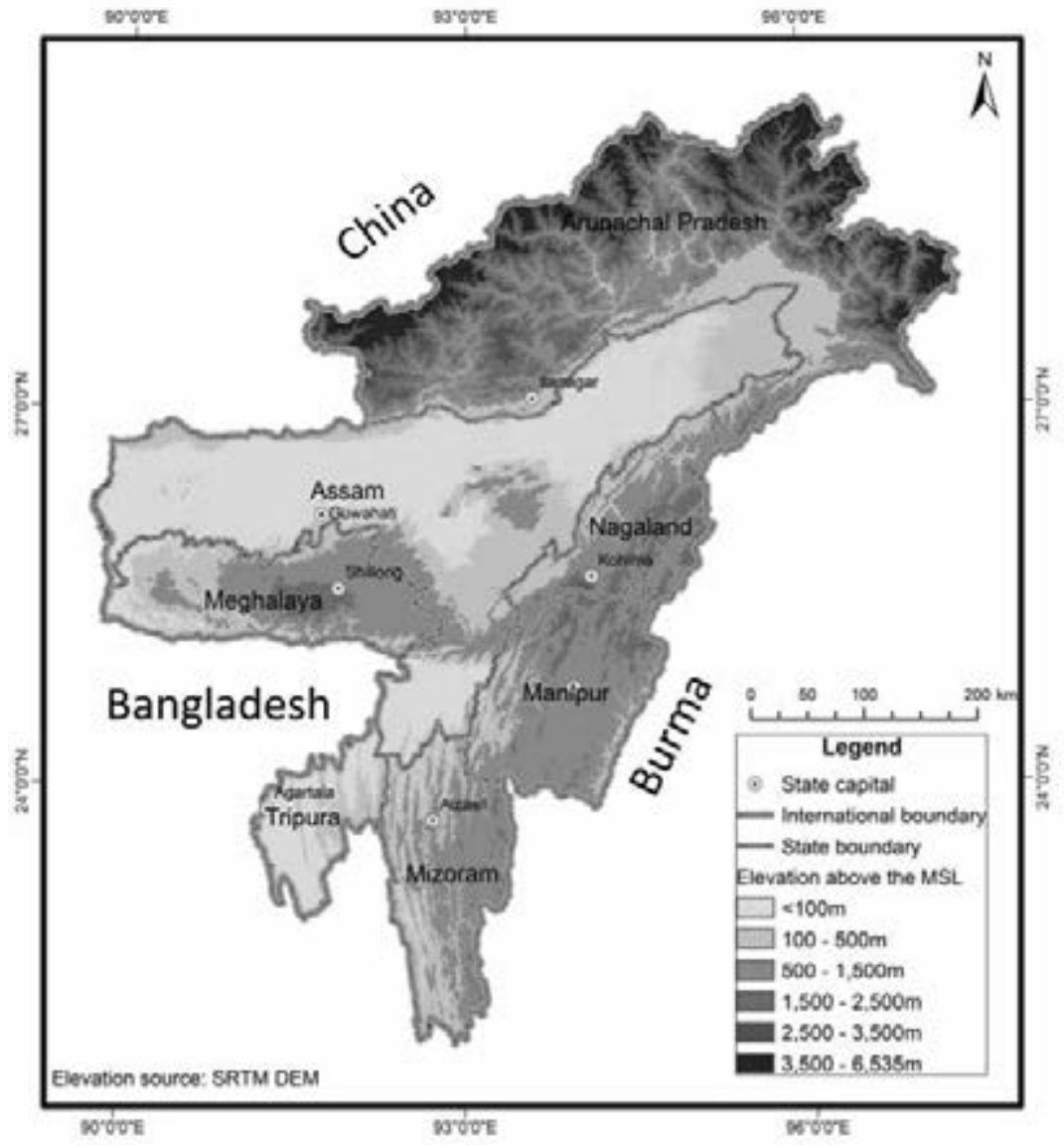

Source: Sarat Phukan 


\section{Table of Contents}

List of Maps and Images

Acknowledgments

1 Introduction 13

$\begin{array}{lr}\text { Disturbed City, Sensitive Space } & 17\end{array}$

$\begin{array}{ll}\text { Frontiers to Corridors } & 23\end{array}$

$\begin{array}{ll}\text { Approaching Imphal } & 27\end{array}$

$\begin{array}{ll}\text { Structure of the Book } & 31\end{array}$

Terminology and Place Names 33

\section{Part 1 Disturbed City, Sensitive Space}

2 Belonging 39

Small City, Growing City $\quad 43$

Plurality and Polarity $\quad 47$

Neighbourhoods $\quad 50$

Alternative Places $\quad 57$

$\begin{array}{ll}\text { Conclusion } & 63\end{array}$

3 Control $\quad 65$

Spatial Control in Imphal $\quad 67$

$\begin{array}{ll}\text { The Armed Forces } & 67\end{array}$

$\begin{array}{ll}\text { Civilian Government } & 73\end{array}$

$\begin{array}{ll}\text { Non-state Actors } & 78\end{array}$

$\begin{array}{ll}\text { Contesting and Co-opting Memory } & 79\end{array}$

$\begin{array}{ll}\text { Resistance and Nationalism } & 81\end{array}$

Insurgent Memorials $\quad 85$

$\begin{array}{lr}\text { Conclusion } & 89\end{array}$

4 Exclusion $\quad 93$

$\begin{array}{lr}\text { Ethnic Politics } & 95\end{array}$

Mao Gate $\quad 96$

$\begin{array}{lr}\text { Sadar Hills } & 98\end{array}$

Belonging and the Blockades $\quad 100$ 
Indigenous Politics

\section{Part 2 Liberalising the Frontier}

5 Gateway City 119

New India and Its Frontier 122

Indigenising Indian Capital $\quad 129$

Gateway Livelihoods $\quad 133$

Closing the Gate $\quad 138$

Conclusion 144

6 Health City 145

Building a Health City 146

The Decaying Public System 152

Accidental Liberalisation? $\quad 153$

Reshaping the Urban Frontier $\quad 156$

$\begin{array}{ll}\text { Conclusion } & 160\end{array}$

7 Education City 163

$\begin{array}{lr}\text { Sangaiprou } & 166\end{array}$

$\begin{array}{lr}\text { Schools versus Paddy } & 171\end{array}$

Recruiting in Imphal 174

$\begin{array}{lr}\text { Conclusion } & 179\end{array}$

8 Conclusion 183

$\begin{array}{lr}\text { Acronyms } & 189\end{array}$

$\begin{array}{ll}\text { Glossary of Non-English Terms } & 191\end{array}$

$\begin{array}{lc}\text { References } & 193\end{array}$

$\begin{array}{ll}\text { Index } & 205\end{array}$ 


\section{List of Maps and Images}

Map 1.1 Manipur and surrounding states and territories

Image 1.1 Shanker Talkies, Lamphelpat $\quad 17$

Image 2.1 Central Imphal facing north 44

Image 2.2 Multi-storey houses alongside partially completed houses, Uripok Khumanthem Leikai $\quad 56$

Image 2.3 Manhunt billboard, LIC Point 61

Image 3.1 State Police at Thangal Bazaar 69

Image 3.2 Bir Tikendrajit Flyover with the Ima Keithel behind 75

$\begin{array}{ll}\text { Image 3.3 PLA Memorial at Cheiraoching } & 87\end{array}$

Image 4.1 Advertisement for $23^{\text {rd }}$ Century, Salam Leikai 94

Image 5.1 Billboard featuring Mary Kom, Khoyathong 120

Image 5.2 Local clothes shop, New Checkon 135

$\begin{array}{ll}\text { Image 6.1 Shija Hospital, Langol } & 149\end{array}$

Image 6.2 Baptist church under construction, Langol 159

Image 7.1 School under construction, Sangaiprou $\quad 168$

Image 7.2 Advertisement for a secondary school, DM campus $\quad{ }_{176}$

Image 8.1 Start of the rally, Haobam Marak Lourembam Leikai $\quad 185$

All images by the author 



\section{Acknowledgments}

This book would simply not have been possible without the knowledge, kindness and patience of Thingnam Anjulika Samom and Sobapathi Samom. I am forever indebted to both of you. Thank you to everyone in Imphal who shared their lives with me, gave me directions to a place I was pronouncing poorly, and offered me bora (and ui). I hope I have found suitable pseudonyms for you all! Thank you to the Ukhrul contingent for helping me clear my head and get out of the city when it got to be too much. Thank you also to Yengkhom Jilangamba and Parismita Singh for opening my eyes to new ways of looking at things and answering many questions. And, as always, thanks to Dolly Kikon and Xonzoi Barbora for making sure I didn't forget what is important. Thank you to the following people who commented on the idea as it developed and encouraged me to explore it: Jason Cons and Willem van Schendel. Thank you also to: Michael Eilenberg, Christian Lund, Nancy Lee Peluso, members of the Skagen School, Tina Harris, Julian Zipparo, Zali Fung, Maggie Yie-Quach, Liani Tlau, Marc Williams, Selina Th., John Rees, James Arvanitakis, Kalervo Gulson, Shabazz Palaces, RTJ2, Willie Isz, Billy Woods, YC the Cynic, Paul Millsap, Kyle Korver, Al Horford and Jeff Teague - who all helped in various ways. Finally, thank you to Yoo-Kyong and Kimeri for making life so interesting and enjoyable.

Research that appears in Chapter 6 was funded in part by the Australian Research Council (LP120100108). 



\section{$1 \quad$ Introduction}

On the far eastern edge of India, just 100 kilometres by road from Myanmar, is Imphal, the capital of Manipur; a former kingdom controversially merged into the Indian Union in 1949 and subject to various separatist and interethnic conflicts ever since. With a population of half a million, Imphal city sits in the Imphal valley, a depression within the Patkai range at an elevation of 770 meters surrounded by higher, steeper hills that form the majority of the land in the state. Among the semi-completed residential buildings, military check posts and headquarters, government buildings sitting behind security bunkers, and markets teeming with goods from across the border are the remains of Imphal's cinema halls. On Bir Tikendrajit Road, one the Imphal's busiest streets, sits Rupmahal - a theatre built in 1948 and the onetime heart of Imphal's politically charged theatre scene (see Somorendra, 200o) and later a cinema. Like so many other patches of pavement along Bir Tikendrajit Road, including the nearby public library, the courtyard of Rupmahal hosts a second-hand clothes market. Vendors have strung bamboo poles hanging shirts and coats between concrete pillars, exterior walls, and on protruding steel rods. On plastic sheets arranged on the ground are piles of pants and T-shirts. The clothes have labels and logos in Chinese, Korean and Thai. Inside the dark lobby of the theatre is an old ticket window for Imphal Talkies, the cinema that ran from of Rupmahal for several decades (and now the name of one Manipur's best-known rock bands). The cinema has not operated since the early 2000 s when underground groups imposed a ban on Hindi language in Manipur, reducing the number of films available to show. This, combined with mounting insecurity for residents since the 1990s, killed off Imphal nightlife (Akoijam, 2010). The place appears deserted but behind the heavy door of the theatre is a troupe of actors rehearsing for an afternoon performance under a few light bulbs dangling from the roof. The cinema is gone, but in its place the theatre has been resurrected.

Around the city the scene is repeated. At Friends' Mini cinema in Paona Bazaar the grand stairway that would have once led up into a mezzanine foyer is lined with small shops, built on improvised timber platforms balanced on the stairs and propped up with cinder blocks, selling new clothes that have come from the border markets. In the upper foyer four men are playing table tennis by the entrance to the main cinema hall in the complex. One of them agrees to open up the locked door for me. All of the seats have been removed and the floor is taken up by orderly rows of second-hand clothing in bales under the soaring ceiling. The pink and 
sky-blue stucco ceiling remains, though it has faded. Light comes instead from bulbs dangling from rope tied the length of the hall and through large holes in the wall where air vents have been removed to let in shards of sunlight (and pigeons). One of the caretakers explains that they look after stock for several merchants in the surrounding area. Every now and again the merchants send porters to carry off a bale from their massive inventory, all of which are marked with a name and a number hand-written on the side.

Perhaps most poignant of all the old cinemas is Shanker Talkies in Lamphelpat, a locality in the west of the city. In a yellow and red cube building dating from the late 1970s, Shanker Talkies too has a once-grand walkway complete with scenes from the Khamba-Thoibi, a Manipuri folktale, above the landings and the long-disused kiosk. Old film posters peel off the walls and debris gathers on the marble floor. Shanker Talkies was built as a twin theatre and the larger theatre is still used occasionally for premiere screenings of Manipuri films - a thriving industry also aided by the decline in Hindi cinema - though following their premiere local films are mostly shown in smaller video halls and in people's homes on laptops and DVD players. When I visited Shanker Talkies the door to the smaller theatre was open. Inside it was dark - the only light coming through removed sections of wall near the ceiling. On the stage was a drum-kit and microphones. In the aisles a man paced up and down rehearsing a sermon. Others walked back and forth praying. A young man, Chao-toiba, approached and welcomed me to the Spirit of Faith Church Imphal, an evangelical sect for recent Meitei converts to Christianity running services in the old cinema for want of a permanent space. He asked that I stay for their service, stressing that I would enjoy listening to their pastor who was trained in Ukhrul - a hill area right on the border with Myanmar.

Afterwards in the vacant lot outside where shops once stood selling food and locally made shoes and clothes to cinema patrons, and where playing cards and small brown medicine bottles now lay scattered on the ground, Shanker Talkies stood against the bright midday sky as a tempting metaphor for Manipur's recent history. The ban on Hindi language had helped the decline of cinemas in Imphal. Chronic insecurity and high levels of violence certainly played a role as well. Ironically, the ban on Hindi was enforced and planned by Meitei ethno-nationalist groups in a bid to preserve Meitei language and culture. Yet a decade and a half later within an old cinema run-down by the ban, a group of Meiteis were running an evangelical church welcoming new converts to Christianity: Indian cultural domination may have been prevented but other 'external' influences were certainly visible in social life. Indeed if the end of Hindi cinema suggests a 
kind of closing off of Manipur to India in the 2000s, a turning away, then the influx of second-hand clothes that now fill the very same buildings originating from East Asia, perhaps via other stops, suggests an opening to the rest of Asia - all played out on the urban landscape. Yet among all this direction changing Rupmahal is still staging Manipuri plays, suggesting perhaps that indigenous culture can persevere in the midst of these larger dynamics. Of course the metaphor is partial, just one thread in a complex story. But a compelling thread nonetheless.

Imphal was classified 'disturbed' by the Indian Government from 19802004. Imphal's residents have been subject to the excesses of extraordinary laws and military occupation, incoming flows of refugees, separatist insurgencies and armed extortion, and mostly unsuccessful attempts at economic development. The city exemplifies what Dunn and Cons call a sensitive space, where people are subject to multiple 'interwoven projects, logics, goals and anxieties of rule operating at once' (2014: 102). Despite decades of violence, extraordinary laws, poor employment prospects, and civic dysfunction, Imphal continues to grow. Migrants arrive from rural Manipur, from neighbouring border polities, from across the borders with Bangladesh and Myanmar, and - controversially - from other parts of India and Nepal. At the same time a large Manipuri diaspora has formed, sending back remittances to relatives and later returning to settle in Imphal.

This book is an exploration of belonging, exclusion, and agency in Imphal at a time when prevailing configurations of power in the city, honed through decades of extraordinary laws and dysfunctional civilian politics, are being met by the forces of capital let loose by the transformation of the borderland from a frontier to a corridor. My argument has two parts. First, I argue that within the city authority is fragmented into microsites of contention where state, quasi-state (military and paramilitary) and non-state actors seek to control space. This situation evokes Lund's notion of fragmented sovereignty, namely that in 'post-colonial political landscapes, governance is not the preserve of governments. A wider variety of institutional actors are at play in this enterprise, often using the language and idioms of state' (2011: 887). Everyday acts by residents such as protest, creating memorials, marking territory, and the demarcation of neighbourhoods challenge the spatial practices of those in control, or seemingly in control. These acts are attempts to make place, to establish and maintain a sense of belonging. However, I posit that belonging also entails exclusion of others, and in Imphal this takes place along two main fault lines: between ethnic communities and between Manipuris and migrants from outside the state. Imphal is the battleground upon which these claims for place are fought. 
I am interested in how these battles play out in, and also shape, the urban landscape itself. As discussed further below, the conceptual framework of sensitive space (Dunn and Cons, 2014) and fragmented sovereignty (Lund, 2011) - approached with cognisance of Lefebvre's (1991) dialectical approach to the production of space - illuminates the ways Imphal is controlled and the ways this control is challenged from below by people in search of belonging and trying to make do. Making do, what Pine refers to as 'creative tactics for seizing opportunities and negotiating risk' (2012: 10), takes place in a city where the enablers of everyday life such as mobility, safety, security, property rights, cash loans, sanitation, and employment are promised and provided by various actors at various times in different parts of the city. So too are the threats to everyday life such violence, extortion, and evictions among others. This argument is explored in part one of the book.

Having established the contours of the frontier city and the ways residents navigate them, part two explores its nascent transformation into a gateway city. Not only is the borderland seen as a corridor to new markets, it is seen as a new market itself and subject to various policies aimed at maximising its 'potential'. The liberalisation of a militarised city long-dominated by a heavy state presence and security-driven governance brings forth my second main argument. Official discourse of the Indian Government and various policy analysts and think tanks envisages a future borderland where goods, people, and production move in and out of the gateway city. Yet connectivity operates very differently when viewed from below. Various organised and ad hoc actions exploit new mobilities and new vulnerabilities to make claims for recognition of Manipuri sovereignty, to challenge the ways space is controlled on the streets, and to make demands on the Manipur and Indian Governments for greater territorial autonomy - for example. I argue that while connectivity brings Imphal further under the control of the Indian state and opens the city to Indian and transnational capital - a sensitive development in a polity where resistance to India has underpinned political and economic life for the last sixty years - connectivity also provides new opportunities to advance claims for place, belonging, and territory.

Further, Imphal's booming private health and education sector are reshaping the landscape of the city. The so-called 'health city' and 'education city' are seemingly at odds with the picture of the city painted in part one; violent, dysfunctional, divided. However, in keeping with the second point of argument, they also demonstrate alternative imaginings of connectivity: the desire for local entrepreneurs engaged in licit and illicit livelihoods to invest in making Imphal a health hub for the borderland 
Image 1.1 Shanker Talkies, Lamphelpat

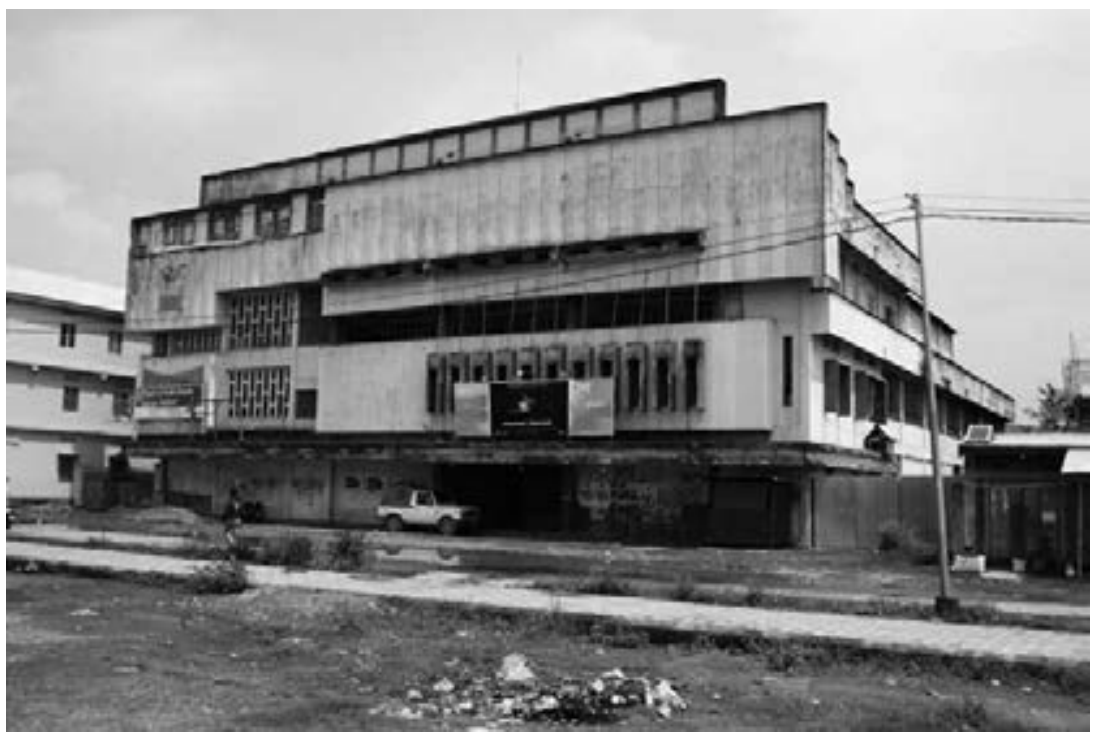

and the extraordinary demand for private education to enable further study in other parts of India and provide a ticket out. These booms have stretched the boundaries of the city generating new struggles over place in the peri-urban fringe. They are also examples of endogenous liberalisation that depend, in part, on the dysfunctional state apparatus and the power of non-state actors. In other words it is doubtful whether such a boom would be possible without the 'transgression and erosion' (Dunn and Cons, 2014: 104) of sovereign power that characterises life in Imphal; a situation likely found in other militarised borderlands with various degrees of similarity and difference. Finally, at least in the case of the health sector, endogenous liberalisation is an expression of self-sufficiency for a community with limited mechanisms to enact autonomy and for whom existing institutional structures have disappointed.

\section{Disturbed City, Sensitive Space}

Manipur is part of the subnational region known as Northeast India, an administrative term of the Indian Government applied to diverse geographic region consisting of eight federal states: Arunachal Pradesh, Assam, Manipur, Meghalaya, Mizoram, Nagaland, Sikkim and Tripura as well as 
a number of autonomous territories. With the exception of Sikkim all of these states have had at least some of their territory declared a 'disturbed area' in the last six decades. A disturbed area is any designated territory within the current (though disputed) borders of India where extraordinary laws can be enacted. Only the Ministry of Home Affairs or the Governor of the respective state can declare an area disturbed (Ministry of Home Affairs, 1958/1998, Section 3). In India the Governor is a non-elected position appointed by the President. In the Northeast the appointee is usually a former member of the military (Baruah, 2005). Designating an area as disturbed must be reviewed periodically every six months - yet there is no limit on the renewal of disturbed status, and some areas of the borderland have been declared disturbed continuously for decades. Once declared the designation is not open to judicial review and state and local governments can do little to challenge its imposition.

Disturbed status produces a disturbing reality. It enables the Armed Forces (Special Powers) Act $195^{8}$ (AFSPA) to operate. The AFSPA permits any member of the Indian Armed Forces and Paramilitary (armed forces hereafter) to fire 'even to the causing of death' upon individuals acting in contravention of any law or order, carrying weapons (or anything capable of being used as a weapon) or assembling in a group of five or more people. Under the AFSPA, suspected persons can be detained for 24 hours, with unlimited extensions/renewals, and members of the armed forces are permitted to enter any premises without a warrant; collapsing the distinction between public and private space. Most significantly, the AFSPA provides legal protection (in the form of both de facto and de jure impunity) for members of the armed forces operating in a disturbed area (Mathur, 2012).

Imphal was declared disturbed in 1980. Disturbed status was lifted from the Imphal valley, including Imphal city, in 2004 following mass protests after the rape and murder of a Manipuri woman, Thangjam Manorama Devi, by members of the Assam Rifles paramilitary, including a bold nude protest by members of the Meira Paibis women's association (Bora, 2010; Gaikwad, 2009; Misri, 2011). Yet the legacy of disturbed city status is powerful. A decade on the armed forces still occupy the city, still administer various public buildings, and still have a major influence on political and social life. Further, although the Manipur Government has its own police forces that are not legally bound by the AFSPA they operate within the same culture of impunity and are responsible for much of the contemporary violence in Imphal. As an indication of the scale of rights abuses under AFSPA, 1528 cases of 'fake encounter', the term used for the murder of a civilian by the military that is then justified by branding the deceased an insurgent, were 
currently awaiting hearing in the Supreme Court as of June 2014 (Imphal Free Press, 2014). A staggering number for a population of 2.6 million and keeping in mind that this figure represents only fake encounters, not rape, murder without fake encounter, and disappearances. This number only represents the incidents that have been filed as cases. Many relatives of those killed do not take cases forward over fear that they will face retribution, that other family members will be investigated, or because they simply have no faith that it will do any good.

Many of these killings took place before 2004, but there is little to indicate that levels of violence or insecurity have been significantly reduced by the lifting of disturbed status from the city, especially when it is still in place in other districts of the state and given the armed forces have not left the city. Further the Manipur police and various local security forces do not operate under the auspices of AFSPA, thus the lifting of disturbed status does little to affect their operations. Imphal may no longer be officially disturbed, yet life on the ground continues to be disturbing; subject to the same culture of violence and impunity that has characterised the city since the 1980s (McDuie-Ra, 2012b). Violence has become unremarkable over time, reflecting Sidaway's notion of 'banal geopolitics' (2001) wherein violence is framed as 'unexceptional' - if at all - in the face of on-going and oft-repeated arguments about the inviolability of Indian territorial sovereignty on the one hand and the savagery of anti-national rebellion on the other (see also Abraham, 2014).

The activities of the various underground groups further produce the disturbing reality of everyday life. Estimates of the number of underground groups operating in Manipur tend to hover in the 30 (SATP, 2014a; IDSA, 2014) though the propensity of state agencies and right-wing think tanks to use labels like 'terrorist' or 'insurgent' to describe underground groups can be misleading. Some groups are organised armed groups fighting for secession from India, for changes to existing federal state boundaries, for territorial autonomy within Manipur, and for changes to ethnically determined affirmative action categories. Many of these groups have 'above ground' political parties, media outlets, and affiliated NGOs that engage with the government and the military on various issues - usually outside formal politics. Some are distant offshoots or loose affiliates of these organised groups or have no relationship to them. Some are closer to organised crime networks that engage in illegal activities like smuggling, trafficking, kidnapping, and extortion but also in the murky world of Imphal's infrastructure development, contracting, racketeering, and - increasingly - social services. They are able to exercise control over certain spaces within the city and 
influence mobility, livelihoods, and security in negative and positive ways depending on circumstances. They protect as well as threaten, and for many residents this makes them very similar to the armed forces or the police.

The territorial politics of the three main ethnic groups in Manipur, vestiges of colonial anthropology and systems of rule: the valley-dwelling Meitei and hill-dwelling Naga and Kuki tribal communities exacerbate tensions in the city. Violent encounters between Naga and Kuki communities ruptured life in the hill areas through the 199os leading many of those affected, or simply scared, to flee to Imphal. In the 2000 s tensions between the Meitei community and both hill communities heightened the hostility of interethnic tensions, culminating in three epochal moments. First, the Meitei protests against the Naga ceasefire and possible redrawing of Manipur's boundaries in 2001 that led to security forces killing 18 Meitei protestors. Those killed were subsequently made martyrs and have a permanent memorial site in Imphal (Kekrupat) and an annual day of mourning - a constant reminder of the hill-valley tensions. Second, in late 2010 the Mao Gate incident provoked hostilities between Nagas in the hills and the Meitei community of the valley when the Manipur Government tried to block the leader of the National Socialist Council of Nagaland Isak-Muivah (NSCN-IM), the main Naga independence organisation, Thuingaleng Muivah, from entering the state. Nagas protested in the hills, blocking the highways into Imphal and cutting the city off for almost three months. Third, Kuki communities pushing for an autonomous hill district within Manipur staged a blockade of Imphal in 2011 that went for even longer. Life during the blockades is trying. Shortages, price hikes, closed schools, offices, shops, and deep community tensions keep many people off the streets.

In Imphal, the condition of living in a disturbed city has an undeniable legacy. Yet the disturbed city is more than a categorisation or description of a period. It is a metaphor for the ruptures to everyday life experienced in the borderland during the brutal chapters of state-making that have taken place prior to and following Indian Independence in 1947. Yet disturbed also gives a sense of continued affect: of a sub- or semi-conscious state of being and acting birthed in moments of rupture yet continuing long after (see Seigworth and Gregg, 2010).

Disturbed status and its attendant extraordinary laws raise the question of how such conditions can exist in the world's largest democracy? Agamben's (2005) reworking of Schmidt's state of exception has proved very attractive to scholars seeking to understand the existence and persistence of extraordinary laws in Manipur and other parts of the borderland 
(Basavapatna, 2012; Chakravarti, 2010; Gaikwad, 2009; Kshetrimayum, 2009; Sundar, 2011). Authors utilising Agamben to frame the Northeast - even in passing - argue that extraordinary laws have been able to function in the region for so long because the region itself is an exceptional zone, disloyal, unstable, and violent; where the exception to the law initially created under conditions of crisis has become the norm (Agamben, 1998:166). This appears to perfectly describe disturbed areas and the persistence of AFSPA. For example, in referring to AFSPA Vajpeyi writes that Manipur should 'not be thought of only as a zone of exception, but as a contradiction so extreme that it undoes the totality in which it is embedded, and breaks it down into distinct and mutually opposed regimes: a democracy and a non-democracy; two nations: India and not-India' (2009: 36). She goes on to argue 'if the AFSPA is the ban under which the sovereign power of the Indian state has placed all of the Northeast, then the exception to the rule of law that is spatialised in the Northeast should be thought of as a camp'. The camp being what Agamben calls 'the fundamental bio-political paradigm of the West' and where subject populations are stripped of their rights and agency (1998: 181). Agamben's concept of 'bare life' is also used to refer to people living under AFSPA; a population in a permanent state of exception without political or legal rights, or even subjectivity, at the whim of sovereign power (see Kshetrimayum, 2009; Gaikwad, 2009; Vajpeyi, 2009). Political agency is restrained, though when it does occur requires desperate and spectacular gestures, such as the naked protests by members of the Meira Paibis in Imphal in 2004, discussed in chapter 3, analysed brilliantly by Baishya (2010).

While seductive and certainly evocative, the popularity of Agamben for understanding the borderland, Manipur, and Imphal is not only becoming formulaic, it is redirecting scholarly enquiry away from the multiple forms of sovereign power that operate, the agency of different actors and individuals in the region, and the complex and ambiguous nature of citizenship in the borderland. Manipur is not a camp. This is not to say sovereign power cannot take away life with little or no consequences; this is true. And while evoking exceptionalism marks the gravity of abuses of sovereign power in Imphal by state and quasi-state actors, their power is not absolute, they are highly sensitive as to how they are portrayed, and they are engaged in contentious struggles to control of the city - some of which they lose. While I am not antithetical to the framing of Indian power in relation to its ethnic minority borderlands in this way myself, at least at a certain level (McDuie-Ra, 2009a, 2012a), such an approach calls forth a singular coherent sovereignty that is difficult to locate on the ground. Further it constructs 
Manipur as a passive space, a depoliticized landscape of misery with few agents or acts of defiance, let alone endogenous sources of power. It erases almost all of the complexity and contradiction of life in Manipur. Further it stops short of unravelling this complexity to see whether exceptionalism does indeed shape everyday life - a necessary task for ethnographers.

As Baishya argues with regard to the burgeoning use of Agamben in works on the Northeast borderland: 'By privileging the postcolonial state as the singular topos of sovereignty, and correspondingly, the overarching entity that spatialises the state of exception, commentators ... often downplay the fractured nature with which governmentality is wielded and its effects experienced or endured in the region ... [and] leads to a restricted vocabulary for understanding modes of sovereign governmentality, states of dispossession and its aftermaths' (2015: 6o6-607).

The state of exception gives an interesting starting point but reveals little of what constitutes social and political life within the borderland, and in the case here, in Imphal. Given the power of state, quasi-state, and non-state actors in controlling space in Imphal it is crucial to move beyond its limitations. It is here that the concept of 'sensitive space' developed by Dunn and Cons (2014) serves as a useful starting point for understanding power and belonging in Imphal. Sensitive spaces are notable 'for the multiple forms of power that abound, compete and overlap there and the forms of anxiety that they provoke for both those who are governed and those who seek to govern' (2014: 95). Anxiety is certainly characteristic of Imphal, where the desire for control by certain actors is often more identifiable than actual control of space.

The concept identifies multiple forms of power in contested spaces and the ways people navigate and challenge these in their everyday life (2014: 100-101). And in doing so people are 'constantly forced to transgress the bounds of projects, they erode specific sovereign projects - the techniques of sovereign power - and the claims to sovereign authority that they mark' (2014: 102). This constant erosion produces anxiety for actors seeking to govern sensitive space as it exposes their tenuous hold on territories they claim. Thus agency is not only about making do, but the ways that making do can expose the limits of control; especially when control emanates from multiple, often overlapping and/or competing sources. This in turn leads to newer attempts to control. In this kind of space rule by chance - aleatory sovereignty - typifies power in a constantly shifting landscape.

As Lund has argued in his work on public authority in Africa, social life is 'constantly (re-)produced and sanctioned, not necessarily by one single body of "state", but by a variety of institutions which, in doing so, assume 
public authority and some character of the state' (2006: 688). Legitimacy is a crucial part of establishing authority, and what is regarded as legitimate varies within different spatial and social contexts. Further, legitimacy shifts over time and in relation to the actors themselves and issues on which legitimate authority is sought; it is established through conflict and negotiation (2006: 693). Lund goes on to argue that a key component of legitimising public authority is territorialisation through 'delimitation and assertion of control' over a geographic area (2006: 695). This is a key characteristic of the disturbed city, which is composed of multiple microsites of control and contention.

\section{Frontiers to Corridors}

The legacy of the disturbed city is lived through a contemporary moment of dual connectivity. On the one hand it is becoming better connected to Myanmar and onto Southeast Asia as part of the oft mentioned but rarely qualified 'Look East Policy' of the Indian Government (see Haokip, 2015). Imphal has become a staging post for all kinds of transnational ventures from highways to trade fairs to car rallies. No longer the end of the road, India's recalcitrant frontier plagued by rebellion and deprivation, Imphal is now very much on the road, metaphorically and materially speaking, linking South and Southeast Asia. Imphal is imagined as part of a zone of 'potential', where the irresistible force of India's rising power meets the seemingly unbound economic might of Southeast Asia and China - where anything and everything is produced and purchased. Better access to markets, somewhat mystically imagined, is equated to peace, opportunity, and development. Connectivity to the east has garnered a great deal of attention among journalists, scholars, politicians, and entrepreneurs in Delhi and in the borderland itself. It can be seen as a more natural fit; the Tibeto-Burman, Tai and Mon-Khmer inhabitants of the frontier becoming more formally linked with their co-ethnics across the international border (a problematic claim to be sure, but one made with startling regularity). Yet there has been significantly less attention given to the ways connectivity and the opening up of the frontier has necessitated greater connection between the borderland and the rest of India.

The flow of goods, people, and capital into Imphal does not just come from across the international border but from mainland India as well: outward connectivity to other parts of Asia and inward connectivity to the rest of India. The Indian state has increased its presence in the borderland 
for the last five decades through the military and paramilitary facilitated by categories like disturbed, by creating federal state units and attendant bureaucracies - made up of persons indigenous to the borderland and migrants from other parts of India, through party politics, and through objects that mark the landscape as Indian territory - statues of Gandhi, State Bank of India branches, Assam Oil and Bharat Petroleum fuel pumps, and distance markers from the Border Roads Association. In recent years new layers of 'India' have been added to the landscape of the borderland; though this is not the 'old' India of the military and the bureaucracy, but the 'new' India of the market. The arrival of new India is even more fascinating in Imphal where 'old' India never took hold and has been strongly resisted for decades.

Dual connectivity is transforming Northeast India in ways that resemble transformations taking place in borderlands across Asia, the transformation from frontiers to corridors. Transnational connectivity promises railways, highways, and visa-free regimes. It promises easier commerce to boost the economies of rural and provincial areas. These connections pass through borderlands. Not only do they connect borderlands and their residents across borders but also they connect them to heartlands within contemporary state boundaries. Better-quality infrastructure brings state authority right up the very edge of territories claimed. Yet it is not just the agencies of the state that gain access to the borderlands through greater connectivity. Borderlands become more attractive markets with more consumers and lower costs of transportation. Connectivity also reduces the costs of extraction from borderlands. Thus resources like coal, timber, animal and plant life are no longer as risky and expensive to extract - especially for state agencies and their private partners who can operate with the protection of the military. And it provides a faster, cheaper, and often safer route for borderland residents to migrate out of frontier to work in the heartlands. In the process of enabling flows of goods, capital, and people across borders transnational connectivity can bring borderlands more firmly into the national fold.

I am very wary of over-determining connectivity as a transformative factor in the economic, social, and political life of Imphal. Indeed not everything that happens in Imphal is a result of connectivity or a reaction to it. Rather, I view connectivity as characteristic of the present conjuncture; it captures the moment wherein borderlands are subject to particular experiments in state-making based on increasing accessibility for the private sector and increasing the capacity for cross-border movement - significant shifts from the security and state-led development approach that has characterised 
the decades since independence. Borderlands are fascinating vantage points from which to study national and transnational transformations. There has been a voluminous amount of literature analysing the impacts of neoliberalism (usually referred to as liberalisation in the Indian context) and globalisation in India, which will be discussed in chapter 5 . While this literature accounts for changes at the national and the subnational levels, there is limited investigation into the way these changes affect volatile territories at the very edge of the Indian state.

The borderland city is where these transformations are concentrated and contested, where the conjuncture is most intense. This makes Imphal such an appealing site. Connectivity has re-situated Imphal within India and as a conduit for flows beyond India. It is also where local territorial imaginations are enacted producing localised tensions and conflicts. In studying a city like Imphal there is an opportunity to conceptualise the borderland city as a particular urban environment, sensitive urban space if you will, and also capture the scholarly turn towards research on vernacular urbanism and small cities.

Bell and Jayne note that 'in developing countries two-thirds of urban residents live in places of less than 1 million people' (2009: 689). They argue that 'if the role and nature of small urbanity is to be more fully understood, a number of "imaginative leaps" must be taken by theorists currently hung up on the notion that globalisation of the city means globalisation of the metropolis' (2009: 690). Bunnell and Maringanti (2010) refer to this turn in scholarship as moving beyond 'Metrocentricity'. Moving beyond mega-cities also calls for more engaged ethnographic work, work that cannot be done from afar with secondary data (2010: 417). It is hard, slow work, but work that lends itself to ethnographic approaches and 'conceptual flexibility and a willingness to engage with plural traditions' (2010: 418).

This is a significant turn in Asia, especially South Asia, where small cities have received less attention from scholars, yet as Denis et al. (2012) demonstrate in the case of India, small, rapidly growing urban settlements are vital sites for understanding development and change. However, they remain almost completely obscured by the focus on mega-cities. In South Asia the small city is a hard sell. The mega-city dominates research in a number of disciplines, alongside work on the village or the rural region. Work on migration bridges the two, yet the small city remains marooned in between.

Imphal is also a borderland city shaped by its location on the periphery of the Indian state close to international borders. There is now a discernable 'next generation' of borderlands scholarship that is moving beyond 
advocating for the importance of borderlands towards locating borders within and outside contemporary nation-states and as part of globalised flows of people, goods and capital and innovative ways of reading these flows (Cons, 2016; Eilenberg, 2012; Harris, 2013; Reeves, 2014; Yeh, 2013). In this book I seek to place the borderland city at the centre of analysis rather than a component part of frontier polities, regions, or cross-border networks.

When it comes to research on Northeast India, cities rarely draw much attention despite the rapid growth in the urban population, discussed in chapter 2. Imphal is a surprisingly plural city. This may seem like a defining characteristic of any city, anywhere, yet in the Northeast cities are predominantly conceived as administrative headquarters for whichever ethnic group has been granted autonomy over the territory in question. Thus the state capital of neighbouring Mizoram, Aizawl, is assumed to be a city inhabited by Mizos, and the state capital of neighbouring Nagaland, Kohima, to be a city inhabited by Nagas. The Sixth Schedule protecting tribal lands and the creation of federal states in the borderland has institutionalised this demographic alignment, unlike across the border in Myanmar or in China where deliberate trans-migration policies have drastically altered the ethnic composition of cities like Lhasa or Myintkyina. In the Northeast ethnic plurality is rarely assumed despite the intersecting territories that shape the region's geography. The armed forces, bureaucracy, and the economy of counter-insurgency bring migrants to Imphal in large numbers. Manipur does not have any restrictions on migration from other parts of India, though communities in the hills fall under the Sixth Schedule, theoretically protecting their lands from other communities. Imphal is in the valley not the hills and as 'home' to the non-tribal Meitei population has no mechanism for restricting settlement. Decades of violence in the hill areas and the draw of economic and education opportunities in Imphal - whether or not these are realised - have brought internal migrants from the hill areas and other parts of the valley to the city. Connectivity has increased the flow of people into and from Imphal. Far from a Manipuri city in the Manipuri homeland - or even more specifically a Meitei city in the Meitei-inhabited valley, Imphal evokes Appadurai's concept of an 'ethnoscape', 'the landscape of persons who constitute the shifting world in which we live: tourists, immigrants, refugees, exiles, guest workers, and other moving groups and individuals' (1996: 33). Imphal is not a cosmopolitan wonderland like Qatar, Toronto or Singapore. Its plurality is relative, however, it is significant, given the fissures between Manipuris and outsiders and among the different ethnic groups indigenous to the state; fissures that play out in Imphal. 
In focusing on belonging and exclusion in Imphal I am interested in when ethnicity matters, for whom, and to what ends. Ethnicity in Manipur has been shaped by colonial anthropology, particularly the distinction between hill and valley communities aligned to tribal hill dwellers and non-tribal valley dwellers - a distinction widely critiqued but salient in contemporary politics (see Jilangamba, 2015). Thus while there is potential use in discussing these constructions - and many scholars of the region spend a great deal of time doing so - in postcolonial Manipur, these categories have been hardened through constitutional provisions aimed at uplifting the lot of tribal communities - primarily the Sixth Schedule - and by ethno-nationalist movements seeking ethnically exclusive homelands with various institutional structures based on these extant ethnic categories. Therefore while ethnic divisions in Manipur should not be taken as a given, the construction of ethnic difference along three main fissures is deeply embedded in the politics, society and economy of Manipur. Work that seeks to explore life on the ground must contend with the saliency of these categories rather than dismiss the often arbitrary and even absurd nature of their creation. All of these communities live in Imphal, and the pluralism of the city reveals the moments and sites where ethnic divisions break down and where they are hardened. As Brubaker (2006) argues in his study of everyday ethnicity in the town of Cluj in Romanian Transylvania, 'That ethnicity and nationhood are constructed is a commonplace; how they are constructed is seldom specified in detail' (2006: 7, emphasis in original). In Imphal spatial divisions between ethnic groups are present - divisions marked by ethnic symbols, places of worship, types of dwelling, graffiti, and the inhabitants themselves. At first glance these divisions are firm. Yet on closer inspection the firmness dissolves and can even disappear. In fact in some parts of the city firm divisions were never there in the first place. At other times ethnic boundaries harden leading to exclusion and violence. In these times belonging is realised on a smaller scale: the household, the neighbourhood, the laishang, church, or mosque.

\section{Approaching Imphal}

Research for this book took place from 2011 to 2014 over multiple visits to Imphal. In late 2010 I was conducting fieldwork with migrants from the Northeast living in Delhi, a study that itself built on a decade or so of work in the borderland (McDuie-Ra, 2012a). During my time living in a Northeast enclave in Delhi and visiting migrants working in malls, restaurants, hotels, 
and call centres it became clear that a large proportion of the young people leaving the borderland were leaving Manipur. This was especially true for migrants who arrived with few connections, resources, or plans - those at the bottom end of the migrant pool. They just needed to get out. Many wanted to stay out. They missed home, to be sure, but the prospects of having a future there was remote. The place was broken. These kinds of responses fit the image generated of Manipur and Imphal city in the national media: soldiers, shootings in the street, blockades of burning garbage.

Despite assumptions that Imphal is a Meitei city owing to its history as seat of the Meitei kings and its location in the valley, throughout my time in Delhi I continually met members of various tribal communities who called Imphal home. Some were born there, others moved there at a young age to follow their parents who went for work. Others went for their secondary schooling or on various scholarships. This raised questions that I couldn't let go: what was life like in the city for members of these different communities apparently locked in ferocious interethnic politics of exclusion? Did members of these communities get along? Does ethnicity even matter in Imphal? Moreover, what was everyday life like in a place so many were determined to leave?

In late 2010 there was a rumour going around among friends from Manipur living in Delhi; restrictions on foreign access to Imphal were to be lifted. I had been waiting for almost ten years for this news and it was hard to concentrate on the research I was doing in Delhi. Imphal was calling. However, the news was very hard to verify. Further, Manipur had just experienced a ninety-day blockade that had inflamed tensions between Meitei and Naga communities. It seemed unlikely that this would be the time to lift restrictions on foreign visitors. Friends from Manipur were also sceptical. Some thought it was a mistake. Some thought that if I set out for Imphal I would be turned back upon arrival. I went to Manipur Bhawan in Delhi, the state 'house', to ask if the rumours were true. The guards out the front were dubious that I had legitimate business inside but relented, perhaps for the novelty. Once inside no one was very sure who could answer my question. I was sent to various rooms in poorly lit maze of small rooms to meet baffled bureaucrats. Finally a beaming staff member located me with a photocopy of what looked like an official facsimile that stated that from January 1, 2011, restrictions on foreign entry would be lifted for a trial period. The staff member warned me that many of the officials in Manipur might not know there has been a change so I had better take a copy of the page with me. In February 2011 I arrived in Imphal for the first time and returned every few months through to the end of 2014. 
My approach to the research began with a more or less conventional ethnography based on engaging with people's daily lives: accompanying friends on their trips around the city on errands, to markets, festivals, weddings, to visit relatives, and having conversations at each turn. These friends would pass me onto other people they knew who had an interest in whatever I was pursuing whether illegal settlements, skateboarder hangouts, abandoned development projects, or new apartment blocks. Through this organic low key sampling I was able to learn more about a particular statue, neighbourhood, street, ritual, and narrow my focus to particular spaces and particular flows and explore these in more depth through targeted interviews with key informants along with continuing informal conversations with anyone willing.

I began field research with a very simple question: what has changed? This usually led people to discuss material changes: new houses, demolished shops, a new bridge, an abandoned school, more rubbish, or fewer trees. Respondents would then explain the causes of these changes and through these conversations I was able to gauge who was building big houses, who was settling in makeshift slums, where students from a particular neighbourhood were now going to school and what it cost and how parents managed to pay. I would be invited to follow people to see old rice mills, new malls, construction sites, weaving factories, and attend rallies. Asking about change also invited residents to talk about their fears, hopes, pride, and ways of making do.

Alongside gaining material from people I also gained material from reading the urban landscape - the material and symbolic dimensions of space and the dynamics that shape it. Lefebvre's (1991) dialectical approach to the production of space is a useful starting point. For Lefebvre, the urban is a level between everyday life and the existing order - and in the case of Imphal this order is shaped within and beyond the borderland, Lefebvre's 'near order' and 'far order' (Kipfer et al., 2013: 124). The urban is a space of 'encounter, assembly, simultaneity' (Lefebvre, 1979/2003: 118). It needs to be understood as a social force and the product of social forces produced through three connected dialectical processes (or 'moments'): spatial practice or perceived space, representations of space or conceived space, and spatial representations or lived space (Lefebvre, 1991: 33-42). The first process refers to material structures reflecting the spatial manifestations of social and political power, the second is the abstraction of this power as ideology, knowledge and language used for domination, the third is the space of everyday experience where material and abstract power are lived. These three moments are of equal value and enable analysis of the material 
and symbolic elements of space, how they are produced, challenged, and experienced. As he notes in the Production de L'space, 'In reality, social space "incorporates" social actions, the actions of subjects both individual and collective who are born and who die, who suffer and who act' (1991: 33). In Imphal this approach reveals the material, ideological, and lived experience of sovereign power produced by state, quasi-state and non-state actors and the ways this is marked on the landscape, on the built and natural environment.

To explore this - along with encounters with the people of Imphal - I paid particular attention to the landscape. I focused on: (i) billboards: which indicated what was being marketed and the symbols and images being used, (ii) posters: mostly glued onto walls and electricity poles announcing events from rock concerts to political meetings, (iii) public service announcements: including those from both state and non-state actors usually painted onto walls directly or printed on paper and displayed in shops and other businesses, (iv) graffiti: including political slogans, symbols and text marking underground territory, and street art, (v) memorials: including official statues of Indian figures and local nationalist heroes, war memorials, memorials to killed members of the armed forces, and killed members of underground groups, (vi) public buildings: from army headquarters to showcase public works, (vii) houses: new and old, big and small, traditional and contemporary dwellings, (viii) neighbourhoods: who lives in them, who patrols them, who marks them with their territorial claims, (ix) places of worship, (x) markets; mobile and permanent, illegal and legal, indoor and outdoor, and (xi) fields, forests, groves, ponds, and rivers in various states of ruin and rejuvenation. I took thousands of photographs of the landscape and shared these with friends and acquaintances who would interpret what they thought I had captured. Locals would also take photographs and share them with me, whether on their phones, by email, or from their own collections. Through this ongoing exchange (which continues through the writing of this book) I was able to build additional narratives of the city; an additional script to the things I witnessed in person. This combined with interviews and conversations forms the ethnographic material used in the book. Unlike my previous research where I depended on meeting people, I often spent long periods in Imphal alone with the urban landscape, or with one or two companions scaling a fence to look into an abandoned lot, searching for a rumoured memorial, or hanging out in a hospital cafeteria.

The visual landscape of Imphal is challenging. It can appear chaotic and illegible. Imphal has patches that are planned and orderly, and indeed a drive to create order is an important part of the city's development plan 
(Imphal Municipal Council, 2007). However, most of the material space appears haphazard. It is particularly challenging to read the appearance of chaos without reproducing its inferences. Here King's approach to reading urban space is useful in finding ways to dissect what appears impenetrable. King focuses on juxtapositions - namely attention to the positioning 'of the dissimilar and even the incompatible', superimpositions - what he calls 'activities piled on activities, screens on screens', and chaos itself which 'needs to be seen as a medium for resilience and survival, more rarely also for resistance' (2011: 12). These three concepts draw attention to the ways space is appropriated, officially and unofficially, temporarily and more permanently, all of which drive change in Imphal reflecting past and present configurations of power and their accompanying imaginations.

Sense also plays an important role in the articulation and demarcation of space in Imphal (see Low, 2013). In Imphal attempts to articulate and enforce acceptable sensory behaviour characterise relationships between:(i) tribals and non-tribals based on the food different communities cook and eat, the smell of illegal distilleries, the noise from religious worship and festivals, (ii) between different class groups, for example poorer areas are perceived as smelly by some urban residents because of the rubbish, the industry (metal works, incineration, animal slaughter), and noise owing to overcrowded dwellings and raucous behaviour often linked to rural sensibilities and alcohol consumption, while wealthier areas are imagined as quiet, odour free, and clean, (iii) between residents and the authorities, for instance, sensory disturbances are taken as indicators of ineffective urban governance and thus the smell of burning garbage and polluted watercourses, the noise and pollution of heavy vehicle traffic, and the aesthetic breaches of the built environment contribute to the perceptions of civilian authorities as corrupt, inept, or incapable.

\section{Structure of the Book}

The book is divided into two parts. Part one, Disturbed City, Sensitive Space explores the microsites of control and contention in Imphal through three chapters. Chapter 2, Belonging focuses on plurality, polarity, and neighbourhoods to sketch the different ways residents of Imphal maintain a sense of place in the disturbed city. I consider the more obvious ways of belonging, such as ethnicity, and alternatives, from sports to illicit eating and drinking. Chapter 3, Control is concerned with the control of urban space in Imphal and the ways this is contested. The first part of this chapter examines the 
armed forces, who control parts of the city by enacting security, and the civilian government, who control parts of the city through development projects and attempts to order urban chaos. The relationship between the armed forces and the civilian government is rarely seamless making it difficult to locate a singular hegemonic force in control of space in the city. The second part uses the example of memorials around the city to demonstrate the ways in which spatial control is contested by residents; a challenging task in the disturbed city. This tentative counter-hegemony reveals the small acts residents take to mark the landscape with memories of violence, loss, and defiance. Chapter 4, Exclusion shifts emphasis to the interethnic politics that play out in the city. Imphal is cast as an arena within which the territorial politics of hill and valley/tribal and non-tribal play out. Any notion of unified counter-hegemony is fragmented during periods of intense interethnic tensions, as during the blockades of the city in 2010 and 2011, when exclusion and belonging are negotiated through struggles among the population with the armed forces and civilian government as bystanders and occasional interveners. A much larger movement to exclude non-Manipuris from the city, and the state, in 2012-14 subsumed interethnic tensions and cast all Manipuris as indigenous peoples united in their precarious geographic and demographic circumstances at the edge of the Indian state. The movement seeks the implementation of the Inner-Line Permit system or ILP, a mechanism for restricting entry and monitoring the presence of non-Manipuris in the state. Once again Imphal is the arena where this plays out.

Part two, Liberalising the Frontier considers the ways in which inward and outward connectivity to India and to Southeast Asia shape parts of the disturbed city and vice versa. Chapter 5, Gateway City analyses the recalibration of Imphal as a gateway to Southeast Asia. Imphal is subject to vigorous bureaucratic imaginings as the gateway to a zone of potential where cross-border flows of goods and people will produce economic opportunities and diplomatic gestures with neighbouring countries will legitimise the borderland as part of India. This chapter discusses the campaign for Meitei Mayek script on all visible signage, the clothing trade, and the ASEAN car rally to demonstrate the unexpected opportunities and controversies of connectivity. Chapter 6, Health City uses the name given to celebrate the concentration of high-quality private health facilities in the city and investigates how world-class health facilities can exist in such a tumultuous polity. The poor conditions of the public hospitals as well as demand from patients across the border in Myanmar and other parts of the borderland have led to a thriving private hospital system driven by health 
entrepreneurs - mostly return migrants or defectors from the public system. This has produced alternative ways of enabling movement mobility across the border for patients that bypass Indian authorities. The boom in private healthcare has also transformed the landscape on the northern edge of the city and created new battles over land between settlers who moved into the peri-urban fringe in the 1990s escaping conflict and a new class of medical and other professionals seeking land and entrepreneurs seeking to build new facilities. Chapter 7, Education City analyses the private education boom taking place in the city fuelled by demand from parents and their children to gain qualifications to travel west for further education or work in other parts of India, a renewed possibility in light of better connectivity. The boom is also fuelled by the utter dysfunction of the public school system. New schools are extending the boundaries of the city in the southwest and diminishing the size of smallholder farmland on the peri-urban fringe. The cost of private schooling also affects the landscape as families in the hills sell land and timber to send their children to the education city. This is a kind of accidental liberalisation, which, as with the health sector, was born out of necessity, has become the norm and attests to the uniqueness of liberalisation in the disturbed city.

\section{Terminology and Place Names}

In this book I use official names for landmarks, wards and neighbourhoods in the city. Some parts of the city have alternative names, but these are only noted if they add something to the material being discussed. Only main roads have names, and where it is relevant I have used these names. Neighbourhood streets and laneways rarely have names. Where possible I use English language terms to describe various spaces, objects, and types of terrain - the exceptions are terms with no clear English language equivalent and in these cases I use the local term and have done my best to explain the term at first usage and have provided a glossary.

I use the term 'tribal' to refer to communities that fall under the Sixth Schedule of the Indian Constitution, which applies to 33 groups in Manipur. The term is Imperial, denotes backwardness, and is selectively applied (Barbora, 2008; De, 2014; Jilangamba, 2015; Karlsson, 2001, 2003; Xaxa, 1999). However, it is used by communities subject to the term, by the Indian Government and Manipur Government to govern these groups, and is a major determinant of rights claims for these communities. The term 'tribal' can create confusion given its use to identify tribal communities from central 
India, referred to in Hindi as adivasis. Adivasis are not related to Northeast tribals ethnically nor have they had a great deal of historical contact, and adivasis fall under a different constitutional provision (the Fifth Schedule). The term 'tribal' or adivasi is often considered pejorative when referring to these communities, denoting a position outside the caste system and the bounds of civility, whereas in the Northeast the term is internalised and a source of pride, akin to being identified as indigenous and being able to make claims on the state for reservations in education and employment, protection of ancestral lands, and recognition of traditional authority (see Van Schendel, 2011).

Tensions between tribals and the Manipur Government, which is perceived to represent the interests of the Meitei majority, are a crucial element of contemporary politics. Despite these tensions the category tribal is rarely questioned. In fact, there are members of the non-tribal Meitei community seeking inclusion in the Sixth Schedule as tribes, in part as a response to the supposedly unfair advantages to which tribal communities are entitled. They have an active organisation, the Scheduled Tribes Demand Committee of Manipur Valley, which even met with former Prime Minister Manmohan Singh in 2012. The Committee claims that extending the Sixth Schedule to Meiteis will better integrate the hill and valley communities of Manipur, that Meiteis still maintain animist traditions despite mass conversion to Hinduism (this is not an outrageous claim given the extent of revivalism of the pre-Hindu Sanamahi religion), and that tribal and non-tribal communities share racial lineage as Tibeto-Burman peoples. Yet as Piang argues (2014), the irony of the claim for Scheduled Tribe status is that it comes mostly from the upper-caste Meiteis, the $d w i j a$, or twice born, who have historically exercised a high level of prejudice towards tribal communities. Piang adds, 'after more than 65 years of independence, the forward classes of society are demanding the status of "backward classes"'. What is interesting about the claim is that it reflects the view that tribals have too many advantages from affirmative action policies and that in the contemporary era they are no longer disadvantaged vis-à-vis the non-tribal population; a view regularly voiced by Meiteis in Imphal during fieldwork. Yet tribals will counter with the opposite view, that they experience disadvantage when compared to the more populous Meitei who hold the majority of seats in the assembly, the majority of high-level government posts, and control a larger share of the economy. The important point here is that the tribal status is desired not shunned and thus I will use it in a similar way throughout the book. 
The two main tribal groups are the Naga and Kuki. These are not perfect amalgams and many smaller tribal communities resist incorporation into these larger groups. This means that sizeable communities like Hmar, Paite, and Vaiphei that do not always willingly yield to inclusion in the amalgamated categories are mostly invisible. However, for the sake of clarity I will use these umbrella terms in this book except where it is necessary to identify a more specific community.

I will use the term Meitei to refer to members of the Meitei ethnic group. I don't wish to suggest the Meitei population is homogenous, nor do I wish to suggest that the Naga or Kuki communities are either, and intra-ethnic distinctions will become clear during the course of the book. At various points I will use the term Manipuri to refer to all of the 'indigenous' peoples of the state; namely Nagas, Kuki, all other tribal communities, and Meiteis as well as the Pangal community of Meitei Muslims. Manipuri is a tricky term because it is often used to refer to the Meitei ethnic group only. In this book I will be using it to discuss politics of migration and the distinction made between Manipuri and non-Manipuri people. Indigenous is used in some of the campaigns against migration, and it usually includes Meitei, Naga, Kuki, and other tribal communities and thus I will use it from time to time when discussing this campaign, especially in chapter 4 .

Finding a term for the non-Manipuri population is a little more difficult. There are many people in Manipur, and Imphal especially, who have migrated from outside the state. Significant numbers have fled conflicts in neighbouring parts of the borderland and settled in Imphal, including from Mizoram, Nagaland, and Myanmar. These latter communities blend into the tribal population and are tolerated, more or less. Those who have migrated from other parts of India, Nepal, and Bangladesh are much more visible as outsiders, even those born in Manipur, and the term non-Manipuri is usually used to refer to these communities. The word mayang in Meiteilon (the Meitei language) is commonly used to refer to non-Manipuris in Imphal, though there are different words in tribal languages. Given this divergence I will use the term non-Manipuri in this book for the most part. I also prefer to use non-Manipuri as its use has forced consideration of the boundaries of being a Manipuri; an important component of the dynamics of belonging and exclusion that plays out in the city. In sum, I recognise the limits of all these terms, however, the terms have currency on the ground, in institutions, and in the public sphere. Given the contentious nature of most things in Imphal I have used pseudonyms for all of the people quoted or referred to in the text. The only exceptions are in quoting politicians or other public figures from statements they have made in the press or on the public record. 



\section{Part 1}

Disturbed City, Sensitive Space 



\section{$2 \quad$ Belonging}

In June 2013 I was searching the laneways of Yaiskul Hiruhanba Leikai, an established Meitei neighbourhood inhabited by descendants of the royal family and the Meitei aristocracy located just south of the central area around Kangla Fort, for 'the house with a big mandop'. It was more difficult than I expected. The houses in the neighbourhood were either behind outer cement walls or on the other side of pukhris, household or community ponds. Yaiskul is pleasant to walk around. There are few cars, there is little rubbish on the ground, kids are running around in the laneways playing ball games and firing slingshots into trees, and it's green. Screens of tall bamboo line the edge of family compounds adjoining cement walls, and fruit trees dangle from household compounds into the narrow dirt laneways, some with a phanek, the Meitei sarong, tied around the trunk to promote fertility. Beneath one bamboo grove there were a cluster of bicycles, the standard Hero model in various stages of rust, and a few white cars parked across the width oflaneway. A path led down to the mandop, a pavilion with open walls on three sides (sometimes four) and a ceiling used for rituals, theatre, music recitals, playing sports like kang, and for feeding guests during festivals and family and clan events. Mandop are found in the compounds of Brahmin families in Manipur, and remain one of the most telling visual clues as to the caste and faith of a family, and the ethnic composition of a neighbourhood (Singh, 1963). Mandops are reminders of the conversion of the Meitei population, at least part of it, to Vaishnavite Hinduism in the $18^{\text {th }}$ century, during which certain communities, such as the Chapka and Loi were considered outcaste, the majority of the population were considered Kshatriya, and Brahmin priests were imported from Bengal and eventually integrated into the Meitei ethnic milieu (Singh, 2001). The indigenous Sanamahi faith never really disappeared (Parratt, 1980), and indeed since the 1990s has undergone a major revival. In the face of the Sanamahi revival, in the aftermath of communist insurgencies in the 1980 os and 1990s, the continued influence of ethno-nationalist movements that reject imported faith from India, and with increased Christian conversion and settlement of Christians from the hill areas in Imphal, the social significance of Brahmins in on the wane (Parratt and Parratt, 1997: xiii). However, on this afternoon one would not known it.

In the mandop a crowd sat cross-legged in rows in front of a female performer who played a pung, a Manipuri drum, and sang a ballad about the struggle against the British. Adjacent to the performer was a scholar 
of Meitei arts who asked the performer questions during intervals in the ballad about her technique, how she learned her craft, and the lineage of the particular ballad. Two camera operators with heavy-duty equipment recorded the performance and the mandop was wired with a microphone and a small technical team sat behind an audio mixing board in the rear. A local performing arts institute, Laihui, as part of an initiative to revive classical Meitei artistry, sponsored the event. Unlike the performances in the halls of the various performing arts academies and state-sponsored cultural venues, the afternoon in Yaiskul was about bringing the performance to the public, to the neighbourhood. Such public performances can be risky in the disturbed city. Though the will to revive the artistic life of the city is strong, and at times this will outweighs the risks.

The late afternoon sun made long shadows on the pounded earth floor as the performance ended. The performance had been intoxicating and the crowd shared a sense of significance. I waited around talking to some of the people I knew in the crowd: a few musicians, scholars of the arts, journalists sent to cover the performance. I met one of the organisers. He was overjoyed. People came. It was a good sign. Life, at least here in Yaiskul, was free of the usual insecurities of the disturbed city - perhaps just for today, perhaps for much longer.

A small group of us continued talking in the laneway outside recalling when we had last seen each other, in one case it was in Munirka, a neighbourhood in Delhi where many young Manipuris stay during their time in the city, in another case it was in Imphal on my previous visit. There was still an hour or two of daylight left, enough time to sit down and catch-up. In Imphal this is a problem, especially after dark. A member of our group, Ning, suggested visiting a nearby neighbourhood where we could have an alcoholic drink. Alcohol is officially banned in Imphal. It is still available: smuggled from across the border, bought from the armed forces, or carried in luggage of migrants returning from other parts of India. Locally made 'traditional' alcohol occupies a more ambiguous position. Not technically covered by the ban on alcohol, it still has a social stigma attached and is often policed as if banned by both the authorities and social associations. A few members of our group made polite excuses and took their leave. Another said he would meet us there after taking a circuitous route to avoid a relative's house.

I climbed behind Ning on the back of his motorcycle and we followed Yaima and Sonia riding on another. We drove for just a few minutes over the Nambul River to Keishamthong Kabui Khul, a Kabui tribal neighbourhood. Compared to Yaiskul the houses were lower, most just a single storey with 
more timber and thatch and less cement. There were few large outer walls and most houses fronted the street rather than other dwellings in the one compound. Close to where we stopped was a line of small shops operating out the front of houses selling tobacco, snack foods, and newspapers. Unlike in Yaiskul where residents had spaces in their compounds to sit in the afternoon heat, here residents sat along the side of the road in plastic chairs talking. Most of Imphal's illicit drinking dens are in tribal neighbourhoods. Tribals have a reputation as excellent brewers of alcohol, a reputation often used against them in the form of stereotypes of drunkenness and immorality, and are less bound by the seemingly more rigid social norms and public morality of Meitei society.

We entered a nondescript house with a mix of blue cement and bamboo thatch walls. On the inside the walls were plastered with calendars, posters of snow-capped mountains, sports cars, and a European baby. We sat on low wooden stools around a very low table. The only light came from the street outside through the open doorway. There were a few other occupied tables and everyone, including the boss and the teenager serving customers, stopped to stare at us while we sat. I assumed this was because of me, a very foreign-looking foreigner, and this was part of it, but we also had a woman in our group, Sonia- a Meitei woman, and this was an uncommon sight in a drinking den.

We ordered Sekmai, a rice whiskey named after the village where the best stuff is made. We ordered meat too, as drinking dens offer a place to ignore food taboos that are an integral part of Meitei life but are not common among tribals who have the reputation for excessive meat eating and no qualms when it comes to eating a wide range of animals. Like alcohol consumption this is used against tribals to suggest simplicity and savagery (see Kikon, 2015). The clear Sekmai arrived in a re-used Indian whiskey bottle with a plastic jug of water on the side. We ate pork and beef and my companions swapped stories about social life, or the lack of it, in Imphal.

After an hour a white Maruti Suzuki with a mounted gun on the roof pulled up outside in full view through the door of the drinking den. Four members of the Manipur Commandoes alighted from the vehicle with automatic rifles slung over their shoulders. Customers took action quickly, handing bottles of Sekmai to the teenager who hurried out the back of the house with them. Drinkers either swallowed what was in the glass or poured it into the water jug. I had heard so many stories about police and soldiers entering drinking dens and taking money from the owners for selling alcohol and the customers for drinking it. I had heard a few where customers were taken away in vehicles until they could muster enough 
money for their release. Being picked up in a drinking den could be a prelude for all kinds of harassment, detention, and worse.

I was expecting the soldiers to enter at any time, it seemed everyone was. But they didn't. Their vehicle was still outside. After a while, and after consuming enough raw onion to temper the smell of alcohol, we all got up from our table and went outside to have a look. The vehicle was still there but the street was empty. There was no sign of the soldiers. The plastic chairs lining the street lay empty. The small shops had all closed. The boss ushered the other customers out of the drinking den and he closed the door. As we were getting set to leave two of the soldiers emerged from a laneway a little further down the street. They approached and asked the small group of recently evicted drinkers a few questions. They were looking for someone and wanted to know if he had been seen. The other two soldiers came from the other direction and they conferred with one another outside the vehicle and left. I was expecting the street to magically spring back to life. It didn't. A man came outside to collect some of the plastic chairs from in front of his house. Everyone else had dispersed. We did the same. When we were stopped in traffic back on the main road Ning admitted he was very worried because he is not from that area. If anything happened his family might not ever know.

The afternoon was a telling illustration of belonging in the disturbed city. The two neighbourhoods are only 700 metres apart but look, feel, smell, and sound different. The inhabitants of the respective neighbourhoods are drawn from a particular ethnic group, and within that ethnic group a particular subset based on class (and caste in the case of Yaiskul). The different neighbourhoods have different built environments, different landscapes based on the preferences of their inhabitants, their resources, and their history. In one you can witness a public performance of high culture, a classical Meitei ballad. In the other it is acceptable to drink alcohol and eat meat - though for some residents, anonymity is a necessary requirement for such enjoyment. This could perhaps be the case in any diverse, plural city. Until the Manipur Commandoes show up and the neighbourhood shuts down. Safety can turn to insecurity very quickly. And the need to belong, to be known and seen by others in moments of insecurity, is vital.

This chapter focuses on plurality, polarity, and neighbourhoods to explore the different ways residents of Imphal maintain a sense of place in the disturbed city; in the sensitive space to draw on the concepts set out in chapter 1. The first section presents demographic information about Imphal to show that, despite being a small city, it is growing rapidly and its density keeps residents at close proximity to one another. The second section discusses ethnic politics in Manipur and the ways these are reflected in 
the urban landscape of Imphal. The third section profiles the ways ethnicity and belonging aligns with neighbourhood boundaries. The final section discusses the alternative spaces of belonging, and their limitations, through which some residents transcend the exclusive politics of belonging that characterise everyday life in the disturbed city.

\section{Small City, Growing City}

The population total of Imphal municipality is 414, 288 (Census of India, 2013), though this figure is based on dated city boundaries that have long since been surpassed by new settlements. It is very unlikely that the migrant population from outside the state is fully captured in this figure. Furthermore migrants from hill areas and other districts are usually counted in their home district for the census, especially if that is where they own land. Imphal occupies a relatively small area, officially 34.48 square kilometres. It is administered as 27 wards, most of which are less than 1 square kilometre (Imphal Municipal Council, 2014). There are some exceptions; the rapidly expanding Uripok Yamben Leikai and Iroishemba wards on the northwestern fringe of the city together account for around $14 \mathrm{~km}$ sq., but overall Imphal is divided into small, densely populated administrative units.

The municipal population doubles when considering the populations of the two districts that dissect the city and spread out to the edges of the valley. Imphal East and Imphal West districts have a combined population of 975,00o people representing $38 \%$ of Manipur's 2.6 million people (Census of India, 2013). Across India urbanisation outside former municipal boundaries is responsible for almost a third of urban growth for the period 2001 to 2011 (Prahdan, 2012). In Imphal the agglomeration of built-up areas (the settlement agglomeration as opposed to the urban agglomeration) goes well beyond the municipal boundaries; as can be seen using satellite imagery and through a cursory glance at the names/classifications of areas outside Imphal's 27 wards such as 'ward of outgrowth' (e.g. Naorem Leikai), 'census town' (e.g. Naoriya Pakhanglakpa), and 'plan area' (e.g. Porompat Plan Area). As Denis et al. (2012) argue, there are incentives for maintaining a rural classification in India, including eligibility for certain forms of government assistance, and many densely populated 'built up' areas that adjoin cities continue to be classified as rural areas. City-level governance is also weak in India when compared to state and district level. This is further complicated in the borderland by overlapping layers of authority - including traditional decision making bodies - over territory now part of growing cities. There is 
little incentive to expand the reach municipal authority to all areas within the settlement agglomeration given it has limited power and resources. There are powerful interests that benefit from ambiguity over boundaries, especially in the south and southwest of the city where farmland is being rapidly converted into schools and hostels, discussed at length in chapter 7 . Though rather than any deliberate strategy it is more likely that administrative categories are just slow to catch up with the rate of urban growth in Imphal given the general dysfunction of civilian governance.

Official figures for population density are calculated on district population figures: Imphal East has 643 persons per square kilometre and Imphal West has 998 persons per square kilometre (Census of India, 2013). As these also include peri-urban and rural areas it is likely that parts of the city have a much higher density and areas away from the city have much lower density. For perspective, the average density in Manipur is 115 persons per square kilometre, and thus population density of the valley is much higher than the hills. Decadal population growth in Imphal East was recorded at $69 \%$ and Imphal West $15 \%$ for the period 2001-11. Even based on these limited figures it is clear that Imphal is a relatively small city of between half a million and a million people, is densely populated when compared to the rest of the state, and it is growing.

\section{Image 2.1 Central Imphal facing north}

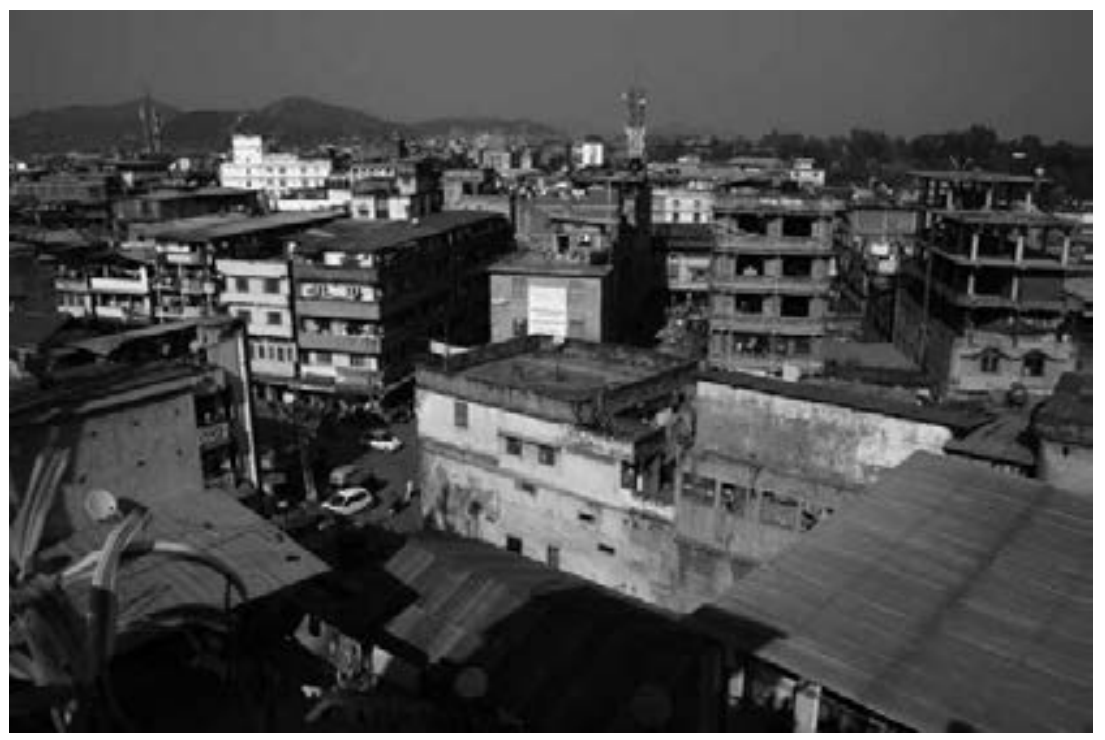


Imphal sits in a valley surrounded by the hills of the north-south Patkais running from the eastern end of the Himalayas to the meeting point of the Bay of Bengal and the Andaman Sea, forming a natural boundary between Myanmar to the east and Assam and Bengal to the west. The majority of the land in Manipur is hills. The valley, however, holds the majority of the population. This is part of Van Schendel's Zomia (2002), a zone of shared linguistic, cultural, and ecological traits but one that is 'relegated to the margins of ten valley-dominated states with which it has antagonistic relationships' (2002: 654). In The Art of Not Being Governed, Scott argues that as valley 'civilisations' spread through the expansion wet-rice cultivation and 'enclosed' non-state space, various peoples wishing to escape taxes, conscription, warfare, slavery, forced labour, and disease headed for the hills. These 'shatter zones' out of range of state authority were characterized by linguistic and cultural diversity and by relative geographic inaccessibility (2009: 24). Scott argues that the attributes labelled barbaric are not signs of pre-civilisational peoples but adaptations to life in shatter zones and the continuing imperative of hill peoples to evade assimilation and incorporation into the state. In the context of Manipur, Scott's argument has been embraced enthusiastically as it appears to narrate, and historicise, the apparent differences between hill and valley communities. Yengkhom Jilangamba is critical of both the hurried application of Scott's argument to Manipur - stemming from the ease of an 'already available template of the binary between the hill and the valley to which Scott's theory can be easily incorporated' (2015:10) - and the ways the seemingly 'natural' divide reproduces colonial systems of classification and domination. This politicisation of these categories will become apparent in later chapters of this book and is instrumental in understanding everyday life in contemporary Imphal.

Imphal is the built on the site of the former court of the Meitei Kingdom centred on the Kangla Fort, still the physical and spiritual heart of the valley polity. The Cheitharol Kumpapa, the court history of the Meitei Kingdom, dates the polity to 33AD. This date has been challenged by noted Manipuri historians such as Arambam Parratt (2005), Jilangamba (2010a) and Kabui (1991) who note inconsistencies in practices of recording time, the ambiguity of records before 1485 , and the use of astrological calculations to arrive at the date as important factors. Challenges to the 33AD foundation year are complicated further by colonial accounts in which the "onset" of Hinduism was considered as the historical marker' (Jilangamba, 2010a: 336).

These debates aside, the site where contemporary Imphal is now located has been settled for many centuries and the polity consolidated among particular Meitei clans, or yeks, marginalising others, and developing tribute 
relationships with communities in the hills and with other borderland polities including present day Assam, Bengal/Bangladesh, China (Yunnan) and Myanmar (Parratt, J., 2005). Imphal also spent periods under Burmese rule, which shaped identity, internal organisation of the polity, and created a diaspora of exiles still scattered through parts of the borderland (see Parratt, 1979/2012). The British took control of the valley in 1891 following the Anglo-Manipuri War and installed the 11-year-old Chura Chand as rajah (see Kabui, 1990a). The British period saw a major reorganisation of Imphal, and the construction of new markets, water supplies, and schools evicting communities living close to the centre of British administration around Kangla Fort. Highly significant in this period - particularly for events in contemporary Manipur - was the arrival of migrants from other parts of Empire to trade and serve in the occupying armed forces.

The British replaced the lallup system of unpaid (compulsory) labour by able-bodied men with the patta system of land title and taxation, effectively replacing in-kind tribute with monetary tribute (Parratt, J., 2005: 11-12). This changed the way space was claimed and controlled in Imphal. The extent of British involvement in the hill areas of what is now Manipur was debated between advocates of intervention and isolation, as elsewhere in the borderland (see Guha, 1999). The hills were also reorganised, though less intensively. The authorities in the valley appointed Meitei lambus, or officials, who became intermediaries between the valley authorities and the hill chiefs and headmen. The lambus implemented British policies such as the 'hut tax' and conscription into labour corps during the First World War (Parratt, J., 2005: 14). The hut tax imposed a tax on dwelling rather than land in order to gain revenue and extend colonial authority into the hill areas where communities had limited private property regimes. As Jilangamba argues, there were other incentives to impose the tax, and levying house-tax was deployed with the promise of guaranteeing protection to the villagers' extending colonial control - a tactic that was not always successful (2010a: 257). Deploying Meiteis as tax collectors altered the ways hill and valley communities related and equated the Meitei lambus with the punitive practices of the emerging sovereign.

In the 1930s Imphal was at the heart of uprisings against colonial rule and against the monarchy. At the forefront were women's organisations, Sanamahi revivalists, anti-feudalists, communists, Manipuri nationalists, and hill communities (Parratt and Parratt, 1995/2012; Bhadra, 1975; Longkumer, 2010; Singh, 2012). The Second World War brought violence, destruction, and demographic change to the city, but is also claimed to have 'forcibly dragged it into the modern era' (Parratt, J., 2005: 93). After 
a brief period of autonomy between the end of colonial rule in 1947 and the controversial Merger Agreement that bought Manipur into the Indian Union in 1949, Imphal was a district headquarters (till 1956), the capital of a union territory, and since 1972 the capital of the federal state of Manipur.

\section{Plurality and Polarity}

It is important to state at the outset that the following section is not an attempt to describe, explain, or deconstruct ethnic politics or ethnic categories in Manipur. This has been done with far more skill by other authors in recent years (Hanjabam, 2008; Haokip, 2013; Kipgen, 2013; Kom, 2011; Kshetrimayum, 2009; Parratt, J., 2005; Piang, 2014; Oinam, 2003; Phanjoubam, 2005; Shimray, 2001). The focus here is the city, its pluralism, and the ways different communities find ways of belonging in this landscape. The politics of exclusion, constitutive of the politics of belonging, are the focus of chapter 4. Imphal is a plural city. It is home to significant communities from all of Manipur's ethnic groups, migrants from neighbouring countries such as Bangladesh, Myanmar, and Nepal, and from other parts of India. Imphal's plurality does not produce immovable divisions between communities, but ethnicity is crucial to the ways urban space is inhabited, governed, and contested. Imphal is a patchwork city, masquerading as a relatively homogenous Manipuri city or Meitei city to outside observers and in the discourses of hill-valley politics. These patches are fundamental to belonging and exclusion.

Imphal's plurality is relative for its size, location, and geopolitical circumstances. A similar degree of diversity in an urban area, even a socalled 'small city' would be unsurprising in many other parts of Asia and indeed in many of the multi-ethnic borderlands of the region. However, in the Northeast borderland it is significant because the reverse is more common, namely ethnic exclusivity - or at least the institutionalisation of such within federal state boundaries and the cities developed to administer them. There are two reasons for this. First, special constitutional provisions to protect property for Scheduled Tribes and restrictive immigration policies, most notably enforced through the ILP system has limited the number of migrants settling in cities in the borderland, though this is not so in Assam and Tripura where there are few restrictions, and to a lesser extent Shillong, the capital of Meghalaya which served as a capital for the whole region at one point and has colonial-era zoning that enables non-tribals to own land and business in the city centre. After the Merger with India, 
Indian citizens were no longer considered foreigners and faced no formal obstacles to settling in Manipur (UCM, 2005: 26). Imphal has not had a restricted entry policy for Indian nationals since $195^{\circ}$ and nor for Nepali migrants between $195^{\circ}$ and 1978 , though a restriction on other foreign visitors was in place until 2011.

Second, the mass reorganisation of the Northeast borderland (1963-87) in response to violent and non-violent movements for autonomy that produced the boundaries of contemporary federal states and autonomous districts was predicated, more or less, on political units that corresponded to particular ethnic or tribal groups and the creation and/or rapid development of urban centres to administer these units (Baruah, 2003). Thus cities in the borderland, especially in the hill states, correspond to the ethnically exclusive polity in which they are situated or were created. In other words, cities within territories won or granted by the Indian state in response to secessionist movements, have been inhabited primarily by the communities for whom the territorial arrangements were devised. Imphal never quite fit this mould given its longer history of urban settlement. When the state of Manipur was formed within India in 1972, Imphal was made capital of an ethnically diverse state, as opposed to an ethnically delimited one, and the city was not created anew but inherited centuries of interethnic mixing. However, the territorialisation of Manipur's ethnic politics in the last three and a half decades has expunged the diversity of the city's past; at least rhetorically (Jilangamba, 2015). As divisions between valley/hill and Meitei/tribal have hardened, Imphal is re-imagined as a valley city, with a valley population, governed by valley-favouring bureaucracy.

Official statistics do not draw out the city's plurality. With no adequate data on the urban or settlement agglomeration, in other words, no statistics that accurately depict the population of the city it is very difficult to determine the ethnic demographics of the city. The percentage of Scheduled Tribes (Naga, Kuki and the various other groups classified under the Sixth Schedule) in Manipur is 39\% (Census of India, 2013). Individuals and families from the hill areas of Manipur reside in Imphal, often without owning property (and hence their relative invisibility in demographic indicators) for short periods, several years, and entire lifetimes. Some arrive as internally displaced persons, some as temporary or seasonal migrants seeking work in the city when the harvest season is over in the hills, some to attend school, to work, to take up government jobs and training, and prior to or after migration father afield - using Imphal as a hub for entry and exit. Most of these migrants still maintain a presence back in their ancestral village, whether through fields, property, relatives, or registration to vote. 
In fact it is very important given the highly contentious nature of territorial politics in Manipur that various ethnic and tribal communities can demonstrate their strength in numbers and contiguous habitation over tracts of land. In short there are few incentives to transfer all aspects of one's life to Imphal if moving there from the hills. For migrants from outside Manipur, non-Manipuris or mayangs to return to terms discussed in chapter 1 , there are major incentives to be completely invisible, with the exception of well-established business families and employees of the central government and armed forces. As will be discussed in chapter 5 , during activism over migration, volunteers identify and evict migrants from outside Manipur door-to-door in certain areas of Imphal.

Despite the association of Imphal with the Meitei community, migrants from the hill areas within Manipur and other parts of the borderland have established neighbourhoods, peri-urban villages, and clusters of dwellings throughout the city. There are many drivers of migration from the hills to Imphal; refuge from armed conflict whether with the armed forces or between ethnic groups - particularly the Naga-Kuki clashes of the 199os - which has brought whole families and even whole villages to settle in Imphal, migration for education, migration to join branches of underground groups operating in the city, migration for work in the city including everything from government jobs with housing to working in hotels, markets, and brothels. Some of this migration is permanent, some is temporary, and some people from the hills have houses in Imphal and in their ancestral villages and towns. When interethnic politics experience flashpoints, such as during blockades, some members of hill communities leave the city until things calm down, especially if there are counter-protests in Imphal targeting a particular organisation and the ethnic group/s that it claims to represent. Thus it is common for families who can afford it to hold onto land in the hill areas in case they have to return there for a period of time or permanently. Though there are also tracts of land on the outskirts of the city being purchased by hill communities for the same purpose - a place to resettle if conditions in the city deteriorate for their community - the one I visited was on the road between Imphal and Ukhrul.

Meiteis from outside Imphal have also moved to the city for similar reasons of education, livelihood, and to get away from conflict. Return migrants who have been living and working elsewhere often settle in the city when they come back to Manipur rather than in their ancestral villages or in regional towns. With so many migrants from Imphal outside Manipur, especially young men and women in their 20 s, there is an emerging labour vacuum in certain sectors of the economy (see McDuie-Ra, 2013). The 
absence of young women from extended families means that more domestic helpers are required, and usually come from outside the city. And of course, migrants from neighbouring countries and other parts of India come to the city to start businesses, find work - often from other migrants, serve in the armed forces, take central government postings, work in NGOs and development organisations, and as sojourners, opportunists, and hustlers.

The civilian government is often seen as representing the interests of the more numerous Meitei: especially among non-Meitei inhabitants of the city who argue that the authorities pursue an ethno-nationalist platform in everything from the provision of services to the allocation of trading licences to the motifs in public architecture. However, it is also common to hear inhabitants from all communities charge that the civilian government is dysfunctional, corrupt, and predatory in ways that affect everyone aside from elites and their well-connected associates.

\section{Neighbourhoods}

Where demographics fail to capture Imphal's plurality, the visual landscape is a compelling illustration. Neighbourhoods are perhaps the most telling features of the landscape that reveal plurality and the 'tight spaces' (Bollens, 2012: 13) shared by different communities. As the state and the armed forces provide little of the social fabric necessary for everyday life, neighbourhoods are where people come together and 'the daily rituals of life are performed'; integral practices for belonging and the creation and maintenance of place (Friedmann, 2007: 272). Appadurai posits that 'neighbourhoods are inherently what they are because they are opposed to something else and derive from other, already produced neighbourhoods' (1996: 183). In Imphal, belonging in a particular locality involves recognising the difference between that particular locality, other localities, and the city more broadly. This difference is predominately articulated in ethnic terms though within ethnic groups there are differences based on wealth, occupation (especially between those living in government quarters and the rest), between new arrivals and long-term occupants, and between titled settlements and informal settlements.

I spent the majority of my fieldwork walking around Imphal neighbourhoods, visiting residents, sharing meals, attending rituals and religious services, watching sports (and participating on occasion) and sitting on rooftops, on the roadside, and in illicit drinking and eating dens. Some neighbourhoods are inhabited by one ethnic group, such as distinctly Meitei 
neighbourhoods like Bamon Leikai or distinctly Naga neighbourhoods such as Nagaram. Within an ethnic group there are neighbourhoods that house long-time residents in one part of the city, such as Haokip Veng - a Kuki neighbourhood close to the old palace, and areas that house more recent migrants such as in Iroishemba on the city's northwestern fringe. Other neighbourhoods are ethnically mixed. Of particular note is the concentration of non-Manipuris in the commercial areas of Paona Bazaar and parts of Thangal Bazaar including those who have been in the city for generations and recent arrivals. During agitations against non-Manipuris these areas become flashpoints of violence as will be seen below.

The diversity of these neighbourhoods makes them very difficult to characterise. Cues can be taken from the visual landscape; including both what can be found in a neighbourhood and what is absent. Distinctly Meitei neighbourhoods are characterised by multiple dwellings for different branches of the same patri-local family in one compound, the remnants of traditional Meitei architecture - the yumjao - often in the oldest dwellings in a family compound, the centrality of a pukhri - though many are filled with cement to provide more room for dwellings, cremation grounds - often a raised cement platform close to a watercourse, and laishang - shrines for worship of Meitei deities that are found in households, family compounds or clusters of houses, and in neighbourhoods. There is also graffiti in support of Meitei underground groups in some neighbourhoods, though this is less common as the armed forces have gained control over more of the city in recent years. Pangal neighbourhoods like Hatta over the Imphal River from the Kangla Fort feature mosques, cemeteries, halal butchers, and small offices for Hajj committees and social associations.

Tribals have clearly demarcated neighbourhoods throughout the city. Many of these are relatively new neighbourhoods built in the 1990s when tribals moved from the hills in large numbers fleeing internecine violence to areas like New Checkon and Langol. These resemble the 'arrival city'; a term used by Saunders (2010) to describe a transitional space between village and the city and through which linkages between rural and urban lives are maintained. There are also sites on the outskirts of the city or in pockets that have not been developed during urban expansion given their proximity to armed forces headquarters or hillocks where tribal neighbourhoods resemble villages with a cluster of low houses around a common patch of land and trees (as behind the Assam Rifles HQ at Chingmeirong), and in some locations, livestock. Tribal neighbourhoods usually feature churches ranging in size from grand cement and stained glass buildings able to house hundreds of worshippers to small house-churches. And in the 
urban peripheries churches can be incomplete, just a frame of a building, a crucifix, and a name - part of a tactic of claiming land and preventing the government from evicting the community emerging in that location (see chapter 6). Tribal neighbourhoods usually don't have pukhris, cremation grounds, or laishang, just as Meitei neighbourhoods don't have churches or mosques.

Established tribal neighbourhoods are also distinguished by gates at their entry and exit as would be found in villages in the hills. This can create some remarkable circumstances in demonstrating the ways space can be controlled 'from below'. For instance, in Majorkhul, a tribal neighbourhood now in the epicentre of the very busy Thangal Bazaar, the community closed the neighbourhood gates during one of my visits to observe the funeral of a community leader. The streets of the neighbourhood were converted into a community space under a white marquee. The gates remained closed for several days. Detours were set up in the narrow streets and lanes of the bazaar. The police were even deployed to direct traffic around the neighbourhood. Though a relatively minor disturbance, there was no attempt by the authorities to intervene. This example shows the ways in which communities can exercise a modicum spatial control over 'their' territory from time to time. Of course, gates are not an impediment to the armed forces.

However, these characterisations only hold for neighbourhoods where there is a single or a dominant community. Other parts of the city are more internally plural; clusters of households from different ethnic groups, churches and laishang juxtaposed on opposite street corners, eating joints clandestinely serving beef and dog half a block from Hindu temples, graffiti from rival underground groups on opposite walls of a laneway. Government housing areas have uniform drab box-style dwellings but are usually very ethnically mixed.

Often plurality reflects economic imperatives and interethnic dependencies. An example is Ragailong, a Kabui Naga neighbourhood adjacent to the Khuman Lampak Sports Complex settled by tribals from neighbouring Tamenglong District prior to the 1949 merger. It presently has around 200 houses and can be easily covered on foot. The main street features a neat row of single-storey houses, some made from timber or thatch but most now made from cement, and large four- or five-storey cement houses at irregular intervals. For decades land was appointed at the behest of the headman, as it would be in a Kabui village in Tamenglong District. In the last ten years formal land title has been extended in the neighbourhood enabling Kabui residents to lease dwellings to non-Manipuri migrants, as 
well as a few families from the hill areas. Thus those with some capital have extended their houses upward by adding new floors, and in some cases added additional dwellings to their plots - especially those along the roadside to provide more space to lease for migrants to run small businesses.

One evening in December 2012 I was a guest of a small neighbourhood association with a broad social and cultural mission to educate the youth of the area on their heritage, language, and indigenous religion. In their office on the ground floor of a five-storey building on the main street running through Ragailong we talked about the history of the neighbourhood. After some time the headman of the village, Gangmei, joined us. He was fascinated that someone wanted to know about a small patch of land that was now effectively a suburb of inner-Imphal in close proximity to Kangla Fort and the main highways. He traced settlement to the British era when Kabui were brought to work in a nearby cantonment, now occupied by the Assam Rifles just outside the neighbourhood gate. He believes Burmese vacated the area, but he wasn't sure. He talked about his childhood, especially visiting the palace. Dusk came. Teenagers from nearby came to listen. Gangmei pointed to them and said they don't know anything about their past or their traditional religion. We talked about what had changed.

For Gangmei this neighbourhood was different to many others in present day Imphal because people did not have walls around their houses or fences. They came out onto the street in the evenings and they weren't scared. Though he admitted that there were bombings around the area sometimes as they were close to the Assam Rifles, and after a bombing the paramilitary would do combing operations through the neighbourhood. But he was right. The neighbourhood had a very different feel to many of the others in the city. The road was wide and had little traffic. It became a playground in the evening. The houses were built further back from the road giving more shared space in front of the houses where families were sitting, children were playing, and youths kicked footballs in the fading light. At one end of the neighbourhood a group of non-Manipuri tenants, all men, sat in a circle chatting. Others joined as they entered the neighbourhood after their day at work; a few of them held harnesses used on construction sites and in the market to carry heavy loads. It appeared that their place in the neighbourhood was well defined, spatially and socially.

A similar answer was common in other parts of the city when I asked about the extraordinarily large houses Gangmei answered: 'relatives of ministers or big-shots'. This explanation was common in other neighborhoods too, along with inferences about connections to the murky world of elites, the armed forces and underground groups, as well as money sent back by 
relatives working outside the state. The houses appear excessive; especially in contrast to smaller dwellings that surround them. Though in many cases there were several generations and branches of one family living in a five- or six-storey house. Many families had been building up rather than outward given the challenge of finding enough land on existing family or clan plots. In other cases spare floors are rented out to the stream of migrants entering the city looking for work or seeking refuge from insecure lives elsewhere.

The neighbourhood landscape of wildly varied dwellings reflects the dynamics of the disturbed city. As Herscher has written in the context of Kosovo, culture and violence is inscribed in architecture, its destruction and construction (2010:4). In other words violence is not only evident in what has been lost, broken, or bulldozed, but in what is built in its place. In a city characterised by fragmented sovereignty between state, non-state, and quasi-state actors where various actors take on state like quality and agency, the urban landscape reflects these shifting - and overlapping nodes of power. Corruption and illicit activity enrich a segment of the population, who plough their wealth almost exclusively into enormous houses and large cars. Dual connectivity is also useful for conceptualising the flows of resources into Imphal; from the west come the vast transfers of funds from the Indian Government as part of their twin development and counter-insurgency strategy along with remittances from Manipuris working outside the state, and from the east the wealth gained through smuggling, taxing, and trafficking of goods from across the border. The houses of those successful in these ways of making do stand out starkly in their respective neighbourhoods. The very processes of appropriation that enrich this class of urban resident ensure the gap between them and everyone else remains wide. Further appropriation, especially of public funds, means the services planned, or perhaps imagined, for the rest of the population are either absent, dysfunctional, or limited to those able to pay bribes or fees to access services, as with the provision of water throughout the city.

At various times during the year the municipal water supply experiences chronic shortages. The civilian authorities blame the rapid expansion of the city, often attributed to unchecked migration, and the growth of unplanned (mostly poor) settlements (Imphal Municipal Council, 2007). Some residents claim government workers sell off the water supply to private operators to manufacture scarcity and drive up prices, opening the door for illegal operators. There are other reasons too, the demise of household pukhris or ponds in the drive to build bigger houses, the demise of community pukhris in the corrupt planning process that erases public space to allow an illegal 
extension or new dwelling, and the pollution of common watercourses. The government price is fixed at a reasonable rate, but when it doesn't get delivered residents pay more for illegal supply. Illegal operators pump water from the Imphal River and other urban watercourses, often bleaching the water before selling it in neighbourhoods from trucks, portable tanks, and even cycle-operated carts. The pumping and reselling of water is easy to observe, especially in the dry season. One only need walk along the Imphal River or spend an afternoon in a neighbourhood that has not had reliable supply for a few days. Inevitably an illegal supplier will arrive, sometimes procured by a neighbourhood association or even underground groups. The persistence of the practice suggests complicity at some level of officialdom. Interestingly during the dry season, local politicians are said to arrive in neighbourhoods with government water tankers and distribute free water to residents, though I was never able to witness this. The point to note here is that regardless of how deep the complicity and corruption, there is both a general acceptance of this kind of corruption and the recognition that one needed to make do in other ways in order to be able to afford the basic public services that were otherwise denied by other people making do. Returning to the discussion of agency in chapter 1, if making do entails 'tactics for seizing opportunities and negotiating risk' (Pine, 2012:10) then in the disturbed city residents often justified their own tactics of appropriating money or resources or using connections as a way of overcoming the corrupt practices of others. As one respondent put it, they needed to ask for bribes in their own job to pay the bribes everyone else was asking for.

Diaspora housing, new houses or extensive additions to old ones show another way of making do for the less well connected, namely leaving Imphal to work outside the state and sending money back to family. The physical manifestation of migration in bigger, fancier, and more modern houses perpetuates the aspiration of migration for education and to earn remittances among the population, with further consequences for the ways urban space is used and controlled, as will be discussed in chapter 7 . Connectivity also has a part to play in the flow of construction materials into the city: cement, corrugated iron, and gyprock from India and other parts of the borderland, tinted glass, fancy tiles, linoleum flooring, and all manner of other construction materials from across the border, much of it produced in China. Other material is from within Manipur, timber, bamboo and clay, mostly from the hills, though timber from Myanmar also ends up in Imphal. Parts of this landscape evoke the 'wedding cake' architecture of Kabul as described by Feenstra that reflects a sudden influx of money, returnee migrants, 'copy-paste architecture' styled on 
Image 2.2 Multi-storey houses alongside partially completed houses, Uripok Khumanthem Leikai

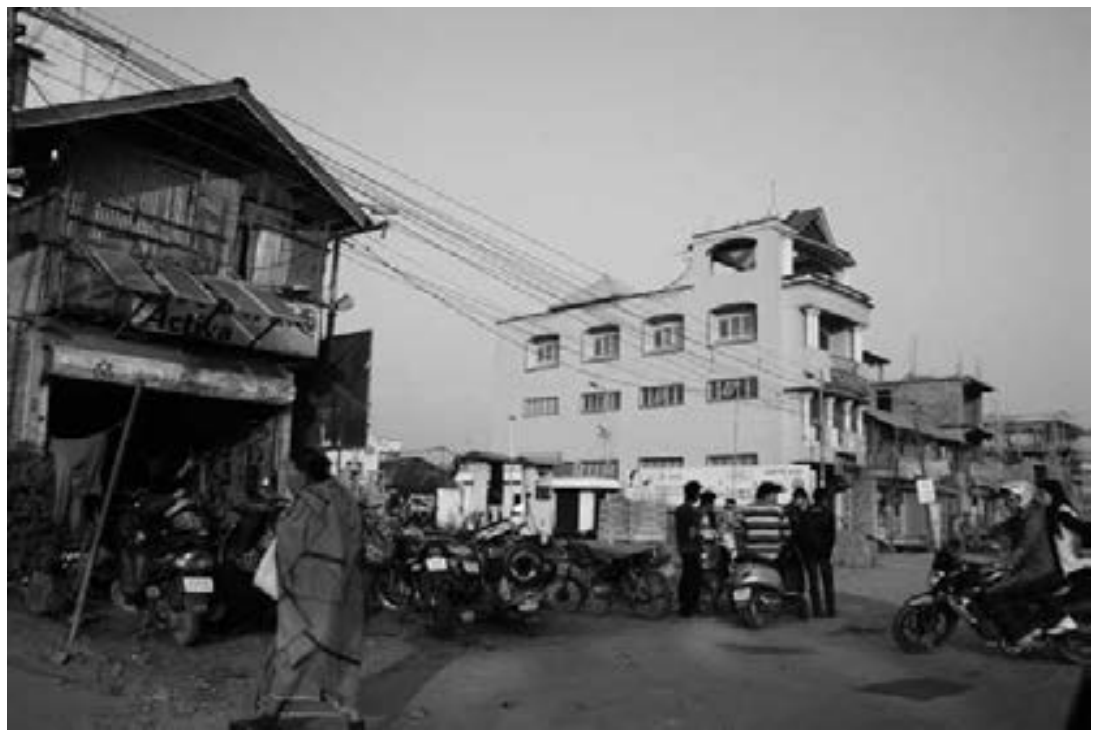

photographs of mansions from abroad, the use of building contractors rather than architects, materials of questionable durability, and inexpensive labour from outside the city all intended to 'demonstrate power through confections that bear little reality to tradition, aesthetics or living requirements' (2008: 36). Though I am more hesitant, and less qualified, to pass judgement on the aesthetics of the equivalent style of construction in Imphal, the social, political, and economic dynamics that produce it are comparable. Construction must also be considered with reflection on the destruction that has taken place in the city historically, and in living memory through the Second World War, occupation by the Indian state, and interethnic violence.

Living among the cottages, makeshift houses and shacks, concrete mansions, and layered multi-storey buildings featuring floors made of bricks, cement, timber and corrugated iron - often all in the same building, and amidst the lack of reliable services like water, electricity, and waste collection, not to mention the lack of street lights, public space, and drainage - contributes to a kind of shared melancholia about progress and soul searching at the social costs of development. Residents lament the loss of knowledge of traditional architectural styles, particularly the yumjao, and the alienation produced by high outer walls, watchtowers, security 
guards and the disappearances of trees, ponds, and wild animals. This is challenged in the ways residents seek to make place though small-spaces and the alternative, and rebellious, uses of existing spaces that will be discussed further below.

Neighbourhoods also provide a sense of safety in contrast to the insecurity experienced in the militarised environment 'out there' in the rest of the city. On the one hand the capacity of neighbourhoods to provide a sense of safety is limited in a city where the armed forces can enter any household at any time. On the other hand there is a sense among residents that they are better off in a familiar place than in another part of the city where no one knows them. As with the description from my afternoon in Keishamthong Kabui Khul that began this chapter, my companions were nervous about being caught by the armed forces in a neighbourhood where they didn't live, one where no one knew them and where no one remained on the streets to witness an act of violence, corruption or arrest. During patrols by the armed forces some residents would retreat indoors or into their compounds. In other places people just carried on with their everyday lives by socialising, drying clothes, collecting water, playing football, and shifting goods in and out of sheds. When I asked about these different responses residents pointed out that they were more cautious if there had been recent trouble in their neighbourhood or if a family member had recently been questioned. If the neighbourhood was a known place for a certain underground group and that group had recently been responsible for an attack or agitation, even outside Imphal, then there were more patrols, more questioning, and sometimes residents (usually young men) were arrested. At other times patrols were routine and people hardly seemed to notice.

\section{Alternative Places}

Residents also produce sites where these boundaries are transcended and belonging is sought, and felt, in alternative places. These are places for a different kind of belonging, one that skirts the divisiveness of the disturbed city and the ethnically demarcated distinction between neighbourhoods and reflects the social practices, and the dialectics that produce place discussed in chapter 1. Locating and analysing such places is difficult because the landscape of the city provides a lot of potential sites and a lot of false starts, as it were. For instance, the existence of a space in the city where members of different ethnic communities gather regularly and peacefully may appear as an example of such a place: such as Indira Park, Thangal Bazaar, or a 
restaurant (the pan-ethnic appeal of fried chicken holds the most potential). Imphal has so few public spaces to begin with that it is tempting to latch onto such sites and celebrate apparent plurality. Yet from time spent in these spaces it is apparent that distinctions between communities can be affirmed, interactions can be instrumental, and belonging is heavily dependent on who else shares the space at a particular time. With these limitations in mind, what then would constitute transcendence? What kinds of places would qualify as meaningful examples of sites where ethnic, class, and gendered boundaries are dissolved, even if only temporarily? Where do people seek and find belonging in Imphal outside their neighbourhoods, outside ethnically defined communities?

I will propose three examples, which while far from exhaustive are perhaps the most fascinating for what they say about the city and the borderland more broadly. First is the Khuman Lampak Sports Complex. Upgraded for the $30^{\text {th }}$ National Games in 1999, the complex is one of the few safe open spaces in the city. The construction of the sports complex and the village built to house the athletes was a major undertaking that transformed the landscape just to the northeast of the Kangla Fort along the Imphal River and in the northwest of the city at Lamphelpat. Hosting the games is confounding at a certain level given the poor security situation in Imphal and the rest of the state at the end of the 1990s. In the year prior to the games there were violent clashes between Kuki and Paite communities in Churachandpur District which killed over 200 people, in Imphal itself armed forces personnel were abducted by underground groups, armed forces personnel were 'accidently' killed by other armed forces personnel while travelling in a car, the leader of the Kangleipak Communist Party was killed by security forces leading to a five-day bandh (a general strike usually enforced by non-state actors), a large explosion targeted a former finance minister and a high-ranking official of the Manipur Rifles (his son) very close to the Khuman Lampak complex, and a 'trial' of the ban on Hindi cinema and music as well as the first stirring of the 'territorial integrity' movement which would escalate in 2001 driving a wedge between Naga and Meitei communities all shook the city. The literature on cities and major sporting events analyses the desire to appear 'on the map' by hosting such spectacles (Cornelissen, 2010; Klauser, 2012; Shin, 2012). Black (2008) argues that hosting of 'second order' sporting events is a strategic response to globalisation. Major sporting events are an opportunity to showcase modernity, attract capital, and in the case of cities recovering from conflicts or other calamities, to demonstrate stability and safety (Van der Westhuizen, 2004). They are also an opportunity to redevelop and reorder 
the city, a constant theme in analysis of the 2010 Commonwealth Games in Delhi (Bhan, 2009; Dupont, 2008). The hosting of the 1999 National Games in Imphal reflects the same dynamics albeit on a smaller scale. Hosting the games was a chance to demonstrate to the rest of India, and perhaps the region beyond, that Imphal was a modern, developed, and stable city - none of which were particularly evident then or now. It was a chance to be on the national map, instead of being considered a violent and separatist border city; Imphal was able to perform a deeply symbolic embrace of the nation, one at odds with the prevailing currents of local political life. At the same time there was the opportunity to perform Manipuri culture, defined fairly narrowly, for a national audience, to hammer home the point that Manipur is different but also a willing part of the nation. Further, bidding for and being awarded the games enabled the Manipur Government to demonstrate loyalty and use this to leverage further resources to actually build the necessary infrastructure to host the games, with large grants coming from central government bodies like the North Eastern Council (NEC) and the Ministry of Development of North Eastern Region (MDONER).

At first glance the now 15-year-old complex appears a shabby mix of construction debris, makeshift shelters, and dilapidated sections of buildings. Indeed the Manipur Planning Department has lamented the lack of central government finance to upgrade the facilities (2012: 155). Yet the complex is a hive of activity, especially in the early morning. On a cold December morning in 2012 children and young adults from Manipur's different communities could be seen jogging, stretching, and training for various sports in the fog. Almost all wear the ubiquitous training tracksuit with 'MANIPUR' emblazoned on the back - in various shades. Billboards in the complex feature famous Manipuri athletes, including London Olympics Bronze Medallist Mary Kom, a boxer from the tribal Kom community. Manipur has been very successful at producing athletes and sport is increasingly discussed as a path to integrating Manipur into national fold and as evidence that the borderland can contribute to the nation; a counter to rebellion (McDuie-Ra, 2015). At the local level sport is one of the few ways that a pan-ethnic Manipuri identity is constructed. At Khuman Lampak, athletes from all over the state come to train. Many are housed in nearby dormitories and have their costs paid by the Manipur Government. Manipur sporting teams comprise of members of all the state's ethnic groups. Given the centrality of sport for the production of identity locally and for the ways Manipuris are viewed in the national fold, sport, and the spaces where sport is played transcend hardening ethnic boundaries. Residents of Imphal also come to the complex for organised 
competitions and to exercise. The sheer number of people using the complex is remarkable, especially when one considers the circumstances of the disturbed city.

Respondents pointed out a number of reasons for so much interest in sport. Parents and social organisations encourage sports to try to keep young people 'off the streets' and away from underground groups and out of the path of the armed forces. Despite the insecurity of everyday life in the city and in villages and towns outside Imphal, children are encouraged to go out and play. There are a lot of former athletes working as coaches and running training academies that recruit children and youth to train for state teams. For such a dysfunctional city there is a surprising abundance of sporting associations at various scales. The city lacks spaces to play, hence the convergence on Khuman Lampak, though residents certainly improvise on makeshift patches of land on riverbanks, in schoolyards, and in fields on the edge of the city. Related to this, Manipur has a serious narcotics problem owing to unemployment, posttraumatic stress, and narcotics trafficking through the state (see Kermode et al., 2009). Sport is used extensively in rehabilitation from narcotics addiction by the scores of rehabilitation clinics in Imphal. Furthermore an interest in sport by children and teenagers is a way of avoiding narcotics addiction through distraction. The boom in after-school tuitions has challenged this somewhat, but sport still has a social position across class and ethnicity that is uncommon elsewhere in India. It has a social value that can even counter the wayward influences rife in the disturbed city. Finally, sport is a pathway to employment. This includes successful athletes being able to make a living but more importantly for the opportunity for recruitment into the state police and other government posts. For instance, Mary Kom has long held a post in the Manipur Police and is promoted each time she succeeds on the national and international stage. She is not actually in the police force, but it is a title and a pension that she will be able to use in her post-boxing career. This is not restricted to famous athletes and sport has become a pathway into all kinds of jobs and is encouraged as way to make things happen in a context where conventional pathways can be blocked. This is especially attractive for members of poorer families unable to send their children outside Manipur for education. At the Khuman Lampak pan-ethnic belonging is felt provided one is capable of participating in sport. This does not negate ethnic identity, but enables pan-ethnic identity to exist, even if only for a limited period.

Second are places for expressions of popular culture. Imphal youth draw heavily on cosmopolitan influences from East Asia and the West, in 
Image 2.3 Manhunt billboard, LIC Point

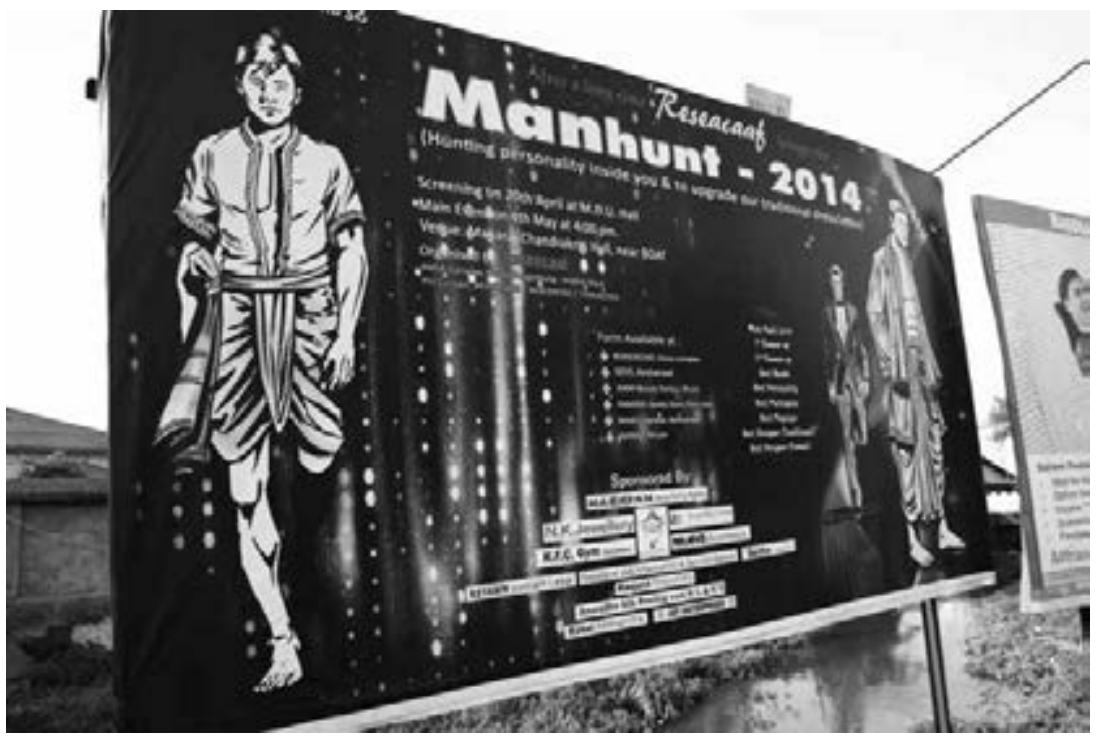

part to demonstrate divergence from Indian popular culture (Bollywood, cricket etc.) and in part a result of consumption of Korean, Japanese, and American music, film, art, and street culture (McDuie-Ra, 2012a: 166-76). Land connectivity to Myanmar over the last two decades has brought new flows of fashion into Imphal and many locals run fashion shops selling clothes brought across the border from China, Thailand and beyond. There are second-hand clothing stalls all over the city selling used items in similar styles. Popular culture is enacted at beauty contests, fashion shows, singing competitions, rock concerts, video halls, and more impromptu uses of urban spaces for breakdancing, skateboarding, and BMX biking. The conventional catwalk style fashion show is a staple of public events in Imphal. Yet there are notable variations including Manhunt, a catwalk show for male fashion, which includes a 'traditional dress' section and fashion shows specifically for transgender designers and models, which, to an extent, challenge the marginality of the transgender population in the city. There is also a thriving local theatre, literature and film scene. Some of these events are enacted in spaces created by the civilian government to promote distinctive Manipuri cultural activities to be performed for visiting dignitaries and the alwaysabout-to-boom tourism sector. Others are crafted in a more impromptu way. These are places where youth gain a sense of belonging that does not rest on ethnicity. They create an alternate everyday - one based around 
desires and aspirations connected to the outside world. However, while such places stand out in the urban landscape they are limited to mostly middle and upper class youth who can afford to participate. Thus, while ethnicity is transcended, issues of class remain.

Third are places for breaking alcohol and food taboos as described at the start of the chapter. These are overwhelmingly male places, yet they are places that transcend ethnic boundaries and where some urban residents escape the often-stifling atmosphere of neighbourhoods and households. Campaigns by the Meira Paibis against alcoholism and domestic violence in the 1980 s led to the Manipur Liquor Prohibition Act 1991. The ban is enforced by the Meira Paibis, who will often publically identify and shame drinkers, and the state police, who tend to enforce the law to extract bribes and fines. Members of the armed forces are exempt from the ban and often re-sell alcohol to shops and connected individuals. Alcohol is also purchased at border markets and smuggled into the city. While alcohol is available in some restaurants, these are generally easy targets for enforcing the law. Though in the bowels of the main market area there are many small establishments where alcohol is easily available and openly consumed. On one occasion I even saw a table of police enjoying some whiskey on duty. To avoid both legal and social surveillance many would-be drinkers head to private houses that double as drinking dens. During fieldwork I spent time in several drinking dens in different neighbourhoods, usually as a guest of a regular at that particular establishment. In this way I was able to gain a sense of when and why people go, what they do there, and who they know. Drinking dens are common in tribal neighbourhoods where there is a more tolerance to drinking among the community and less common in Meitei neighbourhoods where surveillance is more likely. However, regardless of location the patrons will usually include men from various ethnic groups, often eating and drinking together. These drinking dens are also where members of the different communities break various food taboos they would not be able to break in their household, especially consuming meat. In certain drinking dens sex is available, but sex work (also illegal) is more common in dedicated brothels and hotels in the main market areas. Drinking dens are where bonds are forged across ethnic divisions and respondents would often identify friends they have made through drinking. These friendships can be utilised in hard times. While men engage in this kind of camaraderie women are expected to uphold traditions and cultural norms; exacerbating tensions between men and women. Thus, in these places men experience a sense of belonging garnered through 
shared imbibing of alcohol and distance from the sites of responsibility and acceptable behaviour.

\section{Conclusion}

Imphal is a plural city. Its plurality is relative and needs to be understood in the context of the hill-valley binary as a dominant frame for understanding Manipur - a frame that suggests the city is a predominately Meitei city as part of the valley. Further, in other borderland polities in the Northeast, cities have tended to be created - or significantly expanded - following political agreements to create federal states and autonomous districts for particular ethnic communities. Imphal has a long history of habitation by different communities. It has a plural past often denied in analysis that reproduces the hill-valley divide. Decades of violence in Manipur have pushed more migrants from the hills and from surrounding borderland polities to the city seeking safety, work, and to attain skills. The opportunities for work in construction and trade brought on by a building boom financed through remittances, corruption, and transfers of Indian Government funds to stabilise the frontier city have also attracted migrants from other parts of India and neighbouring countries. Within this patchwork of communities living in close proximity, neighbourhoods are crucial sites for making place; for establishing a sense of belonging necessary to survive in a city where being caught by the armed forces or underground groups in an unfamiliar neighbourhood engenders deep anxiety. Neighbourhoods are commonly formed on ethnic lines, lines that dissolve at times but are enforced at others. Yet ethnicity is transcended, even if temporarily, in alternative places ranging from a sports complex to sites for performing and consuming popular culture to illicit drinking dens. In these places residents seek out belonging based on identities adjacent to, and sometimes in contradiction of, ethnicity. The following chapter analyses the ways different actors state, non-state, and quasi-state - control parts of the city and the ways control is challenged from below. 



\section{Control}

The Lai Haraoba, the 'pleasing of the gods', is a pre-Hindu festival said to be at the 'heart' of Meitei culture and worldview (Parratt and Parratt, 1997:xiv). The festival involves dance, music, oral poetry, flowers and other offerings, and spirit mediums that channel la $i$ - female and male deities that are sacred and numinous. The Lai Haraoba is performed to honour these deities at the village and neighbourhood level, a rich cosmological and transcendental experience that I won't even attempt to describe (See Parratt, 1980; Parratt and Parratt, 1997). In May 2014, the month of Kalen in the Meitei calendar, I was invited to attend a neighbourhood Lai Haraoba with my friend Anya and her family at Ima Khunthokhanbi Shanglen, a laishang (temple) on the edge of the DM College campus close to the centre of the city. It was the final day of the festival, Lairoi. A large crowd thronged on the road inside the campus where stalls had been set up adjacent to the temple. It was night when we arrived but the area was lit up beautifully. The state security forces were present, guarding the entrance to the college campus. I had been leant appropriate clothing for the festival and settled down on the ground to watch the Ougri, a part of the sequence of performance on Lairoi.

Transfixed by the spectacle, I was startled when one of the elders of the locality tapped me on the shoulder and invited me to shift to another spot with a better view. Uncomfortable with this idea, I conferred with Anya who suggested it was easier to accept than decline. I was placed next to a non-Manipuri who began a conversation about my origins and my purpose for being at a neighbourhood Lai Haraoba. I asked a few tentative questions in return, conscious of the security personnel that loomed behind us. $\mathrm{Mr}$ Joseph was from south India. While taking photographs and shooting video of the Ougri, he replied enthusiastically that he had recently arrived in Manipur as a member of the armed forces to work in external relations. He had been posted all over the country, including Kashmir, a fact few armed forces personnel fail to mention. I disclosed that I was researching the city and this included understanding the role of the army. This seemed like a very good idea to Mr Joseph. 'People must know the truth!' he exclaimed, before telling me that there was too much misinformation about the armed forces, a problem he planned to fix. I asked if this was a difficult job given the behaviour of the armed forces in Manipur over the previous decades. 'No,' he replied, 'Good people know the truth. And now we have social media also'. 
After bidding farewell I joined my friends to cover the short distance to their house. Anya recognised Mr Joseph from the media and started to tease me about my newfound 'military connections'. I gave a recap of my conversation with Mr Joseph and asked whether she thought he would have much luck in his campaign to improve the image of the armed forces. Anya continued chewing sunflower seeds and spat out the husks as she replied. 'They have no idea what people think of them,' and she added that they only meet with government people and occasionally some well-vetted NGO representatives. 'So why come out to be among the people on Lairoi?' I asked. Anya agreed this was an unusual move and added that in past years there is no conceivable way that someone working for the military, even in a civilian role, would be allowed to venture out at night to a neighbourhood festival given the risk of attack. I asked whether this meant Imphal was now safer than it had been in recent past. Anya rolled her eyes, 'safer for them!' she said pointing at a cluster of armed forces vehicles making their way along the road.

This chapter sketches the prevailing spatial order that has emerged since the city was declared disturbed in 1980 . It is concerned with a set of simple questions: Who has the power to control urban space in Imphal? Who can enable and deny place? How does this manifest on the urban landscape? Focusing on space and who controls it, or attempts to control it, provides an illustration of fragmented sovereignty in the disturbed city where space is controlled and contested in microsites; a street, a neighbourhood, a corner, a memorial, a hill. The previous chapter was concerned with belonging, on the places where resident feel safe and where they enact identities - in expected and unexpected ways - in contrast to the disturbed city 'out there'. This chapter is concerned with the city 'out there', while also being wary that the distinction between the 'out there' of the city and the 'here' of places of belonging is continually dissolved in the disturbed city.

I begin the chapter by outlining the spatial practices of the armed forces, civilian government, and non-state actors arguing that the armed forces control space through security, the civilian government through development and planning. Underground groups and residents fill, and create, the gaps in between. In the second and third sections I illustrate this diffuse hegemony - and attempts challenge it - though memorials that mark Imphal's landscape. Memorials to the lives of those lost in conflicts, whether against the British, against India, or between communities, mark the landscape of Imphal. They demonstrate the desire of different actors to produce and control memory in the city and in turn mark the urban landscape with symbols representing different groups, conflicts, movements, and moments 
in the life of the city. I will focus on resistance and nationalism, insurgent memorials, and the burgeoning industry in visiting memorials to dead foreigners from the Second World War.

\section{Spatial Control in Imphal}

Spatial control in Imphal is fragmented, a prime example of the ways non-state actors 'crosscut or superimpose themselves on the territorial jurisdiction of nation-states' (Ferguson and Gupta, 2002: 996). In much the same way as ethnically composed neighbourhoods discussed in the previous chapter, there is a temptation to think of the city as divided into distinct zones of control - some run by the armed forces, some by the civilian Manipur Government, some by underground groups, and some wherein control appears absent. While helpful to a degree, it is important to iterate that control of such zones is never absolute, and the boundaries of these zones shift constantly in response to the ways space is contested in the city. As Gazit has argued in the case of the Occupied Territories, 'the efficacy of a state's power during contested political circumstances is shaped not only by formal and internationally recognised sovereignty but rather generated by a series of interactions among social actors in and through the occupied space' (2009: 84). This is certainly true of Imphal, where spatial control is affirmed by different actors at different times, overlaps in some sites and dissolves in others. Even in sites where control appears firm, such as paramilitary barracks, bomb blasts, civic pressure to relocate, and even dissenting graffiti on the walls suggests some volatility. With this disclaimer in mind, I will outline the prevailing order of spatial control in Imphal by focusing on the armed forces, the civilian government, and non-state actors in turn.

\section{The Armed Forces}

The armed forces have the power to erase place, disrupt rhythms and rituals, regulate, and impose law and order; which in the disturbed city includes killing, torture, and abduction. They also have the power to enable, or at least permit, some of the activities that help to enable the rituals and rhythms of everyday life. Simply put, they are intrinsic to the ways space is controlled.

Headquarters and barracks for various armed forces are situated throughout the city. As the city has grown residential areas now surround 
some barracks, such as on the hill at Singjamei in the city's south and at Chingmeirong on the northern edge of the downtown area. Others, like the enormous Central Reserve Police Force (CRPF) complex at Lilong, in the city's west, remain relatively isolated from the rest of the city. Some barracks have been moved, such as the Assam Rifles Inspector General headquarters from the Kangla Fort in 2005, and the relocation requires farmland and new infrastructure, expanding the city in various directions. Smaller posts exist on main roads, street corners, bridges, outside public buildings, the airport (fully administered by the CRPF), banks, major hotels, and certain religious sites. Checkpoints are set up on main roads transecting the city and the main roads out of the city. Armed personnel patrol on foot and in vehicles through markets and residential neighbourhoods.

Different army, paramilitary and state police forces ('armed forces' hereafter) have different territories and responsibilities. These are divided into forces under central command - answering to the Indian Government, and those under state command - answering to the Manipur Government. Such is the paternalism between the centre and the borderland that an appointee from Delhi heads some of the forces under state government command. For instance, a senior ranked member of the Indian Police Service heads the Manipur Police Force. Forces under central command are under the extraordinary provisions of the AFSPA discussed in chapter 1 . Despite 'disturbed' status being lifted from Imphal in 2004, the various central and state forces remain in the city. State forces do not operate under the auspices of the Act, however; they operate in what I have termed elsewhere 'the frontier culture of violence' that persists in the borderland (McDuie-Ra, 2012b).

The distinction between central and state forces is also an ethnic distinction; the former staffed by non-Manipuris and the latter by locals. The central forces are experienced as an occupying force. Most conspicuous are the Assam Rifles, the oldest paramilitary force operating in Imphal under the authority of the Ministry for Home Affairs in Delhi. They have been in Manipur since before Indian Independence, the 1949 Merger, and the creation of the state government. Also conspicuous in the urban landscape guarding public buildings are the Central Industrial Security Force (CISF) and the CRPF, both under central command and composed of recruits from outside Manipur.

State security forces are made up of members of Manipur's ethnic groups, though indigeneity does not equate to popularity or legitimacy. Rather than an occupying force from India the state security forces represent the militarisation of law and order at the local level, particularly the Manipur 
Image 3.1 State Police at Thangal Bazaar

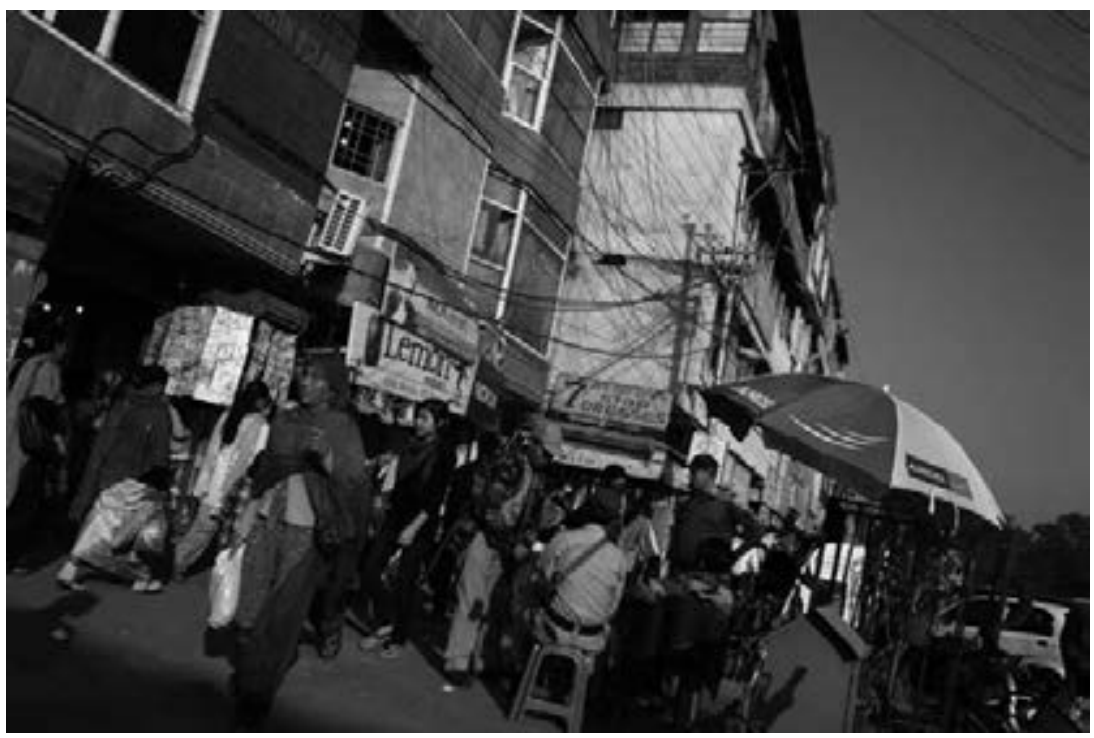

Rifles and Manipur Commandos. Personnel from these forces can often be seen wearing face masks obscuring their features lest they be identified and subject to retribution by members of the public and underground groups. The Manipur State Police undertake more of the mundane actions controlling what happens in different parts of the city, such as evicting illegal vendors, raiding premises serving alcohol, enabling and denying access to sensitive locations, and traffic duty. Some of these tasks are left to the Village Defence Force (VDF); voluntary militias armed by the Manipur Government to provide security in villages and neighbourhoods.

The VDF are an interesting case and worth a brief aside to demonstrate the ways in which armed groups are created by the state to assuage the threat of other armed groups. The force was created in 2009 and initially 1550 volunteers were recruited. The VDF was created in response to calls for protection from underground groups in Heirok village outside Imphal, but was then expanded as a youth unemployment strategy modelled on a similar system in Kashmir. VDF members are entitled to a 3000 Rupee honorarium minus ration fees (about \$6o USD) per month. In the five years since they were created, members of the VDF have been arrested for black market activities, smuggling, car theft rackets, extortion, and they often appear in the media for bumbling exploits like accidental shootings and amateurish attempts at organised crime. 
During fieldwork I encountered many VDF personnel. They patrol neighbourhoods in plain khaki pants and shirts, some wearing boots and others rubber sandals. Most have an aged 303 rifle over their shoulder though some get by with just a bamboo lathi. They tended to stay out of the way of other armed forces, coming around after other patrols had moved on. Off-duty VDF in plain clothes would be pointed out to me in the neighbourhoods. One could see that they carried a certain status, though not necessarily much admiration. Residents have responded to VDF vigilantism and there have been several cases of VDF members being beaten and killed by other civilians. Though mostly perceived as a menace that provides very little security for anyone, and as a somewhat comical footnote to the story of militarism in the disturbed city, the VDF have taken strike action demanding better pay equivalent to the police force. They have formed their own welfare association and held sit-in protests, bandhs, and a rally at Keishampat Junction in 2013 , the latter of which created one of the more bizarre scenes in Imphal's street protest history; a hundred or so men in khaki uniforms marching while being guarded by around the same number of men in khaki uniforms (though carrying weapons) on one of Imphal's main downtown streets. In 2014 the film VDF Thasana, a comedy about an honest VDF volunteer played by one of Manipur's most famous actors, Bonny Sharma, was showing across the city. The lead character, Thasana, turns to the VDF after failing to find other work and bumbles through life and love. The phrase 'VDF Thasana' has become a popular term referring to the hapless and tragi-comic exploits of the real VDF.

From the members of the Assam Rifles drawn from as far away as Tamil Nadu in south India or Rajasthan in the west to the VDF officers from the house next door, the spectrum of armed personnel in Imphal is vast and they impact urban space in many ways. I focus on two here that have the deepest impact in everyday life. First, mobility is obstructed and redirected by encounters, and the possibility of encounters, with armed forces personnel. Some residents go to great lengths to avoid such encounters by taking circuitous routes or staying home. Young men are questioned about association with underground groups and wanted or recently apprehended operatives. State security forces also harass young men about their appearance, their friends, and accuse them of being drug or alcohol addicts. Manipur's interethnic tensions are also at play in these encounters and members of Kuki and Naga communities are often accused of being members of the relevant underground groups. Respondents reported that this was even worse if their skills at Meiteilon (Manipuri language) are below proficient or they had a strong accent. For non-Manipuris these encounters 
could be even more charged, even if those in question were born in the state. These encounters are designed to intimidate and then extract bribes, but they also have an odd social and moral policing component. Needless to say they have a lasting effect on young men moving about the city, or simply passing through, trying to leave the state or return home.

For women these encounters are to be avoided wherever possible. Extreme sexual violence committed by the armed forces (and by underground groups) has a disturbing legacy in Imphal (see Goswami et al., 2005). Women avoid routes where they might be harassed and an encounter can escalate into violence. Public vehicles provide a modicum of protection, but many women are wary of riding in them without other passengers or if the driver is unknown to them. Older women tend to be more mobile, in part owing to their place in the social and political culture of Manipur and especially in resisting the excesses of the armed forces. There are class elements to this, too. Women and men able to travel in private cars usually have better mobility when compared to those who travel on foot or on bicycles and motorbikes, although cars too are stopped and sometimes fired upon. Couples face their own challenges as the moral policing culture of Imphal sees men and women riding together on motorbikes and in cars stopped and asked questions about their relationships. From dusk the lack of street lights and the sporadic power outages make the city very dark and few people venture onto the streets in the evenings, unless they have their own cars or are in the confines of a familiar neighbourhood.

When I began research in Imphal I used to record these stories of obstructed mobility. By my second stint of fieldwork it was clear that these stories are so common that it was more difficult to find anyone without a story of encounter with the armed forces. Some stories were banal, just part of everyday existence in the disturbed city. Some were tragic, involving family members that never returned. Some involved personal experiences of violence, corruption, or blackmail. All suggested that the armed forces controlled the city; at least enough of the city to impinge upon everyday decision-making and mobility. Each encounter can leave residents having to pay a 'fine' or make a 'donation' to the personnel at the checkpoint. These may appear to be minor inconveniences, yet they affect choices residents make about mobility and the mobility of family members (especially women), and each encounter has the potential to escalate.

Second, and closely related, the presence of armed forces on the streets and in neighbourhoods provokes fear and anxiety. Violence by the armed forces is widespread and even those who have not directly experienced it usually know a relative or friend who has. As the armed forces can enter any 
premises without a warrant they collapse any distinction between public and private space. Violence includes executions, rape, battery, torture, and disappearances (HRW, 2008; Dobhal, 2009). Few of these incidents capture broad public attention, however, two incidents in the last decade made national and international headlines and had an impact on the ways space is contested in the city itself: the 2004 abduction, rape and murder of Thanjam Manorama Devi by the Assam Rifles and the 2009 execution of Chongkham Sanjit by the Manipur Commandos. While the Manorama case is better known, the execution of unarmed Chongkham in broad daylight in one of Imphal's busiest market streets brought public anxiety to new levels. Chongkham's execution was captured by a photographer and published in a national news magazine, Tehelka (Rehman, 2009). Respondents often mention the Chongkham incident as evidence of chronic insecurity and elusive justice. The spot where he was murdered is unmarked. Armed forces personnel patrol the area throughout the day, when it is crowded with people, and night, when it is empty save for trucks loading and unloading goods. As I was often told when Chongkam's murder came up in conversation, if it could happen at that spot in 2009, when attention to human rights abuse by the armed forces was far greater than in decades past, and with AFSPA lifted, then it could happen anywhere at any time.

Physical proximity to the armed forces exacerbates fear because of frequent attacks on barracks, posts and patrols. For example, over a 30-day period from October to December 2012 - a period when I was in Imphal - local press recorded ten explosions targeting armed forces posts claimed by four different groups. This does not include explosions aimed at other targets or those outside the city. This was a period with no major agitations or inter-community conflicts that might increase the frequency of incidents. It was, for Imphal, just a 'normal' season. Residents are often caught in these attacks or face retribution by the armed forces searching for the perpetrators afterwards.

The armed forces counter their poor reputation by advertising episodes of community service in public spaces. At the State Bank of India branch in Thangal Bazaar there is a bunker built into the front of the building staffed by members of the CRPF. The bunker has camouflage netting, iron bars, and a small door where customers can enter into the bank one at a time. Along the external wall of the bunker and facing the busy street are a series of newspaper clippings enlarged to poster size showcasing recent community endeavours by the CRPF. These posters include the following headlines: 'CRPF observes world environment day 2012' with a photograph of CRPF members planting tree saplings, 'CRPF honours Md. Ismat All-India Class 
12 Topper' with a photograph of a successful local student being awarded a certificate at the CRPF barracks, and 'CRPF aids injured man'. Similar public displays of community service can be found elsewhere in the city. Not only do these posters play a role in attempting, poorly, to shape public perceptions of the various armed forces operating in the city, they also demarcate and claim territory of the various forces: a building, a street, a lane, a park, a ward. In places the armed forces have no control such posters are swiftly removed.

\section{Civilian Government}

While the armed forces control parts of the city by enacting security, the civilian government controls parts of the city through development projects. As discussed in the previous chapter, the built environment of Imphal appears chaotic. This is a result of a number of factors. First, rapid population growth has increased density, leading to new informal settlements and to new construction in existing settlements (mostly vertical) to increase rental spaces for migrants. Second, endemic corruption in urban planning means that those able to violate planning laws and land boundaries usually escape penalty, resulting in oversized dwellings for those with connections and shrinking allotments and public land for everyone else. Third, monies gained from the illicit economy, illicit border trade, extortion, and corruption are laundered into construction, resulting in mammoth private dwellings alongside more modest ones. The remittance economy also furthers this phenomenon - so-called 'diaspora housing' throughout the city. Fourth, investments are often begun and then abandoned, owing to various factors from extortion to structural collapse (especially in the swampy soil of the valley) marking the landscape with half completed or disused buildings. Fifth, public works are a major source of contracts for developers and thus certain parts of the city are subject to constant 'improvements', such as digging up and relaying the pavement in downtown streets, whereas others lie neglected for years. Sixthly, insecurity results in high walls around many private residences and compounds (usually inhabited by an extended family) with steel gates and broken glass on top of the walls and watchtowers outside the houses of ministers and other high-ranking public servants, furthering the perception that the city is unsafe. Finally, the dysfunction of the local state, including the municipal authorities, leaves waste uncollected, damage unrepaired, and services inconsistent - especially water and electricity supply. This landscape reflects and exacerbates the inequalities produced by Manipur's politics. While the 
civilian government is implicated in the production of this landscape, it also seeks legitimacy by trying to impose order upon it.

Damage to significant public buildings through explosion and arson, such as the state assembly (2001, 2012), the state public library (2005), the public works department (2011), and the residence of the Chief Minister (2008), combined with the visible presence of armed forces, many under command of Delhi, depict a weak civilian government barely in control of the city. Similarly, the rundown and dysfunctional services escalate grievances against the civilian government among residents. Public works serve as a mechanism to instil some faith in the civilian government and address, or at the very least avert attention from, urban dysfunction.

The Imphal City Development Plan 2007 encapsulates the spatial practices of the civilian government. The plan seeks 'urban renewal' and notes, 'there is a strong need to develop physical infrastructure. At the same time, the growth in population places a severe strain on urban amenities and infrastructure such as housing, public transport system, water supply, solid waste collection, sanitation and sewer systems. Unplanned development leads to unplanned growth and clustered settlements' (Imphal Municipal Council, 2007: 5-6). Thus far it has proven far easier to dismantle unplanned settlements than improve amenities, though new settlements are appearing all the time as will be seen in chapters 6 and 7 . Within the plan is the stated desire to ensure Imphal befits its status as a state capital. In the years since the plan the Manipur Government has commissioned several major public works to construct a modern and orderly capital, including the disastrous Bir Tikendrajit Flyover (2007) built to a quarter of its intended width, the new market complex (2010), the new State Assembly (2013), and the Manipuri Film Development Corporation Complex, Cultural Complex, and Convention Centre (2012/13).

Two of these 'showcase' developments warrant brief attention. The first is the rebuilding of the city's main markets in a two-storey roofed complex in the centre of the city. The three buildings housing the markets have neo-traditional Meitei roofs echoing the architecture of Southeast Asia and locating Imphal between South and Southeast Asia - a manifestation of its recalibration as a gateway city between South and Southeast Asia. Most tribal traders were not given places in the new buildings and were instead moved to a the 'Tribal Bazaar' at New Checkon - a site further away from the centre of the city and the main junctions where goods come in from the countryside. Meiteis were granted the showpiece development at the heart of the city connecting the market to an historical polity and a unique architectural form, while tribals are sent to a less desirable location and a 


\section{Image 3.2 Bir Tikendrajit Flyover with the Ima Keithel behind}

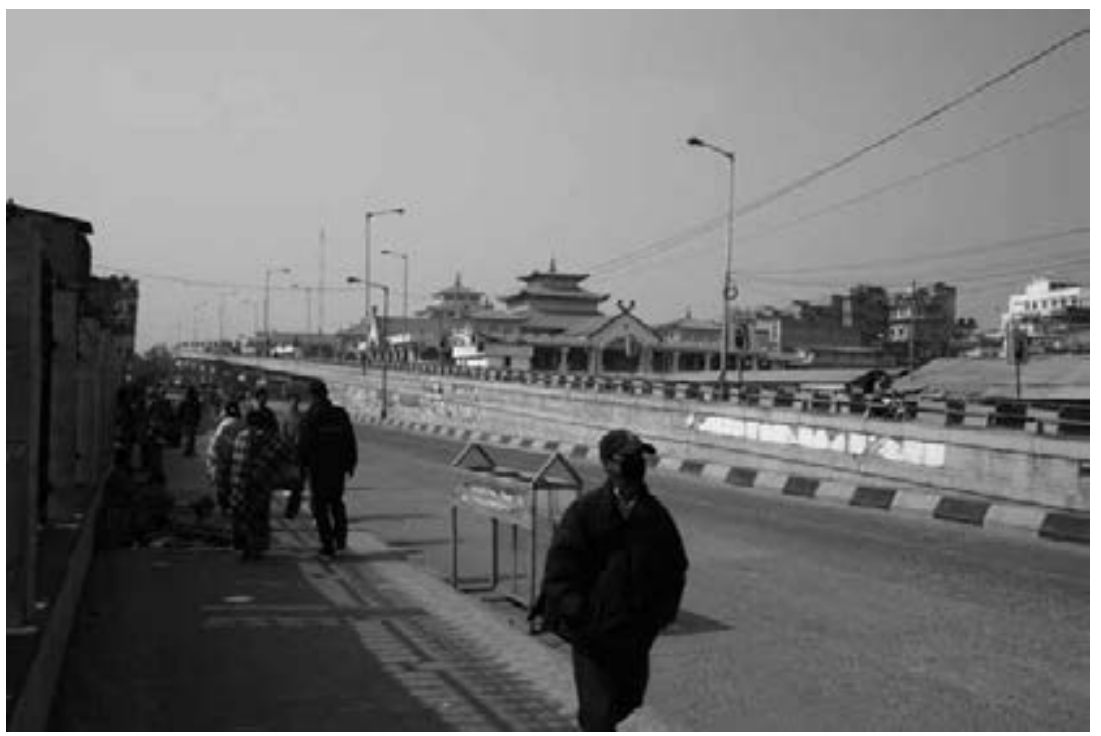

separate market. Cases like this are used to equate the civilian government to the interests of the Meitei population. Many vendors, including Meiteis, tribals, Pangals, and mayangs (non-Manipuris) sell their wares illegally on the pavements, staircases, and 'gullies' around the Ima Keithel. This is a popular spot for crackdowns by the Manipur Police and VDF, who clear (or threaten to clear) the area every hour or so with loudspeakers and lathis. Vendors, mostly all women, gather their wares and run to safety around a corner. They are rarely pursued, rather police wait until they return and then extract bribes. This compromise can benefit both sides, though vendors are highly vulnerable to repeated requests each day from different authorities. Unlicensed traders have also occupied other spaces in defiance of the civilian authorities' attempts at spatial control - including permanent occupation of a nearby market area created to temporarily house licensed traders during the renovation of Ima Keithel.

The second is the construction of the new legislative assembly. A modern capital helps to counter the image of Imphal as chaotic and lawless while also putting the city on par with other state capitals in India. The new state legislative assembly is a modern building for a modern polity, further reflecting the desire to put the city on the map as with the National Games in 1999. The assembly holds some 500 staff; the grand, domed building in three connected segments with blue-tinted windows and a shallow pool 
out front, reflecting the building on clear days, is a staggering contrast to the haphazard construction in most of the city. The site provides a visual contrast between the bold statement of a powerful civilian government capable of steering Manipur into the future and the vulnerability of the same civilian authorities. The building is situated a considerable distance from surrounding roads to avoid the sort of grenade attacks that damaged the previous assembly. Watchtowers are located along all the high walls of the perimeter fence staffed by machinegun toting security personnel. There is a pedestrian path passing in front of the building, though an armoured vehicle with a gun mount is stationed there, dissuading anyone from walking along it.

Spatial control is enacted from the top down by the armed forces and the civilian government. While the armed forces control parts of the city by enacting security (occupation, violence, and harassment), the civilian government control parts of the city through development projects that seek to create order and patches of urban landscape befitting capital city status. Both undertake spatial practices to demonstrate that they have control over the city: control of movement, of territory, and of how and when space is used.

Spatial control by the armed forces and civilian government has not gone unchallenged. The most spectacular challenge was the naked protests by members of the Meira Paibis (Meitei women's association) in 2004 that resulted in the Assam Rifles vacating Kangla Fort. Kangla Fort is the geographic, historical and spiritual heart of Imphal, at least for the Meitei community, as the seat of the former kingdom and as a central element in Meitei cosmology (Ray, 2009). The Assam Rifles occupied Kangla after the British took control of Manipur in 1891 and thus its occupation is synonymous with British and then Indian colonisation. Given its size and location, residents of Imphal passed Kangla on their way in and out of the city and in the course of their daily lives. For several generations of residents, passing an occupied Kangla that they were forbidden from entering materialised their vanquished sovereignty. They were denied access but also had to witness the occupiers' visible control of the site, baring arms that meted violence on their own community and uniforms that granted immunity through AFSPA.

After the rape and murder of Thanjam Manorama Devi in 2004 by members of the Assam Rifles, a group of Meitei women from the Meira Paibis staged a naked protest at the entrance to the Kangla Fort, daring members of the Assam Rifles to rape them. The incident received coverage throughout India and abroad and has been the subject of exhaustive academic analysis in the decade since (Bannerjee, 2008; Bora, 2010; Chakravarti, 2010; Gaikwad, 2009; Misri, 2011). The naked protest and the events that followed offer a striking commentary on space and power in the city. The protests took place 
at the gate. The women could not enter because the fort was controlled by the armed forces delineating the boundaries of civilian space. Yet even to occupy the small area in front of the gate itself was a bold and courageous act. As respondents in Imphal often noted during conversations about the incident, the gate was not somewhere where residents halted. It was a site that you moved quickly past, preferably on the other side of the road. The attention received by the protests eventually led the Prime Minister of India, Manmohan Singh, to lift the AFSPA from Imphal and to return Kangla to the people of Manipur. An idea mentioned as far back as 1992 when the then Home Minister M.M. Jacob visited Manipur (Kangla Fort Board, 2009: 24).

As a public space, Kangla is now enjoyed by families, teenagers looking for privacy, tourists, and pilgrims - especially to sacred shrines within the compound. In a city of few public spaces it has become a focal point for leisure. Activists brought the occupation of the fort onto the national political agenda. However, it took the Indian Government in Delhi to remove the Assam Rifles. The civilian authorities, including the Manipur Government, played a very minor role, though the Chief Minister of Manipur since 2002, Ibobi Singh, has discussed the issue from time to time. The Assam Rifles still use Kangla, mostly as a shortcut for their vehicles to avoid busy traffic on the main roads that skirt its boundary, as there are several Assam Rifles posts in close proximity to Kangla and they have their own gate into the compound on its northern side. There is also a helipad on the site. They relocated their headquarters to several sites, the largest of which is in Mantipukrhi in the city's north.

In 2010 a replica of Kangla Fort gate was opened at the relocation site within the new Assam Rifles headquarters. At the unveiling the local press included a statement from the Assam Rifles claiming the replica gate 'is dedicated to the historical legacy of Manipur as well as a tribute to the glorious decades long presence of the paramilitary force in the state. It is a telling testimony of the selfless love and respect of Assam Rifles for the people of Manipur' (quoted in Sangai Express, 2010). The press photos show the high-ranking members of the Assam Rifles in uniform with their wives in saris, a very typical Indian dress, in front of the replica of the very same gate where the Meira Paibis protested. I mention this because the imagery depicts perpetual occupation. The Assam Rifles may have been evicted from the Kangla Fort through extraordinary civic activism after more than a century of occupation, but the imagery of that occupation is recreated at Mantipukhri, just 5 kilometres away. They have built their own replica Kangla that they can continue to occupy in their compound. Moreover, the recreation of the scene is accompanied by a press release that speaks of 'love and respect' at an event where men in uniform - the same uniforms 
that have terrorised the population - stand with their wives at a function attended only by the military establishment and their families safely within the compound, shielded from the city they claim to protect. The Assam Rifles are either unaware or uncaring of the symbolism. Such overt challenges to the armed forces are rare. Their control of the city is more often challenged in other ways: explosions, abductions of personnel, memorials and graffiti.

\section{Non-state Actors}

In Imphal the significant non-state actors are underground groups, ethnonationalist organisations, student unions, neighbourhood associations, and religious actors. They challenge spatial control of the armed forces and civilian authorities and make claims on various spaces in the city. Claims do not necessarily equate to complete control, though there are certain neighbourhoods and areas of the city where they 'run things'. More common is partial control, reflecting the fragmented sovereignty of the city and polity more broadly. It helps to consider the power of non-state actors spatially as in the precise locations non-state actors have influence and the locations where that influence wanes, in the realms of everyday life that non-state actors influence, and temporally as in when non-state actors have influence - in what circumstances and at what times of the day, month, year. In certain locations non-state actors deliver services, provide safety, and advocate for justice where civilian authorities lack the will or capacity to do so and where the armed forces are the source of insecurity. Further, it is not simply that non-state actors fill gaps left by the state; some of these gaps exist because of the strength, support, and legitimacy of non-state actors.

Non-state actors are not always distinct from the communities in which they are embedded or from which they originate. Most are membership organisations. These members also have friends, relatives and neighbours who may be supporters or opponents, or who may face very real dilemmas around the role of their friends and loved ones in various organisations. Some organisations are legal, some illegal. Some are legal but engage in some illegal activities and vice versa. Some cooperate with the civilian authorities and, on occasion, with the armed forces. Some are co-opted by one or the other on certain issues.

Neighbourhood associations are very well established in Imphal, especially among the Meitei community. Most prominent are the Meira Paibis (neighbourhood mothers' associations), who have been at the forefront of protests against the armed forces and also in movements to maintain the territorial integrity of Manipur, and various Nupi Lup - groups organised for 
collective action around particular issues. Members of other ethnic groups have their own neighbourhood associations, though ethno-nationalist organisations and/or underground groups 'stand in' for neighbourhood associations for the non-Meitei population of the city, especially those with a shorter history in Imphal.

Underground groups garner the most attention from residents and authorities and the expression ' $U G$ ' is frequently used to refer to people ('He is a UG'), places ('UGs are big here'), and causality ('It happened because of UG'). 'Underground groups' is a blanket term to describe armed organisations, some of which are active in nationalist and ethno-nationalist struggles, while others are involved in extortion, licit and illicit trade, construction, or patron-client relations with a range of people from political elites to singers to property developers. Ethno-nationalist organisations are 'above ground' actors who pursue the interests of their various communities through public activism. Some are tied closely to underground groups while others are more distant. Some have good relations with the armed forces, though there are so many different armed forces (central, state, volunteer) that good relations with one force, battalion, or command does not always mean good relations with another.

There are plain-clothes intelligence officers from Indian and Manipur intelligence, off-duty armed forces personnel, and incognito members of underground groups moving about the neighbourhoods and markets. When someone makes a demand on another resident for money, to follow them, to give them something, to sign something, to stay away from somewhere, many residents can never be completely sure whether the person making the demand belongs to one of these groups, or is well connected to one of them, is just an opportunist, or is a broker of some kind. During everyday encounters residents must contend with this ambiguity. As a result, residents prefer to live, work (where possible), and consume in spaces they know and where those making demands, and providing protection, are known or at least knowable as part of their ethnic or tribal community.

\section{Contesting and Co-opting Memory}

The armed forces control space through security, the civilian government through development and planning, and underground groups fill, and create, the gaps in between. When the distinction between space 'out there', controlled by the armed forces and civilian government, and the 'here', where residents find belonging, is dissolved, residents find ways to mark 
a patch of the city and construct an alternative narrative about its significance. Memorials made by residents, non-state actors, the armed forces, and the civilian government mark the landscape of Imphal, revealing the desire of different actors to signify moments in the life of the city. Indeed, the politics of memorial provide a snapshot of fragmented sovereignty.

There is a vast literature on landscape and memory. As Lowenthal famously wrote, 'The place of the past in any landscape is as much the product of present interest as of past history' (1975: 24). Present interests shape the landscape through symbols, constructing and evoking the past to reflect contemporary claims on territory, sovereignty, and state-making. These symbols can be recreated and replaced accordingly and can also be contested through protest, demolition, or the creation of counter-symbols and counter-memorials (see Legg, 2005). As Mitchell argues, 'both memory, and its corollary, forgetting, are hegemonically produced and maintained, never seamlessly or completely, but formidably and powerfully nonetheless' (2003: 443). Memorials thus serve as 'texts' that can reveal the interests, actors, and histories behind their creation; as 'arenas' where different groups debate and contest the meaning of the past and the future; as 'performance', places where rituals, festivals, civic ceremonies, public dramas are enacted and, at times, subverted (Dwyer and Alderman, 2008: 166). The tactics of producing identity out of memory and place are often similar whether enacted from above or below. As Hoelscher and Alderman put it, 'what subaltern and dominant groups share in their efforts to utilise the past is the near universal activity of anchoring their divergent memories in place' (2004: 349). The location, condition, and permanence of a memorial or monument suggests a position in relation to dominant narratives of the past and present and in relation to sovereign power in its various concentrations; concentrations that are fragmented, overlapping, and contested in Imphal.

There are official narratives of the past in Imphal, but official is not a singular narrative in the disturbed city. There are also unofficial narratives - rebel memorials as it were - and again there is no singular counternarrative 'from below'. All are subject to performances marked by 'bodily repetition and the intensification of everyday acts that otherwise remain submerged in the mundane order of things' (Hoelscher and Alderman, 2004: 350), including performances by state, quasi-state, and non-state actors making claims on the past and spaces where the past is materialised. Given the contentious nature of Imphal's politics, the fragmented sovereignty, and the physical density of the city, this makes for a fascinating interplay of politics in microsites of control and contention. 


\section{Resistance and Nationalism}

During fieldwork I was advised to visit certain memorials. Sometimes friends and acquaintances would take me to personally significant memorials or memorials they had noticed when they learned I was interested. Other times I was lucky; I would find a plaque or a statue or a pile of cement in a laneway, a neighbourhood, a wasteland. Some are relevant for this chapter, while others simply enriched my understanding of the city and the way its inhabitants celebrate, grieve, and mark the landscape with objects and words that signify claims on urban space; small pockets of belonging.

The largest and best-maintained monuments in Imphal are memorials to heroes of Manipuri resistance to external aggression. Across the IndoMyanmar Highway from the southern periphery of Kangla Fort is the Nupi Lal Memorial Complex. The complex features a marble mausoleum-style building at the top of a flight of stairs. A statue depicting three unarmed Manipuri women confronting two members of the colonial armed forces, grabbing their weapons, sits atop of this. The Nupi Lal (also Nupee Lal) is the name given to the Second Women's War of 1939 (the First Women's War was an uprising against forced labour in 1904), an uprising against a rice shortage manufactured by British export and taxations laws, the control of rice milling by Marwaris (merchant-class migrants from other parts of India), and a poor harvest after excessive rains. With the price of rice rising and supply diminishing, groups of women from the women's market began blocking the export vehicles taking rice out of the city in early December. The situation escalated as thousands of women protested against the shortage and the heavy-handed response. The uprising featured hostage taking, rice mill sabotage, stoning of soldiers, and violence against the protestors. Numerous scholars have argued that the Nupi Lal was a turning point in Manipur's politics as it exposed the impotence of the maharajah, the brutality of the British, and the power of the non-Manipuri mayang traders (Parratt and Parratt, 2001; Yamben, 1976). The Nupi Lal is woven into Manipuri culture in writing, theatre, and in contemporary protests movements.

The memorial symbolises women's agency in resisting colonisation, outsider control of key commodities, and the trope of motherhood. All of these have contemporary manifestations in resistance to Indian colonisation and the AFSPA, the movement to impose the ILP, both of which have involved women's organisations, particularly the Meira Paibis. Furthermore, motherhood remains an integral part of the way women's agency is enacted in Imphal, including as moral authority to oppose conflict, in seeking justice for atrocities and disappearances, to legitimise conflict by equating 
maternity with nationalism and/or ethno-nationalism, and in constructing symbols and memories of conflicts (see McDuie-Ra, 2014a). Thus while the memorial is a powerful symbol of women's agency, it is the agency of Meitei women that is usually evoked.

December 12 each year is Nupi Lal Memorial Day. Various events are held around Imphal and in other parts of the valley. The complex is the starting point for the Nupi Lal Lamjel, a foot race for members of the Meira Paibis from the complex to Singjamei Supermarket Complex approximately 3 kilometres away. The members of the Meira Paibis are married Meitei women, and the racers include women in their 20 all the way through to women in their 8 os. Women run down the highway in their phaneks (sarongs), running shoes, and often with turban tied on their heads. Supporters line the route in the cold winter weather to cheer on the participants. As the participants reach the finish they assemble in the closed shopping complex, taking over the pavement between stores for a series of speeches and readings to mark the day. I attended the event in 2013 and it was interesting to see tribal women, mostly from the Kabui community, and Pangal Muslim women also participating, reflecting the blurring of ethnic boundaries among women in the valley and the diversity of the original Nupi Lal activists. The Lamjel animates the memorial complex. The sight of scores of women running through the streets, passing the Raj Bhawan where the Delhi-appointed Governor lives and passing the Assam Rifles headquarters that sits on the hill opposite the supermarket, recalls resistance from below; a spontaneous uprising now etched into narratives of Manipuri nationalism, separatism, and resilience.

Yet the Nupi Lal Memorial Complex is also part of a ritualised performance of state patronage and attempted co-option of the Nupi Lal into the history of local and national state-making. The Nupi Lal Ningshing Thouram is held on the same day at the complex. This event sees the key figures of the civilian government - those holding high offices of the Manipur state - pay tribute along with important guests - those holding high offices of the Indian state, mostly members of the armed forces. Under heavy security detail, the Chief Minister of Manipur, other ministers, and their spouses lay wreaths at the memorial beneath the statue of the women confronting the soldiers described above. The Chief Minister makes a speech and guests watch a dramatic reconstruction of the Nupi Lal performed entirely by Meira Paibis - women even dress as the soldiers that enacted the crackdown on behalf of the British.

As with many government-sponsored events in Imphal the importance of the guests can be deduced by where they are seated. The most important people up the front, a middle section of officials of lesser note, and then invited members of the public in the rear. This is typical elsewhere but 
in Imphal the grade of chair is also a signifier of status. The front three or four rows are usually velour and synthetic velvet armchairs with soft patterned fabrics; a few rows back are leather and faux leather armchairs and three-seater couches, and then rows of hard plastic chairs for the public. At the Nupi Lal Memorial on December 12 the VIPs are in the armchairs, mostly senior office holders in the various Indian military and paramilitary forces, as well and the Governor (or a representative), and senior ministers in the civilian government. Seniority decreases as the rows stretch back to the plastic chairs. As many of the VIPs and middle-ranking guests don't show up or only attend for a short time - leaving once the Chief Minister has spoken, the drama performance is delivered to empty rows of grey and black paisley and fake tiger skin armchairs with the invited public watching quietly many rows back; a stark contrast to the cheering along the route of the footrace and the speeches by women activists at Singjamei.

The official gathering at the Nupi Lal memorial reflects the tactic of grafting the state, both local and national, into resistance narratives. Resistance to British Imperialism is highlighted, resistance to Indian occupation is downplayed and virtually erased; at least on this day at this moment. The rest of the year the Nupi Lal hovers over the Indo-Myanmar Highway close to one of Imphal's busiest intersections. It is used for other things, even hosting an education recruitment expo (see chapter 7), but for most of the year it remains a powerful symbol of women's agency in protection of the valley population. Yet it is also malleable; able to be cited in anti-British narratives that are not out of step with narratives of a general broader Indian nationalism, and ethno-nationalist narratives that are deployed against Indian occupation, the armed forces, and AFSPA as well as in the movement against migrants (the ILP movement), and in the protection of Manipur's 'territorial integrity' and its attendant interethnic politics.

Malleability matters because it reflects fragmented sovereignty. There is no singular way that past resistance is interpreted. Manipuri nationalism can be hostile to India and conversely can affirm a shared past (albeit brief) of exploitation under British rule. For instance, the Martyr's Memorial (Shahid/Shaeed Minar) in Bir Tikendrajit Park adjacent to the Mapal Kangjeibung polo ground is dedicated to two heroes of Manipuri resistance, Bir Tikendrajit and Thangal General, who were hung on August 13, 1891; celebrated as Patriot's Day in Manipur. The memorial itself features three tall columns with three Kangla-sha (Kangla dragons) on top, sacred symbols of the Kangla Fort (see Singh, 1998: 29). This site, along with the Heecham Yaicham Pat where Tikendrajit was cremated serve as the official sites where the Chief Minister pays tribute on Patriot's Day. Representatives 
of the Indian state also pay tribute, including the Governor and various high-ranking members of the armed forces. These very public memorials fit into a nationalist narrative that recounts Manipuri resoluteness against colonisation and are not antithetical to similar narratives in other parts of India. Yet in the neighbourhoods Patriot's Day is also used to frame separatist nationalism and recount the last days of Manipuri sovereignty.

Memorials to Jananeta Hijam Irabot Singh (1898-1951) are a little more difficult to place. Irabot grew up in British-occupied Manipur and was a committed activist against both British rule and feudalism; he is seen as a pioneering communist revolutionary in Manipur, especially following the Merger with India in 1949 after which he attacked the acquiesce of the Manipuri elite who supported integration (Parratt and Parratt, 1999/2012). He was instrumental in the Communist Party of Manipur and its military wing, the Red Guard; a group seen, perhaps a little too parsimoniously, as a precursor to the left-wing insurgent movements that have operated in Manipur since. Irabot's legacy is both as a radical left activist and as a nationalist who opposed the old order, the Merger with India, and sought to unify the Meitei population living in other parts of the borderland.

Memorials to Irabot are found in expected and unexpected parts of the city. Outside the offices of the Community Party of India (CPI) Manipur, behind a high wall in the dense alleyways of Thangal Bazaar there is a large bust of Irabot mounted on tiles and cement with a plaque detailing his birth and death dates. The statue has garlands of flowers draped over it, which are refreshed every day or so. It is situated at the front of an open area used for receptions and meetings, though when I visited was being used as a car park. This is a to be expected, after all, Irabot represented an indigenous commitment to communism and is thus claimed by various communist parties in Manipur and in their literature.

For instance, he is featured on the front cover of the July 2013 issue of the CPI Marxist-Leninist Manipur publication Anganba Thwanmichak, where he appears alongside Mao, Lenin and Marx above the hammer and sickle. On the right side of the cover are the passport photos of 18 'martyrs' killed by state security forces in 2001 - mostly protestors taking action against the extension of the ceasefire 'without territorial limits', between the NSCN-IM and the Indian Government, seen as threatening the territorial boundaries of Manipur. Also featured in the background is an image of the Kekrupat, the memorial built for the martyrs. Here Irabot and communist resistance to state brutality are connected to Meitei ethno-nationalism and the need to maintain Manipur's present territorial boundaries. Anganba Thwanmichak is not a static memorial marking the landscape but shows the ways in which Irabot's 
legacy is reproduced in everyday life. Indeed Anganba Thwanmichak is sold like any other magazine or journal - of which there are scores in Imphal - and people read it on the bus, in the park, and while waiting in government offices.

There is another bust of Irabot on the Indo-Myanmar Highway at Yaiskul in front of a petrol station; there is an Irabot Park on the northern outskirts of the city, Irabot Bhavan (or house), and an Irabot high school in neighbouring Thoubal. Irabot's birthday, September 30, is celebrated in Imphal, and other parts of the valley, especially in schools and universities. At some of these celebrations students receive portraits of Irabot and these appear in people's homes - hanging on the walls or in glass cabinets with other paraphernalia.

Other statues of Irabot reflect his construction as a nationalist and ignore or downplay his communism, referring instead to his role as a 'social reformer'. In the south of the city on Mayai Lambi Road in Pishumthong stands a statue of Irabot standing upright with a finger raised as if arguing an important point. The statue stands beside the Namul River on a small patch of grass and was dedicated by then Governor of Manipur, Ved Marwah, in 2000. Ved Marwah served as Commissioner of Police and Director General of the National Security Guard among other posts prior to being appointed Governor of Manipur. He is also author of a 1995 book that discusses violence in the Northeast as part of larger pathology of terrorism (see Marwah, 1995). As governor, Marwah had the power to declare the state 'disturbed', and renew this declaration every six months; which he did throughout his tenure. There are few representatives of the Indian state more symbolic of Indian colonisation and state violence in Manipur, yet this statue of Irabot on a main road in Imphal is dedicated by Ved Marwah, a juxtaposition both ironic and bizarre but also instructive of the ways memorials are bound up in contestations over history, territory, and sovereignty. There are other examples that demonstrate the same ambiguities of nationalist and statist versions of the past: the memorial and remembrance events for murdered left-wing intellectual, writer and founder of the United National Liberation Front (UNLF) Aramabam Somorendra (also spelled Samarendra), the memorial to students who marched against rice shortages in 1965 and were killed by members of the Manipur Rifles known as the Hunger Marchers, and the memorial to civilians shot by the armed forces during a volleyball game at Malom on the western outskirts of the city.

\section{Insurgent Memorials}

Integral to challenging Indian nationalist co-option of resistance are memorials to those killed fighting against the state, in the violence of military 
occupation, and in interethnic conflicts. At Cheiraoching in the city's north is a memorial site to members of underground groups killed fighting against India. At the top of a hill, which is a popular place for recreational walking and for New Year celebrations, is a memorial site enclosed by a high fence. At the centre of the site itself is a plaque adorned with a red communist star dedicated to eight members of the (still active) People's Liberation Army (PLA) killed in a gun battle with the armed forces in 1982 at Kodompokpi. Surrounding the plaque are busts of Manipuri's freedom fighters - Paona Brajabashi, Bir Tikendrajit and Thangal General - alongside Irabot; a merging of resistance of Empire with resistance of India and the Manipuri Kingdom. In contrast to Martyr's Day and the tribute paid at Heecham Yaicham Pat to Manipur's martyrs, the memorial at Cheiraoching is locked and attempts to celebrate the memory of the PLA fighters is obstructed, though it is possible to visit through a gap in the fence; which is the only way I have been able to visit the site.

On the anniversary of the 1982 battle (April 13), families of killed PLA members seek access to the site to lay flowers and light candles (Athoubashinggi Ningshing Numit), a ritual banned during the 199os. Since 2001 families have sought permission from the Guwahati High Court to gain safe access to the site on this day. Student organisations and various civil society organisations also pay tribute, including chapters of the Meira Paibis and even school children. Non-family members are routinely denied entry and have to pay tribute at the foot of the hill, though the crowd at the foot of the hill sprawling onto the road is even more visible than the actual memorial site hidden away on the hilltop. In 2014 the High Court granted permission and relatives were admitted to the site, though the armed forces recorded the names of all the mourners allowed up the hill (Sangai Express, 2014a). With very restricted entry the climb up the hill ends up being a fairly isolated ascent by the relatives. Women dressed in white and soft pink and men in all white, the proper clothes for paying tribute in Meitei society, make their way to the gated entrance to the memorial where armoured vehicles are parked with roof hatches opened and guns at the ready lest there is any trouble from a throng of mostly middle-aged women. As with other years, various underground groups send a message of thanks to members of the public for observing the day. Unable to join the Athoubashinggi Ningshing Numit as a non-relative I have relied on descriptions from residents, journalists, and the excellent photo essay of the 2014 ritual by Shanker Khangembam (2014a).

The reluctance of the armed forces to allow access to Cheiraoching reflects the power of the place to evoke the memory of left-wing insurgency in 


\section{Image 3.3 PLA Memorial at Cheiraoching}

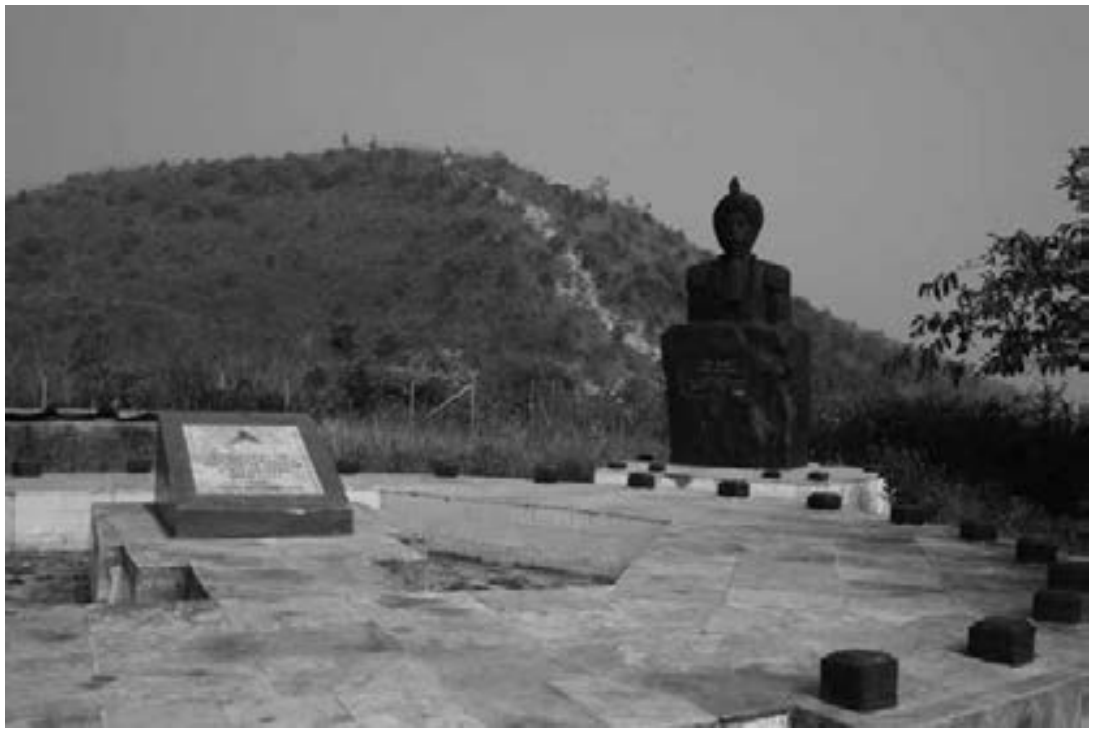

Manipur in an era before the splintering of the polity and the ascendancy of hill-valley politics. Ironically it is an organ of the Indian state, the Guwahati High court, which enables families to pay tribute to secessionist relatives without being arrested or harassed by the armed forces. Each year the families go through the process of seeking High Court permission, itself a bureaucratic ritual to enable the memorial ritual. Clearly the state is able to co-opt the Nupi Lal and Irabot for nationalist narratives. The PLA is a line the state cannot cross in its appropriation of resistance.

Interethnic violence is also memorialised on the landscape. At Kekrupat, a short distance east of Kangla Fort, there is a memorial to the 18 martyrs killed by the armed forces in the 2001 protests against the ceasefire between the Naga NSCN-IM and the Indian Government mentioned above. The site features plaques to the 18 protestors killed alongside a large pukhri. The site hosts a public memorial ceremony on June 18 each year, referred to as 'Great June Uprising Day'. This is a powerful occasion. Members of the public bring floral tributes to the memorial, and there are no restrictions or suspicions as with Cheiraoching. A marquee sits on the grass below the memorial. White-covered seats in neat rows fill the space. Those gathered pay silent homage followed by rounds of speeches and music, recalling not only the brutality of the state but the divisive hill-valley politics that sparked the protest in the first place. Perhaps cognisant of the almost exclusively 
Meitei nature of the event, in recent years the name has been changed to 'Great June Uprising Day and Unity Day'. Relatives also gather here during Tarpan Katpa, a Meitei ceremony of paying homage to deceased relatives giving the site an even richer spiritual significance.

Kekrupat is a distinctly Meitei place surrounded by Imphal's diversity. For the rest of the year Kekrupat sits opposite the Imphal River from one the largest Muslim settlements in the city, across the Imphal-Jessami road from a cluster of several tribal neighbourhoods such as Zomi Villa and Ragailong, and from a notorious strip of grubby hotels used for prostitution. The memorial to innocent protestors killed by the armed forces is a testimony of state brutality and the repercussions for political protest in a disturbed city. Yet the site is also a powerful invocation of ethnic divisions. It has elevated the original 2001 protests to the status of martyrdom in the struggle to maintain Manipur's territorial integrity in the face of alleged attempts by hill communities to redraw the state's boundaries. Meitei martyrdom now has a permanent place on the urban landscape. As many tribal residents of Imphal point out, they have no equivalent in the city and must exercise care in marking territory in any similar way.

Residents also construct temporary memorials to family members killed by the armed forces in neighbourhoods made from stones, cement, or clay. Patrolling members of the armed forces dismantle these memorials and sometimes residents return at night and rebuild them. In other places they make the memorials from hardier materials. For instance, in Takhellambam Leikai (or thereabouts) there is a small row of cement mounds memorialising local youths who have been killed by the armed forces. At one point these were larger, almost like gravestones. The top half was broken off by the armed forces and locals have returned on occasion to rebuild. I visited this site a number of times. It is quite public; the narrow laneways and dense housing suddenly give way to a small market, two pukhris, a cremation ground, a small field where children play, and the memorials stand exposed in this open space reflecting the ongoing battle between residents and the armed forces to remember the dead, to mark and erase state brutality from urban space.

By far the most well known living memorial is Irom Sharmila. Irom has been on a hunger strike protesting against the AFSPA since 2000 after the Assam Rifles opened fire on a volleyball game at Malom just outside the city. Numerous writers have analysed her story in depth, focusing on the symbolism of her Gandhian struggle (Mehrotra, 2009; Vajpeyi, 2009), the politics fought over her body (Gaikwad, 2009), and the ways her fast exposes the brutality of the Indian state (Banerjee, 2004; Chakravarti, 
2012; Sharma, 2014). Sharmila herself has written poetry and prose that is published and translated into English (Sharmila, 2014). Sharmila is a courageous yet complex figure, and much of the complexity is glossed over in accounts of her fast from afar (see Jilangamba, 2009). In the city she is physically present, though inaccessible to most residents, marking the landscape as a living memorial to those killed and disappeared under the AFSPA. Sharmila spends most of her time under arrest in the Jawaharlal Nehru Institute of Medical Sciences (JNIMS). Along Lamlong Road, which runs along the wall of the JNIMS campus, there is a permanent shelter where Sharmila's supporters gather to carry out relay hunger strikes, hold meetings, and greet her when she is released from 'house arrest' in the hospital and re-arrested every six months. It is also where well wishers, activists, and journalists seeking contact with Sharmila congregate. While seldom seen around JNIMS, Irom haunts the landscape of the hospital. Everyone knows she is there but the public cannot pass near her wing. Those that try risk arrest. And the visible presence of the security forces is a reminder about who controls space and determines access to Sharmila.

\section{Conclusion}

Place-making from below through memorials like Cheiraoching and lopped cement slabs in Takhellambam make claims to space by compelling resistance, secession, and the resultant state brutality to be remembered; even if actually paying tribute at them is an ongoing struggle in itself. In contrast, there is a nascent industry in memorialising dead foreign soldiers killed in and around Imphal during the Second World War. In 2014 Imphal's small tourist industry was gearing up for the $70^{\text {th }}$ anniversary of the Battle of Imphal. In 2013 a vote among guests at a function at the British War Museum declared the Battle of Imphal and the Battle of Kohima in neighbouring Nagaland as the 'Greatest British Battle' (Copping, 2013). This proved to be a fillip for the local war tourism industry. The Manipur Tourism Forum and the Manipur Government have seized the opportunity and the higher end hotels in town were adorned with 'Greatest British Battle' banners when I visited the city in May 2014. New tour operators started up, hoping to benefit from the anticipated boom in tourists to the city and to the battlefields. All battlefield tours include a stop at the war cemeteries of Imphal. The most visited is located right in the centre of town just off the main highway running from Kangla Fort north to Mao Gate and Nagaland, accessed by a narrow street past the Kuki Baptist Convention and into a 
cluster of tribal neighbourhoods. The cemetery features a cenotaph where visiting dignitaries, politicians, and members of the armed forces (Indian and Manipuri) lay wreaths on memorial days. On the grass are rows of memorial plaques arranged by regiment. The names span the subjects of Empire - Australian, Burmese, and English. The site is immaculate and maintained by the Commonwealth War Graves Commission.

Children from nearby neighbourhoods play on the grass outside the gate, an unusually large public space in this part of the city. I have seen local youths using the site for intravenous drug use, especially under the tress on the periphery where they escape the view of the caretaker after climbing the fence. This is also one of the very few places I have encountered other foreigners during my time in Imphal. With few conventional tourist sites, foreigners often find themselves here as a way of passing the day. The municipality has caught on. When I first went to Imphal in early 2011 there was a faded blue and white wooden sign at knee height pointing to the access road. Two years later there was a large green and white metal sign at the access road and at other points of the city showing the way to the cemetery. There is another cemetery just behind the Mosque in Hatta, a Pangal Muslim neighbourhood on the other side of the Imphal River and a Japanese war memorial at Nambol just outside the city to the south.

Aside from their abrupt juxtaposition to the rest of Imphal's urban landscape - even accounting for the radical diversity of the built environment in the city - and occasional deviant use of the spaces themselves, the war cemeteries demonstrate the legitimacy, and potential profitability, of the violence of the Second World War in a city where almost every neighbourhood has seen violence in the decades since. The former is an historical and legitimate conflict between states, empires, and ideologies comfortably in the past. Further, the designation of the Battle of Imphal as the Greatest British Battle gives the city a pivotal place in global history and decolonisation in Asia; a process that ended up dismantling Manipur's independence. War tourism reflects attempts by the civilian government to control urban space and show that they can keep the city safe, provide necessary infrastructure, and be a 'destination'.

The memories of a heroic past with global significance help to downplay the messy present. Such ambivalence also demonstrates the ways memory is co-opted by commercial forces in the city. Well-manicured memorials to the (mostly) foreign dead are neutral; they are not of this place, otherworldly and unable to be co-opted by state, quasi-state and non-state actors. Further, they face little risk of demolition by the armed forces. No one will be barred from paying tribute. And they are unlikely to exacerbate interethnic or 
secessionist tensions. Thus in Imphal you are able to visit the grave of a foreigner who fought the Japanese for the survival of Empire, but memorials to those who have fought against the Indian state are harder to find, harder to access, and harder for their families to maintain. And that is just for those whose bodies have been found. For the scores of men, women, and children who disappear each year in Manipur there are few memorials in a city where spatial control is fragmented among state, non-state, and quasi-state actors; control that overlaps, dissolves, and is enforced through surveillance and violence in different sites and different times. 



\section{Exclusion}

In March 2014, Dinesh Tongbram's feature film $23^{\text {rd }}$ Century premiered at the Manipur Film Development Corporation and the Bheigyachandra Open Air Theatre in the Palace Compound. These two venues are a short distance apart next to the Hapta Kangjeibung; an historic polo ground still used for polo but also for staging political rallies, the Sangai Festival each December, and various trade fairs. South of the polo ground is the Royal Palace, where the British moved their installed ruler, Chura Chand, after occupying Kangla Fort in 1891, and adjacent to this the Shree Govindajee Temple built in 1846. To the north along the same road is the City Convention Centre, an oversized building for its surroundings, sitting lonely behind a locked gate covered in reflective blue glass and home to a seemingly abandoned government water tanker. The contrast is compelling: the remnants of the independent kingdom at one end of the road and the new spaces of power, modernity and development at the other. The content of $23^{\text {rd }}$ Century weaves the fading past with a warning about the future. Based on a 1992 play, the film depicts the Imphal of the future as overdeveloped and overpopulated. The extension of the railway into Manipur has led to massive influx of migrants, and Manipuris (though the film mostly focuses on Meiteis) have become a minority in the city. The Chief Minister is a non-Manipuri and the rights of Manipuris have been dismantled. Driven to poverty, humiliating forms of livelihood, and subject to violence by the occupying armed forces, the couple at the centre of the film struggle to survive. The film narrates a common insecurity throughout the borderland, namely numerically small populations distinct from the majority 'Indian' culture and society being overwhelmed by migration into their homelands. The insecurity is not unwarranted given the massive demographic shifts that have taken place throughout the borderland, but particularly in states where protection for indigenous communities is weak as in Assam, Tripura, and indeed Manipur. Yet what makes the Imphal depicted in $23^{\text {rd }}$ Century even more telling for the themes of this book is that connectivity is the cause of the influx. The railway brings the masses of migrants. It is a death knell. It is the end of isolation. The image of a fictitious Imphal train station adorns the poster and billboards advertising the film. This is the future that connectivity invites, unless something is done about it now. The release of the film comes during a popular movement to implement the Inner Line Permit System in the state (ILP). The ILP is a system of controlled entry, settlement, and monitoring of non-indigenous migrants into borderland polities based on 
Image 4.1 Advertisement for $23^{r d}$ Century, Salam Leikai

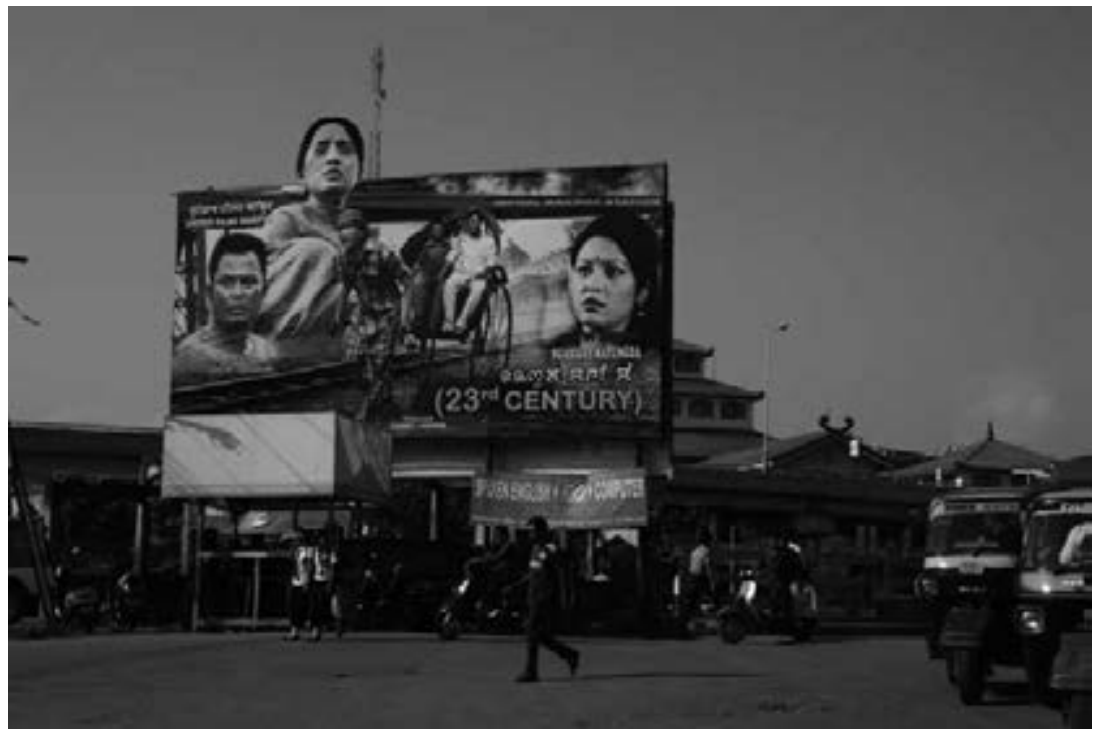

a colonial regulation and currently in force in neighbouring Mizoram and Nagaland. The music video for the lead song from $23^{\text {rd }}$ Century even features clips of the protests calling for the ILP equating the story in the film with the contemporary movement to exclude non-Manipuris from the state. The film also comes at a time of public debate over the merits of the proposed extension of the North East Frontier Railway to Imphal through Jiribam, on the border between Manipur and Assam, due for completion in 2016. Land seizures, displacement, and environmental damage brought by the construction of bridges and tunnels has sparked sporadic opposition, however, the implications of easier entry to Manipur and easier access to Imphal, especially though train travel which in India is still the primary mode of transport for the poor and middle class, strikes at the core of anxieties over territory, belonging, and identity. These anxieties are captured in the film but they also play out in contemporary Imphal where exclusion provides the counterpoint to belonging in a city controlled by state, quasi-state, and non-state actors.

This chapter focuses on exclusion from different spaces in the city. Exclusion produces belonging, and belonging enables place, and place is a way of countering the diffuse hegemony of state, non-state, and quasi-state actors. Places are more resilient by excluding 'others' - realised along various fissures, from different patches of the city. Contesting the presence of the 
armed forces and the dysfunction of the civilian government does not come from a unified collective of individuals and associations. It is tempting to read resistance to spatial control by the armed forces and civilian government as evidence of a unified groundswell of grassroots activism intend on wresting back control of the city streets. Challenges to hegemonic power in the city are certainly bold, brave, and often remarkable given the constraints on agency in the disturbed city. Yet rarely are they inclusive. The dynamics of belonging and exclusion, control and contestation, operate among residents, too. Any notion of a unified counter-hegemony is fragmented during periods of intense interethnic tensions, as during the blockades of the city in 2010 and 2011, when exclusion and belonging are negotiated through struggles among the population with the armed forces and civilian government as bystanders and occasional interveners. However, a much larger movement to exclude non-Manipuris from the city, and the state, in 2012-14, subsumed interethnic tensions. The movement for instating the ILP casts all Manipuris as indigenous peoples united in their precarious geographic and demographic circumstances at the edge of the Indian state and Imphal is the arena where this plays out. These two fissures, interethnic and Manipuri/non-Manipuri, make up the two sections of this chapter. Any discussion of ethnic politics in Imphal is sensitive and this chapter does not attempt to be a comprehensive account of the events of recent years, their causes, or the relative worth of the justifications for the events that unfolded. The focus here is how these events affect everyday life in the city, affirming and jeopardising belonging.

\section{Ethnic Politics}

Conflicts between different ethnic groups in Manipur have played out in Imphal, though they go through phases of heightened and reduced tensions. During my research in Imphal the spectre of two arduous blockades lingered, affecting relations between communities and making blockades a viable tactic in bargaining with the local and Indian state. The threat of a blockade has become a perpetual possibility during any breakdown in interethnic relations. Imphal's geography of vulnerability - a valley surrounded by hills - and the prominence of a discourse that casts Imphal as a Meitei city and the seat of power for a government that supports Meitei interests, not to mention the unexpected success of the two blockades in 2010 and 2011, have all contributed to the appeal of blockades as a form of action in the vacillations of interethnic politics. However, in a plural city 
where members of all of these communities live, the blockades and the interethnic grievances they represent, were experienced in Imphal's 'tight spaces' to recall Bollens' phrase from chapter 2 (2012: 13). Before discussing the ways blockades were experienced in the city I will outline briefly the two longest lasting blockades: Mao Gate in 2010 and the Sadar Hills in 2011.

\section{Mao Gate}

Mao Gate is the entry point to Manipur on the highway from Nagaland located in the Senapati District. Parts of this district are claimed for Nagalim - the Naga homeland that encompasses the present state of Nagaland and tracts of territory in other parts of the borderland including northern Manipur. Senapati and neighbouring Ukhrul District are the frontline of competing subnational territorial claims by Nagas to realise Nagalim and by Meiteis to keep Manipur's present boundaries intact (usually referred to as 'Territorial Integrity' in Manipur).

In May 2010 Thuingaleng Muivah, the Ato Kilosner (leader) of the NSCN-IM, the main Naga independence organisation, conducted a peace and reconciliation tour of all the Naga districts on the Indian side of the India-Myanmar border in preparation for peace talks with the Indian Government. Political and insurgent factionalism, tribal and clan affiliations, interfaith divisions, and the legacy of insurgency campaigns, arrests, and human rights violations by all sides in the Naga struggle necessitated a push for unity during pivotal peace talks. Muivah was received by the different Naga clans and tribes and spoke about unity and peace on each stop. Throughout Naga areas hohos ('traditional' Naga institutions), local governments, and local NSCN-IM chapters organised receptions for Muivah in villages, churches, and schools. Children lined the roads into towns and villages and waved the Nagalim flag to welcome Muivah to their locality.

The Meitei community and the Manipur Government viewed Muivah's tour with suspicion. The tour came at a particularly sensitive time in ethnic relations in Manipur. For many years Naga civil society groups in Manipur have pushed for an autonomous district council in the Naga areas. Such councils exist in other hill areas of the borderland legislated by the Sixth Schedule of the Indian Constitution in 1947. Autonomous district councils in Manipur have fallen under a more opaque regime. Six councils were created in 1971 and subject to direct elections (Gonmei, 2013; Hazarika, 2004; Riamei, 2013). After violence escalated in Manipur during the 1980s, the councils were suspended under the orders of the Delhi-appointed Governor of Manipur. Under pressure from civil society groups a new act was passed 
in 2000, the Manipur (Hill Areas) Autonomous District Council Act. This helped to ease one of the major grievances of the hill population, but the act was never bought into force and in 2006 was replaced with the maligned 1971 act. In 2008 the act was amended once again and these amendments were seen as further stripping autonomy from the hill areas.

The Manipur Government announced elections to the hill councils in late 2009. In April 2010 a number of Naga civil society groups led by the All Naga Students Association of Manipur and the umbrella United Naga Council called for a boycott of these elections (Samom, 2010:33). The Manipur Government was undeterred and scheduled the elections for late May. In response the boycott became a blockade of the two main highways into Manipur, National Highways 39 and 53. This cut off Imphal from the rest of India.

Muivah attempted to bring the peace and reconciliation tour to the same districts and also visit his home village of Somdal in Ukhrul District. The Manipur Government announced they would block Muivah from entering the state. Crisis meetings were held between members of the Manipur Government, the Government of Nagaland, and the peace negotiators from the Indian Government. Meanwhile Muivah waited on the Nagaland side of the border between the two federal states while these deliberations took place.

A number of crucial events took place in the first days of May 2010. Meitei organisations in Imphal protested against Muivah's visit, including the Meira Paibis, the Meitei women's association discussed earlier. Protestors in Imphal supported the decision of Chief Minister of Manipur, Ibobi Singh, to stop Muivah. They also blamed Naga groups for the blockade of the valley and the ensuing hardships. The blockade by Naga civil society organisations and members of the hill communities had now been in place for 25 days.

Communities from all over the hills converged on Mao Gate to welcome Muivah, stationed just a few kilometres away, and protest against the Manipur Government. Those supporting Muivah attempted to stop security forces from reaching the gate. On May 6 an enormous gathering of Naga women organised by the Naga Mothers' Association and the Naga Women's Union staged a sit-in protest on both sides of the border. As tensions escalated Manipur state police tried to stop the demonstrators from reaching the border post and fired tear gas and bullets. Footage of the shootings shows crowds of protestors running to the side of the road to find shelter. Over 70 people were injured. The crisis escalated when the police shot and killed two Naga teenagers, Neli Chakho and Dikho Loshou. Video of the shooting quickly circulated through the Internet and for a time was posted on YouTube, though it was removed by mid-2011. Naga protestors reinforced road blockades with trees, tyres, stones, and trenches. The Indian Army, 
also present at Mao Gate, vowed to clear the road, but as one journalist caught in the blockade reported they 'had no idea how to deal with this army of women' (Bhattacharjee, 2010: 36). The uncertainty that followed meant many protestors who had come to Mao Gate could not return home and as many as 4000 persons were estimated to be displaced in the weeks that followed (Kikon, 2010: 41).

After the shootings the blockade of Imphal held for six more weeks. In the meantime the controversial elections went ahead. In some Naga constituencies bandhs ensured very low voter turnout and in several constituencies incumbents had no opponents. Meitei civil society actors held further protests in Imphal, demanding the Manipur Government take action to end the blockade. After the blockade was finally lifted the situation for Nagas and Meiteis altered little. As a local journalist, Anjulika Samom notes, 'the blockade and Muivah's proposed visit have left a deep mark on the psyche of the people as well as the political equations of this tiny state' (2010: 33). Mao Gate shows the incompatibility of the imaginations of neighbouring communities as seen through what Jilangamba calls the 'simplistic, homogenous and unilinear view of the past' (2010b: 39). Jilangamba sees this view as offering 'threatening and one-dimensional choices (that) not only encourage ethnic tensions, but also limit political expression only to ethnic-based articulations' (2010b: 39).

\section{Sadar Hills}

Less than a year later the Sadar Hills Districthood Demand Committee (SHDDC) called for a weeklong blockade of two highways connecting Imphal to India in one direction and to the border with Myanmar in the other. The SHDDC demanded the upgrade of the Sadar Hills district to a revenue district - giving the majority Kuki community in this area a higher level of territorial autonomy. Nehginpao Kipgen notes that the Sadar Hills demand has been made since 1972, and the Manipur Government made promises in 1997 and 2000 to change the status of the district (2013: 31). Haokip cites the Kuki Chiefs' Zonal Council meeting in September 1970 as the origin of the demand (2015: 95), based in part on the colonial delimitation of the Sadar subdivision in 1933 with headquarters based at Kangpokpi (Oinam, 2003: 2037). The SHDDC dates from 1974. Counter-claims of indigenous status by Naga communities when compared to 'migrant' Kukis, usually based on colonial gazetteers, have made the creation of a district a controversial decision and one the Manipur Government has delayed lest it aggravate interethnic relations (Shimray, 2001). 
In June 2011, a new leadership was elected to the SHDDC and they demanded the fulfilment of past promises by the end of July the same year (Haokip, 2012: 96). The blockade began in July 2011 with the support of local chiefs from Kuki villages and various civil society organisations. Things got out of hand when protestors torched vehicles that had violated the blockade and when a truck lost control and killed three women after being pelted with missiles by the SHDDC volunteers (Hueiyen News Service, 2011a). Local government offices were burned in locations along Highway 39 a few days later (Hueiyen News Service, 2011b). In response the Manipur Government implemented Criminal Procedure Code Section 144 (CrPC 144) - a law used across India to prevent the assembly of more than five people.

As the blockade began to receive more attention, Naga organisations, such as the All Naga Students Association Manipur, the United Naga Council and the Tangkhul Katamnao Saklong argued that any agreement about the status of the Sadar Hills requires the consent of the Naga population living in the area. In mid-August the Naga People's Association held an emergency meeting of Naga associations, chiefs, and public leaders to safeguard Naga territory and to condemn 'any hidden agendas and communal designs' (Hueiyen News Service, 2011d). The response from various Naga associations evoked the Naga-Kuki tensions of the 1990s and the misalignment between territorial claims of one ethnic group and the plural population in this part of the state. Kuki organisations, such as the Kuki People's Forum, criticised the involvement of Naga organisations in what they saw as an issue between Kukis and the government (Hueiyen News Service, 2011f)

At the same time the Manipur Government was under pressure from drivers' associations and traders to provide safe passage for their vehicles. After the death of a truck driver on August 13 the All Manipur Road Transport and Motor Worker's Union called a strike. Nothing in Manipur moved and the impact of the blockade intensified. Through the rest of August 2011 and into September the SHDDC escalated their protests, holding sit-ins and mass prayers on Indian Independence Day (conventionally a day of protests and strikes throughout Manipur), while a group of 40 women wearing black went on a hunger strike in the Sadar Hills (at Kangpokpi, Saparmeina, and Motbong) (Hueiyen News Service, 2011e). The involvement of school children in protests drew particular attention, leading to the charge in the Imphal press that they are being used as 'human shields' (Sangai Express, 2011a). Talks between the SHDDC and the Manipur Government stopped and started. When these faltered the SHDDC appealed to the Prime Minister of India, the President, and also staged protests in Delhi itself - national recognition being a common tactic for many of the communities in the 
borderland to legitimise territorial claims and gain leverage with their respective state governments.

In an unusual move the SHDDC also sought the patronage of the titular king of Manipur, Leishemba Sanajaoba, in a ceremony at the palace in Imphal (Sangai Express, 2011b). The photographs of the event show several prominent Kuki senior citizens, one of whom I was fortunate enough to interview two months later, and members of various Kuki associations presenting gifts to the king, himself a very marginal figure in contemporary Manipur (Raj, 2011). The idea that members of one of the tribal hill communities would seek the approval from the last remnant of the Meitei royal family to increase their autonomy appears to contradict the dynamics of hill-valley politics. However, the move was pragmatic; after almost three months of the blockade the SHDDC needed all the support it could get, especially in Imphal that was wilting under the shortages and inflated prices, and also strategic in that any alliances between Meitei and Kuki, even with a powerless figurehead of a defunct kingdom, would isolate Naga opposition to the movement.

Protests and counter-protests continued in the Sadar Hills, and to a lesser extent in Imphal itself, and Naga groups staged a counter-blockade and a 'silent rally' in Imphal. Vendors mobilised against the blockade highlighting their economic hardship, including shutting down one of Imphal's main markets. One vendor's association (Manipur Keithel Nupi Marup Ibeni) pressed the government to make the highways 'blockade proof for all times' (Hueiyen News Service, 2011g). In early October the Minister for Consumer Affairs and Public Distribution inspected food stocks and claimed the city had only 10 days of food remaining, but that people should not panic - a statement that unsurprisingly triggered widespread panic (Hueiyen Lanpao, 2011c). A memorandum of understanding between the SHDDC and the Manipur Government was signed on 31 October ending the three-month blockade, though it was still some days before vehicles began to move freely along the road. After the blockade was lifted the press featured daily announcements at the numbers of empty trucks leaving Imphal to and the numbers arriving to restock the city with food and fuel. The memorandum agreed to grant district status as 'early as possible'. Three years later Kuki groups were once again protesting the failure for the district to be granted.

\section{Belonging and the Blockades}

Mao Gate brought hill-valley politics back to the centre stage of Manipur's politics. The territorial claims of the Nagalim movement and the territorial 
integrity of Manipur's existing boundaries cast Naga on one side, Meitei on the other. It brought back the memories of the protests in 2001 and the 18 Martyrs killed on the same issue, a tragedy memorialised in Imphal and in the observation of State Integrity and Unity Day as discussed in the previous chapter. The Sadar Hills evoked the similar fissures between hill and valley, yet more importantly it reawakened the tensions, hostilities, and memories of the Naga-Kuki violence of the 1990s, violence that led many families to flee the hills and settle in Imphal. The 'success' of the blockades in terms of their longevity, though not necessarily their outcome, gave hill communities a powerful tool at their disposal. The blockades also exposed the fragility of connectivity. With more and more food, goods, and materials coming from east across the international border and west from India the blockades demonstrated the vulnerability and insecurity of Imphal.

The blockades drove up the cost of goods, especially food and fuel. In particular non-Manipuri traders, many of whom are members of the Marwari trading community active throughout India, were subject to accusations of hoarding and profiteering. During the blockades the indigenous population, whether tribal or non-tribal, felt particularly insecure at the notion that outsiders controlled a large portion of their food supply - even when the traders in question were born and raised in Imphal. This insecurity lingered through to the zenith of the ILP movement in 2013-14 when violence targeted at this community escalated.

The blockades affected all traders. Without goods arriving in the city from India there was less to sell. Small-scale traders could not travel back and forth to the border with Myanmar and the vendors who buy and re-sell these goods in Imphal also faced depleted stock. With many residents unable to work they spent less on non-essential items, and even these items became hard to obtain as the blockades wore on. The Consumer Development and Public Distribution Department ended up organising mobile markets that went around to different neighbourhoods with essential commodities sold out of the back of trucks under state police guard. They also tried to fix prices for commodities, though policing this proved difficult. Student unions took up the task of policing vendors and acting on overcharging in response to perceived government ineptitude or unwillingness.

As fuel shortages became more severe and as protesting transport workers went on strike, school buses and other urban transportation stopped running. Students stopped going to school, many of which closed. Some of the private schools in the western and southern parts of the city discussed at length in chapter 6 remained open during the period as the students stayed in hostels on campus or nearby. In fact, remaining open during blockades 
is a selling point for some of these schools, as discussed in chapter 7. People with jobs stopped going to work or went infrequently - especially if they had to commute for some distance. Workers in the informal economy missed out on day labour. Those who could went back to their villages. Hospitals ran low on drugs, and for a time in 2011 the two main public hospitals suspended surgical operations owing to lack of oxygen - a circumstance that furthered a lack of faith in the public system (Hueiyen Lanpao, 2011). Those with the means found ways around the blockade. Air traffic was unimpeded and businesses with spare capital could fly supplies in. The black market thrived. Connections could secure things like construction materials, gas cylinders, and fuel.

Personal safety was even more precarious than usual during the blockades. It was not just the armed forces and underground groups that posed a threat; residents of communities seen as responsible for the blockades became targets of harassment by other residents. For instance, members of targeted communities reported that they were sometimes refused goods by vendors and shopkeepers from other ethnic groups. In response, residents tried to buy goods from members of their own ethnic group where possible, concentrating their movements in their neighbourhood. Networks of underground groups, politicians, civil servants and traders were necessary to ensure the flow of food and fuel into neighbourhoods. The plural city suddenly became very tightly bound and the ethnic composition of each patch of the urban landscape became the defining feature of each space.

In conversations during fieldwork the blockades would often come up when discussing neighbourhoods, work, the black market, the cost of living, safety and interethnic relations. The hardships of everyday life experienced during those periods are unlikely to be forgotten quickly, especially given that the city was blocked for almost 6 months in an 18-month period. The fabric of interethnic relations was damaged. However, the rhythms of everyday life resumed and communities also resumed their interactions with one another: in the workplace, at festivals, in the market, as friends and in mixed families.

I learned about life in the blockades from Flora. Flora lives in Nagaram, a Tangkhul Naga neighbourhood very close to the centre of the city. The highway to Ukhrul passes the entry to Nagaram: fitting, as Ukhrul is the Tangkhul heartland. The stretch of businesses on the highway feature shops run by Tangkhuls and a strip of fruit and vegetable vendors crouched under umbrellas selling meat, fruit, and fish. Nagaram was founded in 1961 as a Tangkhul 'village' close to Imphal. A large foundation stone sits on the 
periphery of the neighbourhood facing the main road and in 2011 a new monolith was unveiled celebrating the golden jubilee (50 years) of settlement. Foundation stones are a vital part of place-making and for tribal communities they are necessary symbols for making claims of longevity and legitimacy over a patch of Imphal. As development projects are accelerated, evictions enacted and contested, and compensation negotiated, foundation stones and settlement dates are important tools for engaging the state. This is even more crucial for communities with no other evidence of rights to the land apart from a history of occupation.

The southern border of the neighbourhood meets the highway and the houses here are well established, usually made from cement, with outer walls, drainage and cars parked in front. The northern and western ends of the neighbourhood spill out into fields and wetlands. Despite being hemmed by urban settlement on all sides, the back of Nagaram is a patchwork of agricultural land, wasteland, and construction. The land here was bought by a Tangkhul politician from a few Meitei families eager to sell and move out of the flood plain. Looking at the neighbourhood using satellite imagery, the unexpected patches of green stand out among the density of settlement. The green is rapidly being 'filled in' with modest dwellings made from bricks, corrugated iron sheets, and bamboo thatch, as well as different combinations of all these materials. Nagaram is growing as more Tangkhuls move to the city from the hill areas or settle in the city after living outside the state.

Nagaram certainly has the feel of a village. Election posters for local Tangkhuls running for office, advertisements for healing missions from visiting theologians from Korea, and announcements for community events in Ukhrul are pasted onto the outer walls facing the main laneways. There is a bilingual Tangkhul/English daily newspaper distributed in Nagaram and elsewhere in Imphal. And there are few non-Tangkhuls in the neighbourhood, especially in the evenings and after dark.

Flora lives in Nagaram with her mother and other relatives are often staying in the house while they conduct affairs in Imphal. Like many people in Nagaram, Flora also has a family home in the hills and she returns there often, especially now the road is in better condition and the route relatively safe from ambushes by underground groups and harassment by the armed forces (though there are a number of checkpoints). Her house has a garden and small pond within the outer walls and a completed ground story along with a half-completed upper floor. She keeps her pet dog within the compound and once remarked to me that dogs go missing in tribal neighbourhoods, hinting that it might be caught and eaten. 
Flora loves the neighbourhood. She is passionate when she speaks about it and the ways in which Tangkhuls have made a home in the city. She brings me around the neighbourhood every time we meet, showing me new houses and telling me stories about the residents of existing ones: the house of a politician alongside the house of a well known underground figure, the houses with drinking dens in the back, the house of a retired local sporting star. Everyone in the neighbourhood knows her, too; we always stop to chat to children she has tutored, friends from church, a well-known Tangkhul singer and aspiring politician. Nagaram has a very strong sense of place; a sense of place based on belonging and exclusion.

During the Mao Gate blockade Flora's life was very difficult. She worked on the other side of the main market, a distance of only 5 kilometres, in the offices of a not-for-profit. Despite the distance she had to pass through neighbourhoods of several different communities, and with Nagas, and Tangkhuls in particular (Muivah is a Tangkhul), being blamed for the blockade, the journey became riskier as the blockade wore on. As fuel became scarce and more expensive it was harder to get any transport in the city, so she had to walk through Imphal's ethnic patchwork. At other times this was not an issue, but during the blockade and as a member of a community singled out in the counter-protests, this could be a hazardous journey. There were also soldiers and police everywhere, also a deterrent. Like many other people across the city she stopped going to work.

The neighbourhood turned inward. Fewer people ventured out. Residents from other ethnic groups did not want to venture in. Flora related the story of going to the main market to try to get food and not being able to find any rickshaw puller willing to take her back to Nagaram or anywhere near it. In the final month of the blockade Flora stopped going to the market as vendors from different communities refused to sell to her. Invisible lines separating patches of the city were drawn along roads, gates, and boundary walls. Social relations replicated these divisions.

Goods did come to the neighbourhood through networks activated by local politicians and by underground groups as well as the periodic mobile markets organised by the government. Nagaram was in a more fortunate geographic position than some neighbourhoods as it was on a highway out of the city. Thus, vehicles that managed to get through, whether through pre-arranged connections or by paying bribes to the collection of organised and ad hoc people blocking the highway, were unloaded here before meeting the counter-protestors closer to the city centre.

With many people staying home from work they were not getting paid. The goods being sold (cooking fuel, firewood, food) were at high prices and 
hard to afford. In this environment a significant number of residents left Nagaram to return to villages in the hills. Flora too decided to return to her village for a few weeks, afraid that as the neighbourhood emptied out it could be more vulnerable to violence from other residents or raids by the armed forces. Leaving the valley was a frightening journey. Communities in the hills were blocking traffic from entering the city; communities in the valley were doing the same in the other direction. In Flora's case her vehicle passed though with only minor incidents (a few rocks thrown), especially when compared to some other stories of vehicles being stopped and the passengers being removed.

Flora returned soon after the blockade was lifted. However, it took her a long time to move about the city in the same way as she had done prior to the blockades. When I saw her almost a year later she was still very cautious about spending long periods in non-tribal areas. Yet she admitted this was probably the same for other communities. The city had become a collection of small enclaves. For Flora this evoked a much deeper fear that one day all the non-Meitei residents would be forced to leave Imphal and return to the hills. With the hills unable to reabsorb this population and with many members of the population ill equipped to create livelihoods back home, communities were preparing by purchasing land in the foothills of the valley, and in some cases, outside Manipur.

Interethnic tensions and outright violence have taken place in the past, the Naga-Kuki violence of the 1990 and the 2001 protests against the Naga ceasefire being the most pertinent examples that not only shaped the politics of Manipur but the demographics of Imphal. The blockades of 2010 and 2011 cut off a plural city; plurality that emerged, in part, from the violence of the previous decades. The blockades sought to damage the Manipur state but also the majority Meitei community. Yet members of the ethnic communities behind the blockades also suffered as residents of Imphal. Neighbourhoods were even more important as spaces of belonging, safety, and exclusion. Furthermore there was a discernable undercurrent of instability to interethnic relations in the city. It seemed any random incident could trigger interethnic tensions. And this is what happened in December 2012 during what became known as the 'Momoko' incident.

In December 2012 in Chandel, a town 90 kilometres from Imphal, Meitei actress Momoko Khangembam was assaulted and molested during a concert at a local high school by Livingstone Anal, a member of the NSCN-IM, who also fired shots at other performers who tried to intervene (Sangai Express, 2012b). Livingstone then absconded and security forces began a search operation. Condemnation of the incident was swift and came from actors associations, 
members of parliament, women's organisations, and from the NSCN-IM leadership (Sangai Express, 2012b). The initial reaction suggested a level of solidarity among the main ethnic communities. In an incident that could have triggered the kinds of hill-valley and Naga-Meitei tensions of 2010, the response from across the spectrum of ethnic groups was universal condemnation. However, protests in Imphal in the following days singled out Livingstone and the NSCN-IM. One frequently photographed placard in the Imphal protests on December 20 read: 'We condemn the barbaric act of NSCN-IM'. The incident provided an opportunity to voice grievances with the NSCN-IM, with the deliberations between NSCN-IM and the Indian Government that have consequences for the future boundaries of Manipur, and with their actions in Imphal. Various organisations supported calls for an infinite bandh until Livingstone was brought to justice. The bandh brought life in Imphal to a standstill once again. Teargas was used on the protestors and a journalist, Nanao Singh, was killed by police fire. Blockades in the streets of Imphal were set up using debris, garbage, and tree branches to block movement thought the city run by men and women, mostly from the Meitei community.

At the same time hundreds of migrants from Manipur living outside the state returned home for Christmas and were stranded in Imphal, awaiting transport home to the hill areas. If Mao Gate and Sadar Hills showed the vulnerability of the city to blockades started in the hills, the Momoko incident showed the dependency of the hills on transit through the city. Notable tribal organisations including the All Manipur Christian Organisation and the Kuki Inpi Manipur asked that the band $h$ be lifted for Christmas. It wasn't. Some of the hill communities began to accuse the protestors of targeting Christian communities and counter-strikes were called in the hills. The Manipur Government was targeted for failing to produce Livingstone and by some hill communities for failing to quell the interethnic turn in the protests. By mid-February things had died down though Livingstone remained at large.

I was in Imphal for the first few days after the Momoko incident. On the day following the incident the first rumours of blockades on traffic leaving the city were circulating. In the mid-morning I walked to the stretch of highway in front of the Tampha Hotel on the Indo-Myanmar Highway where several of the private long-distance bus companies sell their tickets and collect passengers. There was already some uncertainty about what was going on. Buses lay idle along the highway with no one loading any thing onto the top. Cargo to be transported to the hills was strewn on the pavement. Young men from the hills dressed like Korean soap stars with dyed spiky hair and coloured jeans sat on their luggage tagged with labels from the flight that arrived from Delhi that morning. A group of women with infants waited around with bags 
of Christmas shopping. Small crowds had developed in front of the bus ticket offices and the salesmen shouted instructions into telephones and did their best to answer the questions coming from the stranded passengers. With little else to do, many travellers retreated to the pork and rice hotels across the highway; where I also spent my morning among shrugging shoulders having pessimistic conversations about the fabric of interethnic relations in the city.

During a conversation over purple rice with a group of Imphal residents going to see family in Karong, a town between Imphal and Mao, David, a hotel worker of mixed Naga-Kuki parentage, offered his take on things. David was sporting a black eye. He explained he got into a fistfight the night before. He wasn't really sure what it was about, but at during times of tension 'everyone wants to fight anyone they see'. David gestured to the immobile buses over the road and commented: 'This is how we live in Imphal now. Waiting for blockades to end. While the rich just take a plane'.

Feeling very self-conscious I headed to the airport the following day. There were blockades and protestors at different points on the highway, though they let the small auto-rickshaw I was in pass through. There was very little traffic, though a few private cars were on the road. After arriving home a few days later I telephoned my friend Romi to see how things were. She said I was lucky to have left that morning. The city has once again ground to a halt and tribals heading home for Christmas were being stopped. 'It's like last year', she said, 'everyone is in their own neighbourhoods or with their relatives waiting for it to pass'. And pass it did.

The blockades demonstrate the ways in which the urban landscape becomes an arena for territorial politics to play out. Imphal's plurality is aggravated in these moments but also enables communities to feel belonging and safety in their own enclaves. The feeling of safety comes, in part, from excluding 'others'. Successful place-making in the city appears to hinge upon the degree of exclusion as much as a sense of belonging. For residents in mixed neighbourhoods safety and belonging are more fleeting, but these neighbourhoods can also hold together. The interethnic exclusion of 2010-12 dissipated somewhat in 2013-14 as a larger project of exclusion was reinvigorated; the exclusion of non-Manipuris; the majority of whom dwell in Imphal.

\section{Indigenous Politics}

Migration of non-Manipuris into the state has been a contentious issue for over a century. For the purposes of this section I will use the term nonManipuri to refer to the collective of diverse migrants lumped under the 
local term mayang. Mayang is racialised category referring to 'mainland' South Asians from India, Bangladesh, and Nepal, many of whom have been in Manipur for several generations while others have come to Manipur after periods settled in other parts of the borderland, such as Assam and Meghalaya. For instance, some of the Nepali settlers in and around Imphal left Meghalaya after ethno-nationalist campaigns in the 1970s and 1980s evicted them. Similarly some of the Bangladeshi migrants in Manipur arrived after fleeing violence in Assam. Mayang usually does not refer to tribals from other parts of the borderland that have migrated to Imphal, nor usually to Burmese. Mayang are cast as foreigners, evoking the sovereignty of the former kingdom rather than the contemporary Indian state. To put it another way, mayang are foreign to Manipur even if they are citizens of the nation-state in which Manipur is now a part. Imphal is the epicentre of a broad movement to restrict migration of mayang into the state by introducing (or re-introducing) the ILP. I will use the term non-Manipuri in this chapter as I wish to counterpose it with Manipuri, itself a concept being reconstructed through the ILP movement.

The idea of non-Manipuri as a distinct group also depends upon some recognition of Manipuri - a category that is often used interchangeably with Meitei and thus excluding $40 \%$ of the state's population. In the last decade 'indigenous' has become a common term to assemble the tribal and non-tribal population in a single category and attempt a unified position on restricting migration into the state. One of the most powerful organisations involved in the ILP campaign, the United Committee Manipur, even breaks indigenous down to 'Indigenous Meitei and others' and 'indigenous tribals' to further the sense of shared fate at the hands of the migrant wave.

The history of pre-colonial migration into Manipur involves captives, slaves, imported religious instructors and courtiers, volunteer migrants and inter-marriage into the various Meitei yeks or clans. The colonial era brought traders and labourers from other parts of the Empire in large numbers along with the establishment of a Foreigners Department to regulate and tax migrants, a history that others have covered in detail (Banerjee, 2012; Irene, 2010; Parratt, 1980). The main issue here is that regulation of migration into Manipur is not new and its history is continually evoked in contemporary campaigns for the ILP, though often neglected is consideration of flight from Manipur by non-Manipuris in the decades since the 1980 os (Banerjee, 2012: 105-6).

$195^{\circ}$ is a watershed year as the permit system for foreigners was dismantled following the Merger with India: a deeply symbolic surrendering of sovereignty exemplified by the loss of legal mechanisms to control 
movement in and out of the territory. After the Merger, Manipur came under Article 19(1) of the Indian Constitution providing all citizens freedom of movement and the freedom to settle and reside anywhere within India's borders. However, Clause 5 of the same article provides exceptions where existing laws imposing restrictions is in place and the state can make a law imposing 'reasonable restriction' in the interest of the general public or for the protection of any Scheduled Tribe. As is now clear the population of Manipur includes Scheduled Tribes in the hills but not in the valley.

Manipur experienced rapid population growth in the decade 1951-61, the decade after the permit system was lifted. The Statistical Handbook of Manipur records population growth at $35 \%$ in that period - almost $15 \%$ higher than the national average, followed by $38 \%, 32 \%$, and $29 \%$ in the three decades that followed to 1991 (Manipur Directorate of Economics and Statistics, 2002). Population growth was closer to the national average in 2001 ( $25 \%$ and $22 \%$, respectively) and was much lower in the 2011 census at $18 \%$, matching a drop in the national-level growth in the same period $(17 \%)$ (Census of India, 2013). In sum, following the lifting of permits the population of Manipur grew much faster than the national average. In the last two decades it has dropped and moved closer to the national average.

The movement against outsiders depends upon two linked arguments supported by a range of demographic data on the one hand and prophetic scenarios similar to the future depicted in $23^{\text {rd }}$ Century on the other. The first argument is that the population of non-Manipuris is growing faster than the indigenous population and will soon exceed it. This is due to uncontrolled migration and a higher birth rate among migrants when compared to the indigenous population (UCM, 2005: 29-50). The United Committee Manipur, an organisation at the forefront of the movement for the ILP, argues these factors will 'threaten the very existence of the Manipuri identity' (2005: 64). The second argument is that the quality of life in Manipur is negatively affected by the growth of this population as they dominate business though access to capital, the mid and bottom end of the labour market by working for lower wages than locals and in jobs locals are unable to access or unwilling to do, and by threatening the culture and traditions of a numerically small population/s. The presence of outsiders is exacerbated even more by the economic hardships of life in the disturbed city.

With this in mind it may seem odd that there is such a strong 'pull factor' in the disturbed city. I have often wondered what continues to attract migrants to Imphal, given the dire local economy and the routine violence of everyday life. Yet people continue to arrive, guided by promises of work, stories of returnees who have spent time there, the opportunities 
from border trade, and by the centrally funded infrastructure projects that require labour for building cantonments, border roads, and civilian infrastructure. It is also interesting to consider the flow of migrants into Imphal at the same time as locals leave the city for other parts of India and beyond. During my research with Northeast migrants living in Delhi respondents would often speak of the unequal exchange of intelligent and skilled indigenous people contributing to the economies of metropolitan India, a brain drain of significant proportions, to be replaced by unskilled labour from the same heartlands, members of the armed forces, and central government bureaucrats (McDuie-Ra, 2012a: 85).

The validity of the arguments about the influx of migrants into Imphal is not my concern here; rather, I am interested in the ILP movement as a declaration of who belongs in the city, who decides, and what action is taken to shape the urban landscape along these lines. There have been so-called 'uprisings' against non-Manipuri migrants in 1980 and 1994, spearheaded by the All Manipur Students Union. However, the issue has picked up such momentum in the period from 2011 to 2014 that the most recent activism can be characterised as unprecedented.

The most recent incarnation of the movement began in 2011 when the Chief Minister of Manipur, Ibobi Singh, promised the state assembly that he was willing to implement the ILP system in response to a private member resolution by a member of the Communist Party India, which was then part of the ruling alliance (Samom, 2011). In June 2012 there had been no action and the Federation of Regional Indigenous Society (innocuously abbreviated as FRIENDS) began a series of actions on the first day of the assembly session. In the months that followed, momentum grew and other organisations (including the Manipur Peoples Party, the Meira Paibis, different vendors and workers associations) staged their own actions targeting the Chief Minister of Manipur urging him to introduce the ILP. An umbrella group, the Joint Committee on ILP (JCILPS) was formed in July 2012 and assumed the vanguard.

The politics around introducing the ILP warrant brief attention. The ILP requires non-indigenous people to apply for a permit to enter the state, to work, and to settle. As mentioned above the ILP is in place in other parts of the borderland, including Mizoram and Nagaland, and has been previously in place in Meghalaya. According to the Constitution of India the Union Home Ministry needs to implement the ILP. One of the main reasons the movement has not yet succeeded is that the Home Ministry refuses to veer away from the boundaries set out in the Eastern Bengal Frontier Regulation of 1873. The Act is the colonial law upon which the 'inner-line' was based and 
in contemporary India an ILP can be instated where previously promulgated under the 1873 regulation. Indeed, the then Minister of State and Home Affairs Mullappally Ramachandran cited the 1873 regulation in September 2012 in rejecting the proposal for the ILP in Manipur (Sangai Express, 2012a). The state government can, technically, impose the ILP but as inter-state migration falls under the Union list, any state government would not be able to enforce the law on violators. Resolutions were passed, delayed, and blocked in the state assembly during 2013 while the Indian Government held firm on the 1873 line being the only basis for the ILP. Still, the JCILPS and other groups lobbied the state government to pass a resolution and to meet with the Indian Government on the issue, while also directly lobbying the Indian Government and encouraging Manipuri migrants based in Delhi to do the same.

During fieldwork in Imphal I would come a range of actions calling for the ILP. Banners calling for the ILP could be found hanging from the entrance to the main market with slogans like: 'Implement the Inner Line Permit System in Manipur. Save Indigenous People'. Sit-in protests were held in different neighbourhoods throughout the city. Various groups held rallies and bandhs. And the issue was a constant in sessions of the state assembly and in media coverage of local politics.

At first it was possible to experience these events: to stand in the crowd, to chat with participants, to witness the tense encounters between Manipuris and non-Manipuris, to observe the armed forces cordoning off a street for yet another rally. However, during later periods of fieldwork in 2013 and 2014, it felt impossible to pin down what was going on. The sheer number of actions taking place on the issue was staggering. There were so many organisations involved, so many different forms of protest from hunger strikes to market shut downs to 'black badge' campaigns, and - by 2014 - violence against non-Manipuris that I felt overwhelmed. Even tracking the events through the media and through friends in Imphal proved a challenge as almost every day there was some mention of ILP activities.

JCILPS, student groups, and certain underground groups began blocking the entry of non-Manipuris into the state, setting up checkpoints on the roads, boycotting travel companies that let non-Manipuris enter on their buses, and protesting the proposed railway extension into Manipur at Jiribam - an action synchronic with $23^{\text {rd }}$ Century. They also turned to monitoring non-Manipuris already in city, demanding identification papers, detaining and forcibly evicting anyone who could not vouch for their identity. In August 2014 the JCILPS lunched a 'verification drive' calling on volunteers to assist with checking identity cards and notifying of 
any fakes (Sangai Express, 2014b). Boycotts were called on non-Manipuri businesses, on businesses hiring non-Manipuris, and landlords renting to non-Manipuris. For a period in August and September 2014 a curfew on nonManipuris was in place and enforced by civilians - an extraordinary shift in the spatial control of city streets. Electoral rolls were scrutinised in the lead up to the 2014 national poll and suspect names were identified and tracked down. The name and voter identification of suspect persons was often published in the newspapers. The Deputy Chief Minister, Gaikhangam, suggested that the government would set up 'flying squads' to monitor the influx into the state. Violence was widespread, both in actions against nonManipuris, including an attack on Telugu students at the National Institute of Technology campus in Imphal in September 2014, and by the security forces against protestors. Several key activists from JCILPS were arrested, some on charges of association with underground groups - always an option for the authorities in the disturbed city, and others with no charges (Roy, 2014).

The position of the civilian government at the state level was inconsistent with the Deputy Chief Minister and Chief Minister adopting different positions. While the Deputy Chief Minister supported monitoring nonManipuris, the Chief Minister Ibobi Singh was less forthcoming. Ibobi negotiated with the ILP movement but promised little, trading the release of members for a suspension of monitoring and curfews. At such moments, the Manipur Government was trapped between the expectations of the Indian Government, especially the Home Ministry, to align with their steadfast opposition to the ILP and insistence on the 1873 line - not to mention the consequences of failing to protect Indian citizens targeted in the agitations in Imphal, and the groundswell of local support for the ILP and escalating acts of defiance and violence to force the civilian government into action. The result was a stalemate. The movement for the ILP did not exactly fail. The demographic pressures experienced by ethnic minority communities in borderland polities ensure that it will remain on the political agenda until actors pursuing greater sovereignty for Manipur are comfortable that they can control movement and settlement of non-Manipuris. However, the stalemate shows the inertia of governance that can develop in the disturbed city - in the sensitive space. Overt support for the ILP and the violent agitations for its implementation could cast the Manipur Government as separatist and counter its desire to display loyalty in the face of decades of separatism. To put it another way, as various actors in Manipur have sought secession from India and from Manipur itself, the state government has had to prove it loyalty and obeisance to the laws of India. 
As the tensions escalated, the police stepped in to try to protect nonManipuris. Perhaps the most striking measure was the establishment of a relief camp at Dharamshala - also referred to as Gurdwara Sahib after the Sikh temple that takes up part of the building - in Thangal Bazaar, Imphal's commercial hub. On September 12, 2014, the Imphal West police moved non-Manipuris from different parts of the city into the safety of the 'camp'. The photographs of the inside during this period evoke painful scenes of displacement: scores of young men and boys spread out on mats and sheets on the marble floor, other sit in small groups passing the time, bottles of water and rows of rubber sandals the only other objects in the room.

Establishing a relief camp in Thangal Bazaar marks this space as a safe haven for non-Manipuris. The growth of the non-Manipuri community in this part of the city can be traced back to the British era (Singh, 1998: 183-84). As a recognised area of the city for non-Manipuris it is where new migrants from outside the borderland arrive and seek information, food, and temporary accommodation. There is a high concentration of non-Manipuri businesses, places of worship, and schools. When I visited it during my early periods of fieldwork, prior to the escalation of the ILP issue, it felt like a discreet zone within the city, an island of tolerated necessity for supplying the city with goods and cheap labour. As a relief camp the boundaries hardened between the area around Thangal Bazaar, where non-Manipuris could exist as a majority, and the rest of the city 'out there' where their presence is noticeable and temporary in neighbourhoods, markets, and colleges.

The relief camp represents a crisis point in the ILP where exclusion of non-Manipuris took material form in a camp under police guard. Even in the weeks and months around this crisis point, non-Manipuris continued to work and look for work in the city. Long-standing businesses continued to operate, though not without incident or fear. Streets corners on main roads were still frequented by non-Manipuri day labourers, some with paint rollers, some with harnesses for construction sites, some with a few tools. Their existence during this period was no doubt chronically insecure, but in many ways life at this end of the economy is perpetually insecure and worse without work.

In an era of connectivity that has transformed the borderland from a frontier to a corridor and recalibrated Imphal as the major urban centre through which goods and people flow between Southeast Asia and South Asia, the demands for the ILP reveals the limits of connectivity and the desire for exclusion. Imphal is the epicentre of a counter-movement to control the mobility and activity of a certain group of people. What does the demand 
for the ILP reveal about Imphal - about space, belonging, and exclusion? As discussed in the previous chapter, the armed forces and the civilian government control urban space from the top down. This control is contested by residents who reclaim space for memorials and rituals and by the creation and maintenance of place in neighbourhoods. The ILP further demonstrates the ways that residents seek to control space by excluding non-Manipuris from the city, evicting those deemed illegitimate, and controlling the movement of the rest. Action by organisations and volunteers is deemed necessary in the face of inaction, or insufficient action, by the civilian authorities. In this context residents take spatial control into their own hands.

However, there are alternative ways of reading this. The ILP movement is a challenge to the Indian Constitution and the conditions under which Manipur was made part of the Indian Union. Manipur may be part of India but supporters of the ILP challenge the inclusion of their territory in a national zone of free movement and settlement. The fact that advocates seek a resolution through the imposition of a colonial law is testament to the lack of options for ensuring territorial control in the borderland. The ILP movement has also provoked an adjacent argument about whether Meiteis could be included as Scheduled Tribes and therefore be excluded from Article 19 and exercise their own territorial control over the valley areas of the state. The argument for tribal status is also part of a drive for greater recognition of Meitei as indigenous people, as having 'mongoloid' features, as having pre-Hindu religious traditions, and as Tibeto-Burmans like most, but not all, of the tribal communities of the borderland (Haokip, 2015). It is the colonial category 'tribal' that has denied this form of recognition.

\section{Conclusion}

In excluding the non-Manipuri population from the city, the ILP issue also constructs the notion of a shared indigenous identity, or at the very least a sense of who is legitimately entitled to dwell in the city. Whether intentional or accidental it constructs the parameters of Manipuri identity and affixes these to the territory of the present federal state boundaries. Membership of this category grants the right to the city. The indigenous Manipuri category, and perhaps a genuinely felt shared identity among those subject to it, questions interethnic hierarchies and rivalries. It also makes for an interesting comparison to the blockades discussed above. During the blockades the fissures between tribal and non-tribal communities were at the heart of attempts at spatial control on a different scale, between hill and valley. 
Imphal is small. Within five years there were two lengthy blockades of the city that inflamed interethnic tensions and a broadly supported drive to evict non-Manipuris from the city. The blockades divided the indigenous population in the city; the ILP issue brought these communities back together, perhaps not in a deep or substantive sense, but at the very least in an instrumental sense. It also brought other marginal groups into the fold. A striking example was the sit-in protest by members of Imphal's transgender community at Sagolband Salam Leikai in the southwest of the city in late August 2014 in support of the ILP (Khangembam, 2014b). As might be expected, the community lives a marginal existence. In an environment with strict codes of moral behaviour and gender roles, transgender resident in Imphal can find themselves with limited economic prospects outside the beauty and fashion industries, as the targets of violence and sexual abuse, and with difficult relationships with families, clans, and tribe. To publically identify themselves as a community and as supporters of the ILP was a remarkable manoeuvre, simultaneously legitimising the community, their presence in the city, and their position in favour of the ILP. To put it another way, the transgender community was able, even fleetingly, to become part of mainstream Manipuri society. At the sit-in at Sagolband Salam protestors held signs commonly seen at other sit-in such as 'Save Indigenous People of Manipur', 'We Support ILP', but also others clearly identifying themselves, such as 'We Are Transgender People [Who] Strongly Support ILP in Manipur', and 'We Do Not Want to Be a Minority'. The last one may have been referring to the claim of the ILP movement that indigenous Manipuris will become a minority in their own lands, but when held in the hands of a transgender protestor it also contains a further statement about inclusion and the unexpected pathways to belonging. 

Part 2

Liberalising the Frontier 



\section{Gateway City}

In downtown Imphal there is a major intersection where five roads meet near the Khoyathong Pukhri Achouba, a large public pukhri and important landmark. The traffic circle is busy during the day and usually staffed by local police in a small shelter raised above the traffic. It is a major route for the city's auto-rickshaws taking passengers to and from the market. To improve traffic flow, ropes and steel barricades are used to block off certain streets at different intervals. Police threaten disobedient drivers with bamboo sticks, though the threat can be muted by subtly dropping some rupee notes on the road near the police post. There are also several eateries and pharmacies clustered around the traffic circle, feeding the dual addiction of the city's youth to fried chicken and Spasmo Proxyvon. A short stretch of road joins this traffic circle to the main highway to Myanmar where there is also a traffic circle with a police shelter, known as LIC point after the Life Insurance Corporation of India building on the corner. This is the main entry point for vehicles bringing goods from outside the city into the market area. The flows of cars, bikes, rickshaws, bullock carts, tractors, and trucks (though they are supposed to go by a different route) cause traffic jams throughout the day. All of this makes it a crowded and slow-moving patch of the city - the perfect place for large billboards and a patch I return to often during fieldwork to look at what is being advertised; from watermelon festivals to fashions shows to new private schools.

In recent years private telecommunications firms, such as Airtel and Aircel, have covered much of this patch with signage. They have even branded the police traffic shelter, taking turns it seems to have their logo above the harangued officer on duty. An enormous billboard for Dalmia Cement featuring Mary Kom, the Olympic boxing medallist from Moirang about 45 kilometres away, with the slogan 'Our Kommitment to the Nation: now in the Northeast' has featured at different ends of this stretch. Mary, a national celebrity but with local roots, features, and status is the perfect messenger for a national firm trying to crack the Northeast market. Cement is a competitive industry given the desire to cover much of the borderland in it and given that the region hosts a successful cement firm, Star Cement, out of Meghalaya which has used Northeast musicians such as the late Bhupen Hazarika, Mami Varte, and Lou Majaw in its advertising. Northeast faces on advertisements for national brands is perhaps unsurprising given the desire to access the consumer markets of the borderland. Billboards featuring Indian celebrities are more unusual - though there are a few in the 


\section{Image 5.1 Billboard featuring Mary Kom, Khoyathong}

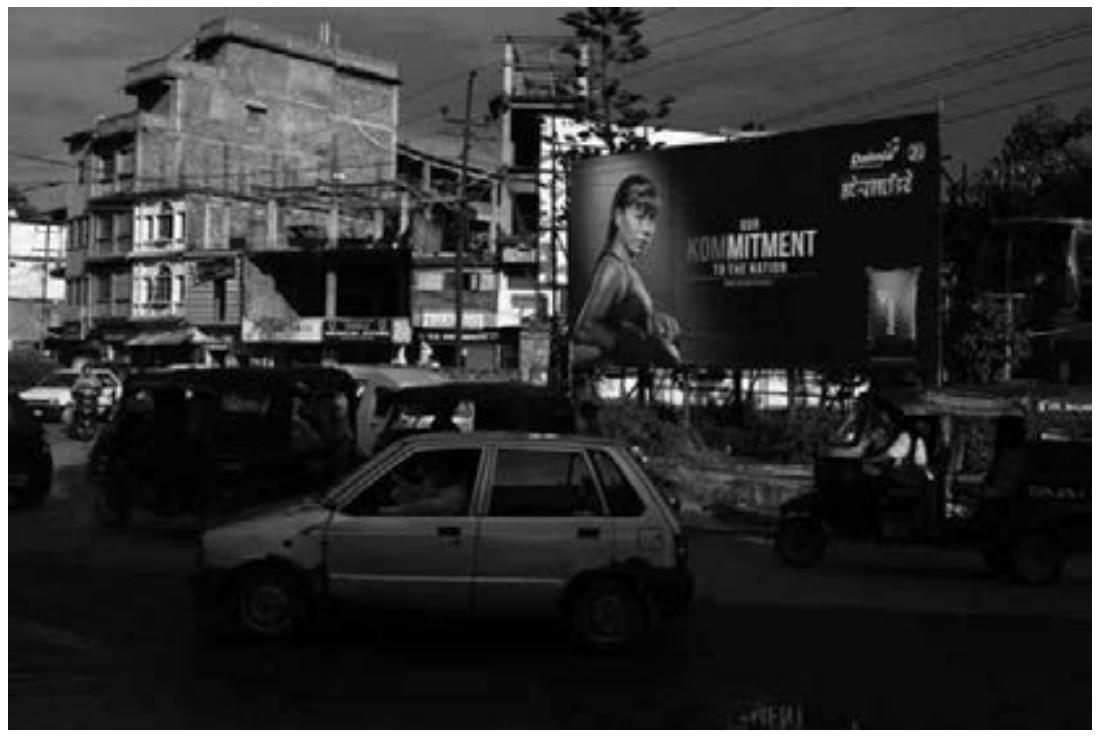

main commercial areas on advertisements for soap, phone companies, and banks. As with all signs in Imphal, whether featuring a Northeast singer or a Bollywood star, the logo and slogan that one would see elsewhere in India is accompanied entirely or in part by a translation in Meitei and written in the Meitei Mayek script. It is very uncommon to find a sign without Meitei Mayek script somewhere on it, and those without it don't last long and are dismantled by ethno-nationalist groups.

The frontier is liberalising, or being liberalised. Indian capital is gaining a firm foothold. On arriving in Imphal the barrage of Airtel signs, the signal on my cell phone handset, and the money I use to recharge it indicates that I am in India, but the Meitei Mayek script on the billboard that reminded me to recharge, the unique script on the familiar blue and green sign of the State Bank of India identifies the ATM where I withdraw cash, and the sign on the kiosk where I bought the voucher remind me that I am in Manipur. Localisation of national advertising is common elsewhere in non-Hindi-speaking India, but in Imphal it is required. And it is enforced from below. Liberalising the frontier requires concessions. Groups enforcing the use of the script demonstrate a form of spatial control and make a claim to sovereignty by marking the landscape.

This chapter begins part two of the book. Part one explored spatial control and contention in Imphal through belonging, control and exclusion. Part 
one sought to sketch life on the ground in the disturbed city, and to relate it - loosely - to the idea of sensitive space and the 'interwoven projects of rule', to return to Dunn and Cons' phrase, experienced and contested by residents. In the disturbed city where sovereignty is fragmented and diffused among state, non-state, and quasi-state actors, creating and maintaining place is challenging. Yet in the neighbourhoods, memorial sites, and drinking dens of the city a sense of place is possible. Part two focuses on dual connectivity and the ways this shapes the disturbed city and vice versa. In the chapters that follow I argue that flows east, to and from Southeast Asia, and flows west, to and from India are harnessed, pursued, and localised in ways that counter the state-directed connectivity project. At the core of the chapters in this section is recognition that Imphal, and to an extent other parts of the borderland, are no longer - if they ever were - isolated frontiers. Imphal is being recalibrated in the context of dual connectivity with deep impacts on the city, its landscape, its people, and its diaspora. Part one sought to draw out the highly localised politics of a borderland city that has experienced decades of militarisation. Part two asks what happens when this city is subject to greater connectivity across the nearby international border and inwards deeper into the nation-state from which many of its residents have sought secession.

This chapter analyses the recalibration of Imphal as a gateway city to Southeast Asia and to India under the Look East, and later Act East approach of the Indian Government. The gate opens in both directions. Imphal's geographic location, for so long used to justify military intervention in the 'troubled periphery' (Bhaumik, 2009), now sees it re-imagined as a key node along a corridor connecting the dynamic economies of Asia. Yet I am not solely interested in the connectivity project from the 'top down' but the ways connectivity takes local forms and the ways the state-led project to create a gateway city is challenged from the 'bottom up' in ways that reflect the fragmented sovereignty and diffuse counter-hegemony discussed in part one. Official discourse on connectivity focuses on the potential of the borderland, and of Imphal, in this new regional order. Imphal is a potential generator of economic growth and a potential consumer market. Yet realising this potential requires the paternalism of the Indian state and willing local governments capable of creating an environment for investment, an environment that requires stability, security, and financial incentives. In this chapter I compare the official discourse seeking to create a gateway city in Imphal with local practices that reshape connectivity amidst the politics of the disturbed city described through three examples: the campaign for Meitei Mayek script on all public signage, the clothing trade as 
a way of utilising connectivity to make do, and the attempts to block the ASEAN-India car rally. These three examples offer alternative perspectives on the gateway city from different non-state actors and show, in turn, the opportunities connectivity affords for these actors to make sovereign claims in the face of market expansion, to adopt new livelihood strategies, and to bargain with the state.

\section{New India and Its Frontier}

Harvey defines neoliberalism as 'a theory of political-economic practices that proposes that human well-being can be best advanced by liberating individual entrepreneurial freedoms and skills within an institutional framework characterised by strong private property rights, free markets, and free trade' (2005:2). The role of the state is to provide the institutional structures to support this and guarantee the functioning of markets. This process has led to what Harvey terms 'creative destruction' of previous institutional frameworks, divisions of labour, social relations, and welfare provisions, among other things (2005: 3). Neoliberalism in India - usually referred to as liberalisation and closely tied to the maturation of India's democracy (Kumar, 2008) - has been undertaken in uneven and often paradoxical ways since 1991, driven by internal and external political forces and has been analysed at length from scholars in a number of disciplines (see Aghion et al., 2008; Bhaskar and Gupta, 2007; Corbridge and Harriss, 2000; Kohli, 2006; Sengupta, 2009). In a general sense, liberalisation has compelled a shift in the role of the state as provider under Nehruvian socialism to a champion for private investment and market penetration, albeit with extreme variation at the federal and local levels and in different sectors of the economy and society. Liberalisation in India contrasts 'old' Nehruvian India and 'new' liberalised and globalised India - at least rhetorically and symbolically (Kaur, 2012; Kohli, 2012). In practice, liberalisation measures are undertaken with parallel growth in new regulation and reregulation in certain sectors and by certain subnational authorities, particularly federal state governments (Hsueh, 2012; Jenkins, 1999). Academic focus on new India produces a fascination with consumerism, workplace cultures, the middle classes, diaspora, and popular culture on the one hand, and the ascendency of corporate India, special economic zones, resource extraction, and new inequalities on the other (see Fernandes, 2006; Ganguly-Scrase and Scrase, 2009; McCartney, 2010; Oza, 2006). As Gupta and Sivaramakrishnan argue, the focus of much scholarly attention on neoliberalism in India has 
been more about the 'decline of the developmental state than about the state that is emerging in its place' (2011:3). With this in mind I am interested in the form liberalisation takes in the borderland, specifically Imphal. Within the vast quantity of literature on liberalisation in India there is little consideration of the borderland, where state presence appears firmly embedded in the security apparatus, systems of parallel governance, and strategic state-led development and economic dependency. Thus the push for liberalisation receives very little grounded analysis (see McDuie-Ra, 2009b).

The internal borders of the Northeast region have been rearranged several times in response to violent and non-violent agitations between 1963 and 1987, though arguably the formation of the Bodo Territorial Council within Assam in 2003 signals another phase in internal reorganisation. The creation of small dependent units has been termed 'cosmetic federalism' by Baruah (2003), referring to the granting of a formal federal statehood by the Indian state, while at the same time ensuring a high degree of control over these units. Military and political control are discussed in part one of this book; here my focus is the economic relationship between the Indian state and Manipur.

Manipur's economy has a low level of industrialisation. Agriculture comprises $32 \%$ of net state domestic product and employs over $50 \%$ of the workforce (Manipur Commerce and Industries Department, 2013). The economy is characterised by high unemployment, low public and private finance in both agricultural and industrial sectors, miniscule tax revenue, infrastructure challenges, corruption - fed in part by the security approach of the Indian Government that seeks to cultivate loyalty among local elites as well as the local malaise, reliance on exchange rather than production, and the second-worse electricity supply in India (after Jammu and Kashmir) (Manipur Commerce and Industries Department, 2013; Manipur Directorate of Economics and Statistics, 2007). According to the Reserve Bank of India, Manipur's fiscal performance is the second worst in India, behind only Arunachal Pradesh (Reserve Bank of India, 2014: 34-35, 42-43). Manipur is considered a 'special category state' and depends on finance from the centre for its annual budget transferred directly (as much as $89 \%$ ) and also in the form of grants, loans and other schemes coordinated by the Ministry of Development of North Eastern Region (MDONER) and the North Eastern Council (NEC). Funds released to special category states are $90 \%$ grants and $10 \%$ loans payable over 20 years - very attractive terms for state governments like Manipur. In the period 2010-14 Manipur also received funds from Delhi for infrastructure development under the Border Area Development Program, 
the Non Lapsable Central Pool of Resources, and the Special Assistance Plan (Manipur Planning Department, 2015). Clearly, Manipur is completely dependent on India, economically. Thus to what extent can the state be seen as shifting or even retreating in the face of liberalisation in Manipur?

A brief discussion of the official discourse on liberalising the frontier is needed in order to contrast it with localised practices 'from below', as it were. The opening of the border with Myanmar in 1995 did little to allay a sense within Manipur that dependency on the Indian state - and the security priorities that underpin this dependency - was the main driver (or saboteur) of its economic fortunes (Sharma, 2009). In contrast, new India enables a vision of a new Northeast constructed through the twin tropes of potential and paternalism. Imphal is embedded within a larger imagination generated in Delhi and reproduced, with some variation, in the state capitals of the borderland. Unlike other parts of India where land, coasts, rivers, and forests have been exploited, the Northeast is imagined as almost virginal; a place full of valuable resources that local people cannot, or will not, utilise. The potential for growth and profits are concentrated in extractive industries and, somewhat contradictorily, ecology and biodiversity. Federal states like Manipur are encouraged to tap this potential by courting private investment.

For example, at the North East Business Summit, an annual meeting organised by MDONER and the Indian Chamber of Commerce (ICC), representatives from the state governments in the Northeast meet with potential investors and seek to 'sell' their state. The briefing report produced for the 2013 summit by the ICC and global finance firm PricewaterhouseCoopers, India's North East: Diversifying Growth Opportunities (ICC/PWC, 2013), features an image of a car park in Spain on the cover - presumably to imply the potential for cement-based infrastructure. It also reflects the aspirational statements bandied about in the Northeast and in Delhi, such as: 'As multiple avenues for growth and development emerge, it is of paramount importance that the region, as a collective identity, embarks on a vibrant journey to realise the dreams of a better future' (ICC/PWC, 2013: 2). There is an attempt to differentiate among the states. For example, 'All the eight states have different developmental prospects and resources to support their efforts in contributing to the regional as well as national economy' (ICC/PWC, 2013: 5). Throughout the briefing report states are compared based on their level of food production, forest cover (the less the better as it implies more farm land), fertiliser use (the more the better), agricultural productivity, length and type of road (measured through a road-density index), length of railway, power-generating capacity, and education levels. 
The Northeast's proximity to international borders is also a sign of great potential for investment commonly referred to as India's Look East Policy built on the post-Cold War foreign policy of former Prime Minister Inder Kumar Gujral (Murthy, 1999; Yahya, 2003). It is very difficult to escape the term 'Look East Policy' in Imphal where it has become a metaphor for new economic opportunities, border crossings, a staple of media reports and political speeches, and part of the language of savvy elites. Barely a month goes by without a seminar, forum, or briefing framed by the term in the assembly, at the university, or in one of the city's hotel conference rooms. Within the Look East Policy, Imphal is seen as the gateway to Southeast Asia and from Southeast Asia to India. The policy has evolved through a number of key documents and political champions.

The Look East Policy is expanded upon in the flagship North Eastern Region Vision 2020 (NEV2020) policy document written by MDONER and released in 2008 (MDONER, 2008a, 2008b, 2008c). NEV2020 pushes cross-border trade as a way to alleviate poverty and create new opportunities. This is seen a way of fixing the geography of Partition and 'opening' the landlocked borderland to markets with apparently insatiable appetites for goods produced in Northeast states. As I have argued elsewhere (McDuie-Ra, 2009b), the NEV2020 agenda contains contradictory imperatives of promoting mobility across international borders while also seeking to further state (in this case central state) control of territory through formalising cross-border trade through legalised crossings, customs posts, permanent border demarcation, and border fencing.

The report refers to 'underdevelopment' as the region's 'economic imprisonment' (MDONER, 2008b: 260, 274) and argues that to achieve peace in the region a 'paradigm shift in development strategy' is needed towards 'people-centric programmes based on harnessing the natural resources of the region' (MDONER, 2008a: 18-19). At the crux of this 'new development paradigm' are exploiting the region's natural resources, gas and petroleum reserves, hydropower potential, creating an hospitable climate for investment, border trade, and undertaking significant amounts of public investment in infrastructure (MDONER, 2008a, 20-21).

Potential requires a paternalistic central state to manage liberalisation. Federal states are called upon to provide the following: 'Free and unhindered mobility of goods and services (infrastructure) across the region as well as within the region; well-defined property rights; and law and order and security of life, such that markets can function and reflect the true scarcity costs of goods and factors' (2008b: 282). NEV2020 sets the normative framework for guided liberalisation by the benevolent central government; however, there are other mechanisms to help enact this process. The North East Industrial 
and Investment Promotion Policy 2007 (NEIIPP) is an initiative of the Cabinet Committee on Economic Affairs funded from 2007 to 2017 to encourage private investment to transform the entire Northeast into a Special Economic Zone. It provides incentives for private investors (mostly for a ten-year period) for new investments and for the expansion of existing investments including: $100 \%$ tax exemption, $100 \%$ duty exemption, up to $30 \%$ capital investment subsidy, interest rate caps on loans, insurance reimbursement (a major incentive in the Northeast where firms fear instability and violence will ruin their ventures), and special incentives for the services sector, biotechnology, and power generation (CCEA, 2007). Finance is coordinated through the North Eastern Development Finance Corporation (NEDFi), established in 1995.

The Industrial and Investment Policy of Manipur (2013) is based on the NEIIPP and offers the same basic subsidy levels with an additional 21 subsidies and exemptions covered by the Manipur Government. Of particular interest are capital subsidies for any enterprise set up within 40 kilometres of the international border, various offsets to the costs of additional finance (such as interest rate and stamp duty subsidies), power subsidies, transport and storage subsidies for small producers and for perishable goods, and seven years of exemption from Manipur value added tax.

The incentives for investors are extremely attractive, but uptake of the policy and the finance is low (see McDuie-Ra, 2014b). The first report on the NEIIPP in 2010 showed only one project receiving funds in Manipur, and that was a transport subsidy for a rice mill (MDONER, 2010: 244). In the five-year period 2009-13 only five memorandums were filed in Manipur, the first step to applying for and securing NEIIPP funds (Ministry of Commerce and Industry, 2014: 230). Notably Manipur has a large number of registered micro, small and medium enterprises which are supported through a different scheme - though still less than neighbouring states (MSME, 2014). The NEIIPP was suspended indefinitely in late 2014 .

Violence, extortion and instability are obvious disincentives, indeed NEV2020 reflects this view: 'Many of the problems of the region stem from weak governance, which has contributed to the rent-seeking, "easy-money" culture, and created a law and order situation which has deterred investment' (MDONER, 2008a:19). However, the sheer number of different actors, institutions, and visible and invisible partners in any venture makes it difficult to pinpoint where the breakdowns occur and indeed in whose interests liberalisation takes place. Alongside conventional political and business elites are figures of traditional authority, high-ranking members of the military and security establishment, and leaders of underground and ethno-nationalist groups who can also profit from preparing or enabling (or choosing not to 
obstruct) ventures. Members of the armed forces are participants in land deals, black market trade, and smuggling. Occasionally they are caught, as in February 2013 when Colonel Ajay Choudhury, the Public Relations Officer of the $57^{\text {th }}$ Mountain Division, was caught in Manipur smuggling pseudoephedrine tablets into Myanmar (Laithangbam, 2013). The reality that a high-ranking army officer was involved in smuggling was unsurprising; it was the fact that state police caught him that really made news in Imphal.

Ministers and bureaucrats go to lengths to demonstrate to Delhi that they are taking the prescribed measures to make Manipur more investor friendly by hosting trade fairs and investment forums, and by formulating new industrial policies. By demonstrating intent politicians can seek further financial support and/or recognition from Delhi. To put it another way, by showing willingness and openness to private capital, the state government can make claims to (more) public capital. For would-be investors, buying into the rhetoric of potential and pledging to invest in the region can enable access to subsidies and incentives. Actually implementing the promised investment is another matter. And it can always be abandoned due to instability or extortion. Performing a long preparation for liberalisation can be as important as actually liberalising.

Following the election of the Bharatiya Janata Party (BJP) led by Narendra Modi to the office of Prime Minister in 2014 - seen as an endorsement of aggressive liberalisation modelled on his time as Chief Minister of Gujarat (Chhibber and Verma, 2014) - the Northeast borderland is once again touted as a site for intensified market penetration, an untapped consumer market, and a gateway connecting India to Southeast Asia and China. In 2014 the Look East Policy was re-launched as the 'Act East Policy' following Modi's visit to Myanmar. Modi said of the shift, 'a new era of economic development, industrialisation and trade has begun in India. Externally, India's "Look East Policy" has become "Act East Policy"' (Modi in Parameswaran, 2014). While his supporters gush over the proactive turn, what exactly differentiates the new approach is difficult to determine beyond further commitment to infrastructure development and connectivity. The former Indian Ambassador to Myanmar, V.S. Seshadri, wrote in the national newspaper The Hindu:

There can be mutual benefit if both India and Myanmar can work together to truly transform the evolving connectivity corridors into development corridors ... [I]t will be useful for the two sides to discuss the required soft infrastructure - transit and transport agreements, the necessary border trade and warehousing arrangements and how to ready the businesses for the new opportunities. Both sides have a strong interest in expediting these projects. They can bring significant benefits to the Northeastern 
States of India and the western part of Myanmar that is also much less developed. Effective trade and transportation links can improve market size for potential investments. This can further build on the border region development projects being undertaken by India in the Chin state and the Naga-administered zone of Myanmar. (Seshadri, 2014)

Despite the shift from looking to acting, the scenario is discussed in almost identical terms to the NEV2020. Regardless of actual content, or lack of it, the centrality of connectivity in Delhi's approach to the borderland ensures it will be on the agenda through the coming decade. Writing in The Diplomat, Downie argues that despite the complex array of factors undermining the potential of cross-border trade, persistence by the Indian Government may 'shape the behaviour of, the various players of Manipur's political economy - interest groups in the central government itself, state authorities, the security establishment, and local underground and civil society players' (Downie, 2015). He adds, 'the benefits could be enormous: a more stable and prosperous Manipur, emerging overland trade corridors to ASEAN, and new diplomatic leverage in East and Southeast Asia for other priorities. That is truly Acting East' (Downie, 2015). In this scenario the strong hand of the Indian state is needed to disciple the unruly border polity and help its denizens pursue their potential.

In addition, liberalisation of the borderland casts the region as a market full of consumers. For example, the Indian automobile industry has the Northeast in its sights as a growing market, as does retail, hospitality, education, airline, telecommunications, and information technology industries. Society of Indian Automobile Manufacturers Deputy Director General Sugato Sen is quoted in the Economic Times as saying 'the North Eastern market is very fertile. I think the future of this region is very bright. Opportunities are there for auto makers' (Economic Times, 2013). As a market for consumer items, the Northeast is another kind of frontier, the last domestic market to crack.

Consumption brings peoples of the borderland into the common domestic market and into equivalent standing with other citizens. A 2013 article in the business media outlet Live Minit, which also produces and distributes the Indian edition of the Wall Street Journal, presents a typical articulation of this view. The article begins with the following: 'India's Northeast is known for its tropical rain forests, tribal cultures and handicrafts, Assam tea, flaming hot peppers and outbreaks of ethnic unrest. Now, the region is emerging as a magnet for upscale apparel and accessories labels that are 
seeking to tap the growing demand in states such as Assam, Tripura and Manipur' (Tandon, 2013). The article goes on to quote a representative of L'Oreal in India who states 'Consumer behaviour in these states and the level of awareness is similar to that of the big cities' (Ghosh in Tandon, 2013). A consultant from PricewaterhouseCoopers adds, 'It's a brand-conscious and fashion-forward market. So it's a natural progression for fashion brands to get there' (Nath in Tandon, 2013).

When the Northeast is discussed as a potential market it is usually Assam that is being referred to rather than states like Manipur. This is unsurprising given Assam's accessibility and population of 30 million. Its largest city, Guwahati, hosts the Northeast Consumer Awards founded in 2010; an initiative sponsored by the Apex Body of Industry Indian Chamber of Commerce and several media outlets including the Hindi-language daily Dainik Purvoday. The 2013 awards, based on survey data among consumers, recognised the achievement of firms like the State Bank of India, Tata, Airtel, and Britannia for their success in selling lots of things to people in the region. In a cover story, Northeast Today magazine reported glowingly on the awards as 'a unique way of saluting those brands that have caught the imagination of [the] aspiring generation of Northeast India', and pointed out 'the vital role that consumers play in the advancement of our Northeastern economy' (Northeast Today, 2014). Through consumerism and the penetration of big brands to the region, Northeast people are viewed as equivalent citizens, part of a common domestic market. To paraphrase the L'Oreal spokesperson quoted above, it makes them similar to people in big cities elsewhere in India - quite a change from 'tropical forest dwellers' prone to unrest.

\section{Indigenising Indian Capital}

What does the expansion of the domestic market look like in the disturbed city? If the borderland is seen as a new frontier for Indian business, how does this function in the urban landscape of Imphal? To put it another way, how is new India manifested in the landscape of a city where old India is resisted? Here I return to the enforcement of the Meitei Mayek script discussed at the start of the chapter as an example of the ways Indian capital is subject to local politics of place, ethnicity, and claims for sovereignty.

The main organisation demanding and enforcing the use of Meitei Mayek is the Meetei Erol Eyek Loinashillon Apunba Lup, Kangleipak (MEELAL). MEELAL has been at the forefront of a movement to revive Meitei Mayek and eradicate the Bengali script that had become the main written form of 
Meiteilon, the Meitei language, over the last century. The Manipur Government approved a standardised Mayek script for 're-introduction' in 1980 (Manipur Gazette, 1980). Re-introduction was slow during the 1980 s and 1990s: it was not a compulsory part of the school curriculum, it wasn't a prerequisite for government employment, there were few qualified teachers, and few printing presses featured the script. The ban on Hindi in 2000 provided a boost for the indigenous language campaign and accelerated the campaign for the Meitei Mayek script.

On April 13, 2005, members of MEELAL and the Kangleipak Communist Party, one of Manipur's underground groups, protested in favour of the implementation of the script. They gathered outside the Manipur State Central Library, a repository for historical records of the Manipuri Kingdom. The library is located between two heavily fortified buildings, the Raj Bhawan (Governor's Residence) and the Electricity Department. Local media reported 20 people entered the library and 'poured kerosene over every available paper materials and books from about ten jars before setting them afire' (Sangai Express, 2005). The library was severely damaged and many historical documents were lost. Two suspects were arrested nearby, both Meitei Mayek teachers. Donating to rebuild the library has since become a philanthropic norm, with diaspora associations, the Assam Rifles, antiAFSPA activist Irom Sharmila, and others giving money or books.

The fire was widely reported in the national and international media. The tone of the coverage intimated that barbarism was at work. A BBC report on the fire included a quote from prominent Manipuri lawyer Koteswar Singh who labelled it a 'Taliban-style act' (Bhaumik, 2005), the New York Times spoke of a 'mob' (Sengupta and Kumar, 2005), and the Asia correspondent for The Economist referred to the library fire as the work of 'fascist loons' (2007: 50). A month after the fire the Manipur Government agreed to implement Meitei Mayek in the school curriculum from Class 1. This date (May 18) is celebrated annually in Imphal and prizes are awarded to the school children in Meitei Mayek writing competitions. In less than a decade the outrage at the attack on the library has turned into a cultural celebration.

MEELAL has been very successful in getting the print media, advertisers, and government departments to publish in the Mayek script alongside Bengali or Latin scripts. New technology has also enabled the script to spread: Mayek apps are available to download onto smartphones, the script can be downloaded onto computers, and some locally made mobile phone handsets feature Mayek keypads (while I have seen these in person, I have not yet been able to track down the manufacturer). Yet there is still a fundamental problem in that many people can't read the script. This leads 
to the curious situation of school age children being able to read signage and media that older people cannot. To address this MEELAL offers Mayek courses throughout the city. Morning and evening classes are advertised on posters (written in Latin script) in markets, neighbourhoods, and outside colleges. These are accompanied by a slew of free online tutorials and resources, many available through the E-Pao media platform. As a result, public use of the Bengali script has reduced noticeably in Imphal, though change is a little slower outside the city. In the hills the Bengali script was rarely used in the first place.

The power of MEELAL is boosted by its alignment with other movements: Meitei ethno-nationalism in its various guises, the ban on Hindi language, and the ILP movement discussed in the previous chapter. Like these movements there is a certain level of anxiety about connectivity underpinning the campaign for the script. The idea of a vulnerable and vanishing culture is crucial to their message. Connectivity opens the gate - metaphorically and materially - to new forms of cultural domination as well as reinforcing old ones that altered the culture in the past. MEELAL has campaigned for all communities indigenous to Manipur to be educated in their own languages; and thus they have positioned themselves as protectors of vulnerable cultures of all indigenous groups in Manipur. This has seen MEELAL turn its attention to all 'alien languages', even suggesting books written in any Manipuri language featuring 'alien words' be banned (Sangai Express, 2013a). For a time volunteers were confiscating such books from Imphal bookstores.

English is on MEELAL's radar, however, unlike the campaign against Bengali script that sought eradication, MEELAL seeks a balance between English and Meitei on all public signage. In 2012 MEELAL set an August 27 deadline after which no signs using only English would be allowed. MEELAL activists and volunteers have enforced this ban. For instance, in October 2013 at a product expo funded by the Industries Development Council and the United Nations Development Program, over 30 banners were burned for not including Mayek and the expo was shut down until organisers complied (Sangai Express, 2013b).

The compulsory use of Meitei Mayek shows the ways the urban landscape is marked, claimed, and reclaimed as Manipuri territory. It shows the ways in which liberalisation in the frontier is to be negotiated with non-state actors according to their vision about the place of the city and the polity as a sovereign territorial unit distinct from India. In her study of political graffiti in West Bengal, Chattopadhyay explores the 'territorial implications of wall writing' as 'a sort of visual disorder, one that refutes a given order of 
the city' (2012:128). Chattopadhyay sees this as a largely positive exhibition of subaltern activity 'by crafting a political vernacular that is different from the proper language of the state or civil society' (2012:132). It helps to create political subjectivity through a 'specific form of publicness' (2012:138). Born out of the spectacular act of burning down the State Central Library, the compulsory use of Meitei Mayek refuted the old visual order of the city and ushered in a new one. Unlike the political slogans discussed by Chattopadhyay, the new visual order in Imphal places little importance in what is written - indeed everything from washing machine advertisements to spirithealing announcements appear in Meitei Mayek - and every importance on the script in which it is written. The script distinguishes this place from others, this territory from the nation-state that claims it, and the people who can read it from the other inhabitants of the city. Everyone must comply, from the national telecommunications firm to the small tailor's shop.

The issue of the script would come up in conversations with friends and respondents during fieldwork in Imphal. Some are supportive, seeing no other way to reintroduce an otherwise lost element of Manipuri culture, some are more circumspect and fear the consequences and implications for policing other aspects of everyday life, some are bemused at the fuss and don't give it much thought, some seem resigned to it; after all, much worse things have happened in the city in living memory. Friends would often joke about not knowing the Mayek script, or make a big show of asking kids to read things for them, or wonder aloud what other things from the past will also become compulsory for Imphal residents. Others talk about the political economy of the Mayek movement - creating work for hundreds of transcribers and inspectors. Occasionally friends from non-Meitei communities would raise the script as an exemplar of valley domination, though this view was not as common as I imagined. As one friend from the Vaiphei community, one of the smaller hill ethnic groups, put it to me, 'I never learned the old one, so I doubt I will learn this one'.

The compulsory use of Mayek illustrates a spatial imagination, whether broadly or narrowly shared, that connects the contemporary urban landscape to an historical polity - the Manipuri Kingdom prior to external intervention, and to aspirations for future sovereignty. This spatial imagination challenges the vision of connectivity shared by proponents in the Indian Government and businesses seeking to enter Manipur. Seeing the script marking otherwise uniform content with the cultural graffiti of ethnonationalism helps to produce and reproduce a place-based subjectivity. It may not vanquish the armed forces or the Indian state, but it does force recognition of past, and possibly future, sovereignty. 


\section{Gateway Livelihoods}

The official vision of large infrastructure projects, industrial development close to the border, and high-volume legal cross-border trade is slow in coming. While the focus of government at various levels is on creating an investor-friendly environment, residents are taking advantage of connectivity to find new ways of making do. One of the most conspicuous livelihood strategies is involvement in the clothing trade. Connectivity opens up new possibilities for making a living, or a supplementary income, by selling clothes in Imphal. While this trade is a far cry from the imagined benefits of connectivity promoted by the NEV2020 and the Look East Policy, it has transformed the urban landscape in various patches and characterises dual connectivity of the borderland city for its poor and middle-income residents. Bales of clothing come through India, mostly Kolkata, and from the border with Myanmar at Moreh, much of the latter from Namphalong Market on the Myanmar side of the border.

Second-hand clothing is sold almost everywhere in the city. At times it appears whole localities have been given over to the trade. In the dry season rows and rows of bamboo racks are lined up in front of shops, along pavements, between telegraph poles and in unused or un-open lots along main roads, such as Konung Mang Road, a main north-south thoroughfare through the city. Jim, a friend who lived in Checkon (a locality on one side of the road), remarked once when we were driving through the area, 'there are enough clothes here to clothe the entire world'; as if even living among it did not halt his disbelief. There are designated second-hand clothing markets such as Independent Season Market at Kangla Lambi, areas with clusters of second-hand vendors in permanent shops such as in Paona Bazaar opposite the Mapal Kangjeibung (Polo Ground), spaces that have become secondhand clothing markets without any official status such as the courtyard in front of the Rupmahal Theatre or the grounds of the Manipur Public Library (not the same one that was burnt down), and hundreds of street vendors who move around the city, occupy territory temporarily (though sometimes regularly), and navigate the various state and quasi-state actors who seek to control space in the city and will fine, imprison, beat, and blackmail them.

During fieldwork I spent time with second-hand clothing traders in different locations. I sat around in shops in the main bazaar areas talking and snacking, I visited temporary and seasonal markets that popped up and disappeared again, I met middlemen and wholesalers, I visited storehouses for the vast number of bales, and I witnessed licence checks and associated extortion among mobile vendors. I spent the most time in a shop run by 
Dipen located in Paona Bazaar near the now empty Friends' Mini cinema, which also doubles as a storehouse for second-hand clothing wholesalers described at the start of the book. The demise of the cinema after the ban on the Hindi language emptied the space, and the demand for second-hand clothing from the West and Asia has filled it again. The whole area is popular for second-hand clothing. Shops such as Abethoi's Korea Market and City Second Hand Market at the Manipur People's Party Shopping Complex ensure a steady flow of customers.

Dipen's shop is made from wood and is raised a foot or so off the ground. Inside there is enough space for him and one or two others to sit among the piles of clothing. The best items are displayed on hangers around the inside and outside of the shop and folded at waist-height at the front of the shop facing the street. Dipen was a veteran of the industry whose career in clothing corresponded to the opening up of the city in the 1990s. He started out selling second-hand clothes in 1997. His first spot was in the public library grounds. Later he was part of a group of vendors who lobbied to get the space in the Manipur People's Party Shopping Complex before going out on his own. He has seen many vendors come and go over this fifteen-year period. Almost everyone has given it a try; even (allegedly) a famous Manipuri film actor, Bonny (Gurumayum Bonny Sharma), once sold second-hand clothes. Vendors may have other work and many see it as a temporary strategy. When people in the city are out of work or out of luck, they try to get money together to buy or split a bale of clothing and then sell it wherever they can.

When he started out Dipen mostly sold clothes to tribals. The tribal population of the city had grown following conflicts in the hills in 199os and as the population grew second-hand clothes markets began popping up. This reflected certain perceptions of the way tribals dressed - in Western clothes, their relative poverty - especially those who had fled to the city from violence in the hills, and their different (alleged) notions of cleanliness - which meant they accepted second-hand clothes. Meiteis, in contrast, were perceived as less interested in second-hand clothes for the inverse reasons; traditional clothes bought ready-made or tailor-made, ceremonies and rituals required purchase of new clothing, and second-hand clothes were seen as unhygienic. I was retold this same story several times from other vendors. Like many things in Imphal, the story was woven around the ways fundamental differences between tribal and Meitei communities are popularised. Yet what explains the softening of this divide? What explains second-hand clothing being sold across Imphal to and by members of all different ethnic communities? There are different answers. 
Image 5.2 Local clothes shop, New Checkon

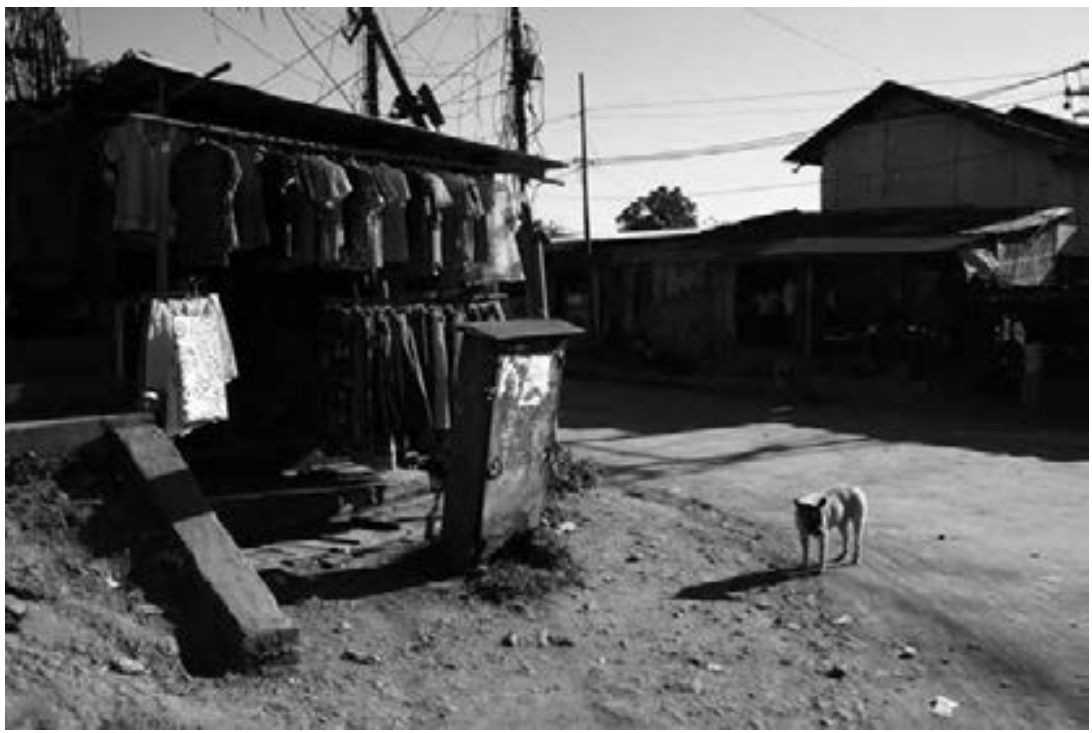

One evening sitting in Dipen's shop he gestured to a Meitei woman in a traditional phanek (sarong) and innphi (shawl) walking along with her daughter (presumably) who was wearing tight, yellow-coloured jeans and a bright red blouse with shoulder pads and matching red lipstick. Dipen gave a commentary as they browsed, positing that the contrast between the older and younger women illustrates a general turn away from traditional clothing, local versions of Indian clothing, the embrace of foreign fashion among the young, and perhaps most significantly, the rapidly accelerating cost of living.

I saw this in action one evening in Dipen's shop. We were eating some bora with a mutual friend who had introduced us, and a young woman dressed in a short skirt and T-shirt with a black-and-white motif on it came to the shop with two of her friends. She wanted a skirt. As there are no consistent sizes or labels on anything, Dipen passed her a tape measure to measure her waist right there on the road. Doing it himself would unsettle moral sensibilities. The woman called out the measurement and Dipen pulled out a pile of skirts of similar sizes and measured the waist to see what fit into her size. She chose a denim skirt that was too big, paid 70 rupees (\$1.20 USD), and took it across the road and into a lanewaylined with tailors - women and men - who sat in the open behind sewing machines.

It was part demand and part supply. Getting clothing was now very easy compared to the past. The bales weight 10okg and have 200 or so items 
inside. They usually contain one type of clothing, such as men's pants, or women's jackets. They also have an indication of the origin of the clothes, and the grade (A, B, C), which can also determine the price. Bales from the United States, Canada, and Korea fetch the highest prices, while those from other places (or bales with no place of origin) are sold for much less. From these 200 items, Dipen usually finds 30-40 good quality items. He sells the rest to mobile vendors or to vendors in smaller towns. Other vendors mentioned that as the cost of bales was going up rapidly, they needed to sell more to make a profit, so they sometimes held on to lower-quality items. Sometimes they doubled as mobile vendors, going to particular spots on Sundays or in the evenings to sell their lower-quality stock.

During my visit in mid-2013 Dipen had just received stock from Canada. The shipment had a lot of sportswear from high school and college teams. Dipen explained that these are popular because the synthetic material meant they dried faster in the wet season. He also had a lot of women's clothes that had come from Korea, mostly jeans and skirts. And business shirts for men, many of which were white, which he had trouble making look clean. His winter stock was different. Lots of used coats, mostly with Chinese and Korean labels. Like many vendors I met, Dipen liked bales from Korea best. The stock cleared quickly and it was usually clean and good quality. There was demand for things with Korean labels on them. It was common to see people walking around Imphal with T-shirts with Korean writing on them, coats with embodied labels on the corner, and, most popular of all, puffer vests, many of which had the names of Korean firms or of particular occupations, such as 'safety officer' and 'traffic control'. Many items from Korea don't have writing on them, but it is important for vendors to be able to show a label on the inside or some other proof of Korean origin to be able to charge more. The price for a bale of Korean clothes had nearly doubled in the last three years to almost 6o,0oo rupees (\$10oo USD) by 2013. The rising price of buying stock was a problem, but so too was the proliferation of those selling clothes and the stock of new clothes coming across the border. When I went back to see Dipen a year later, in mid-2014, he had given up second-hand clothes trading and sold new clothing from Moreh - the border with Myanmar. He was mostly selling jeans and T-shirts made in Thailand.

Indeed new clothes shops are becoming more common in Imphal, especially in malls and in 'showrooms' (stand-alone shops) - not just in the main bazaars but also in different localities. These come from Thailand and China across the border at Moreh but also from the garment factories of Myanmar and, in the case of factory seconds, from Bangladesh via the 
distribution markets and centres along the Siliguri corridor that connects the Northeast to the rest of India through a narrow tract of land. There are also global and Indian brand name stores opening in Imphal: Reebok, Levi's, and a Woodlands, to name a few. But these shops are very expensive. Still nothing compares to the tide of second-hand clothes that threatens to submerge pavements, public buildings, and any spaces left unattended.

Poor and middle-income urban dwellers utilise connectivity for livelihoods generated by the clothing demands of the cosmopolitan and fashionconscious population of Imphal. The constant flow of second-hand clothing into the city provides opportunities for mobile vendors, especially for women, many of whom are widows or have migrated from outside the city for work. However, in a city where control of space is enacted by state, non-state, and quasi-state actors, peddling second-hand clothes can be a hazardous livelihood strategy. During fieldwork I was introduced to mobile vendors by members of a local NGO, Women's Action for Development, and was also fortunate enough to have access to a survey they undertook with 200 mobile vendors. The survey, along with time spent observing the everyday lives of mobile vendors, linked connectivity 'from below' to poverty, to violence past and present, and to the dynamics of spatial control in the disturbed city.

The local police, licenced vendors, and selhunbi (a community moneylender) harass unlicensed vendors. Vendors repeatedly pay bribes to police and VDF to leave them alone or to recover seized stock. If they don't pay they can spend time in jail. The Manipur Government periodically launches drives to rid the pavements of vendors; an explicit part of their urban development strategy as discussed in chapter 2. 'Fake' self-help groups also prey upon vendors by setting up cooperatives to purchase licences or permanent places in a legal market and then disappearing with the contributions. Another scam reported when I was in Imphal in 2013 saw vendors being asked to provide information to a cooperative, the founders of which secured a grant from the government and then kept the money - paying off bureaucrats along the way. For vendors there are few ways of knowing who is legitimate and who is not. During the day plain-clothes men with no obvious authority ask for bribes from clothing vendors outside the Khawairamband Keitel, one of the new indoor markets in the centre of the city. They may be off-duty police, selhunbis, VDF, members of underground groups, or none of these. The ambiguity of authority poses dilemmas for those being solicited; it is almost impossible to know who can be challenged, who can be trusted, and who can be ignored. Dual connectivity floods the city with more goods to sell, yet selling them involves navigating the overlapping and often opaque micro-sites of power and attempts at spatial control. 
However, vendors keep coming into the streets everyday, transforming the urban landscape. In some locations vendors have managed to firm their claim to a spot in the city, creating a safe space for selling clothing and other goods. This may not always mean the place is legal, just that there is limited harassment. In some cases vendors end up occupying parts of the city. During the renovation of the Ima Keithel Market (mothers' market) in central Imphal during 2008-10, a temporary market was created across the road on the site of an old hospital that had been demolished. During the renovation licenced vendors from the Ima Keithel were permitted to trade there and moved back into the Ima Keithel when it was finished. Before the civilian authorities could reclaim the temporary site, unlicensed vendors occupied it. Four years later they remain.

Connectivity did not create vendors. Yet connectivity has meant there are more goods to peddle. At the same time migration to Imphal brings more people to the city from other parts of Manipur and other parts of the borderland seeking work. Some work in construction, some in sex work, some traffic narcotics, some start self-help groups, some sell vitamins door to door. Hundreds sell clothes. In the disturbed city where space is controlled by state, quasi-state, and non-state actors clothing vendors are the spatial rebels. They set up virtually anywhere, put up with almost anything, and transform patches of the city into impromptu markets. The constant demand shows the desire for fashion of a certain kind, with certain origins, and reflects a certain cosmopolitanism of the borderland.

\section{Closing the Gate}

Liberalising the frontier recalibrates Imphal from an isolated city - the end of the road - to a gateway city very much on the road. The road is the Asian Highway, a project with considerable history now under the stewardship of the United Nations Economic and Social Commission for Asia and the Pacific (UNESCAP, 2013). For India the highway aligns tidily with the Look East Policy and aspirations of NEV2020. It is the material manifestation of the Look East rhetoric. Connectivity along the highway is dual, and it is not only increasing flows of goods and people between the borderland and Southeast Asia but between the borderland and the rest of India. The implications for Imphal are considerable. On the one hand, increased flows of goods and people reduce dependency on the Indian Government. On the other hand, Asian connectivity is a state project where sovereign governments contribute infrastructure, goodwill, and symbolic gestures to 
boost economic growth. It locates Imphal firmly within India's territory, its gateway east: a possession on its frontier.

The ASEAN-India car rally was held for the first time in 2004 starting in Assam, travelling through Manipur to Myanmar, Thailand and through mainland Southeast Asia before reaching Indonesia. Atal Vajpayee, the former Prime Minister of India (1998-2004) and former Minister for External Affairs, proposed the rally. Vajpayee was a keen proponent of stronger connections between India and ASEAN members to improve economic prospects, to hedge Chinese influence, and to better secure the borderlands (Chatterjee, 2007; McDuie-Ra, 2009b; Yahya, 2003). Prior to the start of the first ASEANIndia rally a conference was held at the Indian Institute of Technology in Guwahati. At the conference the then Secretary General of ASEAN, Ong Keng Yong of Singapore, made a speech that exemplifies the notion of transforming the frontier through connectivity. During the speech he noted:

The North East Region with its abundant natural resources and strategic geographical location is certainly poised for economic development when the region is opened up and make accessible to the rest of the world ... [T] he First India-ASEAN Car Rally would open up the frontier and landlocked areas of India and ASEAN, linking our peoples at the common borders ... Transportation is vital to open up the geographical and mental space for economic growth ... [L]et me emphasise once again that the India-ASEAN Car Rally is not merely a social encounter between ASEAN and India but a trail-blazing beginning. Let's ensure that concrete steps are taken to forge greater cooperation for the development and prosperity of the peoples of India and ASEAN. (Yong in ASEAN, 2004)

Yong is clear that being landlocked is a hindrance, but also that opening the 'mental space' is necessary to realise the potential of borderlands in both India and ASEAN, reflecting a common refrain in India about the local obstacles to potential growth.

The rally did not take place again until 2012 when it was timed to coincide with the $20^{\text {th }}$ anniversary of the ASEAN-India dialogue partnership and began in Indonesia and ended in Guwahati in Assam, though it was officially 'waved off' in Delhi. At the ceremony in Delhi the then Prime Minister of India, Manmohan Singh gave a speech echoing that of Yong eight years earlier:

This rally symbolises the vision of an ASEAN-India community where people, goods, services and ideas can travel freely between us ... [O]ur 
future will be driven by the bonds of connectivity we build in the coming years. These physical bonds will be strengthened by digital links, which will help our younger generations to network better. Together, this web of linkages will help unleash the vast economic potential of our region, accelerate development and deepen our strategic partnership ... For India, nowhere will this benefit be more pronounced than in our Northeastern states and I would encourage the establishment of institutions linked to the India-ASEAN relationship in the Northeastern states ... While we flag down this Rally, we are also flagging off a new journey of closer cooperation and a deeper strategic partnership, not only for the benefit of our people, but also for peace, progress and prosperity in our region and the world. (Singh in ASEAN-India, 2012)

The rhetoric was virtually identical. I was in Imphal and later Guwahati during the car rally in December 2012 and can attest to the fanfare created for the arrival of the cars - each representing a different ASEAN country, plus India, along with support vehicles. The flags of ASEAN nations were erected along the highways in the cities. Bamboo gates were constructed on the roads for the cars to pass through adorned with the ASEAN-India slogan 'Progress and Prosperity' and the logos of the various event sponsors, mostly Indian firms and government ministries, as well as a Vietnamese steel and construction firm (Tón Hoa Sen). Locals lined the highway at different points to watch the cars pass through and catch a glimpse of the future. The rally passed through Imphal where the Chief Minister of Manipur, Ibobi Singh, waved off the cars from Kangla Fort under heavy security. Ibobi echoed the Prime Minister and spoke of the strategic location of Manipur as a gateway city to India and to Southeast Asia for transnational connections by road and potentially by air and rail, before a Manipur cultural dance troupe took over the proceedings.

In Guwahati the cars entered the National Games stadium on the outskirts of the city where, following more speeches about the future prosperity of transnational connectivity, the crowd watched cultural displays, daredevil motorbike stunts, an Air Force show, and various flag-waving exploits reminiscent of a closing ceremony of a major sporting event. The display was very state-centric - sovereign national territories celebrating 'potential' and the transformation (or potential transformation) of the frontier into a corridor. The symbolism of the rally drew the borderland into international diplomacy as a constituent chunk of sovereign India and its gateway. The borderland could share in the potential of eastward connectivity but only when participating in a larger project with two parts; enclosing the borderland within India's sovereign territory and benefitting 
from the relationships that India forms with other sovereign territorial units and their associations. An interesting side note to this is that in 2013 an ASEAN-India Centre was opened in India to fuel the ASEAN-India partnership. The centre is located in Delhi at the Research and Information System for Developing Countries, a think tank under the Ministry of External Affairs, suggesting the future trajectory of official connectivity will be decided a long way from the borderland.

The ASEAN-India rally in 2012 had a happy ending; India's control of the territory it claims was demonstrated. The cars passed through unharmed. The Manipur Government played along, willingly given the potential benefits of connectivity, and non-state actors with the power to disrupt resisted doing so. But only just. In the days leading up to the rally passing through the international border at Moreh and onto Imphal, activists demanding a Kuki state threatened to prevent the rally from passing along National Highway 39, also refereed to on more optimistic maps as Asian Highway 1. The Kuki State Demand Committee (KSDC), an unarmed Kuki organisation formed in 2010 to pursue a separate federal state for Kuki communities carved out of the present boundaries of Manipur, pledged to block the rally before it could reach Imphal. There are 15 or so armed groups representing different Kuki groups alongside several 'aboveground' groups like the KSDC (Thangboi Zou, 2012). Members of the KSDC gave a press conference in Churachandpur - the largest Kuki town in Manipur - on December 11, just four days before the rally was due to cross the international border, stating that not a single vehicle would pass through Kuki territory. As the Sadar Hills blockade a year earlier held for over three months, this was a pledge to be taken seriously. The Sadar Hills movement discussed in chapter 4 called for upgrading the status of the district, whereas the proposal in late 2012 was to revisit the idea of a fully-fledged Kukiland state carved out of Manipur. As reported in the daily newspaper Hueiyen Lanpao, members of the KSDC stated:

We are aware that this rally was proposed by the Indian Prime Minister to strengthen India's economic ties with ASEAN. However, we feel such ties are hollow and at best exploitative of our rights on our territories and our rights to develop as a people are denied and [not] give[n] proper recognition. We shall have no obligation to uphold India's commitments and honour unless the issues of our land rights are settled to our satisfaction. We stand firm on our resolution to launch 'quit Kuki land' against the Indian government if our politically humble appeal to have our rights recognised in the Constitution of India is treated with disdain. (Hueiyen News Service, 2012) 
Earlier in December a map was released to the press with the proposed Kuki homeland shaded green. The green areas encircled the Meitei areas in the valley and left the other hill communities with lands in the north of the state. The map caused consternation among communities in the valley and among other hill communities, especially Nagas. The threat to launch a 'quit Kuki land' campaign stirred memories of the violence between Naga and Kuki communities in the 1990s, wherein members of both communities were involved in violence to render territories ethnically exclusive (Oinam, 2003; Tohring, 2010). Naga organisations such as the United Naga Council welcomed the car rally to counter the Kuki position and encouraged Nagas to welcome the cars as they passed through 'Naga areas' (Times of India, 2012).

The threat of blockade was taken seriously. Residents began stockpiling supplies of food and fuel, prices in the market rose quickly, and politicians called for calm. During the days between this statement and the arrival of the rally cars I experienced a very odd ethnographic moment. I still cannot determine whether the circumstances were purely by chance or by design. A friend and journalist, Yangnu, had arranged to meet me in the restaurant of an Imphal hotel where I was staying. The hotel lobby was crowded with armed men from various Manipur security forces and some paramilitary troops guarding the entrance. This is not uncommon in Imphal as hotels are often where politicians and other VIPs hold meetings. As I entered the lobby from the stairwell I didn't pass through the security and I slipped into the restaurant and waited for my friend. In a small alcove in the corner of the restaurant - a spot shielded from the lobby - were three men from the hills dressed in very typical clothes for well-educated men of their age; suits, woollen sweaters and ties. The restaurant was otherwise empty. I saw Yangnu talking her way through the security in the lobby and pointing at me through the glass doors. She sat down at the table and motioned that we should sit silently.

Several minutes later a very senior member of the Assam Rifles in uniform entered the restaurant with his assistant and sat down with the three men. They greeted each other respectfully, shaking hands and enquiring with each other about the journey to Imphal before ordering tea. The common language between the men was English given the men from the hills did not speak Hindi and the paramilitary officials (presumably) did not speak the relevant local language. The party began to discuss the blockade of the ASEAN car rally. On cue the staff in the restaurant increased the volume of the background music. The music played was the hit songs of Bryan Adams - a favourite in the Northeast along with ABBA and Boney M. As the Canadian crooner sing 'All for Love' the suspension of the blockade was negotiated. We took this as our cue to leave a place where we probably should not have been in the first place. 
Once out on the street my friend was bursting with energy, 'See, see! The real politics happens with the paramilitary. Not the government. It's good you saw that.' I never found out exactly who was in that room and we didn't discuss the incident until Yangnu telephoned me the next day to tell me to look at the newspapers. The blockade was cancelled with the press reporting that the Indian Government had promised the KSDC and other groups a high-level dialogue by February 2013. (As it happens, the dialogue failed to take place, leading to further blockades. However, the rally was saved.)

At first glance the position of the KSDC challenges territorial claims over Kuki lands by India and by the federal state of Manipur. The politics appear to be a display Manipur's hill versus valley politics with the Indian Government being used as leverage - and a target for activism given the power of the Indian state to grant the territorial status desired by the KSDC. Yet the claims are also about the territorial politics between hill communities as discussed in chapter 4 , and about control of the lucrative informal taxation of vehicles on the Imphal-Moreh highway. Given the stakes, mostly symbolic, of eastward connectivity for the transformation of frontier to corridor, the power of local groups to cut off connectivity gains new significance; the scale jumps. Eastward connectivity makes this stretch of road a new artery of vulnerability for India, a new opportunity for leverage with the state, and for making political statements 'from below'. In other words, if Kuki activists were just blocking off Moreh from Imphal the issue would be localised; yet blocking off Indian from Southeast Asia heightens the scale of the territorial claim and highlights the fragmented nature of sovereignty in the borderland.

For Imphal as a city, eastward connectivity puts the city on the road to Singapore, to Bangkok, to Kuala Lumpur. Faraway places that figure prominently in local aspirations for a better life. Even Mandalay in Myanmar is mentioned as a destination for direct buses and international flights from Imphal - a place to go and just be somewhere else, somewhere better (regardless of the reality). The ASEAN-India car rally brought these places to the city in brightly painted cars plastered with national flags and sponsor logos, suggesting a connected future. Imphal may be on the road to somewhere but the road crosses lands subject to multiple claims. The higher the stakes in this future, especially when the Indian state is involved, the more valuable the route becomes for communities seeking to make claims on territory, for autonomy, against authorities, or to just get a seat at a table where the rearrangements of territory will be discussed; as was the case with the KSDC in 2012. Being able to control the gateway city, to shut the gate, as it were, enabled the KSDC to bargain with the state, though in the 
end the negotiating was done with the armed forces demonstrating the fragmented sovereignty of the disturbed city.

\section{Conclusion}

India's liberalisation has been analysed at length from virtually every disciplinary angle. The concept of new India as a political, social, and economic entity distinct from earlier versions of state and nation - and the limitations of this idea - are central to this analysis. Regardless of one's position on the extent to which new India is identifiable and replaces a cogent old India, one must recognise the ascendency of liberalisation is an eminent ideology - whether endorsed or opposed - in national and subnational policymaking as well as in visions about the future of India. Attention to neoliberalism in the borderland has been limited owing to the dominance of security and state-led development in its governance. Neoliberalism is harder to see with such an overwhelming state presence. Rhetoric about looking east and acting east has been around for decades in both Delhi and the Northeast states (Haokip, 2015). Connectivity has slowly been implemented through symbolic gestures such as the India-ASEAN car rally and material changes such as the opening of the land border with Myanmar and the arrival of national and international capital and its trappings - billboards, advertisements, and consumer goods. The recalibration of Imphal from a frontier city to a gateway city is central to this project. However, the disturbed city is an atypical space for the market to penetrate.

This chapter has explored the liberalisation of this sensitive space - a space where the decline of the state takes on new meaning in a polity where state control is partial to begin with; where old India has been strongly resisted. Through the examples of the campaign for Meitei Mayek script on all public signage to mark capital with a statement of sovereignty, the clothing trade as a way of utilising connectivity to make do and rebel against attempts at spatial control, and the attempts to block the ASEAN-India car rally exposing the heightened scale of vulnerability for India, I have explored the local practices that reshape connectivity amidst the politics of belonging, control, and exclusion established in part one. The following chapter takes this notion of liberalising the frontier further by looking at the endogenous liberalisation of the health sector and the creation of a 'health city' - a hub for world-class healthcare from surrounding borderland polities on the outskirts of dysfunctional Imphal where struggles for electricity, water provision, and sanitation characterise everyday life. 


\section{$6 \quad$ Health City}

In 2012 I stood on the fourth floor of the Shija Private Hospital in Langol Lamkahi. On the other side of the road running past the hospital and all the way along the foothills to the National Games Village - completed to house athletes for the 1999 event and then sold off, in controversial fashion, in the years following - is a church built on a hillock, a cluster of houses on various flattened patches of hill, and at street level a row of restaurants and small hotels. A small sign marking the start of the 'reserved forest' is lost among the advertisements for Palmei Fooding and Lodging, Triune Medicos, and scores of small signs advertising various training courses and tutors to help students pass medical examinations. As I stared out the window a bus full of young women in yellow and purple nursing uniforms passed on its way to the hospital's own nursing college. At night, while much of Imphal is in darkness and the hills of Langol are speckled with small house lights, Shija glows from the lights generated by its own power supply. The site has been dubbed 'Health City'; a phrase that even the Chief Minister has begun to use.

The domed main building stands out in the landscape of Langol - its reflective glass visible against the backdrop of the hills. Branching out from the main building are a series of single-storey clinics and specialist centres, offering everything from obstetrics, to cosmetic surgery (specialising in rhinoplasty and blepharoplasty), to cardiology. Along the walkway connecting these clinics is a huge board listing the names of all the doctors who practice in these clinics, and in the wards and their hours. Almost all of them are from Manipur. This is significant given the brain drain out of the region usually creates the opposite scenario.

Part of the car park is given over to the hospital's own ambulance service. At the rear of the compound is a new blood bank and transfusion centre funded through MDONER and the NEC, the Indian Government's special ministry and coordinating agency to orchestrate development of the region. The blood bank is the only one of its kind in the borderland. In mid-2013, on one of many visits to Shija, I toured the blood bank with the hospital's public relations officer. I was telling him how impressed I was by the technology on display in the facility. He mentioned that the blood supply to Shija from the public hospital was unreliable, so they needed to secure their own supply. He paused and said, 'We need a reliable supply of blood because a lot of people get shot here'.

This chapter is concerned with the endogenous liberalisation of the health sector in Imphal. The boom in private healthcare has been dubbed 'health 
city', referring to the concentration of high-quality private health facilities in the city. This poses an obvious and somewhat compelling question: What explains world-class health facilities in such a tumultuous polity? The dire condition of the public sector, Manipur's high number of health professionals, the availability of (once) cheap land on the outskirts of the city, and the injection of capital from so-called silent partners all play their part. Demand from patients in Myanmar and other parts of the borderland is also a factor. This has produced alternative ways of enabling movement mobility across the border for patients that bypass Indian authorities. However, the private health sector is also an expression of self-sufficiency, of what can be achieved independently of the Indian state and the civilian government in Manipur. For a polity where the desire to reinstate sovereignty lost in 1949 has been a power determinant of the present conjuncture, the private health sector is a model of what can be achieved if the people of Manipur are left to their own devices. In a context where state-led development reflects neo-colonial occupation, self-sufficiency is a powerful symbol of both lost autonomy and future capacity - yet future capacity is almost always imagined as an autonomous state. Imphal's booming health sector is private by necessity, not desire. The boom in private healthcare has also transformed the landscape on the northwestern edge of the city created new battles over land between settlers who moved into the peri-urban fringe in the 199os escaping conflict and a new class of medical and other professionals seeking land and entrepreneurs seeking to build new facilities.

I begin with a discussion of health liberalisation in India and an account of a different path to liberalisation in Imphal. The second section focuses on the decaying public system and the emergence of an irresistible narrative about the benefits of the private health system; narratives supported by the quality of the facilities, care, and treatment experienced by patients. The third section returns to the puzzle of a world-class transnational health hub in the disturbed city. I argue that the health sector reflects a pragmatic response to state dysfunction and a kind of accidental liberalisation particular to Imphal. The chapter closes with an account of the ways the health city has pushed the boundaries of Imphal to the northwest, transforming the previously ambiguous zone around Langol into legible urban space.

\section{Building a Health City}

Throughout India there have been major changes to the provision of healthcare following liberalisation in the 1990s. As Selvaraj and Karan demonstrate 
(2009), health insecurity has increased in India since liberalisation in the wake of escalating healthcare costs for inpatients and outpatients, user fees for public facilities, patients being asked to procure their own medicines, the ascendency of the private sector in medical education, and in the training retention of personnel, and a growing urban-rural divide in access to healthcare. This increases the costs of healthcare on patients and their family members, increases household debt, and influences decisions on whether to seek treatment in the first place. The Indian Government has responded with various measures, including a health insurance scheme targeting families below the poverty line, the Rashtriya Swasthya Bima Yojana (RSBY) launched in 2008, and the National Rural Health Mission, launched in 2005, that increases availability of essential healthcare in rural and remote areas. Critics argue that these schemes further enable liberalisation of the health sector as they push patients towards private health providers without significantly reducing financial risk for the poor (Selvaraj and Karan, 2012; Vellakkal and Ebrahim, 2013). In a study of RSBY in the state of Maharashtra, Ghosh (2014) critiques the role of commercial insurance companies suggesting they are ill suited and uninterested in advocating for uptake of the scheme. Parallel research into the National Rural Health Mission suggests that it has fallen short of its targets but that it has put accessible public health and health equity on the political agenda (Balarajan et al., 2011; Husain, 2011). Exploring the diverse and often contradictory findings from this research is beyond the scope of this chapter; the point here is that in the broader narrative of 'new' India, health is perceived as an opportunity to improve efficiency and delivery by proponents of liberalisation, and an example of both the weakening of the state and the capacity of the state to enable further expansion of the private sector.

The borderland has been specifically targeted for improved health provision. Manipur and other Northeast states were identified as 'focus states' by the National Rural Health Mission, entitling them to higher per capita funding through the scheme. Manipur has many positive health indicators. It has one of the lowest infant mortality rates in India at 30 deaths per 1000 live births, which is significantly lower than the national average of 57 deaths (MHFW, 2009: 12). A total of $87 \%$ of women receive antenatal care, $83 \%$ from a doctor (MHFW, 2009: 12). Child nutrition indicators are also strong. Only $23.8 \%$ of the population under three years old is reported to be underweight, which is less than half the national average (45.9\%) and among the top three in India (Planning Commission India, 2007: 157). On the flip side the HIV/AIDS rate is estimated to be the highest in India (MHFW, 2009: 
23), tuberculosis rates are the second highest in India (MHFW, 2009: 24), and levels of sexual and physical violence are among the highest in India (MHFW, 2009: 28; see also McDuie-Ra, 2012c). Manipur's health sector is characterised by low uptake of funds. This can be seen in the gap between funds allocated and actual expenditure on public health (Berman and Ahuja, 2008: 213). Where these funds go is unclear, yet given the extent of corruption and the opaque nature of governance it can be assumed that they are absorbed at various points along the way. Annual regional health reports by the National Rural Health Mission note chronic shortages of staff in the hill areas - especially Tamenglong, Ukhrul and Chandel - though the situation is better in the regional towns in the valley, where there is a surplus of staff in certain health fields (NRHM, 2010; 2011; 2012).

The health scenario in Imphal is almost the reverse of areas outside the capital. There are five comprehensive hospitals (two public and three private) as well as scores of clinics, many advertising themselves as hospitals, specialist centres and diagnostic centres. Of these, Shija Hospital in the north of Imphal embodies the endogenous and pragmatic liberalisation of the health sector, and has extended the boundaries of Imphal. And it is at Shija where the juxtaposition between the health city and the disturbed city is most profoundly felt.

My meeting with Dr Singh, one of the founders of Shija Hospital, in mid2013 began with mutual recognition. I worked out we had met before in early 2011 at a cultural show at the Manipur Rifles Banquet Hall, one of the few sites for evening entertainment prior to the building of the Manipur Film Development Corporation auditorium, where I was the guest of Manipur University. On that night I had recognised him from a newspaper feature on keyhole surgery and we had posed for a photograph together. He remembered the photo and this helped ease the formalities somewhat. Needless to say, he is a prominent figure in the city.

Dr Singh came to our meeting wearing a long white coat and a stethoscope. His wife and son, also doctors, came and joined us at various intervals, but both were called away for urgent matters throughout. In 1996 Dr Singh and his wife resigned from the Regional Institute of Medical Sciences (RIMS), the main public hospital in Imphal, and started a clinic at the present site in Langol. At the time the forest was being cleared by the government to build the National Games Village, and settlers from the hills, many fleeing conflicts between Naga and Kuki communities had begun to build houses and churches in patches of cleared forest. Land was cheap, so they started a clinic, which became a hospital, which became the proposed 'health city' that now employs over 600 people. Dr Singh spent time in our interview 
Image 6.1 Shija Hospital, Langol

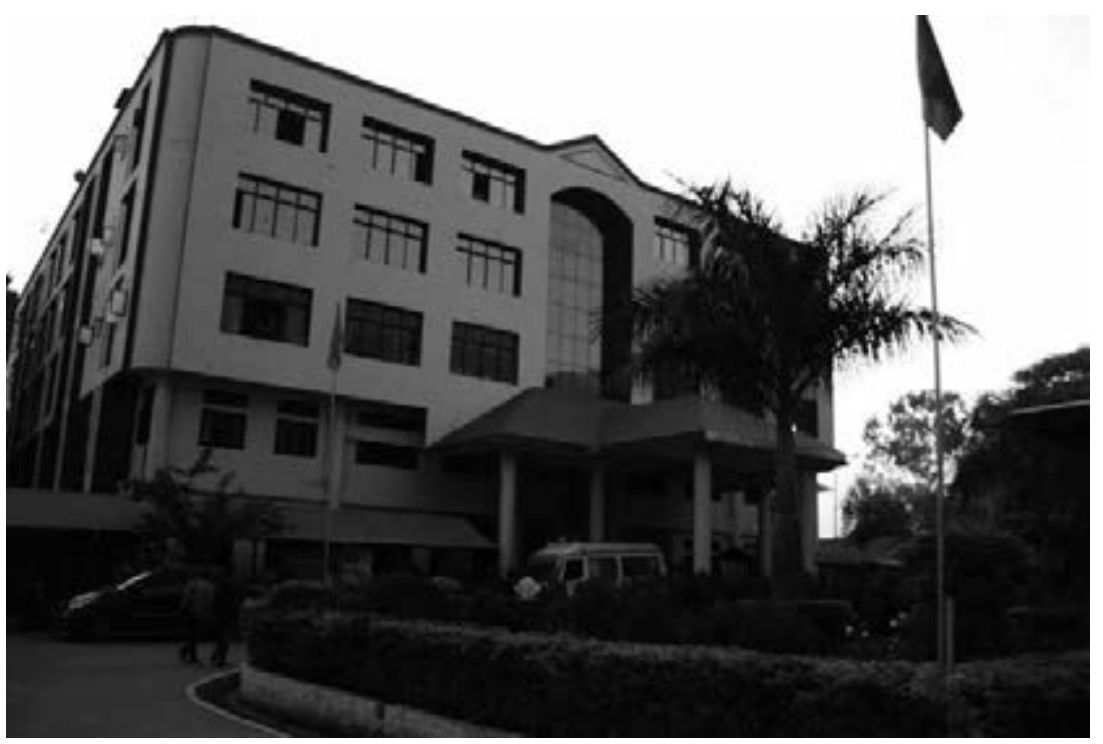

detailing the early days: terrible roads, no electricity, few patients, fear of ghosts, and scorn from other doctors about going private. Yet he was adamant that it was necessary. The public system was so bad that he had to start a private clinic to provide care to more people and try to keep medical professionals in the state. It was 'enforced'.

We spent a lot of time talking about specific medical achievements. Many of which are very impressive, especially given that high-tech medical breakthroughs are not expected to be found in the far-off, conflict-torn frontier. With limited medical expertise I soon lost track of all the specifics. I started to ask about the patients, where they came from, the treatment they were seeking, and their costs. The hospital received patients from the city and from all over Manipur, especially given the poor health facilities outside the city. There are also large numbers of patients from the neighbouring federal states of Nagaland and Mizoram, and from across the border with Myanmar. Dr Singh claimed that Shija is already the best hospital for people living in western Myanmar, particularly the Sagaing Division and Chin State that share a border Manipur. On my visits to the wards I have seen whiteboards listing patient's hometown as Tamu, the town on the Myanmar side of the international border at Moreh. There are official cross-border medical exchanges. Doctors from Shija run health camps in Monywa, a town over 300 kilometres from the border. Shija undertook a 'Smile Train' 
mission; a travelling entourage of surgeons doing free cleft palate operations in western Myanmar. Government officials from Sagaing Division have visited Shija and have talked about building a Myanmar lodge for patients. Medical tourism is the next step.

What is striking about this are the positions being performed. The doctors from Manipur, the borderland's dysfunctional state and India's turbulent frontier, perform the role of technologically advanced donors extending medical care to a (perceived) disadvantaged population across the border. Part of this outreach is also publicising the hospital in Myanmar and trying to push for easier access of patients wanting to cross the border. Dr Singh is pushing the Indian and Manipur governments for a visa-on-arrival system for patients from Myanmar, even if they don't have a passport. For him this was what the Look East Policy meant. The only thing Manipur has that they don't have across the border is well-trained medical professionals and medical technology. Connectivity would enable a regional medical hub to grow.

This is unlikely to be granted soon, at least by the Indian Government, given its concerns about uncontrolled movement back and forth across the border. In the meantime, the hospital circumvents state notions of sovereignty and territorial control. Dr Singh passed me onto another staff member to discuss this. In an administration office I was shown a sheet of paper with eight passport photos of patients from Myanmar glued on beside their names, hometowns, and ailments. A bus crosses the border and collects the patients - usually 40-50 patients at one time. Sheets of paper like the one I was shown are presented at the border, the names of patients listed, and when the patients leave back through the border these are checked off. This agreement is reached with the district police, rather than the Indian border authorities. In this way Indian sovereign control over territory and the border is circumvented by local agreements, by local regimes of connected actors that facilitate mobility and show alternative ways of controlling movement across territory. Look East may be a Delhibased imaginary, but it is enacted, and subverted in a variety of localised forms.

Shija's slogan is 'Towards Changing the Health Landscape of Southeast Asia'. It appears on their promotional material and on billboards in different parts of the city and in other parts of the borderland. This is a fairly significant statement. The hospital makes no attempt to locate itself within India. It re-places itself, and to some extent Manipur, within Southeast Asia or at least at its doorstep. Not only that, the hospital directors see a catalytic role for Shija in improving healthcare in Southeast Asia. This is certainly 
a marketing strategy, however, it is drastically different to the kinds of corporate language that is usually transmitted in the borderland which focuses on the place of the borderland within India, usually at a later phase of development, suggesting the borderland lags behind the rest of India; goods, brands, and technology take time to arrive ('Now in the Northeast' etc.). Their arrival is a reminder of both the distance from the heartland and the place of the borderland within the nation. Shija's slogan doesn't bother with the nation at all.

It is not just doctors and patients that cross borders. Blood, stool samples, tissue samples, $x$-rays, all flow within and outside Imphal. The Babina Diagnostic Clinic, founded and run by another doctor-turned-healthentrepreneur, Dr Thongjam, is instrumental in the mobility of bodily samples and images. Like many doctors of his generation, Dr Thongjam studied outside the state and was warned against returning when Manipur began to unravel in the 1980 . He started a small diagnostic clinic in 1983 with a rented microscope and now has 60 collection centres throughout the borderland and one unofficial centre across the border in Myanmar. While touring the labs with Dr Thongjam he gave me a rundown of the different equipment, what it does, and where it came from; Germany, Japan, Korea. He made a point of introducing me to the technicians, who talked about where they had trained and why they had come back to live in Manipur; stories I knew well from my previous work on Northeast migrants. The main diagnostic centre is in Imphal at Soibam Leikai, but there are others in Nagaland, Meghalaya, and Assam. Through this network they claim to see 1000 patients a day and then refer them on to other doctors. Anything that can't be tested in the regional centres comes to Imphal. Samples are sent throughout the borderland and in and out of Myanmar in thermal boxes using their own fleet of vehicles. During the blockades of the city discussed in chapter 3 , blood and other human samples tended to be allowed through, though not without complications from time to time.

The missing element is oncology, but Dr Thongjam plans to have this up and running in the next few years. Patients seeking treatment for cancer have to travel outside the state, at great expense, to Guwahati, in neighbouring Assam, where some forms of cancer can be treated, and to Chennai, Delhi, Kolkata, and Mumbai. In these locations there are agents whose main business is assisting patients from the borderland in getting care by translating, arranging accommodation for relatives, and helping patients get admitted to hospitals. These agents add further costs that put treatment well beyond the means of many. 


\section{The Decaying Public System}

There are other private hospitals and clinics in Imphal, including specialist maternity and paediatrics hospitals (Maipakpi and Leirik Memorial) and a few scaled-down versions of Shija, such as Imphal Hospital (which seems to catch a lot of overflow from those tired of waiting at the nearby public hospital) and City Hospital and Research Centre at Chingmeirong. Yet Shija is the most comprehensive hospital, research, and training facility and provides the most compelling contrast to the two main public hospitals, the Regional Institute of Medical Sciences (RIMS) and the Jawaharlal Nehru Institute of Medical Sciences (JNIMS).

The public hospitals face a number of challenges. Conversations with two senior surgeons from RIMS and with doctors who have left the public sector reveal the depths of these challenges. RIMS was once the leading hospital in the borderland, but now the facilities and technology are dated and much of the infrastructure is badly damaged by neglect and unfinished reconstruction. The site feels like a caricature of failed development: the campus has piles of rubbish, cows roaming around, broken windows here and there, and peeling paint. Corruption continually comes up in conversations about the condition of public hospitals, seemingly offering a ready-made explanation for the difference between the public and private facilities. RIMS is still a major teaching hospital, given the demand for medical training in Manipur, but competition from private training and from places like Shija and from colleges outside the state have altered the calibre of students studying at RIMS. Those who can afford to study elsewhere do.

JNIMS, at Porompat in the city's east, is in slightly better shape after undergoing upgrades in 2012 and 2013, though the facilities are nothing like those at some of the private hospitals. From time spent in conversation in the waiting areas and from friends in Imphal who have experience of the hospital, it appears that connections are required to get an appointment, especially for outpatients. I was interested in why doctors continued to work in the public hospitals when they could earn more money in private hospitals or outside the state. I was told repeatedly that doctors see patients at the hospital for initial consultations and then encourage them to visit them at private clinics or the private hospitals, where the equipment and facilities are better and where they can charge higher fees. In fact, so common has this practice become that many patients begin seeking treatment at JNIMS with the intention to then continue treatment elsewhere. Just outside the western entrance to JNIMS there is a cluster of private clinics and 'hospitals' within a few feet of the hospital walls. There are also enormous billboards 
for the larger private hospitals listing their services and achievements. The message is clear; the best care is in the private sector and those entering the public hospital have this message confront them upon entry. Obviously this has major consequences for the kinds of care available to those who cannot afford to shift to the private sector.

\section{Accidental Liberalisation?}

The private health sector in Imphal is apparently booming. This poses a very peculiar puzzle. How is this possible? Imphal struggles with electricity, water supply, and waste disposal. Corruption flourishes in all virtually all aspects of life. Violence is routine and prolific. How has this city become transnational health hub?

Respondents in the health sector explain that the public health system was so bad that health professionals were forced to start their own facilities and patients were willing to pay for healthcare to avoid the public system. For health professionals there are several components. The private sector provides more career advancement and professional development opportunities, even simply through access to new machinery. This is difficult in the public system given the levels of corruption and the very conservative hierarchy. With few opportunities to break through this many health professionals left the state in the past to pursue careers outside the country. The private health sector is seen as a meritocracy compared to the bureaucratic, rotting, and corrupt public sector. While there are no doubt noble intentions among health professionals to improve the standard of care, there are also many more opportunities to increase earnings in the private sector. For health entrepreneurs it is also easy to expand in the private sector, adding more staff, specialists, acquiring more equipment, and, in some cases, land. This is much slower in the public system.

For patients, the standard of care is better, admission is faster, the equipment is more advanced, and the medicines are unlikely to be fake. Whether or not there is an enormous difference across all the forms of care is debatable, however, the perception is that private is better. Some of the private hospitals offer their own reduced fees or free care for poor patients (though it was difficult to gain concrete information on how this worked). Revenue from specialist and elective treatment was said to be used to cross-subsidise primary healthcare. Public money is used to subsidise costs for patients in the private sector, too, though not for all patients. This scenario also means that funds dedicated to healthcare, whether from central or federal state 
pots, are spent on subsidising care in private facilities, presumably leaving less for building similar facilities elsewhere, especially outside Imphal.

The longer one engages in these conversations the more familiar they sound; the private sector is more efficient, more merit based, and a panacea for corruption and public dysfunction. It is the same kind of argument that one hears from free-market proponents throughout India. Yet in Imphal the emergence of the private health sector appears less of a calculated strategy than a kind of accidental liberalisation: a pragmatic response to state dysfunction and neglect. Though, if the private health sector began as pragmatism to deal with state absence, it has gathered state support. For instance, Shija Hospital has received funds from the Delhi-based MDONER and NEC, and the Manipur Government (though this level of support came only after the hospital was established). Several state organisations also empanel it, meaning that patients employed by certain state agencies or under certain eligible schemes, including RSBY (the health insurance scheme for the poor) in Manipur, have the cost of their treatment subsidised. The telling inclusions in Shija's empanelled list are the governments of neighbouring federal states Mizoram and Nagaland. Government employees and those eligible for health subsidies can receive treatment at Shija rather than in their own states, contributing to the hub.

The notion of the private health sector as an enforced split from the corrupt public system is interesting for other reasons. Virtually all business in Imphal requires connections into the murky world of elites: conventional political and business elites are part of networks with figures of traditional authority, high-ranking members of the military and security establishment, and leaders of underground and ethno-nationalist groups. Rumour about silent partners affiliated with the murky world abound. One always has to be careful with this kind of information in Imphal. With such opaque structures of power it is very difficult to prove any rumours and perhaps that is beside the point. Social life thrives on speculation about who is connected to whom, on who really funded what, and who protects whom. The point to be made here is that adage that the private health sector in Imphal is clean, modern, and corruption-free when compared to the dirty, dated, and corrupt public health sector requires some nuance. Partners and protection are vital for any enterprise in the disturbed city. The triumph of the invisible hand of the market is a possible reading from a distance, but not on the ground.

A second explanation for the emergence of the hub in Imphal is human capital. Studying medicine and nursing have long been ideal pathways for young people in Manipur who want to get ahead. As one doctor told me, 
studying medicine is to Manipur what studying engineering is to India. Imphal has countless tuition schools and private tutors that assist students in completing examinations to gain entry into medical training. Data from the National Rural Health Mission shows that Manipur actually has a surplus of qualified medical workers. There are almost double the required number of doctors in primary health facilities, double the required number of female health workers/assistants, as well as surplus pharmacists and technicians (NRHM, 2014). Each year vast numbers of students migrate outside the state to undertake medical training, often at great expense to their families. I encountered many of these migrants during my previous work on Northeast migrants in Delhi. Migrants don't just head for metropolitan cities, but to medical colleges throughout India and beyond (McDuie-Ra, 2012a: 62-63). During a visit to Imphal in mid-2014, I saw a sign outside a travel agency cum education centre that read 'MBBS in China and Ukraine', indicating how far people in the state will go (or at least how far travel agents think they will go). Nursing is similarly popular among women in Manipur (the profession is still heavily gendered in India). Imphal hosts a number of public and private nurse training institutes. There is also migration to train outside the borderland, especially in south India. The market for medical and nursing students from Manipur is becoming well known in other parts of India and recruitment of students for training outside the state is a big business that will be discussed in the following chapter. With chronic under- and unemployment and a disrupted economy, in combination with high education and literacy levels (at least when compared to Indian national averages [McDuie-Ra, 2013: 80-81]), and a growing remittance economy, medicine and nursing are seen as crucial for the livelihood chances of young people and their families. Even the Directorate of Health Services has an imprecise view of the state's nursing numbers, reporting that Manipur 'is one of the biggest producers of nurses per capita probably highest after Kerala. The people of the state in general have no prejudice towards the nursing profession. The nurses are trained at various institutions outside and inside the State. There is glut of nurses in the state and many are employed outside the state' (2014: n.p.).

There is a large pool of human capital available to the private health sector. Health entrepreneurs can target Manipuri medical professionals and offer them careers back home; something that the public sector was increasingly unable to provide as doctors could make more money elsewhere and advance their careers. This is changing. Further, the desire for families to send their children to medical and nursing colleges means that private hospitals can offer training at home, for a lower cost than sending 
children outside, and use this to expand their own operations. There is still high demand to train and work outside, but there are more and more health professionals coming back. As one doctor told me, 'Once when you finished training they said "go west". Now you can say, "I want to go east" and people accept it'.

A third explanation is greater mobility enabled by connectivity. Imphal is a health hub because more people can get to it. The opening of the border plays a large part in this, though as seen above, even this requires some creative border practices to get patients flowing into Imphal's hospitals. Further, health seekers from Nagaland and Mizoram, as well as other districts in Manipur, have enhanced the sector in Imphal; there are more patients, and more supplementary livelihoods serving their needs in guesthouses, transport, and food. Imphal is not exactly the geographic centre of the borderland, but as it sits in a valley surrounded by hills in all directions it does have a kind of natural pull for people living in those hills.

\section{Reshaping the Urban Frontier}

The booming private health industry has reshaped the urban landscape. As older planned institutions, RIMS and JNIMS have large campuses. Given the shortage of space in the city, new facilities appear to burst out of the blocks they are built on, with few ways to access the buildings, nowhere to drop off patients, receive ambulances or dispose of hazardous waste. In contrast, the two most well-known private facilities have played a major role in reshaping urban space in their vicinity. Babina Diagnostics' current centre is built on top of a marsh in Soibam Leikai. The land was too unstable for building so remained as a wasteland and a site where neighbourhood residents carried out small-scale aquaculture. Building on this kind of land requires soil and rock, and most of that must come from the hill areas of the state and the foothills around Langol; a common cause of landslides and further fuel to the grievances of the valley inhabitants. Once the ground was stabilised, the four-storey facility was built in 18 months. The public access road was too narrow, so the diagnostic centre paid to widen and resurface the road. They maintain it and keep the area around the centre clean. This small patch of the city is almost entirely privately run. Other similar businesses have opened in the vicinity. Small operators selling medical supplies, equipment, pharmaceuticals, and smaller diagnostic clinics line the road that connects Soibam Leikai to JNIMS. As mentioned above, the area outside JNIMS is home to a number of smaller private clinics clustered around the gate. 
Neighbourhoods exist behind the rows of multi-storey buildings along the roadway, but rapid construction, increased traffic and noise, and water insecurity from the disappearance of community pukhris and ising kongs (drainage channels), combined with higher land value, has meant many residents have sold land or leased their land and gone to live elsewhere.

Langol is an area on the northern fringe of Imphal where the foothills begin to rise out of the valley and the jurisdictional boundaries between Imphal West District and Senapati District are blurred. It is an important division as it signifies where the different land use regimes of the valley and the hills begin and end. Langol was long believed to be a wild landscape: an ambiguous zone that is neither hill nor valley, neither Imphal municipality (a nominally Meitei space) nor Senapati District (a nominally tribal space). It is the frontier of the frontier city. Since 1938, 22 square kilometres of Langol have been designated 'reserved forest'. Older residents of Imphal remember Langol as a place of plant and animal life. The steep foothills, thick trees, and swampy group made it very difficult to build houses here. Langol was occupied by bad spirits; a place for cremations for bodies that can't be cremated in city localities - usually if the cause of death is suicide - and a place where bodies killed by security forces and underground groups were dumped so they wouldn't be found. During fieldwork I was drawn to Langol like no other part of the city.

The journey into Langol begins on Thangmeiband Road, which skirts the base of the foothills from Yumnan Leikai, near the new state assembly building, northwest to join Langol Road, which continues in an arch, still along the base of the foothills past Shija Hospital and onto the Games Village before passing the Central Agricultural University and zoo to join the Uripok Kangchup Road that runs into central Imphal. This route is around 10 kilometres long, a considerable distance in Imphal. As Langol has grown the rest of the city is extending northwest to meet it. The road hugs the foothills as it breaks away from the densely populated localities of Imphal. The jurisdictional ambiguity and the fuzzy and poorly enforced the 'reserved forest' boundaries have enabled gradual settlement of Langol by members of different tribal communities, mostly on the northern side of the Langol Road - the hillside. The land on the southern side of the road requires title and has been divided into lots, including vast tracts reserved for various state initiatives, such as a proposed technology university, a model farm, and the Games Village. The peri-urban spaces in between Langol and the rest of the city, especially Lamphelpat, are being divided and sold to state and private developers. Even in the time I have been visiting Imphal I have watched this land go from community rice paddy and an unclaimed grazing 
area for horses and cattle (plus a large rubbish dump) to a lattice of fences and signs denoting state and private ownership.

Residents of Imphal will often cite the construction of the National Games Village and the early days of Shija Hospital in the mid-199os as the opening of this urban frontier. Certainly these developments forced the civilian authorities to consider road access to Langol, land title, and service provision. Yet this narrative suggests that Langol was empty at this time. During fieldwork throughout Langol an alternative narrative of settlement emerges. Over several decades the foothills have been settled by migrants from the hills, and to a lesser extent from other parts of the valley. This is a sensitive area and while people were willing to talk generally about what the area was like in the past, few would talk specifically about dates of settlement. Many settlements in Langol are not legal. Ambiguity around jurisdiction and the imagination of Langol as a wild and haunted place enabled migrants to move to the area unnoticed prior to the 199os. Some fled conflict in the hills, including operations by the security forces as well as underground groups. There is a whole series of villages formed in Langol following the Naga-Kuki clashes of the 199os. Some people came to Langol for land to build a house and farm, some came to hunt, some to follow others, some to escape the authorities, some because they received a celestial message.

This land was undesirable for Meiteis for whom the presence of the supernatural, a lack of roots in the area (most families build houses by subdividing ancestral land), and minimal infrastructure, forest and flooding, not to mention the presence (and rumoured presence) of underground groups representing hill communities, did little to diminish the perception of a wild frontier. The reach of the civilian government was limited in Langol even as the population grew. Though the 199os underground groups controlled the foothills; they determined who could build where, they protected residents, and they controlled movement in and out of the settlements. This could be good or bad depending on which community residents belonged to. The line between residents and underground groups is thin, many residents and their family members were and are members of these groups or of associations with close ties.

This has changed in the last decade and a half. After the National Games in 1999 the houses in the village were sold off to the public, mostly to civil servants, and awarded to successful athletes at later sporting events. The hospital acquired more land to extend its operations, including housing for staff and students. The flows of people going to and from the hospital have made the routes through Langol viable for public and private transport providers, and the route now sees a steam of auto-rickshaws, 'magic' buses (converted 


\section{Image 6.2 Baptist church under construction, Langol}

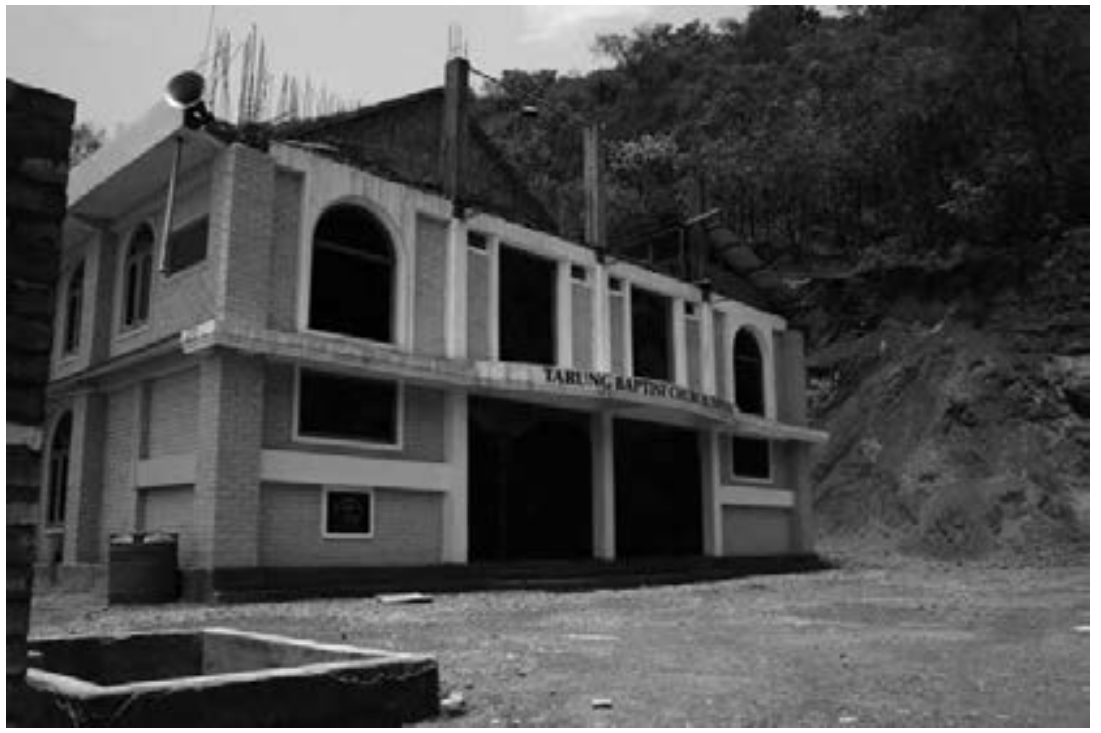

vans), and Shija's own commuter buses. Doctors started to purchase land and build houses close to the hospital. The area became a desired location for Imphal's professional classes, driving up the cost of land. Investment in guesthouses and restaurants to serve the visitors to the hospitals has increased the value of land by the road. Developers, rumoured to be backed by Imphal politicians, have levelled more of the foothills for construction. Notable among the new mansions are several drug rehabilitation homes, a yoga retreat, and a Hindu mandir (under construction in mid-2014).

Settlers from the hills continue to come to Langol. Houses were first built at the base of the foothills along the road, and then a series of terraces were cut into the hillsides behind the road and with pathways connecting them to one another. When someone wants to build they hire an excavation machine that cuts away part of the hill and levels the land - the marks from these machines can be seen all over the landscape. Some of the cleared plots have no dwellings and are cleared in order to sell to new settlers. The earth is then sold on for construction in other parts of the city. It is a fragile ecology. Some of these areas have no electricity connections or water supply. Small shops have sprung up on the roadside where the paths begin heading uphill, selling groceries and the ubiquitous second-hand clothes.

What strikes a visitor to Langol is the enormous number of churches. These are of various sizes, ages, and stages of completion. As most of the 
settlers came from the hills and are Christians, building churches has been a way to make a territorial claim in the foothills. The churches represent almost every conceivable denomination and tribal community. Residents related that building churches has a dual role; it acts to help create or recreate the community and it prevents the government from demolishing the settlements. A further tactic of marking place is to erect foundation stones. Certain stones date back to the late 1970s and early 1980s, though some residents weren't sure if these were accurate. The foundation stones are usually very well maintained, visible from the road, and are clearly valuable tools in contentious politics over land, particularly when the civilian government has plans to develop the area and some evidence of settlement will be required to negotiate for compensation.

The population of Langol is now more diverse in terms of ethnicity and especially in terms of class. What was an area for tribals escaping trouble in the hills, unwanted attention from the authorities, or better hunting options is now a part of the city. The success of Shija drew attention to Langol from the civilian authorities and private citizens, investors, developers, builders and buyers. Further, as the Games Village was allocated to only the most connected civil servants and athletes the desirability of the area grew. The peri-urban land between the city and this belt of emerging prosperity is also being claimed, occupied and transformed. The civilian authorities have made the space of the foothills and the land between them and city legible. What was wild and unruly has become tame and orderly. Those who have occupied the land for the last few decades are anxious about whether their claims to place will be recognised in the now ordered landscape. There are various tactics necessary in the struggle for permanence: churches are constantly being built, foundation stones are continually being repainted, village jubilees celebrated publically, and new settlers brought from far off villages to shore up the community. The landscape of this part of Imphal has been profoundly changed. Yet it has been the success of the private health sector on land the dominant community could not imagine settling on that has driven urban expansion into the foothills, and turned it into a zone of contention where proving community longevity is fundamental to claiming and preserving place.

\section{Conclusion}

One evening I was sitting on a rooftop in Nagamapal in central Imphal with a friend, Abung. After checking on his solar panels we shared some 
local rice beer in seclusion. After a few minutes the electricity went out. The soundscape of the power outage rang out: diesel generators cranking up, family members yelling out to one of the children to light candles, an increase in car horns honking, and sudden absence of the low din of TVs and music. Looking north from Nagamapal across the dark cityscape towards the hills we could see the outline of the hills at Langol against the night sky. Beneath it was a brightly lit constellation of buildings, the dome of Shija Hospital clear even from this distance. Abung chuckled, 'the health city'. I wasn't sure if he was marvelling at its existence, if he was angry that the city was in darkness while the hospital was lit up, or if he was just reminding me of what it was. I pressed him. 'This place...', he gestured around him shaking his head and trailed off, unable to put into words the enormity of Imphal's contradictions. And that said it all. On one level, the health city is baffling. A health hub nestled in the disturbed city where patients, tissue samples, and medical expertise move back and forth within the borderland and farther afield circumventing border security and shattering the myth of the turbulent frontier.

On another level there is some logic to the growth of the health city; not just in Langol but also throughout Imphal. As discussed in this chapter, the corrupt and inept public sector, the prevalence of human capital from decades of locals seeking medical and health qualifications, and connectivity enabling patients to move to and from Imphal to seek treatment all play a role. Yet there are other factors, murky and unseen. Rumours of silent partners, of influential backers of the various facilities abound. Unravelling these threads is difficult and dangerous, and perhaps beside the point. Endogenous liberalisation of the health sector appears accidental. It began in response to state dysfunction and the notion of a superior private sector has taken hold of the ways the health sector promotes itself and the ways urban dwellers pursue healthcare. It is not the version of liberalisation imagined by the Indian Government and set out in the various policy prescriptions discussed in the previous chapter. It is liberalisation predicated on making do, conceived in isolation and now an exemplar of connectivity; bringing Manipuri professionals home to work, training locals to work farther afield, drawing patients (and pupils) from across the borderland, and taking mobile healthcare across internal and international borders. It is also an expression of self-sufficiency. It can double as an ethno-nationalist signifier. Respondents in the sector spoke with pride about what could be achieved when the overbearing and often brutal Indian state and corrupt and dysfunctional civilian government are bypassed. In a political context shaped by decades of resistance centred in one way or another around the 
question of Manipur's sovereignty, the health sector hints at what Manipur could operate like if given a clean slate. Of course, this is a microscopic example, and one that may not be replicable in other sectors given the confluence of factors discussed above.

The Manipur Government now uses the phrase 'health city' to celebrate the concentration of high-quality private health facilities created in the vacuum caused by its own ineptitude and corruption. Yet nothing in the disturbed city is straightforward. The health city has transformed the landscape in Imphal's northwest, increasing land prices and bringing the city - and the authorities - to the periphery where families formed communities (illegally) to escape violence and attention from state and quasi-state actors. Yet even in the foothills of Langol new migrants continue to arrive from the hill districts, carving land out the hillsides, clearing haunted tracts of forest, and marking territory with churches, foundation stones, and small shops. Place is made and remade on the urban periphery - the frontier of the frontier city - always a few steps ahead of the actors seeking order and control, a scenario much less possible in the more tightly controlled neighbourhoods and wards of Imphal's core. 


\section{$7 \quad$ Education City}

Julia pointed out the car window at the stacks of timber by the roadside. 'It is admissions time'. We were driving back to Imphal from Ukhrul in June 2013. A little farther down the winding road through the denuded hills there was an even larger stack of timber being loaded onto a truck. Julia added, 'And probably there have been some new government posts advertised'. Since I had last seen her three years earlier Julia had moved from human rights activism to working as a consultant for the Manipur Department of Education. She had grown tired of the deplorable state of public education in the hills and had recruited a team of returnee migrants from the Tangkhul Naga community of Ukhrul as fieldworkers. Her team of ten men and women, mostly in their 2os, travel to all parts of the district, often on foot, to inspect and document schools and talk to community members.

I had promised to run a workshop on migration with the team in Ukhrul, also a chance to see some friends based in the town and take a break from Imphal. After listening politely to me for a while members of the team started talking about their own migration experiences and what they were witnessing happening in the district. Teachers appointed to rural schools didn't show up, private operators started schools in the town, parents borrowed money or sold timber or land to send their children to these schools, those who could sent their children to Imphal for secondary studies, and then, hopefully outside to Delhi, Bangalore, or Kolkata. In a district of 184,000 people, there were over 50 private schools. Some of these were no more than a single room on the upper floor of a house, some were implicated in the trafficking of children out of Manipur, and some were well run and had qualified and dedicated teachers. All charged money. Distance increased perceptions of quality. Thus for many parents in the hills, schools further away were considered to be better and could give their children a better chance. As private education shifts from a privilege to the norm, the hills are targeted by people lending money, offering to buy land, timber, livestock, and by recruiters from different education providers. A pattern reproduced in Imphal itself.

I was getting an idea of the initial steps families took in moving their children to towns and onto Imphal. Steps that culminated in the large numbers of migrants from this district I had met in the malls, spas, and call centres of Delhi. Most importantly for the argument in this book, I was beginning to understand how in just a few years the southwestern periphery 
of Imphal had gone from rice fields to a mini-city, a model education city to match the health city discussed in the previous chapter.

I did not want to leave the meeting with the project team but Julia was eager to get back to Imphal. It was a big day. Her research was to be published in one of the daily newspapers. A list of all the teachers who had been appointed to posts in the District but had been absent or had appointed a proxy to attend in their place was to appear on the front page. The plan was to shame the teachers and begin to orchestrate a shift in the ways teachers are appointed and retained in the state.

On the drive down from the hills she discussed typical practices she had discovered, some of which are unique to the education sector and others that reflect a general pattern of the way jobs are acquired in the public sector, and increasingly in the private sector too. A post in a school is advertised and the Department of Education is flooded with applications. To secure the post applicants must pay a bribe (between $\$ 1000$ and $\$ 5000$ USD). With lots of people offering bribes it is possible to offer a large sum and still miss out. The more desirable the post, particularly if it is in Imphal, the higher the amount needed. If an applicant does not have the necessary qualifications then the amount will be even higher. Applicants thus need to secure a large sum of money to land the post. For this many applicants, though certainly not all, borrow money or sell assets. Once the post is secured some (though not all it must be stressed) teachers do not attend their job, sporadically attend, or attend for only parts of the day. Often they are working as private tutors or teachers in private schools - indeed during interviews with private education providers in Imphal I was told repeatedly that school teachers seek out jobs in schools in order to recruit potential students for more lucrative private tuitions - mirroring the ways doctors recruit patients in public hospitals for their own private clinics. By being employed in the public school system they are better able to demonstrate their credentials to potential students and their parents. By doing so these teachers undermine the public system and simultaneously increase demand for private tuition from students to pass exams.

There is also a practice of appointing proxies. A teacher will spend the day working elsewhere, or not at all, and pay another person a portion of their salary to appear at the school. Often the proxy is unqualified and has little incentive to actually teach. The Manipur Government has responded by steadily increasing teacher salaries in the public sector, though this seems to have raised the stakes for securing a post and provided teachers with more salary to distribute to proxies. Julia's research shows that this is worse in the hill areas, where many teachers do not want to be posted so many 
never show up - hence the naming and shaming in the newspaper. The pattern is common across the state. And naming and shaming has become more common, especially in the print media where it is typical to see absent teachers named and their identity card numbers published. Furthermore non-state actors, including student unions and some underground groups undertake physical inspections of schools in various towns and urban localities and take action against absentee teachers directly or report them to the government and monitor their response. The most well-known and sustained campaign is the Eikhoi Lairik Ningthina Tamsi (loosely translated as 'Let's Study Correctly') run by the Manipur Students Federation since 2007 .

Add to this scenario the practice of teachers requesting money or 'presents' to award high marks, teachers leaving the state to work in other parts of the borderland and beyond where the conditions are more stable, routine closures of schools for bandhs, schools closing during blockades, and the mobilisation of school children in mass protests such as calling for the ILP (chapter 4) and it becomes clear why the public school system in Manipur has been declared 'near impossible to run' (Salam, 2014). The issue is not lack of schools. Indeed Manipur has a relatively high number of schools per 100,00o head of population: 150 elementary and 31 secondary compared to a national average of 97 elementary and 14 secondary (Planning Commission India, 2007:37-38). The issue is quality of education and facilities, attributes that the Manipur Government allocates funding to address, but which either fails to materialise in schools or has minimal impact on the demand for private schooling (see Manipur Planning Department, 2012).

So parents, whatever their means, aim to send their children to private schools. Despite the extreme financial pressure this can create, the desire for education and the mobility it promises is so widespread in the society that the private education sector is unlikely to diminish in importance nor is the decline of the public system likely to be stemmed anytime soon (see Singh, 2011). This has had profound impacts on the urban landscape of Imphal and reveals the ways in which connectivity plays a role in resituating the city, and Manipur generally, within India.

This chapter is about the boom in private education provision in Imphal. I am less interested in the policy and education quality dimensions, which while important and perhaps reflective of the breakdown in institutional and social life in Manipur the last 30 years, are beyond my field of expertise and beyond the scope of this book. I am interested in the emergence of Imphal as a hub for private education in the borderland; much like the health sector discussed in the previous chapter. Like the health sector the 
boom in private education appears counterintuitive. Imphal is a militarised, contentious, and often dysfunctional city, yet enormous swathes of land are now occupied by relatively expensive private schools that draw pupils from all over the city and from other parts of the state. Private coaching classes are run out of private homes. Education agents all over the city offer admission to universities and colleges in South India, Thailand, and Eastern Europe. Education providers from outside Manipur, mostly from other parts of India, recruit students from Manipur - most noticeably at the large education fairs held in Imphal in the spring. As with the health sector, providers and users of private education usually discuss its growth as a necessity; a way of making do in response to the rotten and corrupt public system; though clearly the private sector has its fair share of corruption in different ways. Yet the idea of cleansing, of starting anew, is very powerful.

If the health sector positioned Imphal at the gateway to Southeast Asia and demonstrated a localised version of the Look East Policy, the education sector is its inverse. The demand for learning the national curriculum, especially at the higher secondary level (class 11 and 12), is a crucial factor in the boom. The national curriculum is needed to qualify for tertiary study in other parts of India, where many students from Manipur can apply for reserved places. It has long been common for students with adequate support, whether from family or through scholarships, to study outside the state for higher secondary school and then progress to tertiary studies. With the growth in the provision of higher secondary schooling using the national curriculum in Imphal itself, it has become more affordable when compared to going outside and thus is equipping more and more young people from Manipur with knowledge of the national curriculum and opening the pathway to migration west to India. It is an illustration of the inward pull of citizenship, significant in the present conjuncture given the long history of resistance to Indian citizenship in Manipur.

\section{Sangaiprou}

The boom in private education has transformed the city, especially in the southwest. The main area being transformed lies between three main roads that run southwest and south out of the city: National Highway 150, Mayai Lambi Road, and the Indo-Myanmar Road/Asian Highway 1. Land that was, even in the time I have been visiting Imphal, peri-urban farmland has become a dense conglomeration of schools, hostels, and small shops. Infrastructure has been slow to catch up and brand new four-storey schools 
with reflective glass can be found at the end of muddy tracks across waterlogged rice fields. During fieldwork I focused on Sangaiprou where changes to the landscape are stark, recent, and where the idea of the education city takes its most striking physical form. The epicentre of the boom is outside the municipal boundary and outside Imphal's 27 wards. It crosses into the so-called 'outgrowth' area (Naoriya Pakhanglakpa 'Census Town') but also into areas of paddy fields and small farms. The education boom is extending the boundaries of the city.

Sangaiprou is where the oldest and most reputable Catholic secondary schools are located. As one teacher told me, 'no one can compete with the Catholic Schools up to class 10'. Proximity to the best-known schools led to a boom in this particular area from the mid-20oos. Many of the entrepreneurs who started schools were return migrants. Having spent time outside studying and working in other parts of India, returnees with some capital returned to invest in the sector. As the private education industry has boomed it has become attractive to returnees looking to make a living back home. The Manipuri diaspora has a huge public profile. Its members are frequent contributors to the local media offering their insights on living outside the state and reflections on home from afar. Many of those involved with starting schools have studied business or worked in marketing or similar fields outside the state. Successful entrepreneurs are usually returnees who have honed their skills and experience in other 'more developed' parts of India and beyond, and the very visible diaspora housing, large, multi-storey houses funded though earnings sent back from family members working outside the state (discussed in chapter 2), help to fuel the popular perceptions of the returnee as a person of status who makes things happen. Returnees also have a social standing in Imphal that helps facilitate trust, gain access to loans and finance, and open doors with officials. Of course a great many migrants return unemployed, in debt, and with few connections to make anything happen at all.

In Sangaiprou the various stages of the education boom can be seen during a brief walk through the back blocks that lie between the main roads. Labourers shovel soil and stones into damp earth making mounds to build upon. Corrugated iron sheets, steel construction rods, and bricks lie in piles at the edge of unsealed roads. Brightly painted brick walls with glass and nails embedded in cement along the top mark the boundaries of more established compounds, though inside some the buildings are still a few floors from completion. Functioning schools with names like Herbert, Zenith, Children Ideal, Comet, Modern English, Little Flower, Shemrock Bubbles, Standard Robert English, and Kids Foundation occupy buildings 
Image 7.1 School under construction, Sangaiprou

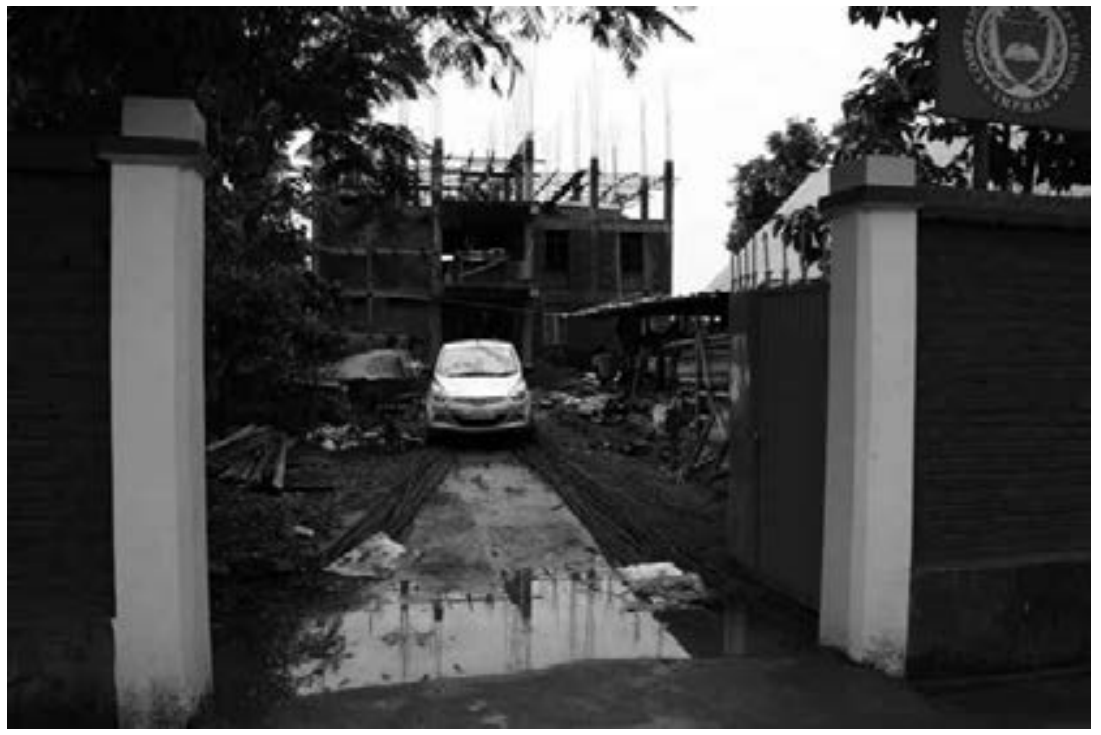

of various sizes and styles; some with brightly painted bricks, others with mirrored glass, others with patterned concrete and tiles. Hostels are found in similar buildings with walls, gates and guards and also within local houses. Some houses advertising hostel accommodation have extra floors or outbuildings added. Electricity poles and walls are plastered with advertisements for tuitions, hostel rooms, and - after exam results - banners strewn between walls and poles featuring headshots of successful students with details of their grades and position in the state in various subjects. There is also evidence of a bust accompanying the boom. Empty buildings with the school or hostel name faded or painted over, buildings sinking into the soil or with parts of wall missing, and vegetation and cattle reclaiming seldom used lots.

Costs for a year at a private school vary dramatically according to the school, whether a pupil is a day student or boarder, and the grade they are in. I have seen advertised costs for less than 3000 rupees a year (\$50 USD) for a day student in primary school to as high as 72,000 rupees a year ( $\$ 1200$ USD) for a top higher secondary including hostel costs. With so many schools it is difficult to know what is typical, or indeed if there is such a thing. Furthermore it is difficult to gauge what this means for people in Imphal and outside the city. Wages in Manipur are very difficult to track given the size of the informal sector, the supplementary income earned through other 
work and through corruption, remittances from relatives working outside the state, and the extremes of wealth and poverty evident in the state.

Initially it was difficult to research the industry. Principals and directors would happily show me their school, let me meet students, and talk about what they did. Yet they were much more reluctant to talk about finances, private tuition, staff recruitment, land acquisition and relationships with the government and underground groups. This is understandable given that private schools are accused of poaching teachers, ruining the public system, profiteering from tuitions, and of corruption in the registration of schools (money makes this happen quickly or can deter unwanted inspections of facilities or finances). Relations with underground groups may involve loans, taxation, and extortion. Land issues have also proved highly contentious with claims that the land had been illegally purchased in bulk and resold without many landowners and occupiers being informed. This will be discussed further below.

Respondents were also confused at my interest in schools. One respondent admitted to me that he was wary that I might be trying to start my own school and he wasn't ready for foreign competition. However, after hanging around Sangaiprou long enough and through existing networks in Imphal I was able to conduct in-depth conversations with education entrepreneurs. Most helpful of all was Longjam. I met Longjam through the relative of a friend. Longjam taught private tuitions from 5 in the morning until 9, and then worked as a teacher at a secondary school, and in the evenings he visited the new higher secondary school he was constructing in the fields in Sangaiprou.

We first met at his house in Sagolband Moirang, a mostly Meitei neighbourhood between the city proper and the education city. The house had been extended and took up the entire lot, the outer walls forming the boundary with the street. We sat in a very new looking reception room on the ground floor in heavy wooden chairs with carved motifs in the back and arm rests that are popular in middle and upper-middle class homes. As with most other respondents from the industry our meeting began slowly. Longjam was very softly spoken and our meeting contained some long silences that I occasionally tried to fill but eventually let them be. After half an hour we had covered most of the bases and I was getting ready to leave, tired from the uncomfortable chair and conscious that Longjam was taking time out from teaching tuitions to meet me. As I got up to leave I joked about how he needn't worry about me starting a school. He made some comment about Imphal people being too suspicious. He was an outsider too, from a small village right near the foothills in the east of the valley. I knew this 
village as the birthplace of a close friend who now lived outside the state. Longjam grew up with his brother. Though these kinds of coincidences happen a lot in a small place, Longjam acted quickly. He arranged to have his teaching commitments for the day covered by a colleague and encouraged me to shelve any plans I had. 'I will show you what is really happening', he said and led me to his Maruti hatchback and politely asked me to open the heavy gate leading to the street.

After touring the area Longjam took me to the school he is building in the back blocks of Sangaiprou. We went up to the roof on top of the third floor and looked out of the landscape, the fields turned bright green from days of rain gradually being swallowed by red bricks and grey cement, the hills to the east visible at intervals between buildings. This was where the newest construction was taking place. Longjam showed me where he was going to hold various classes when the building was complete. The school was going to be for class 11 and 12 and concentrate on preparation for engineering and medicine exams, because as Longjam said and many others have repeated, 'that is all people here care about'.

I wondered how he was going to set himself apart from all the schools that seemed to be offering the same all around us. He gestured to the landscape below, 'many of these are not good schools. By the time parents find out someone has already made some money'. Success in this market depended upon showcasing successful students. There are two main ways of presenting this. The first is to profile one or two high achieving students in the most recent exams, the second is to show the number of 'first divisioners' and to show an increase in the number of this cohort year to year. The top students become well known faces in the city following exam results, and the schools that produced them are quick to advertise the fact taking out advertisements in newspapers, billboards, and putting up banners to profile these students. Neighbourhood associations do the same, erecting banners and even billboards to congratulate the successful students from a particular locality thus perpetuating the high achievement culture. Local celebrities, usually actors and sportspersons, also bequeath awards to high achieving students, usually those from poor backgrounds. The government holds ceremonies for place-getters and gives scholarships to study outside the state. Even the armed forces present awards to the top students.

New schools without a record of achievement have to stand out by offering extras. Longjam noted the key extras were secure hostel accommodation and minimal interaction between boys and girls outside class, small teacher-student ratios, streams that group high achieving students together and provide extra support for weaker students, and promoting the national 
curriculum. There is one fee for the 'regular batch' and a higher fee for the high achieving batch, referred to as the 'super batch' at Longjam's school, who are introduced to the medicine and engineering examinations early and prepared to pass them. He was also planning to have weekly interaction with parents so they can be very involved in everything that goes on.

The quality of teachers is important and good staff hard to keep. They could earn more in the public sector since the government increased salaries, but the private sector offered even better chance to recruit children for private tuitions with smaller class sizes. Many of the buildings in Sangaiprou house tuition and coaching centres as well. Teachers were often poached to go to new centres with the promise of higher pay and smaller class sizes. In this scenario there was not much support for weaker students. Longjam insists that established schools screen applicants very carefully so that their overall performance does not lag and they can produce more 'first divisioners'. Thus competition to get into schools is fierce. Parents of poorly performing students have a difficult time gaining admission to some schools and either offer to pay higher tuition or turn to newer schools that need to build up their student numbers. Many unscrupulous operators are said to prey upon parents with limited knowledge of the sector. These operators usually don't last more than a year or two. Other schools fail when they try to have too many students and too few teachers.

Other residents make money from running hostels in their houses, opening shops near schools and hostels, extra coaching on top of extra coaching, and as agents helping students apply for further study outside. Yet the biggest cost to starting a school is acquiring land. And conversely those able to supply land, usually by first acquiring it at a low cost, are said to make the most money in the industry.

\section{Schools versus Paddy}

The drive to build more schools in close proximity to Imphal situates the education boom right in the middle of the politics around land and food production. Imphal's rapid expansion, at its most intense in Langol (as discussed in the previous chapter) and Sangaiprou, as well in the north beyond Mantripukhri, has transformed the edge of the city. Diminishing agricultural land is a contentious issue throughout Manipur exacerbated by overlapping systems of land tenure and title loosely aligned to hill/valley and tribal/non-tribal divisions, poor record keeping and the closure of the Manipur State Land Use Board, and a history of mass land acquisitions by 
the Indian Government, mostly for military use, and the Manipur Government, for development projects (Das, 1989). The Manipur Land Revenue and Land Reforms Act was implemented in 1960 to make title and transfer of land simpler in the valley. Various attempts have been made to extend the law to the hill areas, which tribal communities have strongly opposed (Tarapot, 2003: 212-13). A 2014 amendment to the act makes it easier to convert agricultural land of half a hectare (or less) for non-agricultural purposes by putting the decision for or against conversion ('diversion' in the policy) to a district committee to assess the likely benefits' and legislating only minor penalties for violations (Manipur Revenue Department, 2014:2). However, no rules are applicable in the case of acquisition of agricultural land by the state government for which there are no legislative barriers (2014: 4).

Somewhat contradictorily the Manipur Legislative Assembly passed the draft Manipur Conservation of Paddy Land Bill in July 2014. The bill seeks to prevent paddy land being used for another purpose; paddy land being differentiated from other forms of agricultural production. Critics have argued the bill does not provide protection for land that is not classified as paddy, but used for food production, and also encourages the conversion of forest and wetlands into food growing areas to create or maintain title (Yumnan, 2014). Furthermore, the New Land Use Policy, also proposed in 2014, seeks to reduce the area of the state under shifting cultivation, the main form of production in the hill areas, seen as harmful to the environment (Manipur Planning Department, 2014: 6-7). In the contemporary borderland, environmental rhetoric is used to the same effect as older arguments that used backwardness, persistent poverty, the undesirability of mobility, low yields, and inefficiency to deride shifting cultivation and the communities that practice it (Karlsson, 2011; O'Brien, 2002; Van Schendel, 1992). The New Land Use Policy contains provisions to 'rehabilitate' shifting cultivators (Manipur Planning Department, 2014:11-12). Government plans to reduce shifting cultivation in Manipur are sensitive because they align with hill/valley and tribal/non-tribal distinctions. Recognition of the need to address the loss of paddy fields is happening alongside renewed attacks on other forms of production, especially shifting cultivation, and alongside plans to accelerate commercial agriculture in Manipur to compete in the markets of Southeast Asia (Manipur Planning Department, 2014: 10-12).

In the last decade several groups have taken action on declining agricultural land, most notably the Heingang Kendra Loumi Lup and the Conservation of Paddy Lands and Natural Resources Protection Committee (CPL). The CPL mentions 'the rampant construction of schools, brick fields, 
hospitals, development of roads by farm lands, and even churches' that have rendered high yielding farmland useless (Peoples Chronicle, 2014). Some of these structures are illegal or have been purchased from someone other than the rightful landowner, usually referred to as 'land-grabbing' in Imphal, though the scale is much smaller than implied in the way the term is used in other contexts (De Schutter, 2011). Much of the agricultural land is not being transferred from smallholders to commercial entities on a large scale, it is being transferred from smallholders to other smallholders for a completely different usage; and this is what concerns the CPL given the state is already dependent on imported agricultural produce - a highly vulnerable position for residents in Imphal when the city has been cut off for months at a time during blockades. Acquisition takes place through multiple small transactions; some of which are legal, some illegal, and others that are legal on paper but involve some coercion. These don't mobilise protesters in the same way as large land-grabs despite being more common. In contrast the last decade has seen affected resident challenge large land acquisitions for the expansion of the airport, Manipur University, and for the proposed railway.

The profusion of imported rice, much of it from faraway states like Karnataka and Andra Pradesh, and the difficulties finding local rice varieties in the markets epitomises the anxiety around land-grabbing for many Imphal residents. Incidentally the rice yield in Manipur is only slightly below the national average at 2100 kilograms per hectare (Manipur Planning Department, 2013: 4), but the area under cultivation is small and the accuracy of figures is recurrently disputed. The trade in food from outside the state has long been dominated by non-Manipuris, and thus food insecurity and identity insecurity are intertwined. Dependency on non-Manipuris for food is often raised in arguments for instating the Inner Line Permit (ILP). Cheap food, mostly packaged, also comes from across the border with Myanmar and includes food manufactured there but also from Thailand, China, and even Korea (the stock of Choco-pie biscuits in Imphal seems endless). As this is a different type of food, manufactured over unprocessed agricultural produce, it doesn't figure in the exclusionary politics around the ILP.

In areas like Sangaiprou notices pasted onto walls of granaries and warehouses interspersed among the new buildings read 'Save Agricultural Lands. Save Manipur'. The same signs can be found in other areas on the edges of the city where farmland is being redeveloped. The issue highlights sharp divisions between the agrarian population of the valley, especially on the outskirts of the city, and the new purveyors of private capital investing in education and also hospitals, spiritual retreats, and shopping malls. The 
dynamics of connectivity are also at play. The boom in the private education sector that requires this land is driven by the desire of residents to leave Manipur and pursue aspirations for a better life in other parts of India. The desire to leave is also symptomatic of life in the disturbed city, where violence, surveillance, insecurity and limited livelihood opportunities (or perceptions thereof) push many young people to leave, and a higher secondary education, as well as vocational training, is a crucial component. With a large diaspora outside the state from all of the different communities of Manipur the pathways for migration, and to some extent return, become well established in the last decade (see McDuie-Ra, 2012a: 95-96). Citizenship, reservations in education institutions, and better connectivity mean most migrate to other parts of India even if they have dreams of going elsewhere.

\section{Recruiting in Imphal}

Every May since 2002 Imphal has hosted Edufest billed as 'North East's only reputed education fair'. Edufest is held at the Thau sports ground in Thangmeiband, a short walk from the new State Assembly building and in the same block as DM College, for decades the finest educational institution in the state donated by the Maharani (Queen) Dhanamanjuri Devi in 1946. During the fair, when the Thau ground is crowded with thousands of visitors and the surrounding landscape is plastered with banners, a profound juxtaposition of old and new can be seen. DM College is built on the site of Kabaw Leikai, a settlement of captives, migrants, and settlers from the Kabaw valley in Myanmar that was once under the control of Manipur (Kabui, 199ob). It has several neat single-storey brick and cement buildings with high arches and angled roofs resemble similar buildings throughout former British colonies, particularly the University of Medicine in Yangon (Lanmadaw campus).

The college grounds are expansive by Imphal standards and are one of the few nominally public spaces in the city. They are used daily by residents for recreation, badminton, for grazing polo horses, and for worship at two important Sanamahi sites. The grounds evoke a particular vision of an independent Manipur, one where royal rule would be restored - still a possibility when the college was opened in 1946. It also represents an old elite world; royal patronage, a small portion of the population entitled and interested in higher and tertiary education, and far more limited geographic imaginary. If one wanted to enter Manipur's public sector one could gain the 
necessary qualifications within Imphal. During Edufest the outer wall of this space is decorated with laser-printed banners advertising a multitude of colleges, vocational institutes, and universities in other parts of India. The advertisements feature photographs of young people dressed as air stewards, doctors, and corporate workers making their fortune somewhere else.

In 2014 Edufest was held in the badminton hall. Inside booths staffed by personnel from the institutions seeking to recruit students were neatly set out in rows. Prospective students sat for consultations and in some cases were able to apply on the spot. Most exchanges took place in English. The visiting recruiters rarely speak any of the languages of Manipur and many of the prospective students don't speak Hindi. Universities and colleges advertise their own credentials but also advertise the corporations that have recruited their students. For example, at the booth for a private university based in Punjab, some 2500 kilometres away from Imphal (around the same distance as Hanoi), there is a banner that lists 80 of the ' $300+$ Global and Indian Superbrands' that have recruited students. A quick scan of the list shows mostly banks, insurance firms, and information technology firms. At another booth the corporate logos of firms that have recruited students are featured. The sight of these well-known logos is clearly intended to add legitimacy to the institution promoting them; suggesting a pathway from Imphal to the university to these 'global' corporations.

While a few well-known private universities feature, many of the booths are rented by specialist colleges outside major cities or new universities that have yet to establish a reputation. For these institutions Imphal, and the borderland more generally, is an important recruitment ground. Some feature information on the numbers of students from Manipur on their campus. Others advertise features like air conditioned rooms and buses, affiliation with international universities (some of which appear similarly specialist, new, or with names deceptively similar to well known institutions), and extensive lists of degree programs offered. Prominent at Edufest 2014 are vocational institutes, particularly for the airline and hospitality industries. There are also more generic 'skills' training institutes; featuring pictures of air stewards, gainfully employed people holding clipboards, and the requisite male in a lab coat with a stethoscope. The motto of one reads 'Be a Global Citizen'. At a booth for the 'World's No. 1 air hostess training institute' there is a banner featuring the starting salary of previous graduates alongside a picture of a woman in an air steward uniform pulling a suitcase on wheels. There are also local vocational training institutes and schools with a presence at the fair, including the hospitality training school run by Imphal's flagship private hotel. 
Image 7.2 Advertisement for a secondary school, DM campus

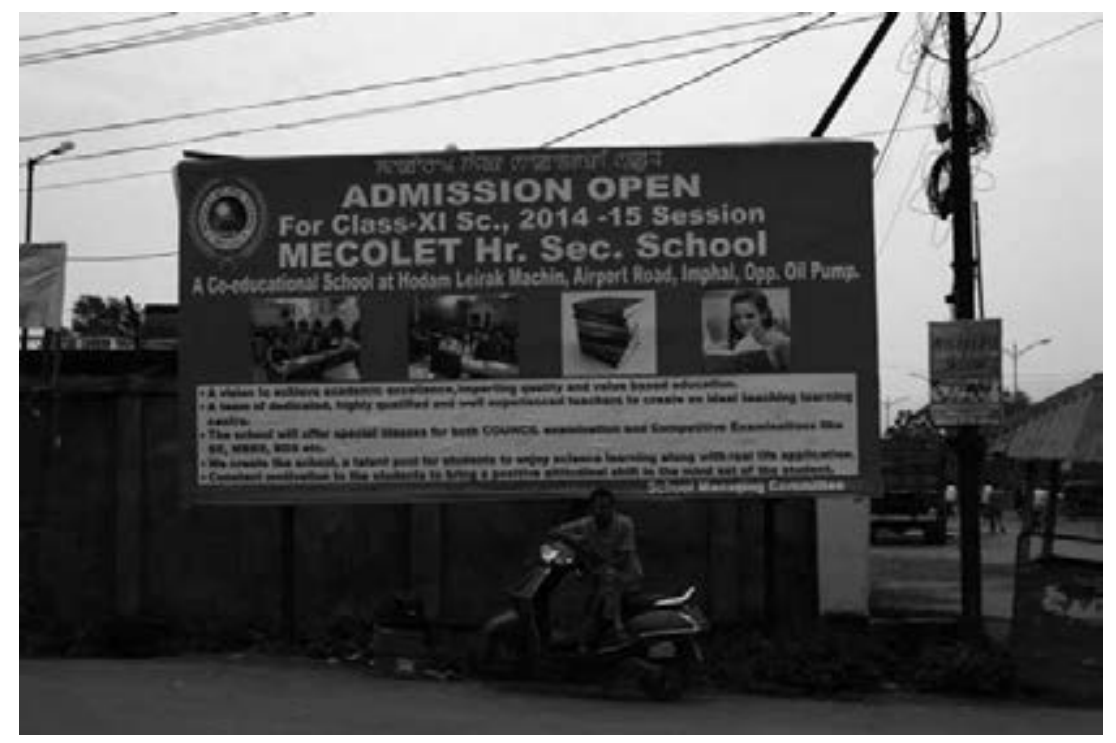

Edufest is not without competition, though many of the same exhibitors reappear and the list of sponsors is consistent across the events. Each June over the same 12-year time span Edu-options has been held, an event of similar size that specialises in getting students admitted on the spot. Since 2005 Education Fair has been run a few weeks after, and Edu-Expo has been run since 2011 twice a year. Edu-Expo has made attempts to localise its advertising and features young people from the region on its outdoor advertising; there are no obviously Indian doctors and engineers. An Education Fair has taken a different approach and features pictures of Korean television actors on its banners, rolling several of the key signifiers of the good life into one message; education, upward mobility, and pan-Asian celebrity (see McDuie-Ra, 2012a: 170-73).

Recruitment of students takes place year-round on billboards, through local career consultancies, and through recruitment agencies. Common advertisements include those for nursing colleges, mostly in South India, and colleges and universities offering engineering, medical, and business degrees throughout India, and advertisements for 'groups of institutions' that are plastered with logos of global partners but make it unclear whether they offer education or employment or both. These come and go from the cluster of billboards along the northern boundary of Kangla Fort near Khuyathong crossing along the Nambul River and around Nityaipat Chuthek 
junction. Local training institutes and recruitment agencies can be found in most commercial areas of the city and also place advertisements in the print media. During 2013 and 2014 I noticed a number of billboards advertising private boarding schools in the Himalayas; Dehra Dun, Darjeeling, Kurseong, and Kalimpong. They promote the mountain environment, extracurricular activities, and English medium education. These schools have a reputation for being very expensive and for educating the children of the old colonial and Indian elite (see Sacareau, 2007).

Imphal is an emerging market, aided by the demise of public education and the desire of the wealthy and aspiring to access ever more exclusive education for their children, for which they must either have financial means or obtain them. For poor and middle income households borrowing money, selling land or other assets, and sending siblings to other cities where one works so the other can study are common strategies to afford private education. Households with more means often aspire to education with higher costs and undertake some of these strategies but may also be able to find other ways of paying. Popular perceptions of the lifestyles of those able to extract from the state, and the private sector to an extent, extend to their children. Thus the children of 'big men' are assumed to attend the best schools in India and beyond - lifestyles that necessitate the continuation of corrupt practices. Everyone it seems is making do, taking risks and seizing opportunities for an uncertain future. There are happy and sad endings. Families who have sacrificed a great deal need it to pay off. Remittances sent back from children working in India or abroad can provide this pay off. But often the payoff is not realised. Imphal is also home to return migrants looking for work, or those who never left in the first place, unable to pass out from high school or unable to afford further education.

Imphal is part of a national education market. This may sound obvious but given the measures taken to differentiate Imphal and Manipur from a common Indian market discussed in chapter 5 , the place of Imphal in the national education market is significant. Edu-fest and other fairs place Imphal within a domestic education scene. In this scene Imphal is India's education frontier. This is a different market that one might encounter at an education fair in metropolitan India, where foreign universities (including my own) compete to attract a different group of students - those able to travel abroad for their study. This high end of the market also contains unscrupulous operators, immigration-based incentives, and unfulfilled promises, and many families get into debt to participate (Baas, 2007, 2014; Hawthorne, 2014; Robertson, 2011). Places in renowned public institutions in India - the Indian Institute of Technology, Delhi University, and 
Jawaharlal Nehru University for instance - are still sought after by students in Manipur, but these places are finite and highly competitive. They don't need to recruit; students come to them. Imphal sees a different end of the education market. The institutions sending staff to education fairs in Imphal mostly represent domestic private universities and vocational training institutes. The number of private universities has grown rapidly in response to government incentives (mostly from state governments), to meet domestic demand, to realise potential profits, as a corporate social responsibility exercise, and in response to calls to shake up the sector (Guha, 2007). There are between 187 and 316 private universities now operating in India and multiple times more colleges and vocational institutes (UGC, 2014). The lower number is the number of private universities officially recognised by the University Grants Commission (UGC). The larger number includes so-called 'deemed universities', or 'deemed to be universities' which are autonomous institutions that are treated as universities by the UGC. This includes legitimate institutions as well as fly-by-night operators and everything in between. Critics argue that private universities focus on 'looking good' and invest heavily in infrastructure and flashy facilities rather than academic quality (Nayak, 2013: 156).

Regardless, private universities need students. The borderland is an emerging and increasingly reliable market supplying this industry. There is still a frontier sensibility to the ways education is marketed in Imphal. Promises made at education fairs and through brochures don't always materialise. Deceit can go further in a place where the desire to leave is pervasive and the opportunities to do so limited. This is not to suggest that deception is the defining characteristic of selling education in Imphal. Most often it is a combination of lower tier institutions being pitched to people who may have doubts but for whom being 'outside', whether in Meerut (Uttar Pradesh) or Trivandrum (Kerala), is so important that it is worth the risk. This likely plays out in other parts of India (see Kumar, 2014), however, what makes it so remarkable in Imphal is that it reveals emerging dynamics of connectivity at work in ways completely unintended by the policymakers who tout the idea. The brain drain from cities like Imphal can hardly be a vote of confidence for the exciting future projected for the region.

As studying outside the region becomes more desirable and attainable, local institutions, especially government colleges and Manipur University (which is a central government university), miss out on potential students and vice versa. Students end up in lower tier institutions thousands of kilometres away when they could have received a cheaper (and possibly better) education in Imphal. Though corruption claims, especially in 
admissions, looms over local colleges too. Manipur's interethnic politics are also a factor. The conversion of Manipur University from a state to a central university in 2005 brought a boost in funds and salaries for staff. This also meant adopting central university policy, most controversial of which was implementing the national quota for tribals, which reserves $7.5 \%$ of university places, and removing the state quota of $33 \%$ places for tribals (Gonmei, 2013). Many tribal students unable to gain admission to Manipur University or put off by its seeming ethnocentrism have chosen to study outside the state. There is also a movement to establish a tribal university in Manipur, which has been granted, but has undergone rounds of contentious negotiation and protest before and after its completion that are beyond the scope of this chapter.

\section{Conclusion}

The micro-politics of urban transformation impelled by the desire for education and the financial savvy of those able to provide it is extending the boundaries of the city; a phenomenon witnessed elsewhere in India (see Chatterji, 2013; Raman, 2014). Yet in Imphal the booming private education sector is happening in a violent city where the state does not have a monopoly on the control of space, a city that periodically grinds to a halt from bandhs, protests, and blockades. As seen in the early chapters of this book, Imphal resembles a conflict city (see Beall et al., 2013). Such cities are not supposed to have high-tech health facilities and a booming private education sector. Reading this apparent contradiction became confounding as my time in Imphal went on. I will close the chapter by recalling a fieldwork episode that best illustrates the challenge of making sense of Imphal when read from places like Sangaiprou.

One Saturday I accompanied my friend Sonia to collect her children from a school in Sangaiprou. The school is located at the end of a raised access road off National Highway 150 passing right through the education city. We drove along the access road and on either side lay paddy fields full of water on this summer day. New construction is taking place around a hundred metres away, and a sign on the frame of a building advertises another new school coming soon. Between the gate and the school building scores of Maruti Omni vans were parked. These hold about 10 people, and even more with some creativity, and operate as school buses. As is often the case in Imphal many of the vans had registration plates from other states. Imphal is a popular destination for stolen cars from other parts 
of India that are resold on the black market and also 'legalised' by being resold by dealers who can smooth over the paperwork with the relevant authorities. When we arrived at the gate we could not get past all the vans so we walked between them. Each van serves a group of parents who pay the driver directly. The driver collects the children in the morning from their neighbourhood and then drops them off, works doing other jobs, and then goes to collect the children at the end of the day. In the past children would walk to their neighbourhood public school. This was now considered unsafe. Also, children travel much further to school than in the past, the neighbourhood public school system having almost disappeared and the new schools being built further out of the city.

The school building was impressive. Built over three floors in a semicircle, it was made of brightly painted bricks and had an enclosed play area and a garden; all behind a heavy gate and high fence. We arrived early and waited with the van drivers and other parents in the shade outside and talked about the school. Sonia liked this school because they had small classes, good teachers, and didn't do the kind of rote learning she remembers from her school days. Indeed, placards featuring an outline of the education philosophy of the school were featured near the entrance. As we waited two men in state police uniform armed with machine guns walked to the gate followed by a parent, 'a minister' whispered Sonia, and a further two armed men behind. Like us they waited at the gate for school to finish.

The scene confounded me. Was this thriving school out in the fields, one of many in the vicinity, sign of a society that has healed or one that is broken? The abject failure of the local state to control corruption had badly affected the public school system, among other aspects of social and economic life. Similarly the disruptions caused by bandhs and blockades by non-state actors exacerbated the problem. Violence and impunity for the armed forces produced a lived environment that people were desperate to leave, and education has been normalised as one of the best ways to get out and either stay out or come back with some capital to get ahead. These were all symptoms of the disturbed city; where sovereign power is deployed for territorial control, security, and to showcase development projects leaving other aspects of governance to decay.

The scene could also tell a different story. Is this resilience? Making do on large scale? Or even of the 'new politics' of middle class community participation in governance outside the sphere of conventional representative democracy (see Harriss, 2011)? A decaying public education sector, part of a larger public malaise, necessitates action - particularly in a society where education is highly valued as a means to migrate and generate remittances 
but also as an end in itself (Singh, 2011). Action on education appears to transcend class boundaries. People will generally do whatever they can to access it, as the piles of timber by the Ukhrul-Imphal road illustrate. Even when education does not bring the desired return it is a signifier of being modern and of at least giving oneself, and one's children, a better chance than the ones available in the past and the present. Unlike the situation for some other communities in India, notably Dalit communities studied by Jeffrey et al., $(2004,2005)$ it is not the expansion of state affirmative action policies that have broadened the appeal and uptake of education (and its unrealised promises) but uncoordinated private activity in spite of the state. Tuitions, private schools, and private investment in education, all of which further the decline of the public system, can be rationalised as necessary in the face of state dysfunction and corruption. Outside providers have taken note and come to Imphal several times a year to offer places in institutions far and wide. Potential students gather information and make a decision about where to apply based on their scores, their means, and perceptions of the quality and opportunities on offer. Yet not all consumers are equal in this marketplace, those with lower scores and/or lesser means have fewer choices; some have none at all. In effect it resembles an extreme neoliberal scenario. One arrived at almost by accident.

Clearly there are related elements at play: disturbed city, dysfunctional governance, a resilient population, and aspirations for success outside. Sangaiprou and the education fairs provide a powerful physical manifestation of the private education boom. Decaying public schools visible throughout the city provide a stark contrast: buildings in poor condition, few pupils, and sometimes just a caretaker and no teachers. There are healthier examples; especially some public secondary schools and colleges, including DM College mentioned above. The flipside of the boom are much less visible; household debt, education scams, qualified young adults with no work, and the loss of peri-urban farmland. Even less visible is the murky world of land transactions, corruption in school licensing, and taxes paid to underground groups. The privatisation of the education sector still depends, in part, on the dysfunctional state apparatus and the other sources of power that make things happen in Imphal. In other words it is doubtful whether such a boom would be possible without the 'transgression and erosion' of sovereign power characteristic of sensitive space (Dunn and Cons, 2014: 104), the defining character of the disturbed city. Yet these transgressions are unlike protests, smuggling, squatting, rebel memorials and hunger strikes. They come in the form of schools promising to meet aspirations that transcended class in contemporary Manipur, aspirations the state cannot enable. 



\section{Conclusion}

On a Saturday morning in December 2012 I attended a rally protesting crimes against women and children in Manipur. In the warm winter sun a crowd gathered in Haobam Marak Lourembam Leikai on the grass outside the Meitei Artistes Union building on Mayai Lambi Road, a long road from the centre of the city out to the south of the Imphal valley. Women from different ethnic groups and different ages - from school children to matriarchs - milled around while members of the organising NGO arranged them into different sections ready to march. Protestors held placards in different scripts, Meitei Mayek, Bengali, and Latin. Slogans like 'We Want Justice' and 'Repeal AFSPA' were common among the marchers. There were also placards featuring the names of people killed, raped or tortured. Some of these feature the date and the police station where the incident was reported. One marcher held a sign warning 'Don't Invite Women War'. A local politician flagged off the rally surrounded by press photographers and in the presence of some notable local film stars.

One side of the road was closed for the rally. Even then there were hardly any cars on the route. The long line of marchers snaked past cement outer walls, clay and thatch houses, timber mills, and construction sites. A small van with loudspeakers mounted on top crawled alongside the marchers calling out slogans. A press vehicle drove alongside taking photographs. Some journalists I knew offered me a lift and drove me to the end point of the rally, a community hall at Pishumthong - opposite a statue of Irabot Singh, where we climbed the upper floor for a better view. We couldn't see the end of the line of marchers heading towards us, in part because of the hazy winter light, but also because there seemed to be so many marchers.

The mandop alongside the hall filled up as the marcher's arrived. A breeze came off the Nambul River, which flowed at the bottom of the embankment just behind. The special guests stood at the front: the film stars, a few officials, and some well-known activists. Behind them a banner read in English 'Public Meeting on Crimes Against Women and Children in Manipur' with a list of supporting organisations beneath it. Some Meitei Mayek was scrawled hastily above the text in a different colour outside the borders of the banner, obviously a late inclusion. The event featured a number of speakers who told of their personal experiences with violence, with elusive justice, and with harassment by the armed forces. Widows of men disappeared spoke of the challenges getting by. Relatives of alleged suicides spoke of their suspicions of murder. Activists then spoke about the 
importance of knowing one's rights and what to do if they experience or witness violence. The distress shown by many of the speakers and the audience was accompanied by resoluteness: to fight on and to build connections across the divisions between residents of the city, whether on gender, class, or ethnic lines. Here residents demonstrated their agency, albeit in limited circumstances, challenging the armed forces, the civilian government, local law enforcement, and the society more broadly to end violence.

The public meeting at Pishumthong took place across the Nambul River from Chinga Ching, a hilltop in Singjamei locality. The hill is occupied by the Assam Rifles and has been the scene of a number of attacks over the years, including a bomb blast just 16 days prior to the rally in 2012. As the public meeting went on, armoured vehicles could be seen climbing and descending the winding road curving up the hill through the open walls of the hall. The public meeting created a space for people to share their experiences of violence and advocate for justice. The looming Assam Rifles base in the background served a brutal reminder of the realities of sensitive space - of violence and injustice in the disturbed city.

I remarked on this juxtaposition to Daniel, a photographer standing next to me at the rear of the public meeting whom I recognised from a drinking den. Daniel looked confused and asked, 'where else can people protest?' He went on to tell me that rallies were no longer allowed in city centre. That is why this rally was held on a road out of town. Pishumthong was as close as they were allowed to get to the city centre for the public meeting. After the armed forces were humiliated by the naked protests by the Meira Paibis out the front of Kangla Fort in 2004 laws were passed moving all rallies away from symbolic sites, the main markets, armed forces headquarters, and the state assembly. Permission to rally must be given by the District Commissioner. I was witnessing agency by residents against powerful institutions that deeply affected their lives, but the rallies were segregated from the rest of the city. Sit-in protest in neighbourhoods were tolerated, but anything else, such as the protests around the ILP in the centre of the city, were met with force by the state police, as I found out on later visits. Spatial control was in effect, letting residents oppose the armed forces and the government but making sure they did it in the outskirts of the city.

As the public meeting disbanded, and after I shamelessly posed for photos with one of the Manipuri film stars, I walked over the Pishumthong Bridge, the covered walkway on one side occupied by vegetable and fish vendors, past the entrance to the Assam Rifles base at the foot of Chinga Ching and along a back road to the Indo-Myanmar Highway, or Asian Highway 1, at Singjamei. There was a traffic jam heading into Imphal. A van piled with 
Image 8.1 Start of the rally, Haobam Marak Lourembam Leikai

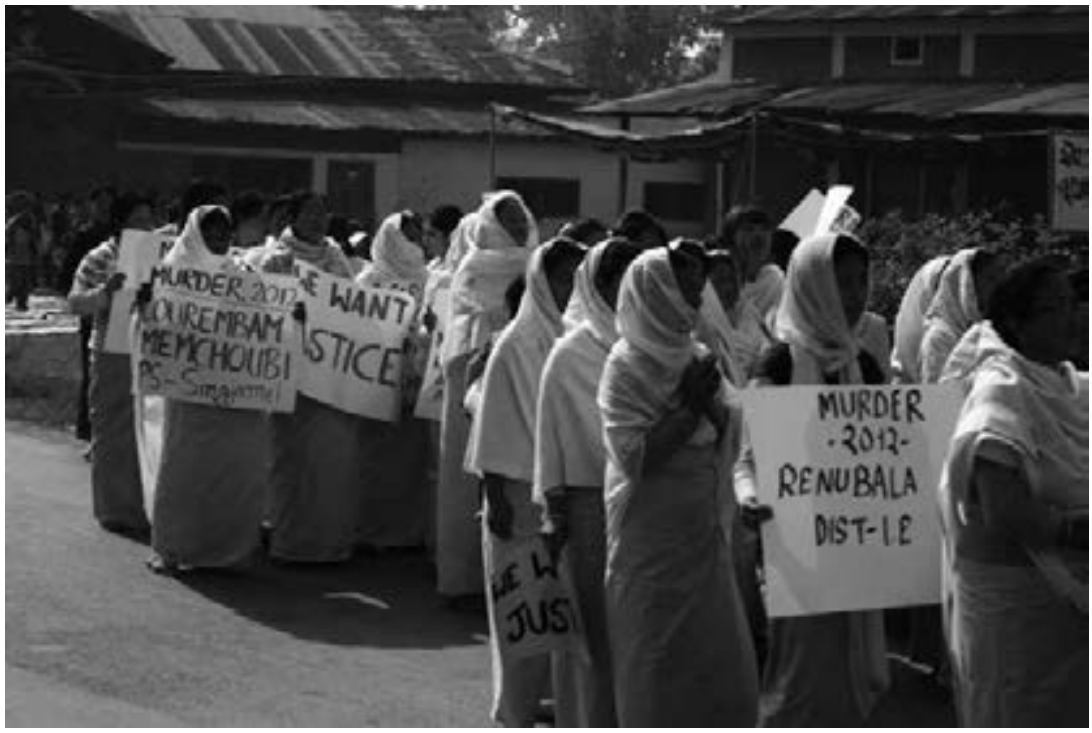

goods from the border market at Moreh had lost its load as it took the sharp right turn for the final stretch into the city. On both sides of the road red and blue plastic basins, stools, and tied bundles of blankets in plastic covering were scattered. One of the passengers was trying to pick them up while two police spoke to the driver. A man got out from the vehicle behind, itself laden with mattresses, and helped collect the scattered goods and soon the traffic was flowing again.

As the vehicles started up and began to ply the road in both directions the contrast between the vehicles hurtling along the Indo-Myanmar Highway and the slow march of women protestors along Mayai Lambi Road half a kilometre away struck me as a fitting metaphor for the disturbed city in an age of connectivity. Contradictory mobilities are enacted side by side. Transnational flows of goods transforming the frontier to a corridor, the border city into a gateway city. Yet the gateway city itself is controlled by the armed forces, a dysfunctional civilian government, and subject to bandhs, blockades, and ethnic divisions that restrict mobility and orchestrate the decisions residents make in their everyday life about where to walk, where to shop, who to greet.

This book has explored space and place in the disturbed city where spatial control is enacted by state, quasi-state and non-state actors. Attention to these dynamics demonstrates the ways spatial control is constituted 
and contested beyond a standard binary between state power and non-state resistance. In Imphal spatial control is diffused among the armed forces and the civilian government as they attempt to control space both in collaboration and in competition. Protest, memorial and the demarcation of neighbourhoods are all attempts to challenge the spatial practices of the armed forces and civilian government, attempts to make place to return to the concepts discussed in chapter 1 . In this context creating a sense of belonging, or place, can affirm ethnic boundaries, especially during episodes of tensions between communities, and this has produced a patchwork urban landscape where experiencing belonging depends upon exclusion, mostly of other residents. While this challenges the power of the civilian government and armed forces, the resulting disorder legitimises their control.

The city also contains plural places where residents gain a sense of belonging, even if momentarily, that attests to other ways of realising identity beyond, and adjacent to, ethnicity. These places revolve around sport, popular culture and alcohol consumption. As such they are unlikely to pose a major challenge to the hegemony of the armed forces and civilian government or to the nexus of non-state actors that control neighbourhoods. Yet in a disturbed city like Imphal these seemingly insignificant and even trivial places play a crucial role in interethnic friendship and alternative ways of belonging. Despite requiring vigilance to seek out, these places are worthy of serious analysis in similar contexts as they show the way plurality is lived out in otherwise polarised urban spaces.

The book also explores the liberalisation of sensitive space. Despite the official discourse of an imaginary future where goods, people, and production move in and out of the gateway city, connectivity is utilised very differently by residents to make do by selling clothing, make money by building schools to equip young people to leave the city, and make demands on the Manipur and Indian Government for greater territorial control by blocking and threatening to block the highways on which connectivity is built. Furthermore, connectivity intensifies anxiety over migration into Imphal by non-Manipuris. Greater accessibility removes the natural barriers to cultural protection, though what makes the politics of migration in the borderland interesting is that they predominantly focus on controlling the influx of co-citizens from the rest of the country, illustrating the legacy of lost sovereignty and of the gap, racial and cultural, between the TibetoBurman communities of this part of the borderland and the dominant 'national' culture of India (albeit highly caricatured). A counter-movement to control the settlement of non-Manipuris meets the transformation of the frontier into a corridor, enforcing a unity, perhaps felt or perhaps wholly 
instrumental, between Manipur's indigenous ethnic communities who are otherwise engaged in tense relationships over land, institutional representation, and their own territorial dreams.

Seemingly at odds with all of these developments are Imphal's booming private health and education sectors. Their success demonstrates the inadequacy of service provision by the civilian government worn away by corruption, patronage, and diminishing sovereignty. Yet they also demonstrate alternative imaginings of connectivity: the desire to leave Imphal by studying outside, and the desire to invest in Imphal by making it a health hub for the borderland that will draw patients from other polities nearby. These booms have dramatically altered Imphal's landscape and stretched the boundaries of the city generating new struggles over place in the peri-urban fringe.

Further research into liberalisation in other Asian borderlands is an important accompaniment to the rich literature on state-led development in borderlands. In spaces where the state has been resisted, or where it never really took a firm hold, liberalisation can be hawked as an alternative pathway to development, to fulfilling aspirations, to possible futures. Liberalisation may be embraced, contested, or manipulated by different actors in the borderlands, though it is likely that liberalisation takes a different form in borderlands than in heartlands. I do not wish to suggest that liberalisation is a panacea to the violence of state-making or the misery of occupation, rather liberalisation of borderlands opens highly sensitive and securitised space to new and intensified flows of goods, people, and capital. This appears contradictory and it is worth considering whether state control of borderlands in necessary for liberalisation, if it makes state control more possible, if one precipitates the other, or if liberalisation can keep complete state control in abeyance and generate and endogenous economy that may increase the prospects of autonomy and self-sufficiency.

Cities are where the politics of connectivity, whether enabled or denied by the state, play out. Cities in borderlands are remarkable urban environments. On the one hand they can be crucial spaces for state control - to mark claims to territory with symbols and institutions, to host security forces deployed to maintain control, and implement development projects that help foster a sense of nationhood, patronage, and loyalty. On the other they can be epicentres of anti-state activity, hubs of licit and illicit crossborder flows and networks, and plural spaces of residents, migrants and sojourners from within and across borders. They are ideal sites to explore the lived experienced of connectivity and its discontents. They are also ideal sites to explore more conventional questions of urban studies in the 
context of dramatic changes often obscured by a focus on global cities and mega-cities. Global cities and mega-cities are revered as glimpses of the future: embodiments of $21^{\text {st }}$-century globalisation, planning, technology and their negative consequences. In Asia where opening internal and external borders is transforming the lands 'in-between' sovereign states - including territories within their own borders previously outside central government control, a vernacular urbanism of borderland cities is awaiting further exploration. 


\section{Acronyms}

NB: Frequently used acronyms only

AFSPA Armed Forces (Special Powers) Act $195^{8}$

ASEAN Association of South East Asian Nations

CISF Central Industrial Security Force

CPL Conservation of Paddy Lands and Natural Resources

Protection Committee

CRPF Central Reserve Police Force

ILP Inner Line Permit

JCILPS Joint Committee on the Inner Line Permit System

KSDC Kuki State Demand Committee

MDONER Ministry of Development of North Eastern Region

MEELAL Meetei Erol Eyek Loinashillon Apunba Lup (organisation advocating and enforcing compulsory use of Meitei Mayek script)

NEC North Eastern Council

NEIIPP North East Industrial and Investment Promotion Policy 2007

NEV2020 North Eastern Region Vision 2020

NSCN-IM National Socialist Council of Nagaland (Isak-Muivah)

RSBY Rashtriya Swasthya Bima Yojana (National Health Insurance Programme)

SHDDC Sadar Hills Districthood Demand Committee

UGC University Grants Commission

VDF Village Defence Force 



\title{
Glossary of Non-English Terms
}

\author{
NB: Excluding place names and ethnic/tribal group names
}

\begin{tabular}{|c|c|}
\hline bandh & $\begin{array}{l}\text { General strike affecting an area, city or } \\
\text { entire state, usually enforced by volunteers }\end{array}$ \\
\hline hoho & $\begin{array}{l}\text { Traditional institution or council of } \\
\text { the Naga communities in Manipur and } \\
\text { other parts of the borderland }\end{array}$ \\
\hline innphi & Shawl worn by Meitei women \\
\hline ising kongs & $\begin{array}{l}\text { Drainage channels used throughout the } \\
\text { Imphal valley to prevent flooding }\end{array}$ \\
\hline keithel & Market \\
\hline lai & Pre-Hindu Meitei deities \\
\hline Lai Haraoba & Annual Meitei festival paying tribute to lai \\
\hline laishang & $\begin{array}{l}\text { Temple, house or shine where lai are } \\
\text { worshipped }\end{array}$ \\
\hline mandop & $\begin{array}{l}\text { Pavilion with an earth floor and open } \\
\text { walls used for meeting, games, and } \\
\text { performances }\end{array}$ \\
\hline mayang & A non-Manipuri \\
\hline Meira Paibis & $\begin{array}{l}\text { Community association of married } \\
\text { Meitei women active on social issues, } \\
\text { including violence by the armed forces } \\
\text { and territorial politics }\end{array}$ \\
\hline Meitei Mayek & $\begin{array}{l}\text { The traditional script for the Meitei } \\
\text { language (revived in the 199os to } \\
\text { replace the Bengali script) }\end{array}$ \\
\hline Meiteilon & Meitei language \\
\hline Nupi Lal & $\begin{array}{l}\text { The Women's War; Refers to the 'First } \\
\text { Women's War' in } 1904 \text { against forced } \\
\text { labour by the colonial authorities and/ } \\
\text { or the 'Second Women's War' in } 1939 \\
\text { against a famine attributed to colonial } \\
\text { authorities }\end{array}$ \\
\hline phanek & Meitei sarong or skirt \\
\hline pukhri & $\begin{array}{l}\text { Pool or pond in a family compound or } \\
\text { neighbourhood }\end{array}$ \\
\hline pung & Manipuri drum \\
\hline
\end{tabular}


Sanamahi/Sanamahism Pre-Hindu Meitei faith

selhunbi

Moneylender

yek

Meitei clans

yumjao

Traditional Meitei architecture 


\section{References}

Abraham, Itty. 2014. How India Became Territorial: Foreign Policy, Diaspora, Geopolitics. Palo Alto: Stanford University Press.

Agamben, Giorgio. 1998. Homo Sacer: Sovereign Power and Bare Life. Trans. Daniel Heller-Roazen. Palo Alto: Stanford University Press.

-. 2005. State of Exception. Trans. Kevin Attell. Chicago: University of Chicago Press.

Aghion, Philippe, Robin Burgess, and Stephen J. Redding. 2008. 'The Unequal Effects of Liberalization: Evidence from dismantling the license raj in India'. American Economic Review $98(4): 1397-412$.

Akoijam, Sunita. 2010. 'Home before Dark'. Himal Southasian 23 (7): 55-56.

Appadurai, Arjun. 1996. Modernity at Large: Cultural dimensions of globalization. Minneapolis: University of Minnesota Press.

ASEAN. 2004. 'Address by the Secretary-General of ASEAN, Conference on Northeast India's Gateway to ASEAN, 22 November 2004, IIT, Guwahati'. http://www.asean.org/resources/2012-02-10-08-47-56/speeches-statements-of-the-former-secretaries-general-of-asean/ item/first-india-asean-car-rally-2004.

ASEAN-India. 2012. 'Remarks by Prime Minister, Dr Manmohan Singh at flag down of the ASEAN-India Car Rally', 21 December. https://www.youtube.com/watch?v=ueiwgvgRDeQ

Baas, Michiel. 2007. 'The Language of Migration: The education industry versus the migration industry'. People and Place 15 (2): 49-60.

Baishya, Amit. 2010. 'CCounter Me, Rape Us": Bare life and the mimicry of the sovereign'. In Subaltern Vision: A study of Indian Postcolonial English text, ed. Aparajita De, Amrita Ghosh and Ujjwal Jana, 134-81. Newcastle upon Tyne: Cambridge Scholars Publishing.

-. 2015. "The Act of Watching with One's Own Eyes: "Strange recognitions" in An Outline of the Republic'. Interventions: International Journal of Postcolonial Studies 17 (4): 603-20.

Balarajan, Yarlini, Selvaraj, S., \& Subramanian, S.V. 2011. 'Health care and equity in India'. The Lancet, 377 (9764): 505-515.

Banerjee, Himadri. 2012. 'The Other Sikhs: Sikhs of Manipur in twentieth century'. Sikh Formations 8 (1): 87-112.

Banerjee, Paula. 2008. Women in Peace Politics. New Delhi: SAGE Publications India.

Banerjee, Sumanta. 2004. 'India's “Home Front”'. Economic and Political Weekly 39 (40): 4404-6.

Barbora, Sanjay. 2008. 'Autonomous Districts and/or Ethnic Homelands: An ethnographic account of the genesis of political violence in Assam (Northeast India) against the normative frame of the Indian Constitution'. International Journal of Minority Group Rights 15: 313-34.

Baruah, Sanjib. 2003. 'Nationalizing Space: Cosmetic federalism and the politics of development in Northeast India'. Development and Change 34 (5): 915-39.

-. 2005. Durable Disorder: Understanding the politics of Northeast India. New Delhi: Oxford University Press.

Basavapatna, Sahana. 2012. 'Chins in Mizoram: The case of borders making brothers illegal'. Journal of Borderlands Studies 27 (1): 61-72.

Beall, Jo, Tom Goodfellow, and Dennis Rodgers. 2013. 'Cities and Conflict in Fragile States in the Developing World'. Urban Studies 50 (15): 3065-83.

Bell, David, and Mark Jayne. 2009. 'Small Cities? Towards a research agenda'. International Journal of Urban and Regional Research 33 (3): 683-99.

Berman, Peter, and Rajeev Ahuja. 2008. 'Government Health Spending in India'. Economic and Political Weekly 43 (26/27): 209-16. 
Bhadra, Gautam. 1975. 'The Kuki Uprising (1917-1919): Its causes and nature'. Man in India 55 (1): $10-56$.

Bhan, Gautam. 2009. “This Is No Longer the City I Once Knew”. Evictions, the urban poor and the right to the city in millennial Delhi'. Environment and Urbanization 21 (1):127-42.

Bhaskar, Venkataraman, and Bishnupriya Gupta. 2007. 'India's Development in the Era of Growth'. Oxford Review of Economic Policy 23 (2): 135-42.

Bhaumik, Subir. 2005. 'Book Arson "a Taleban-style” Act. http://news.bbc.co.uk/1/hi/world/ south_asia/4443565.stm.

-. 2009. Troubled Periphery: Crisis of India's North East. New Delhi: SAGE.

Black, David. 2008. 'Dreaming Big: The pursuit of "second order" games as a strategic response to globalization'. Sport in Society 11 (4): 467-80.

Bollens, Scott A. 2012. City and Soul in Divided Societies. Abingdon: Routledge.

Bora, Papori. 2010. 'Between the Human, the Citizen and the Tribal: Reading feminist politics in India's Northeast'. International Feminist Journal of Politics 12 (3-4): 341-6o.

Brubaker, Rogers. 2006. Nationalist Politics and Everyday Ethnicity in a Transylvanian Town. Princeton, NJ: Princeton University Press.

Bunnell, Tim, and Anant Maringanti. 2010. 'Practising Urban and Regional Research beyond Metrocentricity'. International Journal of Urban and Regional Research 34 (2): 415-20.

CCEA (Cabinet Committee on Economic Affairs). 2007. North East Industrial and Investment Policy. New Delhi: Ministry of Commerce and Industry, 10(3)/2007-DBA-II/NER.

Census of India. 2013. 'CensusInfo India: Manipur'. http://censusindia.gov.in/2o11census/ censusinfodashboard/index.html.

Chakravarti, Anand. 2012. 'Conscience of the Constitution and Violence of the Indian State'. Economic and Political Weekly 47 (47-48): 33-38.

Chakravarti, Paromita. 2010. 'Reading Women's Protest in Manipur: A different voice?' Journal of Peacebuilding and Development 5 (3): 47-6o.

Chatterjee, Shibashis. 2007. 'Conceptions of Space in India's Look East Policy Order: Cooperation or community?' South Asian Survey 14 (1): 65-81.

Chatterji, Tathagata. 2013. 'The micro-politics of urban transformation in the context of globalisation: A case study of Gurgaon, India'. South Asia:Journal of South Asian Studies 36 (2):273-87.

Chattopadhyay, Swati. 2012. Unlearning the City: Infrastructure in a new optical field. Minneapolis: University of Minnesota Press.

Chhibber, Pradeep, and Rahul Verma. 2014. “The BJP's 2014 "Modi Wave”: An ideological consolidation of the right'. Economic and Political Weekly 49 (39), 27 September.

Cons, Jason. 2016. Sensitive Space: Fragmented Territory at the India-Bangladesh Border. Seattle: University of Washington Press.

Copping, Jasper. 2013. 'Second World War Clashes Named as “Greatest British Battle"'. The Telegraph, April 20.

Corbridge, Stuart, and John Harriss, 2000. Reinventing India: Liberalization, Hindu nationalism and popular democracy. Cambridge: Polity Press.

Cornelissen, Scarlett. 2010. 'The Geopolitics of Global Aspiration: Sport mega-events and emerging powers'. International Journal of the History of Sport 27 (16-18): 3008-25.

Das, Jitendra Nath. 1989. A Study of the Land System of Manipur. Guwahati: Law Research Institute, Eastern Region.

De, Debasree. 2014. 'Nehruvian Vision of Sustainable Development for Tribals in India: A critique'. South Asia Research 34 (1): 1-18. 
Denis, Eric, Partha Mukhopadhyay, and Marie-Hélène Zérah. 2012. 'Subaltern Urbanisation in India'. Economic and Political Weekly 47 (30): 52-62.

De Schutter, Olivier. 2011. 'How Not to Think of Land-grabbing: Three critiques of large-scale investments in farmland'. The Journal of Peasant Studies 38 (2): 249-79.

Dobhal, Harsh. 2009. Manipur in the Shadow of AFSPA: Independent People's Tribunal report on human rights violations in Manipur. Imphal: Socio Legal Information Centre.

Downie, Edmund. 2015. 'Manipur and India's “Act East” Policy'. The Diplomat, February 25.

Dunn, Elizabeth Cullen, and Jason Cons. 2014. 'Aleatory Sovereignty and the Rule of Sensitive Spaces'. Antipode 46 (1): 92-109.

Dupont, Veronique. 2008. 'Slum Demolitions in Delhi since the 1990s: An appraisal'. Economic and Political Weekly 43 (28): 79-87.

D'Wai, Homen, dir. 2013. VDF Thasana. Imphal: Robin Colour Films. [Film]

Dwyer, Owen J., and Derek H. Alderman. 2008. 'Memorial Landscapes: Analytic questions and metaphors'. Geojournal 73 (3): 165-78.

Economic Times. 2013. 'Automakers like Maruti, Honda, GM Turn towards Northeast, Eye 5opc Jump in Sales'. Economic Times, August 13.

Economist, The. 2007. 'The Mayhem in Manipur; India's wild Northeast'. The Economist. March 3. Eilenberg, Michael. 2012. At the Edges of States: Dynamics of state formation in the Indonesian borderlands. Leiden: Brill.

Feenstra, Anne. 2008. 'Kitschy Kabul Wedding Cake'. Himal Southasian 21 (10/11): 35-37.

Ferguson, James, and Akhil Gupta. 2002. 'Spatializing States: Toward an ethnography of neoliberal governmentality'. American Ethnologist 29 (4): 981-1002.

Fernandes, Leela. 2006. India's New Middle Class: Democratic politics in an era of democratic reform. Minneapolis: University of Minnesota Press.

Friedmann, John. 2007. 'Reflections on Place and Place-making in the Cities of China'. International Journal of Urban and Regional Research 31 (2): 257-79.

Gaikwad, Namrata. 2009. 'Revolting Bodies, Hysterical State: Women protesting the Armed Forces Special Powers Act (1958)'. Contemporary South Asia 17 (3): 299-311.

Ganguly-Scrase, Ruchira, and Timothy J. Scrase. 2009. Globalisation and the Middle Classes in India: The social and cultural impact of neoliberal reforms. Abingdon/New York: Routledge.

Gazit, Nir. 2009. 'Social Agency, Spatial Practices, and Power: The micro-foundations of fragmented sovereignty in the occupied territories'. International Journal of Politics, Culture, and Society 22 (1): 83-103.

Ghosh, Soumitra. 2014. 'Publicly-Financed Health Insurance for the Poor: Understanding RSBY in Maharashtra'. Economic and Political Weekly 49 (43/44): 93-99.

Gonmei, G. Hiamguanglung. 2013. 'Hills Economy of Manipur: A structural change'. Journal of North East India Studies 3 (1): 61-73.

Goswami, Roshmi, M.K. Sreekla, and Meghna Goswami. 2005. Women in Armed Conflict Situations. Guwahati: North East Network.

Guha, Ramachandra. 1999. Savaging the Civilized: Verrier Elwin, his Tribals, and India. New Delhi: Oxford University Press.

- 2007. 'Pluralism in the Indian University'. Economic and Political Weekly 42 (7):564-70.

Gupta, Akhil and Kalyanakrishnan Sivaramakrishnan. 2011. 'Introduction: the state in India after liberalization'. In The State in India After Liberalization: Interdisciplinary perspectives, ed. Akhil Gupta and Kalyanakrishnan Sivaramakrishnan, 1-27. Abingdon/New York: Routledge. 
Hanjabam, Shukhdeba Sharma. 2008. 'The Meitei Upsurge in Manipur'. Asia Europe Journal 6 (1): 157-69.

Haokip, Thongkholal. 2012. 'Decades of Sadar Hills Demand'. JNEIS Comment/Journal of North East India Studies (May-June): 20-28.

—. 2013. 'The Kuki-Naga Conflict in the Light of Recent Publications'. South Asia Research 33 (1): $77-87$.

-. 2015. India's Look East Policy and the Northeast. New Delhi: Sage.

Harris, Tina. 2013. Geographical Diversions: Tibetan trade, global transactions. Athens: University of Georgia Press.

Harriss, John. 2011. "New Politics" and the Governmentality of the Post-liberalization State in India: An ethnographic perspective'. In The State in India After Liberalization: Interdisciplinary perspectives, ed. Akhil Gupta and K. Sivaramakrishnan, 91-108. Abingdon/New York: Routledge.

Harvey, David. 2005. A BriefHistory of Neoliberalism. New York: Oxford University Press.

Hawthorne, Lesleyanne. 2014. 'Indian Students and the Evolution of the Study-Migration Pathway in Australia'. International Migration 52 (2): 3-19.

Hazarika, Sanjoy. 2004. 'Land, Conflict, Identity in India's Northeast: Negotiating the future'. Futures 36 (6): 771-80.

Herscher, Andrew. 2010. Violence Taking Place: The architecture of the Kosovo conflict. Stanford, CA: Stanford University Press.

Hoelscher, Steven, and Derek H. Alderman. 2004. 'Memory and Place: Geographies of a critical relationship'. Social and Cultural Geography 5 (3): 347-55.

HRW. 2008. These Fellows Must Be Eliminated:Relentless violence and impunity in Manipur. New York: Human Rights Watch.

Hsueh, Roselyn. 2012. 'China and India in the Age of Globalization: Sectoral variation in postliberalization reregulation'. Comparative Political Studies 45 (1): 32-61.

Hueiyen Lanpao. 2011. 'The Alarming Scarcity Of Oxygen Cylinders in Three Major Hospitals'. Hueiyen Lanpao, August 12.

Hueiyen News Service. 2011a. '3 Dead as Blockade Turns Ugly on NH 3'. Hueiyen News Service, August 3.

-. 2011b. 'Kangpokpi ADC, 5 Other Offices Burned'. Hueiyen News Service, August 5.

—. 2011c. 'Minister Inspects Shops in Imphal Bazar Area, "Essentials commodities for 10 days in stock"'. Hueiyen News Service, October 8.

—. 2011d. 'Naga Bodies to Fight against SHDDC's Demand'. Hueiyen News Service, August 13.

—. 2011e. 'Sadar Hills Mark I-day with Protests'. Hueiyen News Service, August 17.

—. 2011f. 'UNC Should Not Oppose Sadar Hills: Kuki Peoples' Forum (KPF)'. Hueiyen News Service, August 10.

—. 2011g. 'Women Vendors Come out against Economic Blockade'. Hueiyen News Service, November 26.

—. 2012. 'ASEAN Car Rally: KSDC says "no", UNC “yes"'. Hueiyen News Service, December 12.

Husain, Zakir. 2011. 'Health of the National Rural Health Mission'. Economic and Political Weekly $46(4): 53-60$.

ICC and PWC. 2013. India's Northeast: Diversifying growth opportunities. Kolkata: Indian Chamber of Commerce/PricewaterhouseCoopers.

IDSA. 2014. Militant Groups in South Asia. New Delhi: Institute for Defence Studies and Analyses. Imphal Free Press. 2014. 'Apex court to Start Final Hearing on Fake Encounters within 4 Months'. Imphal Free Press, May 5. 
Imphal Municipal Council. 2014. Map ofImphal Municipality, Manipur:Indicating road, drainage and waterbodies, village boundary. 1:23,000. Imphal: Government of Manipur.

—. 2007. City Development Plan: Imphal. Imphal: Government of Manipur.

Irene, Salam. 2010. The Muslims of Manipur. New Delhi: Kalpaz Publications.

Jeffrey, Craig, Patricia Jeffrey, and Roger Jeffrey. 2004. 'Degrees without Freedom: The impact of formal education on Dalit young men in north India'. Development and Change 35 (5): 963-86.

-. 2005. 'When Schooling Fails Young Men: Education and low-caste politics in rural north India'. Contributions to Indian Sociology 39 (1): 1-38.

Jenkins, Rob. 1999. Democratic Politics and Economic Reform in India. Cambridge: Cambridge University Press.

Jilangamba, Yengkhom. 20o9. 'A Flicker in the Darkness. Tehelka 38 (6), September 26. http:// www.tehelka.com/a-flicker-in-the-darkness/.

- 2010a. 'Territorialities and Identities: North-Eastern Frontier of the British Indian Empire'. PhD diss., Centre for Historical Studies, Jawaharlal Nehru University, New Delhi.

—. 2010b. 'Ethnicity and Territoriality'. Himal Southasian 23 (7): 38-40.

-.2015. 'Beyond the Ethno-territorial Binary: Evidencing the hill and valley peoples in Manipur'. South Asia:Journal of South Asian Studies 38 (2): 276-89.

Kabui, Gangmumei. 1990a. 'Anglo-Manipuri War of 1891'. In History of Modern Manipur, 1826-1949, ed. Lal Dena, 48-69. New Delhi: Orbit.

—.199ob. 'Controversy over the Kabaw Valley'. In History of Modern Manipur, 1826-1949, ed. Lal Dena, 18-30. New Delhi: Orbit.

—. 1991. History of Manipur. New Delhi: National Publishing House.

Kangla Fort Board. 2009. Kangla: The ancient capital of Manipur. Imphal: Government of Manipur.

Karlsson, Bengt G. 2001. 'Indigenous Politics: Community formation and indigenous peoples' struggle for self-determination in Northeast India'. Identities Global Studies in Culture and Power 8 (1): 7-45.

- 2003. "Anthropology and the "Indigenous Slot": Claims to and debates about indigenous peoples' status in India'. Critique of Anthropology 23 (4): 403-23.

-. 2011. Unruly Hills: A political ecology of India's Northeast. New York: Berghahn Books.

Kaur, Ravinder. 2012. 'Nation's Two Bodies: Rethinking the idea of “new” India and its other'. Third World Quarterly 33 (4): 603-21.

Kermode, Michelle, Verity Longleng, Bangkim Chingsubam Singh, Kathryn Bowen, and Angela Rintoul. 2009. 'Killing Time with Enjoyment: A qualitative study of initiation into injecting drug use in Northeast India'. Substance Use and Misuse 44 (8): 1070-89.

Khangembam, Shanker. 2014a. 'Athoubashinggi Ningshing Numit (Martyrs Day) Observed at Cheiraoching, Imphal'. E-Pao. April 13. http://www.e-pao.net/epGallery.asp?id=1\&src=News_ Related/Encounter_Killing_Gallery/Athouba20140413_2. [Photo gallery]

- 2014b. 'ILP: Sit in protest by transgender people at Sagolband Salam Leikai'. E-Pao. August 22. http://e-pao.net/epGallery.asp?id=2\&src=News_Related/ILPS_Gallery/ILPTransgender20140822. [Photo gallery]

Kikon, Dolly. 2010. 'After 69 Days'. Himal Southasian 23 (7): 41-44.

- 2015. 'Fermenting Modernity: Putting akhuni on the nation's table in India'. South Asia: Journal of South Asian Studies 38 (2): 320-35.

King, Ross. 2011. Reading Bangkok. Singapore: NUS Press. 
Kipfer, Stefan, Parastou Saberi, and Thorben Wieditz. 2013. 'Henri Lefebvre: debates and controversies'. Progress in Human Geography 37 (1): 115-34.

Kipgen, Nehginpao. 2013. 'Politics of Ethnic Conflict in Manipur'. South Asia Research 33 (1):21-38.

Klauser, Francisco R. 2012. 'Interpretative Flexibility of the Event-City: Security, branding and urban entrepreneurialism at the European Football Championships 2008'. International Journal of Urban and Regional Research 36 (5): 1039-52.

Kohli, Atul. 2006. 'Politics of Economic Growth in India, 1980-2005: Part II: The 199os'. Economic and Political Weekly 41 (14): 1361-70.

-. 2012. Poverty Amid Plenty in the New India. Cambridge: Cambridge University Press.

Kom, Ch. Sekholal. 2011. 'Ethnic Politics in the Hills of Manipur'.Journal of Alternative Perspectives in the Social Sciences $3(1)$ : 147-67.

Kshetrimayum, Jogendro. 2009. 'Shooting the Sun: A study of death and protest in Manipur'. Economic and Political Weekly 44 (40): 48-54.

Kumar, Ashutosh. 2008. 'Dissonance between Economic Reforms and Democracy'. Economic and Political Weekly 43 (1): 54-60.

Kumar, Krishna. 2014. 'Rurality, Modernity, and Education'. Economic and Political Weekly 49 (22): 39-43.

Laithangbam, Iboyaima. 2013. 'Manipur Drug Case Going to CBI'. The Hindu, May 12.

Lefebvre, Henri. 1991. The Production of Space. Trans. Donald Nicholson-Smith. Cambridge, MA: Blackwell.

—. 1979/2003. The Urban Revolution. Trans. Robert Bononno. Minneapolis: University of Minnesota Press.

Legg, Stephen. 2005. 'Contesting and Surviving Memory: Space, nation, and nostalgia in Les Lieux de Mémoire'. Environment and Planning D: Society and Space 23 (4): 481-504.

Longkumer, Arkotong. 2010. Reform, Identity and Narratives of Belonging: The Heraka movement in Northeast India. New York: Bloomsbury Publishing.

Low, Kelvin E.Y. 2013. 'Sensing Cities: The politics of migrant sensescapes'. Social Identities 19 (2): 221-37.

Lowenthal, David. 1975. 'Past Time, Present Place: Landscape and memory'. Geographical Review $65(1): 1-36$.

Lund, Christian. 2006. 'Twilight Institutions: Public authority and local politics in Africa'. Development and Change 37 (4): 685-705.

—. 2011. 'Fragmented Sovereignty: Land reform and dispossession in Laos'. Journal of Peasant Studies 38 (4): 885-905.

Manipur Commerce and Industries Department. 2013. The Industrial and Investment Policy of Manipur, 2013. Imphal: Government of Manipur.

Manipur Directorate of Health Services. 2014. 'Health Manpower'. http://www.manipurhealthdirectorate.in/?page_id=239.

Manipur Directorate of Statistics. 2002. The Statistical Handbook of Manipur. Imphal: Government of Manipur.

-. 2007. Statistical Abstract Manipur 2007. Imphal: Government of Manipur.

Manipur Gazette. 1980. Approved Meitei Mayek, Public Law 1/2/78-SS/E. http://www.e-pao.net/ manipur/Manipur_Gazette_No_33_on_Meitei_Mayek.pdf.

Manipur Planning Department. 2012. Annual Plan (2012-13) and 12th Five Year Plan (2012-17) Proposals. Imphal: Government of Manipur.

-. 2013. Draft Annual Plan Proposals 2013-14. Imphal: Government of Manipur. 
-. 2014. New Land Use Policy of Manipur. Imphal: Government of Manipur.

—. 2015. 'Homepage', March 23. Planning Department Government of Manipur. http://planningmanipur.gov.in

Manipur Revenue Department. 2014. Manipur Land Revenue and Land Reforms Act. Imphal: Government of Manipur.

Marwah, Ved. 1995. Uncivil Wars: Pathology of terrorism in India. New Delhi: Indus.

Mathur, Shubh. 2012. 'Life and Death in the Borderlands: Indian sovereignty and military impunity'. Race and Class 54 (1): 33-49.

McCartney, Matthew. 2010. Political Economy, Growth and Liberalisation in India, 1991-2008. Abingdon/New York: Routledge.

McDuie-Ra, Duncan. 2009a. 'Fifty-year Disturbance: The armed forces special powers act and exceptionalism in a South Asian periphery'. Contemporary South Asia 17 (3): 255-70.

-. 2009b. 'Vision 2020 or Re-vision 1958: The contradictory politics of counter-insurgency in India's regional engagement'. Contemporary South Asia 17 (3): 313-30.

-. 2012a. Northeast Migrants in Delhi: Race, refuge and retail. Amsterdam: Amsterdam University Press.

—. 2012b. "Violence against Women in the Militarized Indian Frontier: Beyond "Indian Culture" in the Experiences of Ethnic Minority Women'. Violence against Women 18 (3): 322-45.

-. 2013. 'Flexible, Exotic, Unorganised: Frontier' women in Indian cities'. In The Global Political Economy of the Household in Asia, ed. Juanita Elias and Samanthi Gunawardana, 77-93. Basingstoke/New York: Palgrave Macmillan.

-. 2014a. 'Borders, Territory, and Ethnicity: Women and the Naga peace process'. In Border Politics: Social movements, collective identities, and globalization, ed. Nancy Naples and Jennifer Bickham Mendez, 95-119. New York: New York University Press.

—. 2014b. 'Harnessing Economic Potential in India's Northeast'. East Asia Forum Quarterly 6 (1): 30-31.

-. 2015. “Is India Racist?': Murder, migration, and Mary Kom'. South Asia:Journal of South Asian Studies 38 (2): 304-19.

MDONER. 2008a. North East Vision 2020, volume 1. New Delhi: Ministry of Development of North Eastern Region.

-. 2008b. North East Vision 2020, volume 2. New Delhi: Ministry of Development of North Eastern Region.

- 2008c. North East Vision 2020, volume 3. New Delhi: Ministry of Development of North Eastern Region.

-.2010. Final Report-Interim study to assess and evaluate the impact of NEIIPP 2007. New Delhi: Ministry of Development of North Eastern Region.

Mehrotra, Deepti Priya. 2009. Burning Bright: Irom Sharmila and the Struggle for Peace in Manipur. New Delhi: Penguin Books India.

MHFW (Ministry of Health and Family Welfare). 2009. Manipur: National health and family welfare survey. New Delhi: International Institute for Population Sciences.

Ministry of Commerce and Industry (India). 2014. Annual Report 2014-15. New Delhi: Ministry of Commerce and Industry.

Misri, Deepti. 2011. 'AAre You a Man?": Performing naked protest in India'. Signs 36 (3): 603-25.

Mitchell, Katharyne. 2003. 'Monuments, Memorials, and the Politics of Memory'. Urban Geography 24 (5): 442-59.

MSME. 2014. Annual Report 2012-13. New Delhi: Ministry of Micro, Small and Medium Enterprises. Murthy, Padmaja. 1999. 'The Gujral Doctrine and Beyond'. Strategic Analysis 23 (4): 639-52. 
Nayak, Dhanwanti. 2013. 'The Pitfalls of Privatisation of Higher Education'. Economic and Political Weekly 48 (5): 15-17.

Northeast Today. 2014. 'Northeast Consumer Awards Unveils to Top Brands'. Northeast Today. January 15.

NRHM. 2010. Regional Evaluation Team Report 2009-10. New Delhi: National Rural Health Mission. -. 2011. Regional Evaluation Team Report 2010-11. New Delhi: National Rural Health Mission.

-. 2012. Regional Evaluation Team Report 2011-12. New Delhi: National Rural Health Mission.

—. 2014. 'State-wise Information: Manipur'. 2 April. http://nrhm.gov.in/nrhm-in-state/statewise-information/manipur.html

O'Brien, William E. 2002. 'The Nature of Shifting Cultivation: Stories of harmony, degradation, and redemption'. Human Ecology 30 (4): 483-502.

Oinam, Bhagat. 2003. 'Patterns of Ethnic Conflict in the Northeast: A study on Manipur'. Economic and Political Weekly 38 (21): 2031-37.

Oza, Rupal. 2006. The Making of Neoliberal India: Nationalism, gender, and the paradoxes of globalization. Abingdon/New York: Routledge.

Parameswaran, Prashanth. 2014. 'Modi Unveils India's “Act East Policy” to ASEAN in Myanmar'. The Diplomat. November 17 .

Parratt, John. 2005. Wounded Land: Politics and identity in modern Manipur. New Delhi: Mittal.

Parratt, Saroj N.A. 1979/2012. 'Garib Niwaz: Wars and religious policy in $18^{\text {th }}$ century Manipur'. In Collected Papers on the History and Culture of Manipur, ed. Saroj N.A. Parratt and John Parratt, 70-8o. Imphal: Patriotic Writer's Forum.

-.1980. The Religion of Manipur:Beliefs, rituals, and historical development. Kolkata: Firma KLM.

-. 2005. The Court Chronicle of the Kings of Manipur: The Cheitharon Kumpapa: Original text, translation, and notes. New York: Routledge.

Parratt, Saroj N.A., and John Parratt. 1995/2012. 'Kabui Messiah: The Jadonong Movement in Manipur'. In Collected Papers on the History and Culture of Manipur, ed. Saroj N.A. Parratt and John Parratt, 81-102. Imphal: Patriotic Writer's Forum.

- 1997. The Pleasing of the Gods: Meitei Lai Haraoba. New Delhi: Vikas Publishing House.

—. 1999/2012. 'Hijam Irabot and the Radical Socialist Democratic Movement in Manipur'. In Collected Papers on the History and Culture of Manipur, ed. Saroj N.A. Parratt and John Parratt, 131-48. Imphal: Patriotic Writer's Forum.

—. 2001. 'The Second “Women's War" and the Emergence of Democratic Government in Manipur'. Modern Asian Studies 35 (4): 905-19.

Peoples Chronicle. 2014. 'Body for Conservation of Farmlands'. Peoples Chronicle, July 12.

Phanjoubam, Pradip. 2005. 'Manipur: Fractured land'. India International Centre Quarterly 32 $(2 / 3): 275-87$.

Piang, L. Lam Khan. 2014. 'Moving Backwards: Meitei's demand for Scheduled Tribe status'. Economic and Political Weekly 49 (15). http://www.epw.in/reports-states/moving-backwards. html.

Pine, Jason. 2012. The Art of Making Do in Naples. Minneapolis: University of Minnesota Press. Planning Commission India. 2007. Eleventh Five Year Plan (2007-12): Volume 2, social sector. New Delhi: Planning Commission, Government of India.

Pradhan, Kanhu Charan. 2012. Unacknowledged Urbanisation: The new census towns of India. New Delhi: Centre for Policy Research. 
Raj, Bullu. 2011. 'Sadar Hills Districthood Demand Committee Pleaded to King of Manipur, Leishemba Sanajaoba'.E-Pao, October 22.http://e-pao.net/epGallery.asp?id=1\&src=News_Related/Rally_Protest_Gallery/SadarKing20111022. [Photo gallery]

Raman, Bhuvaneswari. 2014. 'Patterns and Practices of Spatial Transformation in Non-metros: The case of Tiruchengode'. Economic and Political Weekly 49 (22): 47-52.

Ray, Sohini. 2009. 'Writing the Body: Cosmology, orthography, and fragments of modernity in Northeastern India'. Anthropological Quarterly 82 (1): 129-54.

Reeves, Madeleine. 2014. Border Work: Spatial lives of the state in rural Central Asia. Ithaca, NY: Cornell University Press.

Rehman, Teresa. 2009. 'Murder in Plain Sight'. Tehelka. August 8.

Reserve Bank of India. 2014. State Finances: A study of budgets: Part IV, fiscal position of state governments. New Delhi: Reserve Bank of India.

Riamei, Joseph. 2013. 'Contestations against Forces of Marginalisation: District Council and tribal resistance in Manipur'. Journal of Tribal Intellectual Collective India 1 (1): 55-57.

Robertson, Shanthi. 2011. 'Cash Cows, Backdoor Migrants, or Activist Citizens? International students, citizenship, and rights in Australia'. Ethnic and Racial Studies 34 (12): 2192-211.

Roy, Laifungbam D. 2014. 'Arbitrary Detention of 12 Persons from Office of JCILPS at Nongmeibung'. E-Pao, September 12.

Sacareau, Isabelle. 2007. 'Himalayan Hill Stations from the British Raj to Indian Tourism'. European Bulletin of Himalayan Research (31): 30-47.

Salam, Jeebanlata. 2014. 'Theft, Corruption, and Parental School Choice in Manipur'. Economic and Political Weekly 49 (12).

Samom, Anjulika Thingnam. 2010. 'Timeline of a Shutdown'. Himal Southasian 23 (7): 32-33.

Samom, Sobhapati. 2011. 'Migrants Outnumber Tribals in Manipur'. Silung, August 29.

Sangai Express. 2005. 'MEELAL Torches Central Library'. Sangai Express, April 14.

-. 2010. 'Kangla Still Dear to Assam Rifles'. Sangai Express, July 27.

—. 2011a. 'School Kids on the Streets: Human shields of a kind'. Sangai Express, October 13.

—. 2011b. 'SHDDC Pleads to Titular King'. Sangai Express, October 23.

—. 2012a. 'Centre Turns Down ILP Demand for Manipur'. Sangai Express, September 5 .

—.2012b. 'Molestation of Momoko: Naga bodies join condemnation'. Sangai Express, December 21.

—. 2013a. 'MEELAL organises language seminar'. Sangai Express, October 24.

—. 2013b. 'MEELAL Burns'. Sangai Express, December 21.

—. 2014a. 'Fitting Tributes Paid on Martyr's Day'. Sangai Express, April 14.

-.2014b. 'JCILPS'. Sangai Express, August 26.

SATP. 2014. 'Terrorist/Insurgent groups - Manipur'. South Asia Terrorism Portal. http://www. satp.org/satporgtp/countries/india/states/manipur/terrorist_outfits/index.html.

Saunders, Doug. 2010. Arrival City: How the largest migration in history is reshaping our world. London: William Heinemann.

Scott, James C. 2009. The Art of Not Being Governed:An anarchist history of Southeast Asia. New Haven, CT: Yale University Press.

Seigworth, Gregory, and Melissa Gregg. 2010. 'An Inventory of Shimmers'. In The Affect Theory Reader, ed. GregoryJ. Seigworth and Melissa Gregg, 1-28. Durham, NC: Duke University Press.

Selvaraj, Sakthivel, and Anup K. Karan. 2009. 'Deepening Health Insecurity in India: Evidence from national sample surveys since 1980s'. Economic and Political Weekly 44 (40): 55-60.

—. 2012. 'Why Publicly-Financed Health Insurance Schemes are Ineffective in Providing Financial Risk Protection'. Economic and Political Weekly 47 (11): 61-68. 
Sengupta, Mitu. 2009. 'Making the State Change Its Mind - The IMF, the World Bank and the politics of India's market reforms'. New Political Economy 14 (2): 181-210.

Sengupta, Somini, and Hari Kumar. 2005. 'Unending Civil Conflict Makes Life Grim in Indian State'. New York Times, September 2.

Seshadri, Villur Sundararajan. 2014. 'Time to Demonstrate an 'Act East' Policy'. The Hindu, November 13 .

Sharma, Aparajita. 2014. 'Irom Chanu Sharmila and the Movement against Armed Forces Special Powers Act (AFSPA)'. Space and Culture, India 1 (3): 18-26.

Sharma, Hanjabam Isworchandra. 2009. 'India's Look East Policy and Manipur's Economy: A critical scrutiny'. In Look East Policy and India's North East: Polemics and Perspectives, ed. Kishan Thingnam, 123-39. New Delhi: Concept Publishing.

Sharmila, Irom. 2014. Fragrance of Peace. New Delhi: Zubaan.

Shimray, Ungshungmi A. 2001. 'Ethnicity and Socio-political Assertion: The Manipur experience'. Economic and Political Weekly 36 (39): 3674-77.

Shin, Hyun Bang. 2012. 'Unequal Cities of Spectacle and Mega-events in China'. City 16 (6): 728-44. Sidaway, J.D. 2001. 'Iraq/Yugoslavia: banal geopolitics'. Antipode, 33(4): 601-o9.

Singh, Khwairakpam Premjit. 2012. 'Challenging Colonialism: Historical background of a female Zeliangrong rebel in the early Twentieth Century'. Indian Historical Review 39 (2): 273-91.

Singh, Kunj Bihari. 1963. 'Manipur Vaishnavism: A sociological interpretation'. Sociological Bulletin 12 (2): 66-72.

Singh, Longjam Nobinchandra. 2001. 'Ethnographic History of the Brahmins in Manipur'. In Glimpses on the Culture and Biology of the People of Northeast India., ed. Saratchandra Konsam, 48-58. New Delhi: Har Anand Publications.

Singh, N. Lokendra 1998. The Unquiet Valley: Society, Economy, and Politics of Manipur (1891-1950). New Delhi: Mittal Publications.

Singh, N. Somorendro. 2011. 'State of Education in Manipur'. Economic and Political Weekly 46 (23). Somorendra, Arambam. 2000. 'Manipuri Drama'. Indian Literature 44 (2): 32-39.

Sundar, Nandini. 2011. 'Interning Insurgent Populations: The buried histories of Indian democracy'. Economic \& Political Weekly 46 (6): 47-57.

Tandon, Suneera. 2013. 'Upscale Brands Train Sights on the Northeast after Establishing Themselves in Big Cities, Retailers Now Eye Demand in Unsaturated Markets'. Liveminit, February 18.

Tarapot, Phanjoubam. 2003. Bleeding Manipur. New Delhi: Har-Anand Publications.

Thangboi Zou, S. 2012. 'Emergent Micro-national Communities: The logic of Kuki-Chin armed struggle in Manipur'. Strategic Analysis 36 (2): 315-27.

Times of India. 2012. 'ASEAN Car Rally Will Pass through Manipur Smoothly: Gaikhangam'. Times of India, December 14.

Tohring, S.R. 2010. Violence and Identity in Northeast India: Naga-Kuki Conflict. New Delhi: Mittal Publications.

Tongbram, Dinesh, dir. 2014. $23^{\text {rd }}$ Century. Imphal: United Films Manipur. [Film]

UCM. 2005. Influx of Migrants into Manipur: A Threat to the Indigenous Ethnic People. Imphal: United Committee Manipur.

UGC. 2014. 'Total number of universities in the country as on 10.11.2014'. University Grants Commission. http://www.ugc.ac.in/oldpdf/alluniversity.pdf.

UNESCAP. 2013. 'Asian Highway Route Map'. United Nations Economic and Social Commission for Asia and the Pacific. http://www.unescap.org/resources/asian-highway-route-map. 
Vajpeyi, Ananya. 2009. 'Resenting the Indian State: For a new political practice in the Northeast'. In Beyond Counterinsurgency: Breaking the Impasse in Northeast India, ed. Sanjib Baruah, 25-48. New Delhi: Oxford University Press.

Van der Westhuizen, Janis. 2004. 'Marketing Malaysia as a Model Modern Muslim State: The significance of the $16^{\text {th }}$ Commonwealth Games'. Third World Quarterly 25 (7): 1277-91.

Van Schendel, Willem. 1992. "The Invention of the "Jummas": State formation and ethnicity in Southeastern Bangladesh'. Modern Asian Studies 26 (1): 95-128.

-. 2002. 'Geographies of Knowing, Geographies of Ignorance:Jumping scale in Southeast Asia'. Environment and Planning D 20 (6): 647-68.

- 2011. 'The Dangers of Belonging: Tribes, indigenous peoples and homelands in South Asia'. In The Politics of Belonging in India, ed. Daniel Rycroft and Sangeeta Dasgupta, 19-43. Abingdon/ New York: Routledge.

Vellakkal, Sukumar, and Shah Ebrahim. 2013. 'Publicly-Financed Health Insurance Schemes'. Economic and Political Weekly 48 (1): 24-27.

Xaxa, Virginius. 1999. 'Tribes as Indigenous People of India'. Economic and Political Weekly 34 $(51): 3589-95$.

Yahya, Faizal. 2003. 'India and Southeast Asia: Revisited'. Contemporary Southeast Asia 25 (1): 79-103.

Yambem, Sanamani. 1976. 'Nupi Lan: Manipur women's agitation, 1939'. Economic and Political Weekly 11 (8): 325-31.

Yeh, Emily T. 2013. Taming Tibet:Landscape Transformation and the Gift of Chinese Development. Ithaca, NY: Cornell University Press.

Yumnan, Jiten. 2014. 'An Introspection Manipur Paddy Land Conservation Bill 2014'. Sangai Express, July 28. 



\section{Index}

23rd Century (film), 93-94, 109, 111

Agamben, Giorgio 20-22

alcohol/alcohol bans 31,40-42, 62-63, 69-70, 186

All Manipur Road Transport and Motor

Worker's Union 99

All Manipur Students Union 110

All Naga Students Association of Manipur 97, 99

Appadurai, Arjun 26, 50

armed forces 18-20, 26, 30, 32, 40, 46, 49-53,

$57-58,60,62-63,65-68,70-74,76-88,90,93$,

95, 102-103, 105, 110-111, 114, 127, 132, 144

Armed Forces Special Powers Act (AFSPA)

$18-19,21,68,72,76-77,81,83,88-89,130,183$

Article 19(1) of the Indian Constitution 109, 114

Arunachal Pradesh 17, 123

Asian Highway 138, 141, 166, 184

Assam 17, 45-47, 93-94, 108, 123, 128-129, 139, $15^{1}$

Assam Rifles 18, 51, 53, 68, 70, 72, 76-78, 82, 88, $130,142,184$

Association of South East Asian Nations

(ASEAN) 32, 122, 128, 139-144

Athoubashinggi Ningshing Numit 86

Baishya, Amit 21-22

Bangladesh 15, 35, 46-47, 108, 136

Baruah, Sanjib 123

billboards 30, 59, 93, 119-120, 144, 150, 152, 170, 176-177

Bir Tikendrajit 83,86

Bir Tikendrajit Flyover (Imphal) 74-75

blockades 20, 28, 32, 49, 95-97, 100-102, 105-107, $114-115,143,151$

Bollens, Scott 5o, 96

British occupation of Manipur/British colonisation of Manipur 20, 27, 46-47, 53, 66, $76,81-84,94,98,108,110,113-114,174$

Brubaker, Rodgers 27

Central Industrial Security Force (CISF) 68

Central Reserve Police Force (CRPF) 68, 72-73

Chandel (Manipur) 105, 148

Chattopadhyay, Swati 131-132

Checkon (Imphal) 51, 74, 133, 135

Cheirao-ching (Imphal) 86-87, 89

China/Chinese 13, 23, 26, 46, 55, 61, 127, 136, 139, 155,173

Chingmeirong (Imphal) 51, 68, 152

Chongkham, Sanjit 72

church/churches (as markers of place) 14, 27, 51-52, 96, 104, 145, 148, 159-16o, 162, 173

cinema halls $13-14,58,134$

Commonwealth War Graves Commission 90

communism in Manipur 84-86
Cons, Jason 15-17, 22, 121

Conservation of Paddy Lands and Natural Resources Protection Committee (CPL) 172-173

Consumer Development and Public Distribution Department (Manipur) 101

Delhi 23, 27-28, 40, 59, 68, 74, 77, 82, 96, 99, 106, 110-111, 123-124, 127-128, 139, 141, 144, 150-151, $154-155,163,177$

development/economic development 15, 19, $23-25,29-30,32,48,54,56,66,73-76,79,93$, $103,123-128,133,137,139-140,144-146,148$, $151-153,172-173,180,187$

Devi, Thanjam Manorama 18, 72, 76

diaspora housing $55,73,167$

Directorate of Health Services 155

DM College (Imphal) 65, 174, 181

Dunn, Elizabeth 15-17, 22, 121

Eastern Bengal Frontier Regulation 110

Edufest 174-176

Federation of Regional Indigenous Society (FRIENDS) 110

ghosts/haunted areas $149,158,162$ graffiti $27,30,51-52,67,78,131-132$

Harvey, David 122

healthcare/health sector 16-17, 23-33, 144-156, 164-166, 179, 187

Heecham Yaicham Pat 83, 86

Heingang Kendra Loumi Lup 172

Herscher, Andrew 54

Hindi language/Hindi language ban 13-14, 34, $5^{8}, 120,130-131,134,142,175$

Hmar (community) 35

hospitals 32, 89, 109, 138, 145, 148-159, 161, 164, 173

Hunger Marchers (1965) 85

Ima Keithel (Imphal) 75, 138

Imphal City Development Plan 74

Indian Chamber of Commerce 124, 129

Inner Line Permit System (ILP) 32, 47, 81, 83, 93-95, 101, 108-115, 131, 165, 173, 184

Iroishemba (Imphal) 43, 51

Jilangamba, Yengkhom 45-46, 98

Joint Committee on the Inner Line Permit System (JCIPLS) 110-112 
Kangla Fort (Imphal) 39, 45-46, 51, 53, 58, 68, $76-77,81,83,87,89,93,140,176,184$

Kangleipak Communist Party 58, 130

Kekrupat (memorial) 20, 84, 87-88

Kolkata 133, 151, 163

Kom, Mary 47, 59-6o, 119

Korea/Korean 13, 61, 103, 106, 134, 136, 151, 173, 176

Kuki community 20, 35, 48-49, 51, 58, 70, 98, 99-101, 105-107, 141

Kuki Inpi Manipur 106

Kuki People's Forum 99

Kuki State Demand Committee (KSDC) 141, 143

lai/Lai Haraoba 65

laishang 27, 51-52, 65

Lamphelpat (Imphal) 14, 58

Langol 51, 145-146, 148, 156-162, 171

Lefebvre, Henri 16, 29-30

Look East Policy 23, 121, 125, 127, 133, 138, 150, 166

Lund, Christian 22-23

Majorkhul (Imphal) $5^{2}$

Manipur (Hill Areas) Autonomous District Council Act 96-97

Manipur Commandos 69, 72

Manipur Conservation of Paddy Land Bill 172

Manipur Film Development Corporation 74, 93,148

Manipur Government 18, 20, 33-34, 59, 67-69, $74,77,89,96-100,106,112,126,130,137,141$, $154,162,164-165,172$

Manipur Land Revenue and Land Reforms Act 172

Manipur police/state police $60,62,68-70,75$, $97,101,104,106,113,119,127,137,150,180$, 183-185

Manipur Rifles 58, 85, 148

Manipur State Land Use Board 171

Manipur Students Federation 165

Manipur University 148, 173, 178-179

Manipuri diaspora 15, 46, 55, 73, 121, 130, 167, 174

Mantipukrhi (Imphal) 77

Mao Gate (Manipur) 20, 89, 96-98, 100, 104, 106

Mapal Kangjeibung (Imphal) 83, 133

Marwah, Ved 85

Meetei Erol Eyek Loinashillon Apunba Lup, Kangleipak (MEELAL) 129-131

Meghalaya 17, 47, 108, 110, 119, 151

Meira Paibis 18, 21, 62, 76-78, 81-82, 86, 97, 110, 184

Meitei (community) 14, 20, 26, 28, 32, 34-35, $39-42,45-52,58,62-63,65,74-76,78-79,82$, $84,86-88,95-98,100-101,103,105-106,108$, $114,131-132,134,142,157,169$

Meitei Mayek 32, 120-121, 129-132, 144, 183 memorials 15, 20, 30, 32, 66-67, 78, 80-91, 101, $114,121,181,186$
Ministry of Development for North East Region (MDONER) 59, 123-128

Mizoram 17, 26, 35, 94, 110, 149, 154, 156

Modi, Narendra 127

'Momoko incident'/Momoko Khangembam 105-107

Moreh (Manipur) 133, 136, 141, 143, 149

mosque 27, 51-52, 90

Muivah, Thuingaleng 20, 69-97, 104

Myanmar 13-15, 23, 26, 32, 35, 45-47, 55, 61, 81, $83,85,96,98,101,106,119,124,127-128,133$, $136,139,143-144,146,149-151,166,173-174$, 184-185

Naga (community) 20, 28, 35, 48-49, 51-52, 58 , $70,87,96-102,105-107,128,142,148,158,163$

Naga Mothers Association 97

Naga People's Association 99

Naga Women's Union 97

Nagaland 17, 26, 35, 89, 94, 96-97, 110, 149, 151, 154,156

Nagaram (Imphal) 51, 102-105

National Games/National Games village 58-59, $75,140,145,148,158$

National Rural Health Mission 147-148, 155

National Socialist Council of Nagaland IsakMuivah (NSCN-IM) 20, 84, 87, 96, 105-106 neoliberalism/liberalisation in India 16-17, 25, $33,120,122-128,131,138,144-148,153-154,161$, $181,186-187$

Nepal 15, 35, 47, 108

Nepali (community) see non-Manipuri

New Land Use Policy 172

non-Manipuris (mayang) 35, 48, 52-53, 65, 81, 93, 95, 101, 107-108, 110, 112-114

North East Council (NEC) 59, 123, 145, 154

North East Industrial and Investment Promotion Policy (NEIIPP) 125-126

North Eastern Development Finance Corporation (NEDFi) 126

North Eastern Region Vision 2020 (NEV2020) $125-126,128,133,138$

Nupi Lal (women's war) 78, 81-83, 87, 100

Nupi Lal Lamjel 82

Nupi Lal Ningshing Thouram 82

nurses/nursing 145, 154-155, 176

Paite (community) 35, $5^{8}$

Pangal (community) 35, 51, 75, 82, 90

Paona Bazaar (Imphal) 13, 51, 133-134

Patriot's Day 83-84

People's Liberation Army PLA 86-87

Pine, Jason 16

plural/pluralism $26-27,42,47-48,5^{0}, 5^{2}, 5^{8}, 63$, $95,99,102,105,186-187$

private education sector/private schools 16-17, $33,101,119,163-169,171,173-175,177-179,181$ 
protest/protestors $15,18,20-21,49,70,76-78$, 80-81, 84, 87-88, 94, 97-101, 104-107, 111-112, $115,130,165,173,179,181,183^{-186}$

Ragailong (Imphal) 52-53, 88 Ramachandran, Mullappally 111 Rashtriya Swasthya Bima Yojana (RSBY) 147, 154

remittances $15,54-55,63,73,155,169,177,180$

Sadar Hills (Manipur) 96, 98-101, 106, 141 Sadar Hills District Demand Committee SHDDC 98-10o

Samom, Anjulika Thingnam 98

Sanamahi/Sanamahism 34, 39, 46, 174

Sangaiprou (Imphal) 166-171, 173, 179, 181

Saunders, Doug 51

Scott, James C. 45

Senapati (Manipur) 96, 157

sensitive space $15-17,22,31,42,112,121,144,181$, 184,186

Shaeed Minar (Imphal) 83

Sharmila, Irom 88-89, 130

Sidaway, James 19

Sikkim 17-18

Singapore 26, 139, 143

Singh, Ibobi Okram 77, 82-83, 97, 110, 112, 140, 145

Singh, Jananeta Hijam Irabot (Irabot) 84-87, 183

Singh, Manmohan 34, 77, 139

Singjamei (Imphal) 68, 82-82, 184

Sixth Schedule of the Indian Constitution $26-27,33-34,48,96$

small cities/vernacular urbanism 25, 47

Soibam Leikai (Imphal) 151,156

Somorendra, Arambam 85

Southeast Asia 23, 32, 74, 113, 121, 125, 127-128, $138-140,143,150,166,172$

sovereignty $15-16,19,21-22,54,66-67,76,78,80$, $83-85,108,112,120-121,129,132,143-144,146$, $150,162,186-187$ sport/sport grounds/sportspeople 31, 39, 50, $5^{2}$, $58-60,63,104,136,158,170,174,186$

Takhellambam (Imphal) 88-89

Tamenglong (Manipur) 52, 148

Tarpan Katpa 88

teachers 130, 151, 163-165, 169, 171, 180-181

territoriality see territory

territory/territorial politics 20, 23, 25, 30, 32, 48-49, 58, 67, 78, 83-84, 88, 96, 98-100, 107, $114,123,131,141,143,150,160,180,186-187$

Thailand 61, 136, 139, 166, 173

Thangal Bazaar (Imphal) 51-52, 57, 69, 72, 84, 113

Thangal General 83, 86

transgender (community) 61, 115

Tripura 17, 47, 93, 129

Ukhrul (Manipur) 14, 49, 96-97, 102-103, 148, 163,181

underground groups (general) 13, 19, 30, 49, 51-53, 55, 57-58, 6o, 63, 66-67, 69-71, 78-79, $86,102-104,111-112,126,128,130,137,154$, $157-158,165,169$

United Committee Manipur 109

United Naga Council 97, 99, 142

United Nations Economic and Social Commission for Asia and the Pacific (UNESCAP) 138

University Grants Commission (UGC) 178

Vaiphei (community) 35, 132

Vajpeyi, Ananya 21

van Schendel, Willem 45

VDF Thasana (film) 70

Village Defence Force 69-70, 75, 137

Yaiskul Hiruhanba Leikai (Imphal) 39-42, 85 yumjao $5^{1,} 5^{6}$

Zomia 45 
